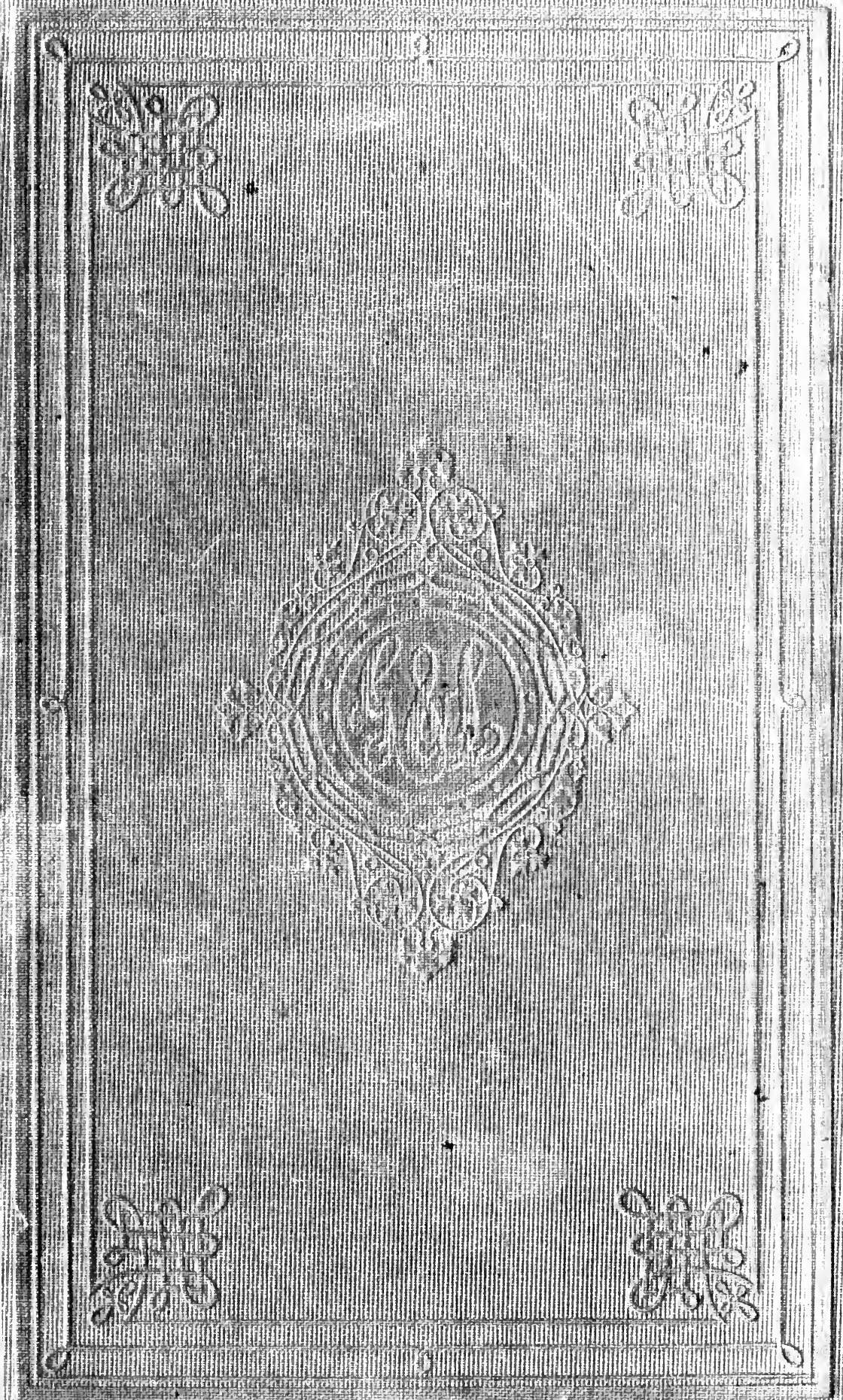




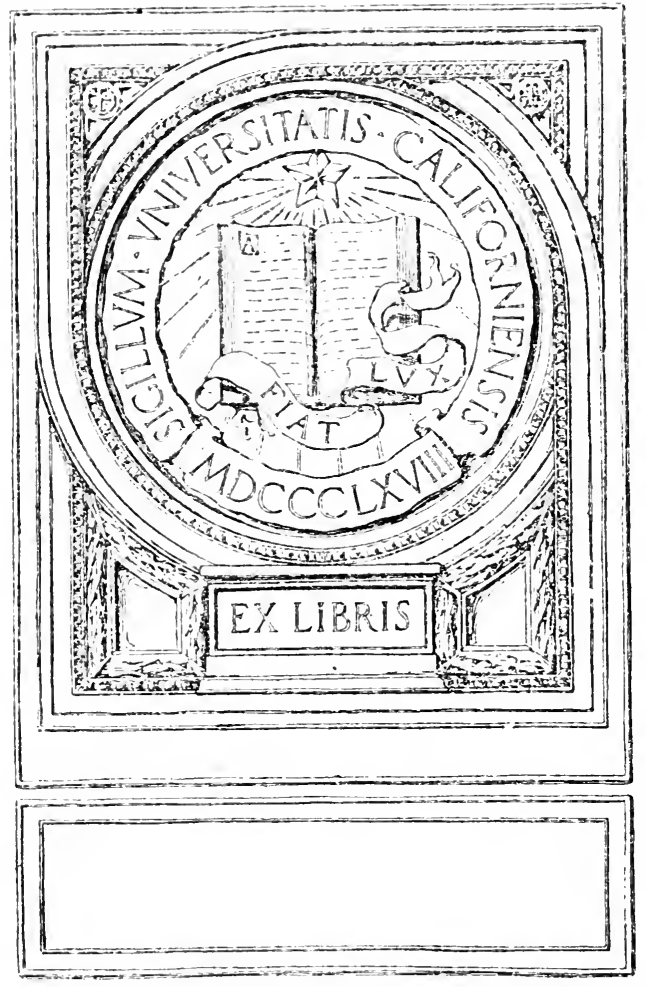





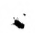



$\because, \because, \vdots, \vdots ;, \vdots \vdots ; \vdots \vdots \vdots \cdots$ 


$$
\begin{aligned}
& \text { most affectionates } \\
& \text { Mour tather } \\
& \text { Y.Eremt }
\end{aligned}
$$




\section{R. GRA N T}

A N D T H E

\section{OUNTAIN NESTORIA NS.}

B $Y$

\section{REV. THOMAS LAURIE,}

SURVIVING ASSOCIATE IN THAT MISSION.

"What mean ye to weep and to break my heart; for I am ready not to be bound only, but also to die at Jerusalem for the name of the Lord Jesus." - Acts 21 : 13.

W I T H

PORTRAIT, MAP OF THE COUNTRY, ILLUSTRATIONS, ETC.

\section{BOSTON:}

\section{GOUI,D A.ND LINCOLN,}

59 WA 8 HINGTON STRETT.

1853. 
Entered according to Act of Congress, in the year 1853, hy GOULD \& L I N COLN,

In the Clerk's Office of the District Court of the District of Massachusetis.

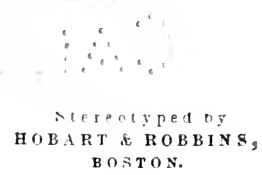

PRINTED BY FEO. C. RAND, CORNHILL 
(2) 10

\title{
MISSIONARIES OF CHRIST
}

\author{
IN WESTERN ASIA
}

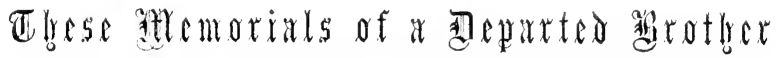 ARE AFEECTIONATELY DEDICATED,}

BY ONE EVER GRATEFUL FOR THE YEARS HE SPENT AMONG THEM, AND REJOICING THUS TO LABOR WITH THEM STILL IN A CAUSE HE CAN NEVER CEASE TO LOVE. 


\section{NOTE.}

IN the Oriental names that occur in the following pages,

$i$ has generally the sound of $e e$, as in Ashitha and Serspidho.

$\hat{u}$ has uniformly the sound of $o o$.

a represents the Arabic Ayin, as in Baad; and

$k h$ stands for the rough, guttural $h$ of the Shemitish languages.

oo sometimes occurs instead of $\hat{u}$, partly through inadvertence, but mostly in deference to others who have established the orthography of such names as Yoosuf, Oroomiah, \&c. The pronunciation of the last is $\hat{\mathrm{U}}$ rmy, both in Mosul and Tyary.

If any complain of the various modes in which different writers spell the same names, they are referred to $\mathrm{Mr}$. Layard, who justly observes, in a note page 370, of his "Babylon and Nineveh," - "The difficulty of getting a correct name, either of a person or place, in Kûdistan, is very great. The same name is pronounced in a variety of ways, and is subject to all manner of additions and contractions, so that travellers can scarcely avoid falling into frequent errors." 


\section{P REF A C E.}

Every one familiar with the history of the American Board of Commissioners for Foreign Missions must have noticed how few memoirs we have of its missionaries. Ont of more than one thousand labovers whom it has sent into the field during a period of more than forty years, many of whom have passed away to their final reward, there are, setting aside some excellent biographies of missionary women, extended nutices of but six, - namely, Levi Parsons, Pliny Fisk, Gordon IIall, David Abeel, Samuel Munson and Henry Lyman, - while of its many excellent missionary-physieians we have not a single biography.

That this want has been felt, at least in the case of I)r. Grant, appears from the small memoir published in 1847. Of this workvery excellent so fir as it went - the writer would say, in the language of Dr. Perkins, " The imperfect menoir which appeared a few years ago only made me more anxious that a more full and suitable record of his eminent worth, devoted life, and arduous labors, should be given to the world.' But, desirous as he was that this should he done, he would never have thought of doing it himself, but for a request from Mir. S. H. Grant to prepare a brief memorial of his father. The vain effort to compress the sulject into the few pages allowed him at that time led him to arrange the ficts with which he was familiar, that so much raluable material might not be lost: and 
the result of a year's labor, during the intervals of more pressing duties, now lies before the reader.

1t has been pleasint to the writer to live orer again the happy hours once spent with those now, as we trust, before the throne, and trace out the results of their afilictions, not only in their own meetness for hearen, hut also in the blessings still descending on the scene of their sufferings.

In the preparation of the work, many letters have been quoted only in part, and the journals of Dr. Grant have been much abbreviated ; but, as he expressed a regret that his writings were so verbose, and intended, in case he published again, to subject every sentence to the most rigid condensation, it was felt to be a sacred duty to carry out his wishes in the manner which would have been most agreeable to him were he still alive.

The map has been prepared mostly from original materials collected by Dr. Grant and his associates. That by Mr. Layard has also been consulted. Great pains have been taken, and no expense spured, to render it an important addition to our geographical knowledge of that region.

In conclusion, the writer would express his obligations to the former associates of Dr. Grant in Oroomiah, for the letters they hare kindly furnished him ; to his eldest son, and also to the widow and brother of Dr. A. Smith, for similar favors; to Dr. Anderson, for the free access he has granted to the library of the Board and importint manuscripts: and gladly would he make more specific mention of those friends to whose judicious suggestions the work is indebted for valuable corrections and improvements.

West Roxbury, MAY, 1853. 


\section{洯ist of allustrations.}

I. PORTRAit OF DR. GRANT, (Frontispiece).

The portrait is copied from a very eorrect daguerreotype likeness, taken in 1841 ; and the autograph was penned during his last sickness, at the close of the last letter he ever wrote. - (See p. 394.)

II. MAP OF THE NESTORIAN COUNTRY AND REGION ADJACENT.

III. VIEW OF TREBIZNAI, . . . . . . . . . . . . . . 40

This is a walled eity, though the wall does not appear in the view. The residences of the Missionaries are on the rising ground, just above the consulates, which may be distinguished by the flags. The road to Erzrûm lies up the valley to the right. High mountains rise all around behind the hill represented in the engraving, appearing to the traveller, as he approaches from the sea, like a lofty wall, enclosing the paradise below. Their snowy summits are, for the most part, wrapped in elouds.

IV. VIEW of ERZR $\hat{L} H, \ldots \ldots \ldots \ldots \ldots \ldots \ldots$

In the foreground appears a Bazaar, with traders seated here and there in the Dikkans. The columns at the end of the street are the minarets of an ancient mosque, and eontrast favorably with the clumsier modern structures of the same kind round about. The pyramid behind the wall to the right is a mansoleum, in the style of the tomb of Cains Cestins, at Rome, such as is often scen in the ancient eities of Asia Minor.

I. YERUEES, . . . . . . . . . . . . . . . 120

This is the dress generally worn in their villages near Mosul.

II. THE ZAB AHONG THE MOCNTAINS, ........... 142

This is a view of the river between Bedyalatha and the Berzawa, as described on p. 143.

VII. BRIDGE IN TYARY, . . . . . . . . . . . . 252

The weight of the centre-piece, in one instance, as measured by Dr. Smith, about ninety feet from pier to pier, is balanced by stones, piled 
on the opposite ends of the pices nearest the shore, as seen on the left. The passage of such struetures is diffienlt, at the best; and we need not wonder that Dr. Grant was obliged to eross one in the manner described on p. 264 , when it was old and out of repair.

VII. SPECLENS OF SYRIIO WRITING, . . . . . . . . 267

The cipher above the two lines is used at the beginning of every letter or document, and consists of the name of God, as it occurs in Ps. $68: 4$, with a symbol of the Trinity over it.

iX. THE SEAL OF YAK SHIVON (actual size), ......... . . 267

This is impressed in ink, just as here represented. The curious in such matters may find in it no less than thirteen crosses.

X. ANCIENT SELL FHOH NINEVEH, . . . . . . . . 290

This was purchased by M. Botta from an Arab, who found it on the surface of an ancient mound. after a rain.

XI. NESTORIANS FRON JeLU, . . . . . . . . . . . . . 302

This is the general dress of the mountaineers, though in Tyary they wear a conieal hat, and another coat without sleeves is often worn over the dress here represented. As to the ability of the women to carry burdens, see p. 147 .

XII. HOLSE IN TYART, . . . . . . . . . . . . . 310

The men in the foreground wear the hat referred to p. 336. The honse is one of the better class. In winter the lower story is used, and in summer the upper one is not too open for coinfort. The walls are adorned with the hurns of the mountain goat.

XII. MOSLL, AS SEEN FROM NINETEH, . . . . . . . . . 352

The mound and village of Nebbi Yunts are directly in front. The low mounds extending thence to the right are the remains of a part of the wall of Ninereh. The extreme south-east corner of Knyunjik is just risible in the edge of the plate.

On the left of the village, the Serai (or palace, - it comprises the barracks also) rises on the bank of the Tigris, below the eity. The bridge is hidden by the mosque of Nebbi Iunnus, and directly orer the latter rises the highest minaret in Mosul. It is built of briek, and belongs to a mosque, whieh was once a Christian church. It leans a little to one side, and is the most conspicuous object in the city. The house oceupied by Ir. Grant, and afterwards by Mr. Layard, stands on the high ground seen beyour Nebbi Yunus to the right. In the foreground, eattle are loarled, as deseribed on p. 234. 


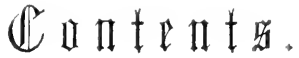

\section{CHAPTER I.}

PARENTAGE - EARLY LIFE - HONE TRAINING - EDUCATION - MARRIAGE - BRAINTRIM - CHRISTIAN ACTIVITY - BEREAVEMENT - UTICA - USEFULNESS THERE, . . . . . . . . . . . . . . 13

\section{CHAPTER II.}

DECISION TO BE A MISSIONARY - LETTERS - MISSIONARY TRAINING OF MRS. J. S. G. - SECOND MARRIAGE-EMBARKATION, . . . . 24

\section{CHAPTER III.}

SMYRNA - CONSTANTINOPLE - VOYAGE TO TREBIZOND - JOURNEY TO PERSIA - MEETING WITH MR. PERKINS - PASS OF DAHAR - FORTIFIED CAMP 一 TABRIZ, . . . . . . . . . . . . . . 36

\section{CHAPTER IV.}

THE NESTORIANS - ORIGIN OF THEIR LHURCH - EARLY HISTORY AND MISSIONARY ENTERPRISE - LATER HISTORY - DR. GRANT'S THEORY OF THEIR JEWISH ORIGIN, . . . . . . . . . . . . . 47

\section{CHAPTER V.}

ARRIVAL AT OROOMLAH - MISSIONARY PHYSICIANS - CHOLERA - LABORS

AND LETTERS OF DR. GRANT - LOOTEE - LABORS OF MRS. GRANT, 59

\section{CHAPTER VI.}

INTEREST IN THE MOUNTAINS - CORRESPONDENCE WITII COL. SHEIL AND DR. RIACH - SCHULTZ - FAILURE OF HEALTH - DEATH OF MRS. GRANT - Politics of kURdistan, . . . . . . . . . . . . 87 


\section{CHAP'TER VII.}

JOURNEY TO MESOPOTAMIA AND ASSYRIA - SALMAS - DISAPPOINTMENT CONSTANTINOPLE - ERZRUM - DIARBEKR AND ANARCHY - MARDIN SICKNESS - MOBS, AND NARROW ESCAPE - MOSIL - LETTERS - YEZIDEES - har MATTAI - AKRA - GEOGRAPHICAL DISCOVERIES, • • . 106

\section{CHAPTER VIII.}

FIRST JOURNEY IN THE MOCNTAINS - DUREE - VIEW FROM SLMMIT OF PASS - RECEPTION - LEZAN - SABBATH - SACRAMENT - ASHITHA PRIEST ABRAIAM - CHUMBA - MALEK - NESTORIAN WOMEX - NAZEE MOUNTAIN-ROADS - MAR SIIMON'S RESIDENCE - JULAMERK - BASH KALA, AND SICKNESS OF THE EMIR, . . . . . . . . . . . 124

\section{CHAPTER IX.}

MR. AINSWORTH - BEREA VENENT - LETTERS - SECOND JOURNEY THROUGH THE MOUNTAINS - HERTCSH - KURDS - ERZRUM - CONSTANTINOPLE VISIT TO AMERICA - CHILDREN — "THE LOST TRIBES" - RETURN TO THE EAST, . . . . . . . . . . . . . . . 151

\section{CHAPTER X.}

THIRD VISIT TO THE MOUNTAINS - REMINISCENCE - DERVISHES - SUMMARY JUSTICE - FAMINE - TRAVELLING IN THE EAST - FALSE ALARM ENCOUNTER WITII KCRDISH ROBBERS - VAN - TREACHERY OF KURDISH GUIDES - PATRIARCII AND DR. GRANT CROSS THE HIGHEST MOUNTAIN IN KURDISTAN - JELU - BASS - TEHOMA - SCRIPTURAL ASSOCIATIONS NARROW ESCAPE - DISCOVERY OF ANTIQUITIES - WLNE-DRINKING LABORS IN ASHITHA - NEWS OF DEATH OF MR. AND MRS. MITCHELL TREACHERY OF NESTORIAN GUIDES - THRILLING ADVENTURE IN SIGHT JOURNEY - ARABS - ARRIVAL AT MOSUL, . . . . . . . 170

\section{CHAPTER XI.}

JOURNEY OF MESSRS. HINSDALE AND MITCHELL - DIARBEKR - LETTER OF MR, MITCHELL - HIS SICKNESS AND DEATH - SICKNESS OF MRS. MITCHELL - ARAB INHUMANITY - HER DEATH - SICKNESS OF MR. AND MRS. HINSDALE - HEAT OF MOSUL - JACOBITES - MISSIONARY PROVIDENCE - JEWS - MOHAMMED PASHA - TURKISH OPPRESSION - IETTERS OF M. BOTTA-TOUR AMONG MOUNTAINS NEAR MOSUL-MICHA- ATHANASILS, BISHOP OF MALABAR, . . . . . . . . . . . . 195 


\section{UHAPTER XII.}

JOURNEY TO OROOMIAH-YEZIDEES AND MELEK TATS-ERRIL-CIIURI ISHNESS OF KURDS - CHIEF OF RAVANDOOZ - SCENERY - THE TOWN OF RAVANDOOZ- PILLARS AT SIDEK AND KELI SHIN - USHNEI-DIFFICULTIES AND DELAYS, . . . . . . . . . . . . . 217

\section{CHAPTER XIII.}

FOURTH JOURNEY TIROUgh THE MOUNTAINS- ADVENTURE AMONG TIE NOMAD KURDS - KANDI KILEESEI - MINERAL SPRINGS - KURDISII INHOSPITALITY AND NURDERS - TRAVELS WITH TIIE ENIR-NESTORIANS OF TALL - CAMP IN TEHOMA - JOURNEY TO JELU - A NIGHT ON THE MOUNTAINS - NESTORLAN TELEGRAPI - BASS - BLOOD FEUD AND RECONCILITION - KURDISII LIFE IN CAMP - TEHOMA - AVALANCHES NESTORIAN COOKING - THOUGHTS ON PEACE - MEDICAL PRACTICE - A NARROW WAY - HEART OF TUE MOUNTAINS - HEIYO THE OUTLAW MOUNTAIN ROADS AND BRIDGES - LIFE IN ZOZAN - RETURN TO ASHITHA - POLITICS - HERTUSH CHIEF - MISSION-HOUSE - EMIR's PERMISSION TO BUILD - FAILURE OF EXPEDITION AGAINST AMADIA - SYRIAC DEEN OF REAL EState, . . . . . . . . . . . . . . 234

\section{CHAPTER XIV.}

VISIT OF MR. HINSDALE TO THE MOUNTAINS- CONFERENCE OF PAPISTS WITH MAR SHIMON - RETURN OF MAR YOOSUF TO OROOMIAH - VISIT OF DR. GRANT TO JULAMERK - A SUNLESS WINTER - INTERTIEW WITH THE EMIR - KURDISII LADIES - BANDITTI - THEIR WAYS AND MEANS RETURN TO MOSUL - DEATII OF MR. IIINEDALE - PLAN TO ASSASSINATE DR. GRANT - HIGH-CHURCII OPPONENT - HIS OWN STATEMENTS - HOW REGARDED BY OTHER EPISCOPALIANS -- HIS POLITICAL INFLUENCE, . 268

\section{CIIAPER XV.}

PIFTH VISIT TO THE MOUNTAINS - MUD VILLAGE - KIIORSARAD AND M. BOTTA - AIN SIFNEH AND YEZIDEES - HEROINE OF BASTAWA - WOMAN IN MOSUL - NATURAL HISTORY - AMADIA - WIIAT POVERTY AND MISERY MEAN - PASS OVER MATINEH - SNOW - VALE OF BERWER - ZARNE - MULE-RIDING IN THE MOUNTAINS - PATRIARCHAL MANSION DR. GRANT'S CASTLE AS IT WAS-NESTORIAN FEAST - A NIGHT VISIT FROM KURDISH SPIES - A NESTORIAN STRIKE - HOW TO SUPPRESS IT ANOTHER NIGHT-ALARI - SYMPATIY WITH THE EGYPTIANS - FEROCITY OF THE NESTORIANS - APPROACH OF THE STORM, . . . . . . 288 


\section{CHAPTER XVI.}

VISIT TO BADIR KHAN BEY - FIERCENESS OF MOUNTAINEERS - KESTA ANTIQUITIES - KALA KUMRI - THE HABOR - A KURDISII " CUISINE" -DR. GRANT'S COMNISSARIAT - A SABBATH IN ZACHO - RULE OF BADIR KHAN BEY - JEZIRA - FORTS IN MOUNTAIN PASS - DERGULEII THE ASSEMBLED CHIEFS - ORIGIN OF TIE WAR - BADIR KHAN BEY'S PRONISE TO DR. GRANT - HIS CHARACTER - SUMMER QUARTERS - A GEORGIAN - IIOW A KURDISH CIIIEF SPENDS THE DAY - TRADITION OF THE ARK - SHAKH - RETURN TO ASHITHA, . . . . . . . 32S

\section{CHAPTER XVII.}

COMMENCEMENT OF TIE STORM - VISIT TO MALEK BERKHO - SLAUGHTER IN DISS - RETURN OF DR. GRANT TO MOSUL - MASSACRE AT CHCMBA, AT MAR SAWA AND SERSPIDHO-DESTITCTION AFTER THE SLAUGITER - MAR SHIMON FLEES TO MOSUL - MISERY OF THE CAPTIVES - SUFFERINGS OF THE REMNANT - INSURRECTION IN ASHITHA BRINGS DESTRUCTION ON THE WHOLE VALLEY - BUTCHERY AT LEZAN - LAYARD'S ACCOUNT - ATROCITIES OF ZEINER BEY - FALL OF TEHONA-STATISTICS, 344

\section{CHAPTER XVIII.}

COURTESY BETWEEN MISSIONARY SOCIETIES - LETTERS OF DR. GRANT - HIS PROPOSITION - LATORS ANONG TIIE JACOBITES - MICHA - MR. BADGER - DR. GR.NT ExONERATES HIM FROM A FALSE CHARgE - MLAR SHIMON - EYIL OVERRLLED FOR GOOD - BIBLE CLASS - ANOTIER BEREAVENENT - REBUKE FOR SYMPATHY - DEATH OF PASIIA - HOSPITALITY TO REFUGEES - DEATHS NONG THEM - DHFFICCLTY ABOUT BURIAL-DR. A. SMITH - HIS JOURNEY - CHARACTERISTICS - HIS LETTER ON "ORGANIZATION," . . . . . . . . . . . . . . . . . . . . . . . . . .

\section{CHAPTER XIX.}

TIAY TO RETURN TO AMERICA - LETTERS - SICKNESS AND DEATH - FUNERAL - TROUBLE ABOUT TONB-STONE- POSTHUMOUS USEFULNESS - LETTERS FROM MR. PERKINS AND DR. WRIGHT - ADDRESS OF NESTORIAN PUPIL TESTIMIONY OF MR. BADGER - LETTERS FRON HON. MR. LAYARD AND REV. D. W. MARSH - NOTICE OF MISSION AFTER DEATH OF DR. GRANT DEATH OF CHILD OF MIS. HINSDALE - LETTERS OF HICHA - SUCCESSORS OF DR. GRANT AT IOSUL, AND IN THE JOUNTAINS- FATE OF OPPOSERS - CONClusion, . . . . . . . . . . . . . . . . 30 
gdo 


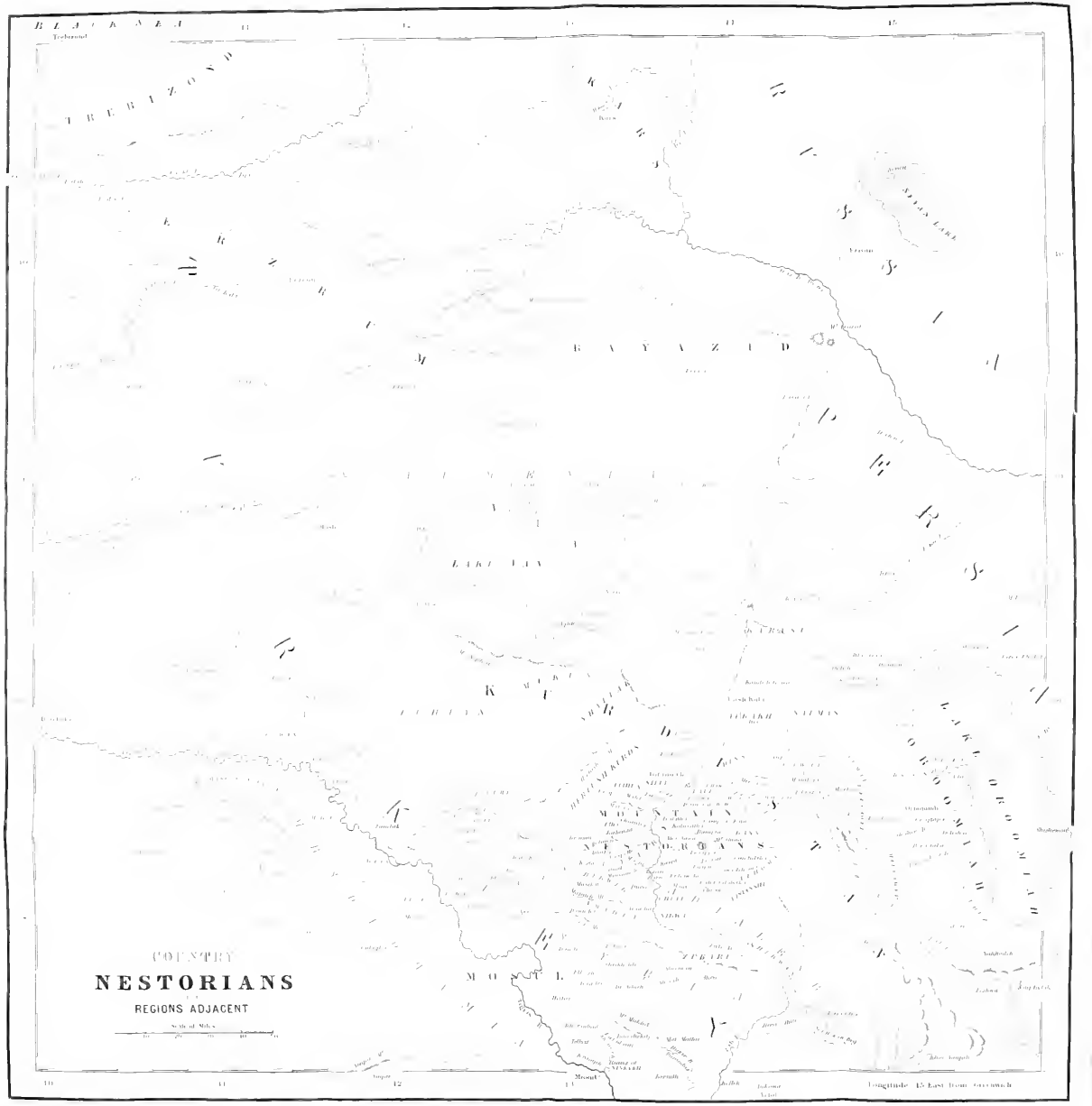




\section{H A P T E R I.}

PARENTAGE - EARLY LIFE - HOME TRAINING - EDUCATION - MARRIAGE BRAINTRIM - CHRISTIAN ACTIVITY - BEREAVEIENT - UTICA - USEFULNESS THERE.

Is the town of Marshall, N. Y., near the top of an eminence still known as "Grant's Hill," an old yellow house, two stories high, looks out on dark-green woods, sunny slopes and fruitful farms. Here, on the 17th of August, 1807, Dr. Asahel Grant was born. The place is changed since then. Strangers occupy the old homestead, and few of the neighbor's remember the subject of this narrative.

He was the second son of William and Rachel Grant; in whom God had not only provided pious parents for the future missionary, but such as, converted in early life, had grown up with tastes and habits sanctified by a spiritual faith. They were chosen, too, from one of the most favored nurseries of New England piety, - Litchfield county, Conn., - a region noted for pure revivals, and for the sterling, intelligent type of its piety. There Bellamy lived and labored. There was the mission school, in Cornwall. From that county went out Samuel J. Mills and others, to bless the world. It furnished, also, one of the two missionaries who were afterwards permitted to share the labors of Dr. Grant in Kurdistan.

His parents were eminently given to prayer; and that, not merely for themselves or neighbors, but for the world. The kingdom of Christ held a prominent place in their supplications. 


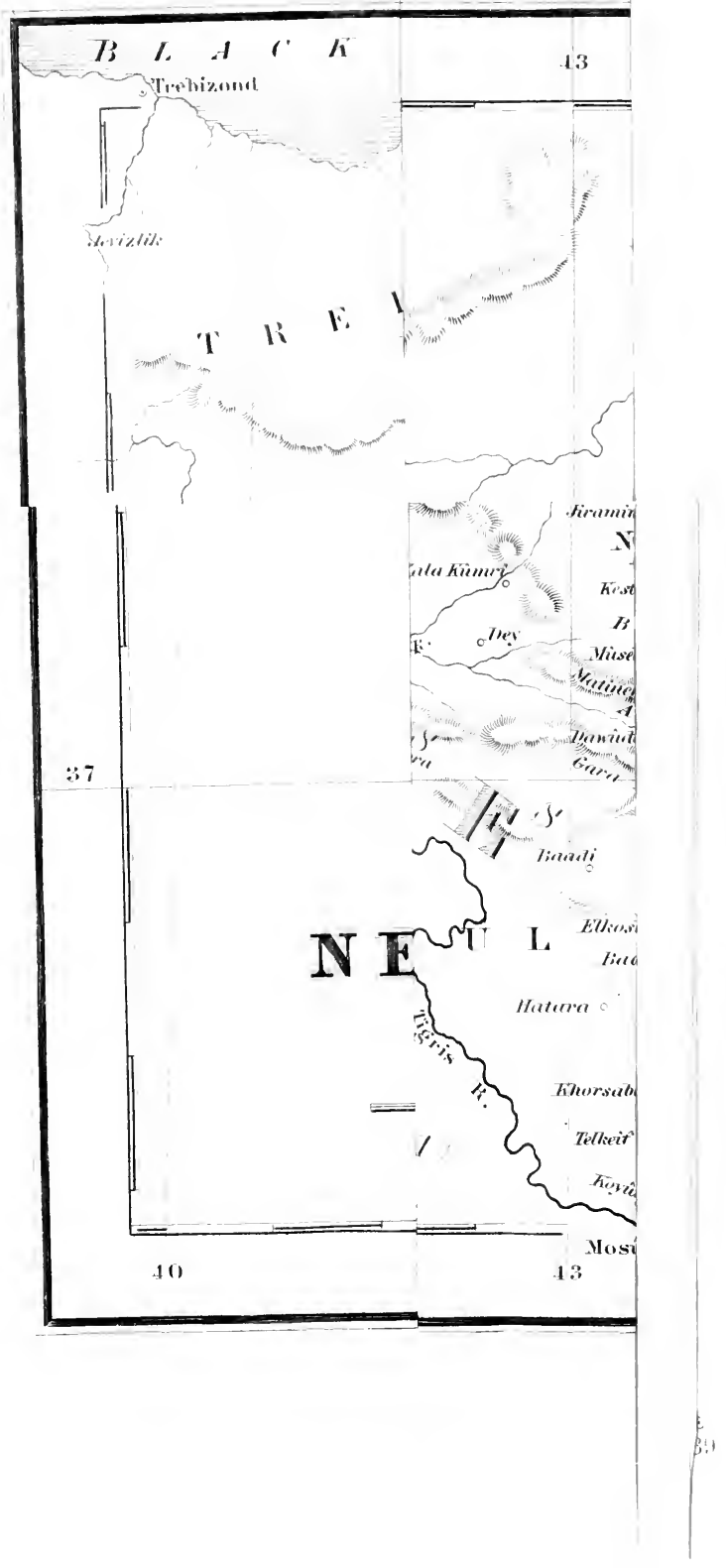




\section{H A P T E R I.}

PARENTAGE - EARLY LIFE - HONE TRAINING - EDUCATION - MARRIAGE BRAINTRIM - CHRISTIAN ACTIVITY - BEREAVEMENT - UTICA - USEFULNESS THERE.

Is the town of Marshall, N. Y., near the top of an eminence still known as "Grant's Hill," an old yellow house, two stories high, looks out on dark-green woods, sunny slopes and fruitful farms. Here, on the 17th of Angust, 1807, Dr. Asahel Grant was born. The place is changed since then. Strangers occupy the old homestead, and few of the neighbors remember the subject of this narrative.

He was the second son of Williain and Rachel Grant; in whom God had not only provided pious parents for the future missionary, but such as, converted in early life, had grown up with tastes and habits sanctified by a spiritual faith. They were chosen, too, from one of the most favored nurseries of New England piety, - Litchfield county, Conn., - a region noted for pure revivals, and for the sterling, intelligent type of its piety. There Bellamy lived and labored. There was the mission school, in Cornwall. From that county went out Samuel J. Mills and others, to bless the world. It furnished, also, one of the two missionaries who were afterwards permitted to share the labors of Dr. Grant in Kurdistan.

His parents were eminently given to prayer; and that, not merely for themselves or neighbors, but for the world. The kingdom of Christ held a prominent place in their supplications. 
It is said that his father never failed to remember his children at the family altar, and his mother often took them with her to her closet, to plead with them and for them before God.

It reveals something of the character of these prayers, ard the lives of those who offered them, that before the father died all, save one, of his children were hopefully converted, while the mother was permitted to live to rejoice in hope for them all. Such were the parents of Dr. Grant; and we should fail to detect the more important influences that gave direction to his character, if we do not look in on those seasons of family devotion in the household of that pious farmer, and hear the mother speaking to her children of Eliot and Brainerd, and the Saviour who commanded them to preach his gospel to them that sit in darkness.

It deserves notice that the Rev. S. Kirkland, who had been a missionary to the Indians for forty years, died in the very town where Dr. Grant was born, while he was yet an infant in his cradle. What effect the memory of that good man, as dwelt on by his mother in his boyish years, may have had in deciding his future course, can never be known till we see the connections that bind together the kingdom of Christ in all ages in the light of heaven. Be that as it may, no one can read his letters to his mother, revealing ardent affection and esteem, unchanged to the very last, and not feel that it was no common impression in childhood that continued through all his changing career so fresh and clear to the end. Just before his death, he stated that the early religious impressions made by his godly mother had followed him in all his wanderings througt life. Courage, then, Christian mother! you deem your sphere of action humble and obscure, but you may be moulding a character that shall be felt around the globe and down through distant ages.

Mere piety, however, and prayerfulness, are not the only requisites of a good parent. A judicious method of discipline, firmly carried through, is essential in the training of children 
who are to be useful in after life; and, therefore, we are not surprised to learn that the parents of Dr. Grant were found faithful in this, also. When he was about two years old, his mother had a severe struggle to secure his obedience; but, severe though it was, she did not stop till he was subdued, - and a word, or even a look, from her afterwards, was enough.

His disposition was naturally very pleasant. He was remarkably obliging, even in childhood; and nowe that knew the man will forget the loveliness of this trait, that seemed to have been ripening from his earliest years.

He early manifested a preference for the medical profession. The money given him was carefully saved till he was about seven years of age; and before any of the family were aware, he had a drawer neatly fitted up as a niniature apothecary's shop. In this may be seen the bud of that decision and self-reliance that afterwards carried through greater enterprises alone and unaided.

His school life began in the district school-house, a mile from his father's house ; and, at ten years of age, he might be seen poring over his books, while others played. Nor were these mere story-books, but history and science were already his chosen themes. While engaged on the farm, he read many a volume fastened to the plough; and at the "nooning," when others slept, he was realing. Still, it would seem that his father did not do much to encourage this ardent thirst for knowledge, for he needed his help on the farm, and, perhaps, feared lest he might lose it. But his mother did all in her power to foster his love of books, for to her mind it was full of promise for the future.

Such good training at home was not thwarted by bad influences from without. He was far removed from the distracting sights and demoralizing habits of the city. His home was in the midst of an intelligent people, who loved the gospel, and there-. fore promoted elucation. The spirit of the devoted missionary 
who had laid his bones among them seemed to remain in the community; and their aratemy had, doubtless, other ant deeper connections with Kirkland than his name. There were libraries, to whose stores of information Dr. Grant had early access; and, no doubt, young men like-minded with himself; whose intercourse was mutually beneficial.

His temper was naturally quick, but at the age of twelve he had already attained that mastery of himself which many who begin later struggle for in vain. Impatience and fretfulness do not mar the pleasant recollections treasured up in the memories of his friends.

About this time occurs a noticeable link in the chain of providences fitting him for the future. His services were so valuable on the firm, that probably his father would never have consented to his leaving it, had not a severe wound from an axe in one of his feet so unfitted him for agricultural labor that he was allowed to gratify his oft-repeated desire to study medicine.

It must have been before this accident that he was in the habit of jumping on his father's colts, and riding about the pasture without saddle or bridle, despite all their efforts to throw him off; an early development of his characteristic fearlessness and tact. With a constitution invigorated by out-door exercise, and the simple habits of his early home, he now spent two or three terms at an academy, and one term at Hamilton College, in the study of chemistry.

When only sixteen, he taught a school with marked success, and with the dignity of riper years; and then continued hi: academical stulies, till he commenced the study of medicine with Dr. Hastings, of Clinton. That this last relation was a pleasant one, we may infer from his giving the name of his instructor to his eldest son. He also attended the usual lectures at Fairfield, and at Pittsfield, Massachusetts; and near the close of his 
studies spent a year with Dr. Douglass, then a noted surgeon in Utica.

Thus, while Dr. Grant was well trained as a physician, he did not enjoy the advantages of a liberal education. This he always felt to be a disadvantage, though his early habits of reading were never intermitted, when books were within his reach; and he himself would have warned impatient youth that, though it may seem a waste of time, yet a regular, thorough education is a real saving, in the better qualification it gives for doing good.

However amiable and moral, Dr. Grant was not yet a Christian. Like others at his age, he was gay, and fond of worldly amusement.s. But the prayers that for more than nineteen years had been ascending for him were now to be answered. It is to be regretted that we have no full record of his religious feelings at the time of his conversion. We want to know more of the beginning of a religious life whose subsequent development was so marked; but so much as we know makes it manifest that, not as some, desiring only happiness from Christ, and, therefore, never finding it, but as a simner deserving destruction, who conld neither save himself nor urge any claim on Christ for salvation, he cast himself on His merey, and found peace through faith. With the foundation of missionary character thus laid in a personal union to the Saviour, he increased in fitness for the work, by his diligent labors for the salvation of his late associates, joined to a great delight in the closet and in the word of Corl, - two things that at the very ends of the earth more than make up the loss of all earthly friends.

He joined the Presbyterian ehurch in Clinton, and it neer searce be adderl that henceforth he took a deep interest in the missionary work; for how can it be otherwise with one who loves the Saviour of the world, and lives for his glory?

One of his companions, who nost deeply sympathized with his new feelings, and was the more immediate means of the change, was Miss Electal \$. Loomir, of Tomington, Comecticut. Beau- 
tiful in porson, of an amiabls temper, haring well improved her advantages for an education, she was every way worthy of his ardent attachment. Her piety must have been deep and decided, and she herself possessed of no little weight of character, to exert the influence she did on the gay young physician. But he wis just the man to appreciate her excellence, and they were married when he was yet in his twentieth year. A union formel in such circumstances was likely to be happy, for their affetion, being largely imbued with love to Christ, was fitted to be permanent. A year afterwards he received his diploma, ant settled one hundred and thirty miles from Utica, in the rur:il village of Braintrim, just over the line of Pennsylvania, on the bauks of the beantiful Susquehanna. He evidently carried his religion with him, for he was chosen Ruling Elder in the little church.

During most of their residence here the church was without a pastor ; and it speaks well for the position Dr. Grant occupied as a Christian, that while there he read more sermons to the congregation on the Sabbath than he had the privilege of hearing preached. He neither belonged to those physicians whose business is so pressing during the hours devoted to public worship that they cannot attend, nor to those church-members whose presence in the sanctuary depends mainly on the degree of attraction in the pulpit, and who go to the prayer-meeting only when not likely to be called on to take a part. His piety wals not of that spongy character that is dry and hard sare as it abrorbs moisture firom withont, and then refuses to impart it exce; nurler preswie. It was like the forntain, ever filled from the fulness there is in Christ, and ever imparting what it had to others.

Gorl seems to have hat another object in placing him there. His duties as physician often led him to ford the river when the current almost carried away his horse; and when that had to les left behind and he could cross the swollen stream only in a 
ranoe, then he wats compelled to walk long distances over the hills, as though He who had called him to toil among the rugged defiles of Kurdistan took this method to prepare him for nis work.

His moral courage was so conspicuous, in sumounting the difficultios of his position here, as to lead a friend to write afterwards to the American Board, _ " If you have a field requiring great physical activity and moral courage, he is the man. If called to it, no fear but he will endure hardness as a good soldier of Jesus Christ." We need no records of their stay in Braintrim to assure us that two such congenial spirits were haply in the prosecution of every good work. But that happiness was short. The missionary needed to be prepared for future scenes by suffering as well as hardships; and his beloved Electa was taken from him, after four short years of delightful coöperation in efforts to do good. Hers seems to have been a missionary spirit; and, though not permitted to enter the field, who knows how much she did to prepare her husband for his future toils, so that, thongh dead, she still speaks in Mosul and Tyary, as well as in that quiet village on the Susquehamma! We have a glimpse, am! but a glimpse, of her gentle spirit, when on her death-bed, sueaking of the children she was so soon to leave, she says to her weeping huband, "The Lord will take care of them." Words repeated by him also, when he spoke of those same children, on his own death-bed, in a distant land. She left two sons, the oldest now the popular librarian of the New York Mercantile Library Association; and the other, then five months old, - a graduate of Kenyon College, in Ohio; both adorning a profession of devotion to the God of their fathers.

Four days after the beginning of her last sickness, her huband was prostrated with bilious fever, and his life trembled in the balance when she was carried to the grave. His mother, as soon as she heard of it, hastened to his bedside. Her daughter- 
in-law had boen dead some days when she arrived, and, after staying through some weeks of her son's convalescence, she kindly took his motherless bibe to her own home. Thanks to God for a mother's love! Iler child may leare her and set up another and a distant home, and yet, at the first news of affliction, the same hand that helped us in infancy, and the same voice that soothed our childish grief, hastens to comfort us, as kind and tender, and, if possible, nore gentle than before.

As soon as he was able, Dr. Grant settled up his affairs, and, with his oldest son, exchanged the scene of so much sorrow for the friendly shelter of his fither's roof. He suffered, but he did not complain. He felt that the dearest objects of earthly affection are lent but for a moment. And, as he found the greatest comfort in reviewing their mutual efforts to serve God, he deroted himself as never before to self-denying labor for Christ. He was led to look in on another world; but, instead of impatient desire to enter into rest, he consecrated himself afresh to the work of bringing others, throngh grace, to that glorious inheritance.

The preparatory discipline God designed for him in Braintrim was now completed, and in a few weeks he was led to settle in Utica, the last remove previons to entering on the great work before him. He here entered into partnership with an experienced physician, whose removal, some eighteen months after, left him a large and lucrative practice. Here, again, he took at once a decided stand as a Christian. He was erer in his place on the Sabbath, and took an active part in prayerneetings during the week. He was the prime mover in a plan to supply the poor with useful reading, and, in the words of a living witness, "as an active Christian layman, he had no superior in the city." He exerted himself in the most self-denying forms of Christian effort, snch as labors among the poor and the loatmen on the canal. So identified was he with these efforts, that he was known to many as "the friend of the poor," a title 
he shared in common with the late Dr. William Gordon, in our father-land. In his praetice he did not seek wealth, but usefulness, according to the command, - whether, therefore, ye eat or drink, or whatever ye do, do all to the glory of God.

In kind, assiduous attention to his patients, he was excelled by none. The poor preferred him. During the prevalence of the cholera in 1832, he was " in labors more abundant." Says his pastor, Dr. S.C. Aikin, "Never was a man more active than he in that time of suffering, till he himself was prostrated by the disease. I well remember the hour. It was in a house where all were sick, - the father and a lovely daughter in the agonies of death. Passing from room to room, I found him sitting by the kitehen fire, his head resting on his hands. I saw at once the disease was on him, and yet could searce persuade him to retire and take tare of himself. His compassion, no less than his fortitude and wonderful power of endurance, sometimes carried him too far. But he felt he was called to minister to the poor, and that no personal sacrifice must be spared."

Unlike those who are never ready to act till others are, he was always ready to go forward in doing good. He was active when others were stupid and lifeless; such an one as a pastor could safely lean on; and yet, with all his zeal, he showed great prudence and sound judgment. He had, withal, an uncommons facility at living peaceably with all men; and it is no siight evidence of this, that he secured the confidenee and estecm of his brother physicians, - a holy skill he never lost in any scenc of future labor. He showed great tact in approaching men, so as to disarm prejudice, and make a stranger feel at once that he was a friend; an impression subsequent intereourse never counteracted. He was one of the select few who ean do good, and deal faithfully, yet without giving offence. Though an uncompromising foe to Popery, he had the confidence of the Papists, beyond, perhaps, any other Protestant in Utica. Everz their friests recommended him as the best and most honest 
physician in the place, teaching us that love to those in error is compatible with the most steadfast attachment to the truth, and will do good when bitterness and bigotry only bar the road to usefulness.

It was some evidence of the estimation in which he was held by good men, that after only one year's residence in the place, he wals chosen elder in the First Presbyterian Church, though he was then only in his twenty-fourth year, and none of his associates had numbered less than forty. "Owing to his sense of unfitness and comparative youth," says his pastor, already quoted, "he was hardly persuaded to accept the office to which he was unanimously chosen; but the choice was judicious, and most fortunate for the church. He was both popular and useful ; though young, he was wise in council; and so consistent was his life, so devoted in visiting from house to house, so affectionate and yet faithful in instruction and admonition, that he soon secured the confidence, not only of the church, but of the impenitent also. However they found fault with some, all readily admitted that Dr. Grant was a true believer. The church was loth to part with him, for seldom is a church blessed with such an officer. Too many elders count their duty done, if now and then they attend a meeting of session; hut he regarded the office as involving the duty of being an example to the church, and coöperating with the pastor in active labor; in short, an investiture demanding the entire consecriation of time and talents to Christ."

He had such a winning way of conversing on religious subjeets, and his life added such foree to his words, that in revivals he was eminently useful. The secret of his usefulness was felt to be Christ dwelling in him. His pastor loved to see him in a meeting for inquirers, he was so still and solemm, so happy in meeting objections and removing difficulties.

As a teacher in the Sabbath-school, he was very faithful, and 
seldom absent; beloved by his class, as such a teacher might expect to be.

By rigorous system, he contrived to visit his patients without neglecting either the sanctuary or the Sabbath-school. His duties for the day were all arranged in the morning, and each fell naturally into its proper place, so that he did not need, like some, to neglect one duty, in order to perform another.

With all this, he was not appreciated by many as he would have been but for his retiring and unassuming manners.

Such was Dr. Grant in Utica, according to the testimony of those who knew him most intimately. In the next chapter we will view him in the more immediate preparation for his work. 


\section{CHAPTER II.}

DECISION TO BE A MISSIONARY - LETTERS - MISSIONARY TRAINING OF MRS. J. S. G. - SECOND MARRIAGE - EMBARKATION.

Oxe intimate with him at this time (Rev. J. B. Shaw) writes, "The Christianity of Dr. Grant is a determination to honor Christ in making the world better. With him, to serve Christ is to do good to the utmost extent and for the longest period. At one time he thought of going, disconnected with any society, to Singapore or China, there to employ his medical skill to the best advantage for Christ. With this enlarged benevolence was joined another quality that eminently fitted him for the post before him. By nature he was courageous, and piety transformed this into a Christian intrepidity that never knew fear in maintaining the right or doing good. His self-possession increased, as difficulties grew more appalling. His nerve was firmer, as danger grew more imminent." As we have seen, in the midst of a dreaded epidemic, he counted not his life dear to him, if only he might do good. Such characteristics led a friend to say that " one design of Providence in assembling the Board at Utica, in 1834, secmed to be to enlist Dr. Grant in the work; the part of the report relating to Persia touched a chord in his heart that never after ceased to vibrate."

But we will hear his own account of the matter, as given in his "Appeal to Pious Physicians," written after his arrival in Persia :

"A young physician, who had an extensive and increasing practice in one of our flourishing cities, had thought much of 
engaging in the work; but, as often as he considered the matter he dismissed it, under the plea that, much as laborers might be needed, yet there were so many obstacles in his way that he, at all events, could not go. Others were hetter qualified, and with far less to detain them at home, and they might go. But they did not, - the call was urgent, and what was to be done? He prayed over the subject, and resolved on a more thorough examination of personal duty. He took up his former excuses, one by one. He asked, "Can I do more at home or abroad for the conversion of the world. In this view, where am I most needed? Here I may relieve much suffering, and perhilps prolong some raluable lives. But, should I go, others could do it just as well, and I should not be missed. Abroad I may relieve one hundred-fold more of misery, - perhaps save the lives of missionaries of inestimable value to the cause, and that, too, when no one else will do it.

" "Here I have many opportunities of acting for Christ; but what are they, in comparison with those abroad, where I may be the only spiritual guide to thousands who would never be reached by another?

" 'Here, if business continues to prosper, I can give liberally, and labor for the heathen by proxy; but money alone will not do the work, and laborers, especially physicians, are not to be found.

" Here, as an officer in an influential chureh, and various other benevolent societies, I may do much; and many think I ought not to change a certainty for an uncertainty. But do I not know that those churches that do most for the heathen and send forth the most laborers are most blessed of God? Can I not, then, do most for Christ at home by going in person to those who sit in darkness?

" But there are other ties, entwined with the tenderest feelings of nature; and how shall they be scvered? How shall I leave my parents, in their declining years? How say farewell 
to my sister and brothers? More than all, how ean I leave twc darling chitdren alone in this selfish world?

" "In these questions, so fall as mere feeling is concerned, though the heart thrill with agony, it should not turn the Christian from duty. My parents are not denendent on me. My going mat he the greatest hessing to my brothers and sister ; and what cain I do for my chiltren that would not be done for them il I am gone? The great thing to be done for at child is to fit him for usefulness here and the enjoyment of God in hearen. For this agencies can be provided, and superadded will be a parent's example, turning their attention to the great work he prays they may be qualified to pursue. If God calls me to leare them for his sake, he will take care of them. It may be the duty of others to go ; but would I let my neighbor die of hunger, because his rich brother ought to feed him rather than I? No more can I let millions perish forerer, because others do not give them the bread of life. I camnot, I dare not go up to judgment, till I have done the utmost God enables me to do to diffuse his glory through the earth." ",

This touching delineation of his inward struggles seems to include the whole up to his final determination to go, whith was not till after the meeting of the Board, in September, 1s:3t. No one can read it and not feel that he was an honest man; that, when he consecrated himself to God, he meant what he promised, and was resolved to fulfil it at whatever cost. With all his fearlessness and energy, he was naturally affectionate. Tis heart had a peculiar aptitude for the endearments of home, and nothing short of the voice of God could tear that yearning heart from the children it loval so well. But Providence had prepared the way for him to go. On the other side of the globe he had prepared a work for him to do, and the time drew near to bring them together.

On the 2Sth of October he offered himself to the Board, in the following letter to Dr. Anderson : 
"Dear Brotuen: Since our short interview I have been seriously cxamining whether duty to my Saviour calls me to labor in a foreign field. When $I$ think of the magnitude of the work and the importance of thorough preparation, and then of my own unfitness for a post of so great responsibility, my heart almost faints within me. But then, as I ponder the worth of the soul, and see millions going to the awful retributions of eternity, my heart grieves that so few heed their cries, and I am ready to exclaim, 'Here am $I$, - send ne!' At Jesus' call, and sustained by the blessed assurance, 'I am with you aluay,' I stand ready to go, in the face of dinger and leath, to any part of the world under the dominion of the prince of darkness. What though I tear away from chiltren and all the cndearments of home, wear out life amid toil and sufering, and find a grave among strangers? Only let me be the means of salvation to some lost sinner who shall meet me in heaven, and I shall bless God for it through eternity. Some of my friends doubt whether I ought to go from my children; but, though the question has perplexed me much, when I think with what confidence they would trust their dearest interests to my care while engaged in my service, shall I not confide them to my heavenly Father, while engaged in his? I often think with what sweet composure their dying mother said, while her countenance beamed with a heavenly smile, 'The Lord will take care of them.' And while I think of his faithfuncss as the hearer of prayer, $I$ fondly look forward to the day when they too shall preach Christ to the perishing.

" My only wish, in regard to a location, is to go where I am most needed. True, before conversing with you, my mind had turned towardis some extensive field. Since then, I have thought of the Nestorians; have read 'Smith and Dwight,' and, with a view to a better knowledge of the country, have reviewed Morier, Shoberl and Maltebrun, and so much of the Life of IIenry Martyn as relates to Persia. Should that sta- 
tion remain vacant, and the Board see fit to employ me, I trust their anxiety to send a laborer there will not induce them to send me to a post for which I am unqualified. But to their judgment I cheerfully submit the whole matter."

We have here a glimpse into the habits of reading begun in his school-boy days; and Dr. Auderson would seem to have suggesterl the Nestorians as the probable field of his future labor. Un the Sth of November - a little nore than a week afterwards - he discloses his feelings to his mother; for her training of the child had taught the man where to look for sympathy on such a subject. O that the church had more such mothers! Then would there be no lack of men to take up lis fallen mantle, and fill his vacant place. But to the letter :

"Mr Dear Mornen: $*_{*}^{*} * * *$ If to glorify the Redeemer in saving souls for whom he died be the all-important business of life, ought we not to make all else subservient to it, and, regardless of our own feelings, lay aside everything that would hinder its faithful prosecution? Is any saerifice too great to make for Him who sacrificed his life for us? I know too well that keen will be the trial of our separation; but how soon shall we meet again! and if then Christ approves, shall we regret the trial ?" He then presents the case somewhat as already given, and adds, "How shall I wish I had decided when I stand at the bar of God? Shall I not wish I had Jabored for the heathen who shall meet me there? What though here I might heap up riches, would they compare with the durable riches laid up for those who through much tribulation have washed their robes white in the blood of the Iamb? ******

"Dear mother, I would not act from a misguided zeal. I know that I need counsel from on high, and I hope you will ask it for me. God can give us wisdom, but let us see to it that we decide in view of eternity. I have solemnly consecrated myself and all I have to God; and I dare not go from his 
altar and stand convicted before the miverse of having loved the world more than God and the sonls of my dying fellownell."

Ne omit the remander, to make room for a few extracts fron a letter written on the anme day to his sister.

"Mr DeAr Sister Mary: ***** * Perhaps you say it is my duty to take care of the children God has commitied to my charge. It is clear that, unless they can have crery reasonable prospect of being trained up for usefulness. I ought not to leave them. But, should God cnable me to provide for them a home and a religious education, may he not have ofler work for me? Mistionaries send their children home, and in so doing camnot make provicion so well as I can in person. But, as this is an important question, let us look at it in its probible bearing on the Christian character of the child. As he thinks of his father, will he not think of God also? With his thoughts so often turned to the heathen, for whom his father libbors, will not their wants affect him? Will he not fecl the claims of God more; and, especially, will there not be nore fervent prayer offered for him, both by his friends and the church of Christ? Then, conscious too of going at his call, may I not leare them with entire confidence in my Sariou's care? * * * * *

"What though I nerer more shall meet the warm embrace of heloved friends on earth, - will our mecting be less happy where? Will we not hess God tor the privilege of suffering for his sake? Pray for me, that the Holy spirit may teach me what to do!"

On the 1 ith of Deremher he thus acknowledges the receit of his anointmot as mixionatry

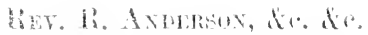

"Jnar Gire: Your letter was receired un Saturday, and bronght with it a sense of responsibility that, but for the throne 
of grace, hat been insupportable. I am more than ever sensible that my strength and wisdom must come from (iod. O, ior the guidance of his spirit! May itsholy, life-giving influence fit me for his service! It is my carnest prayer that the Jord would make me wholly his, that I may have no wish but to do his will. May that be my meat and drink, and I be enabled in all things to glorify his holy name!

I have much to do before I shall be ready to leare. Bust I have no doubt but the Lord will provide all that I want. Some pecuniary loss may attend so speedy a settlement of my affairs [he had been requested to he ready to sail at an carly date]; but I trust not so serious as to delay my departure, for which I shall prepare as soon as possible."

Not the least important part of his preparation was still to be made, in the selection of a comprnion to aid and eheer him in his missionary toil. If the experience of modem miscions has settled anything, it has settled the principle that a good wife is essential to the usefulness, and even the continued life, of the missionary. The heathen themselves have noticed that he who is alone is easily discouraged, and led to ahandon his post. It has been weil sitid, "No man ought to go as a missionary where woman eannot," - so necessary is her presence, not only to his checrful endurance, but aliso to his suceess. For, howerer a man may exhibit the fruits of piety in the individual, withont at companion he can never furnits the heathen with what they need more than all, - the right of a Christian fimily exemplifying the application of religion in all its relations. This $\mathrm{i}$ needed, both to conrince enemies of the excellence of (Hristianity, and to guide the yourg convert in the regalation of his own life at home. In many countries woman alone has alcess to her own sex, and without her they are not only unblest themselves, but active opponents to all efforts for the benefit of the men. Some missionarics have found, to their cost. that if the influence 
of woman in Christian lands is powerful for goor, that same influence l ses none of its power when it is employed in tho service of the prince of darkness. It is impossible to regenerate commmity while woman is left in the degradation of heathenism. Her influence at home is often more than a match for the missionary in his chapel. But, elevated by the efforts of her own sex, she becomes one of the most efficient co-laborers in the missionary work.

True, self-denial, and, in some eases, exposure to dinger, is required of the woman who would engage in the work. But is it not also required of the man; and has not the kingdom of Christ in every age been built up hy the sufferings of his followers of either sex? Are there no women among the noble army of martyrs? None anong those who toil and suffer at home, waiting for their recompense till the day of the Lord?

It deserves to be noticed, too, that the average length of the missionary life of woman, even in this incipient period of missions, when so much of the hardships of the pioneer have been encountered, has been longer than that of the stronger sex; and will not the comparison be much more favorable hereafter, in what some would call her more appropriate work of improving the little openings in the forest made by those who have gone before? Even in Mosul, where, as we shall see, so many died, the faets, instead of discouraging wonan from engaging in the work, encourage her to go lorward; for, while out of five men one only survires, only two women died out of three, and that third is still in the fich, while the survivor of the stronger sex is unable to resume his labors.

It is written, "Whoso findeth a wife findeth a good thing, and obtaineth firvor of the lord." Thi; was so eminently true in the case of Dr. Giant, as to justify a somewhat detailed aceount of the partner co his misionary life.

Miss Judith S. Camplell, the daughter of Erastus Iathrop and Judith Croftis, was born in Rutland, New York, on the 12th 
of Junury, 1s14, and was thus ahout seven years youmger than her future husband. When only three days old her mother died, and at the age of twelve months she was aldopted hy her mother's sister, Sabrina, wife of William ('ampliell, M.D., of Cherry Valley, in the same state. She was just the lady any one would have selected to train up a missionary. Jike the parents of Hr. Grant and his first wile, she too was from Connecticut. She was a woman of strong mind, well informed, and when converted entered with her whole heart into the work of doing good. The better to fit herself for this, she read medical hooks, and became such an adept in the arre of the sick that some of the most respectible physicians often consulted her when they found her at the bedside of their patients. Her scrvices to the poor in this way were mrenitting. "Perhaps no woman of the age," says one who kirew her, "visited the sick more than she did." She was also deeply interested in the missionary work, and prayed much that her daughter might have grace to engage in it. Nor did she pray only, but also educated her diligently for that end. Indefatigable herself in the pursuit of knowledge, and equally so in using it for the good of others, she infused her own spirit into her charge. She early trained her to habits of self-denial for the cause of Christ. When Judith was but seven years of age, a box was preparef by the ladies of Cherry Valley for Mr. and Mrs. Stewart, then leaving an adjoining town for the Sandwich Lkands. This was done mostly at the house of Mrs. Camplyell, and, to interest her daughter in the cause, she desired her to contribute a favorito pair of mittens. It cost a struggle, but she gave them, and from that hour felt a deep interest in the work. Thenceforth

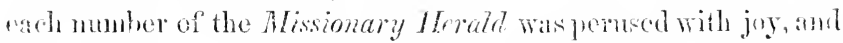
cron then she looked forwan with ereat dolight to the line when she might engage personally in the work. Long after, in l'ersia, she traced all her attachment to the cause batek to this litle incident, and the hallowed influence of her mother. Such 
things show how missionaries are made. They do not grow up by chance, - they are the result of the prayers and Christian training of pious parents, and especially spiritually-minded mothers. On her death-bed Mrs. Grant testified to this parental faithfulness, when she said, "What might I have been but for a pious mother! Under God, I owe ererything to my nother." 'That temple of the Holy Ghost which is buit of materials prepared heforchand by godly parents is the temile nost advantageously set over against the temple of idols.

The intellect of Miss Camplell, natuially strong, was well cultivated, and that with express reference to her future work. It was symmetrically developed, and very early showed a maturity that fitted her to adorn any sphere of woman's activity. Her father gave her the most thorough elucation our schools then afforded. She early applied herself to mathematies, and so well had she studied the Latin and Greek, that in Persia she was able to study the Syriac hy the aid of Latin lexicons and grammars, and turn to her Greek Testament for the elucidation of more difficult passages. In respect to disposition, she is commended, by all who knew her, as frank and artless, yet discreet, with a kindness that knew no limits; social, gentle, and lull of sympathy for others in affliction, while remarkably patient under her own. Nor need we be surprised by such a rare comhination of excellences, when we learn that each was heightened by, as well as rooted in, an affectionate devotion to Christ. She connected herself with the church April 5th, 1831, a day recorded in her journal as one of the most delightful she ever knew. Her piety was of that rare type at once deep and unostentations; miform, yet uniformly active and practical. She was already accepted by the Board when Dr. Grant became aequainted with her. He first makes mention of her in the following letter to Dr. Anderson, dated February 2.5, 1835:

“****** We are most anxious to pursue the course that will best subserr the cause so near our hearts. I say we, for you 
will rejoice to learn that a kind Providence has united with mine the heart of a young lady of most precions spirit, whose ardent piety, good health and highly cultivated intellect, fit her for extenkive usefulness. She reads Latin and Greek, and speaks French; and, though but trenty-one years of age, hats long been an alctive servant of her lierlecener. Her warm heart has for years yearned over the millions who hare none to tell them of his lore."

\section{She thus wites to her brother, March 10 :}

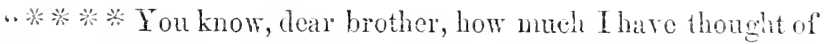
being a missionary, and how I have prayed to know my duty in the matier. Hitherto the way has seemed hedged up; but a door is now opened, and I am about to enter it. Ies, my dear, dear brother, I expect soon to leave these loved fumiliar scenes for I'ersia. The interesting ceremony that mites me with Dr. Grant takes place on Monday, April 6. * * * * $*$ Iapa feels very much about my going; still he does not oppose. When I look at tho inportance of the enterprise, and its bearing on the cause of Conist, I am dismayed at my own insufficiency. Bat I trust my hope is in God. In Jehorah alone is everlasting strength. In him all fulness dwells. I wish you could becone acruainted with 3)r. Grant, for I am sure you would like him. He has been an elder in Mr. Aikin's church three or four years, and bears the charaeter of an eminent and devoted Christian."

These letters show that love to Christ in each was the foundation of their attachment to one another, and we neel not wonder if such an affection was fruitful in happiness. The "interesting ceremony" took place on the appointed day, and they immediately set about preparations for departure.

This was attended with peculiar trials. Other missionaries leave home and friends, but they leave before they have formed attachments in an attractive sphere of usefulness. A large circle of friends did all in their power to induce Dr. Grant to 
remain. His own feelings were strongly attached to them. But the foreign field needs no man who will not be missed at home. And he who has not such ardent devotion to the work as will tear him away from everything else need not look for happiness in it, especially in such a field as laty before $D_{\mathrm{r}}$. Giant.

The leaving his two little sols was a far severer tial, as is evident from letters written both at this time and afterwards. But Providence hat provided for them an excellent home, with ML. Snith, of Utica, a kind friend and godly man, who promised to make up, so far as another can, for the absence of their own aflectionate parcut.

They left Utica on the 2 th of April, where $\mathrm{D}_{\mathrm{i}}$. Cirint had been staying for some time in the family of Rev. Mr. Crane. And now a son of Mr. Crane, who helped to pack their boxes and accompanied them to the packet-hoat, -- there was no rail. road then, - is gone, with his excellent companion, to labor in the very field opened by the toil and peril of Dr. Grant. Thus, as the Master calls one servant home, he sends forth others to carry on his work.

The feelings of Dr. Grant, at this time, may be gathered from a note written to his fither the next day at Albany.

“*垱淡 Trying as it has been to part from our dear, dear friends, we have been sustained, by the unfailing grace of Crod. I trust the trial will be sanctified to us all, and that we shall not be forgotten at the throne of grace. Our hope is in God. May we live near him, and be guided by his spirit!"

They sailed from Boston in the brig Angola, May 11th, with Miss Williams, from East Hartford, Connecticut, who was on her way to join the Syrian mission, at Beirut. 


\section{H A P T E R I I I.}

SMYRNA - CONSTANTINOPLE - VOYAGE TO TREBIZOND - JOURNEY TO PER SIA - MEETING WITIF MR. PERKINS- PASS OF DAHAR - FORTIFIED CAMP - TAERIZ.

Dr. Grant first set foot in Asia June 28,1885 , after a pleasant passage of forty-eight days. They landed at Smyma, and spent four or five days with the apostolic Mr. Temple, who, in the absence of numbers to share it with him, seemed to have inherited an unusual portion of the spirit of the beloved disciple who once labored there, - a better title to the epither "apostolie" than was ever conferred by mitred heads. He, too, has joined his guests in that blessed world, on whose borders he used to live while here. None was ever welcomed under his hospitable roof in whose memory precious thoughts of Christ and heaven are not realled by the very mention of his name. Dr. Grant's state of mind while here may be learned from a single paragraph of his first letter to Dr. Anderson from abroad, dated at Snyrna, July 1st:

"Since leaving Boston we have constantly experienced the rich mercies of our covenant God. For this we desire that gratitude which is evinced by a cheerful obedience to his whole will, and an unwavering trust in all his promises."

They left for Constantinople July 2, in the Maria Dorothea, one of the Austrian steamers, then just introduced into the Mediterranean. Her commander was Captain Ford, an intelligent Englishman, of whose kindness more than one missionary can speak with grateful recollection. They reached 
Constantinople on the morning of the 4 th, and were soon at home with the counterpart of their host at Smyrna, the Rev. Mr. Goodell. Their time passed pleasantly while waiting for a vessel to Trebizond; and, in their own words, they "became ardently attached to the beloved missionaries residing there." Here, too, they found the Rev. Mr. Merriek, who had spent some six months in the study of Turkish, preparatory to libor among the Mohammedans of P'ersia, and was now ready to accompany them to Tabriz. Besides the luxury of Christian fellowship, Dr. Grant here enjoyed what was to him a still greater luxury, - the privilege of doing good. He was called to prescribe for several of the Armenian bankers, - among others, Janik Agha, a leader among them, with whom the missionaries had in vain sought an acquaintance, till thus introduced by Dr. Grant. He was now in his element; and, as his eye took in the vastness and the destitution of the field, he writes: "If I ever had any misgivings for leaving a prosperous business, very" dear friends, and, more than all, for breaking away from two idolized sons, now that I see the work to be done, I can no longer doubt where duty calls." The unanimous testimony of both missionaries and native converts of the great good that might be done by a physician, in preparing the way for the preacher, was so corroborated by what he saw, that he adds, "I have not one regret for all I have left. To wear out life in this glorious work is far, far dearer than to enjoy the society of friends, however beloved; and it is only while obeying God that I can look up for his blessing on my children, and sweetly commend them to his care." This last utterance of his strong faith tells the secret of his "perfect peace" in subsequent affictions and distresses.

That he could take in at a glance the true relations of things, will appear from his description of the qualifications of a missionary-physician for such a place as Constantinople. "He must," says he, "be skilful; for his popularity will depend on 
his sureess in cases that have baftled those alrearly on the ground. Je must, have practical expericuec; for both disease and its treatment are so aflected by difference of climate that he cannot depend altogether upon books. Ile nust not only be able to rely on himself, bat to stand alone anid the opposition of other physicians jealous of his success; and last, not least, he must have tried piety, to stand firm anid the many temptations round about him."

He had many urgent invitations, from leading Armenians, to remain in Constantinople; and it was no narrow field of usefulness to which they called him. But his heart was alrealy too warmly attached to the Nestorians to let go its hold. In his first letter to Mr. Perkins, then in Tabriz, written July 22, he says: "I have thought of you with so much interest that I camnot refrain from introducing myself and Mrs. Giant by the Tatar (jost-rider) who leares to-morrow. I regret we cannot go with him in person; but hope, ere long, to exchange the cordial embrace. U, how anxiously have we looked to the hour when we may unite in your labor of love, and you not feel quite alone!" Even now, he cherished plans respecting the hitherto inaecessible mountaineers that thrilled his soul with manly enthusiasn; for thus Providence sows, long beforehand, the seed of a future harvest, and makes robust, by long and steady growth, the zeal that is to be called to perilous undertakings.

It would be pleasant to drell on the wouders of Constantinople, to go with IIss. Grant into Armenian houses, - the very elimax of neatness, - observe their strange customs, and partake of their oriental hospitality; or accompany them in a caique along the peerless Bosphorus, or up the Golden IIorn, by the Arsenal, the old palaee of Constantine, and the lovely groves and minarets of Eiyoob, to the Valley of Sweet Waters; or ramble with them over the hills of Beber, or among the dark cypresses of Scutari, that shade the dust of millions. It would be pleasant, too, to go with them to Agia Sophia, or the 



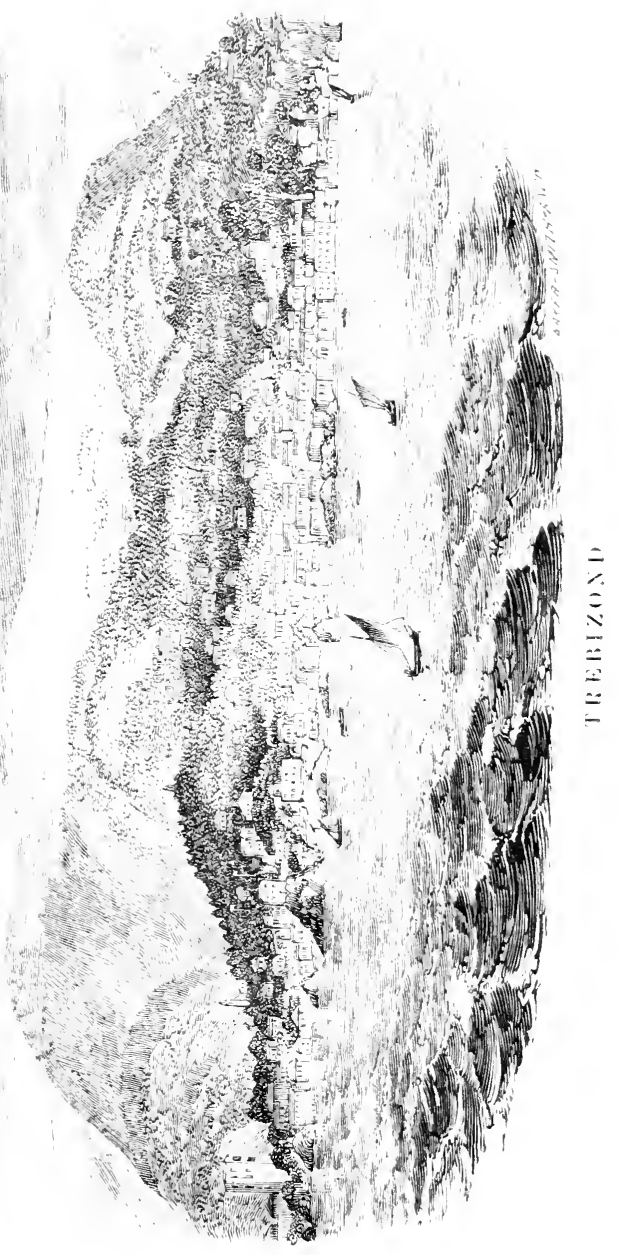


villa of our representative at St. Stefano. But, like them, we, too, must adrance still east from that oriental metropolis. The little schooner, that first left their own land on an unholy errand to Africa, and more recently carried Mr. and Mrs. Perkins to Trebizond, is now tugging at her anchors, as if impatient by another errand of mercy to atone for former crimes; and on the 19th of August they are on the way again to their still distant home. One of the passengers - Colonel Burgess, of Tabriz - came on board hardly able to walk; and thus Dr. Grant had an opportmity to do good to one who rendered them essential aid on their journey, and ever after showed no little kiudness to the mission. For eleren days they enjoyed the fine accommodations of the "Shah," and the attentions of an excellent captain, and landed at Trebizond on the 30 th. Here they formed an acpuaintance with the European consuls, of much service to them afterwards. They were also firored with an introduction to the Right Honorable Sir Henry Ellis, English ambassador to Persia, who also did all in his power to aid them. He eren requested them to apply to him for any assistance he might be able to render them, afterwards, at Oroomiah; so that the three pleasant weeks they were detained, for want of horses, in the family of the Rer. Mr. Johnson, then stationed there, may be classed among those things to observe which is to know the loving kindness of the Lord.

Trebizond, situated directly on the sea, its houses half hid den in fruit-trees, and the rugged mountains rising high in the background, was thought by Mrs. Cirant to he the most beautiful place she had seen in the East. The accompanying sketch of the town, as riewed from the sea may serve to justify her taste.

There was so much prejudice, at that time, against the missionaries resiling here, that they had scarcely any intercourse with the people. As he saw how easily a pious physician might remore it, Dr. Grant could hardly refrain from tears 
while he thought of the multitudes at home struggling for places, who might here aceomish so much for Christ.

On the 17th of September they commenced their journey, overlind, to Tabriz, - having, after so long delay, sueceded in securing a sufficient number of horses for the journey. Besides Mr. Merrick, they had with them an interpreter, aid lhree Nustorians, sent on to meet them by Mr. Perkins. The first night they pitched their tent in a retired valley, nine niles from the city, on the banks of the river of Trebizond. They had now left behind then the comforts of civilization, and vere just stepping into the privations and perils so longanticigated. Woman's timid apprehensions were soothed by man's more fearless selfreliance; yet, as neither know the things that shall befall then, together they cast their burdens on the Lord. Wre they retire to rest they commend themselres, dear friends at home, and the cause of one dearer than all, to his own grace and care. It was a place not soon to be forgotten; and wher, six years after, the bereared husband passed it alone, on a jet more perilous journey, is it any wonder that the strong heart bowed under the thronging memories of the past?

Next day their road, or, rather, path, - for it was barely wide enough for the passage of a single animal, - led along the edge of dizzy precipices on the steep sides of the mountains. Some of their horses fell in the narrowest places, and one was only saved by a tree from plunging headlong into the torrent lar below. Mrs. Grant rode safely in a sort of arm-chair, the Nestorians walking by her side, to steady it where there was any danger.

As the Sibbath was too cold and wet for them to pitch their tent, they spent the day in a khan, without floor or window. The top of the rough walls of stone and mud was level, on three sides, with the ground. They had neither chair nor table; but they spread their mattresses on two piles of leaves, in the corurs nearest the fire, and sat, surrounded by their baggage, 
piles of fire-wood, and smoking visitors. It was their first introduction to rural life in the List; and, rough ats it was, Dr. Grant writes, "Dear J_ not only bears her privations with fortitude, but seems really happier than ever before." And, further on, where they slept in the same room with the cows and horses, she writes herself" that she "never slept more comfortably in her life."

At Balahor, on the 22d, they were agrecably surprised by the arrival of Mr. Perkins, who had come from Tabriz in order to spare them, if possible, the repetition of some of the troubles that made his journey so distressing. Ile says of this meeting, in his sermon at the funeral of Mrs. Grant : "My first acquaintance with her was made in a stable, amid the snowy mountains of Asia Minor. The promptitude with which she came to our help, after hearing of the sufferings of Mrs. Perkins on the way, had already endeared her to our hearts. Her cheerful and intelligent countenance, her kind and artless manners, marle a very pleasing impression on my mind, - one which more than three years' acquaintance, in the same yard, and almost in the same dwelling, has only confirmed."

At Erzroom, where they arrived on the 26th, - four years before a missionary station was established there, - they were entertained by Mcssrs. Abbot and Kohrab, English merchants in that place, who showed them every attention in their power till they left again, on the 29th. They crossed the Aras next day, on a stone bridge of seven arches; and, on the 1st of October, started, at ten o'clock at night, and travellerl thirteen hours, so as to keep under the protection of the cara. van of Col. Burgess, in that dangerous part of the road. Dit. Grant was so exhautel hy romiting and pain, during the night, that he lay down to rest a few moments, about three o'clork, and was surprised, on waking, to find he had slept till laybreak, and was entirely alone. Providentially, he had retained hold of the bridle, and, by dint of hard riding, he 
overtook the cararan just as they were detaching a party to search for him. He then rode till one o'clock, and was soon quite restored by food and rest. This was on the mountainpass of Dahar, of which re shall hear again. They generally rose about two oclock; and at that early hour the cold, bracing air, and the soti beanty of an oriental sky, combined to render the ride delightful. On this part of the journey, the boxes and bites were regularly arranged, at night, in a hollow square, glade were stationed, and the tent: pitched in the middle of this extemporancous fort; and, in the lay-time, an armed train, with six hundred horses and some scores of donkeys, besides a mounted guard of soldiers, seemed sccure from the attacks of any ordinary banditti. Though the Kurds had, just before, been very troublesome, they passed hundreds of their black tents unmolested.

They had a fine view of Ararat and its perpetual snows as they passed it, some distance to the south; but were distresced to find New England rum well known where New England picty had not been heard of. Eighteen barrels preceded them into Persia, - no very fitting "avant-courier" for missionaries, howerer loully it called for their coming. Having travelled six humbed miles in twenty-eight days, - four of which they rested, - they arived at Tabriz on the morning of October 15th, - a much shorter time than the journey had ever been periormed by a lady before. At Constantinople and Trebizond they harl fount the plagie. Nere the cholera was now raging; but the same hand that preserved them from the one hat liept Mrs. Perkins from the othor, and soon all were quietly and pleasantly quartered in the city. They enjoyed delightfinl Christian intercomse with Dr. Riach, physician to the Guglish embassy, who was ever after a warm friend of Dr. Gant and the mission. Sir Henry Ellis, among other farors, 1" oposed that Mr. Perkins and Dr. Grant should apply for 
British protection; and, accondingly, furnished them with parsports, in both English and lerwian.

But they were not get at home, - Orooniah was still more than cne hudred miles distant. Mi. lerkins, as yet unacquainted with the language, had deened it in prudent to remove theie alone; and now, as it was thonght a physician would meet with a more favorable reception than a clergyman, and Dr. Giant, already called to prescribe for the Governor of Tabriz, harl received from him a letter of introduction to the Governor of Gronuiah, he was sent to seene a hone, and make arrangenients for the commencement of the mission.

He left, accordingly, on the $22 \mathrm{~d}$, just a week after his arrival. On the way he enjoyed the socicty of Mr. Hoernle and another German misionary, going to ascertain the feasibility of a mission anong the Kinds. They reached Gavalan, the residence of Mar Johama, on the 20 th, and next day he accompanied then to Oroomiah.

On their arrival, the governor provided them lodgings, and expresied a wish to sec them next morning. They alccordingly waited on him, and sat down on their heels, with the rest of the company, in tiue Perian style. The governor expressed great satisfaction at the arival of a physician, and some ten of the nobility present did the same. The doctor, willing to put this satisfaction to the test, requested his aid in finding a suitable resillence; and at once he sent his principal attendant to show him several, so that in less than a weck he had secured a very pleasant hou:e, on the borders of the Noslem and Nestorian quarters of the city. The location is high, and, for that city, healthy. It is near at gate, that opens into pleasant gardens; and firom Persim garmens we get om worl Paradise, as well as many of the leantie, that malse mp the idea. The house itedf had a garden attached, and a court, shaded with trees, where ladies could enjoy the air, without the amnoying publicity of walking through an oriental city. The whole is protected by a high mud wall; and, 
with such additions as the acconmodation of nore families required, continues to this day the mision premises, - thus evincing the wistom of the finst selection.

The governor sent carpets to furnish the temporary abode of the missionaries, and frequent supplies of fruit, and eren admitted them to the honor of a private interview. The Nestorians were not behindhand in their demonstrations of interest; and their numerous applications for medicine, while they gave our friend a foretaste of what was to come, greatly increased the interest he already felt in doing them good. When things seemed in a fair way to be ready for the arrival of the mission families, Dr. Grant returned to Tabriz, where he arrived again on Norember 6 .

But, before going back with them to their future home, let us take a brief view of the field before them. 


\section{CHA P T E I V.}

"IIS NESTORINS- ORIGIN OF THEIR CHURCI - EARLY IISTORY ANU MISSIONARY ENTERPRISE - LATER IUSTORY - DR. GRANT'S THEOKY OF THEIR JEWISII ORIGIN.

Comertaniry seems to have been introduced into Persia soon after the beginning of the Christian era. Whether the Magi were from thence ma be disputed (the Nestorian tablet of Singan Fu, in China, calls them Persians), but none can deny that Parthians, Modes and Elamites, witnessed the ronders of Pentecost; aind we can hardly suppose that on their return they would not speak of what they had seen and heard, or that none of those who heard them were converted to the faith. The Roman martyrology tells of Marius, a Persian noble, and his wife Martha, suffering martyrdom under Claudius, in 53 A. D. If, then, emigrants from thence were Christians, may not some who remained at home bave been the same? But scarce any record of Persian piety in those days has come down to us.

The churches in the East generally claim Thomas as their apostle; and might not the same facilities of communication that brought to Jerusalem proselytes from Parthia and Media carry back an apostle to those countries, or even beyond them? The actirity of apostles was not less than that of others. The love of Christ constrained them to go further and do more than other men. The fact, too, that we hear so little of Thomass in the region of the labors of Peter and Paul, seems to favor the tradition; for we camnot suppose that, while they were so abundant in laboris he was ille in the work assigued to him as 
well as to them. That devotion which was ready to go to Judea to die with Christ, that affectionate faith which cried "My Lord and my God," doubtless produced appropriate fruit. In the absence of proof to the contrary, may we not credit the universal testimony of the Lastern church? Thomas, then, and possibly Bartholomew, from among the apostles, and Adeus from among the seventy, were the earliest missionaries to the east of P'alestine. Those present at Pentecost must have wonderfully prepared the way, if they did not furnish active coadjutors. Thus often does the Lord of missions make all ready to the hand of his servants beforehand, as well as grant them his immediate presence.

Mares, a Jew and a disciple of Adeus, founded the bishoprie of Selencia. He died in 82 A. D., and Abres, said to belong to the family of Joseph, the reputed father of our Saviour, succeeded to the office. The eighth in succession, Achadabues, son of the seventh, according to Mares, and also said to be of the family of Joseph, shows that in those days, at least, marriage was still "honorable in all." The next in order, Schiachlupha, instead of being ordained at Jerusalem or Antioch, and sent thence to Selencia, was ordained on the spot, about $160 \mathrm{~A}$. D. Several of his successors suffered martyrdom under Sapor, King of Persia, with multitudes of other ecclesiastics and private Christians. Assemani quotes Mares as saying that more thạn one hundred and sixty thousand suffered martyrdom in Beth Garmæ alone, soon after the year 300. But those times of martyrdom were also times of fearless missionary enterprise. In 256 a bishop was sent to Busra. The first incumbent of Susa was slain where Nehemiah basked in royal fivor; yet, undeterred by his fite, the line of succession continued unbroken till 1281. Eren so far off as Toos, in Khorassan, where no missionary now is heard of, a bishop was settled in 334; and in the neighboring city of Merw a metropolitan existed as early as 420. 'There must have been a large Christian pop- 
ulation and many bishops round about, to have justified the erection of a metropolitan see in that remote region. Nine years before that a similar see was established at Herat, in Affghanistan though some date it in 503, and others as late as 714 .

"The incumbents of Seleucil, at first called bishops, were afterwards called archbishops. Simeon, the eleventh of the series who suffered martyrdom in 330, Sozomen says, was the first known by that title, though the old Syrian and Greek writers speak of bishops only till after the thirteenth, who was slain by Sapor, 356. The catalogine of the Chaldean patriarchs calls the twenty-third, who died 496, Catholicos; and a Syriac writer gives the same title to his successor, Babaus, elected by the followers of Nestorius, now for the first time the majority in the Lastern church. Owing to this difference, the see now renounced all dependence on Antioch, and set up for itself, claiming for its incumbent the title of Patriarch of the East, the present title of Mar Shimon; so that the Nestorian church is really the ancient church of Seleucia, an original branch of the church of Antioch.

Just before this, Barsumas, the famous bishop and teacher of Nisibis, had diligently disseminated the tenets of Nestorius. The personil character of both him and Babæus it is difficult to make out from the opposing testimony of different writers. All agree that he abolished the celibacy of the clergy, that with other corruptions had already been engrafted on Christianity. Like a later reformer, himself set the example of marrying a num. Babæus extended this reformation to the office of patriarch, much to the grief of the papal historian, who records this return to apostolic practice with the lamentation that no less than five patriarchs confirmed "this impure law" by word and deed, and notes the fact that Silas, the successor of Babreus, gave his daughter in marriage to Elisha, the next incumk ent of the patriarchal throne. It needs a more 
thorongh and impartial reeension of the original docunents than has yet been made to determine the nawure and extent of the change at this period, and whether or no it were really a reformation. Perhaps some graduate of the seminary at Iit. Seir will do this service to the church, and forever put to rest the foul aspersions of the papists, whose interest it is to misrepresent and traduce any deviation from their own corruptions. If, as we would fitin hope, that was an honest effort at reformation, doubtless the patriarchal mansion was a purer and happier home than it has been since its oceupants again sought to improve the arrangements of God, and learned by sad experience whose was the better plan. Had that reformation been carried out in other matters, the great Reformation had had an earlier date, and, instead of Germany, had occupied a centre not far from the original paradise of the race.

The change of name and external relations, howerer, brought no change to the missionary activity of the church. Cosmos Indicopleustes, who travelled about 535 A. D., says that then there were many Nestorian bishops around Aden, in Arabia, and on the island of Socotra, in the Indian Sea. Gibbon says, Irr. 272, according to this traveller, in the sisth eentury, Christianity had been successively preached to the Bactrians, Huns, Persians, Indians, Persarmenians, Medes and Elamites. The barbaric churches, from the Gulf of Persia to the Caspian Sea, were almost infinite; and their recent faith was conspicuous in the number and sanctity of their monks and martyrs. The pepper coast of Malabar, Socotra and Ceylon, were peopled with an increasing number of Christians. Abulfida, who wrote about 1300 , tells us that Socotra was then inhabited by Nestorians, and we know that one of its bishops was present at the ordination of the I'atriarch Jeballaha, in 1281.

Damascus had a Nestorian bishop in 628, and a metropolitan in 800 , with subordinate bishops at Aleppo, Jerusalem, Membij (Hierapolis of the Greeks, and Bambyce of the ancient Syrians, 
not far west from the Euphrates), Mopsuestia, Tarsus and Malatia. He bore rule over the Nestorians in Egypt, Palestine, Syria and Cilicia.

John was present at the council of Nice, in 325 , as Bishop of Persia and India; and the latter country had a metropolitan from 852 to 1720 . In 1504 the Nestorians had fifty cities in Malabar, besides the city of Meliapore. Gibbon says the Nestorians in India had one thousand four hundred churches, containing two hundred and eighty thousand souls.

In China a recent writer (S. W. Williams, of Canton) thinks the Nestorians were found as early as 505 A. D. Olopun was Bishop of Nankin in 636, and there was a metropolitan in Pekin in 714. In earlier times there were two metropolitan sees in China; one called Chambaluch, or Chanbalek (Pekin), and the other Tanchet, or Tanghut. But these were united in 1268. In 1625 a Chinese inscription was discovered at Singan Fu, in one of the western provinces, which had been erected by Nestorians in 781 (some say 782), giving an account of the Christian religion, and a list of ecelesiastics who had labored in China. The missionary efforts of the Nestorians in China seem to have ceased about the time of the expulsion of the Moguls, in 1369; and after that time they gradually declined. It has generally been supposed that all traces of their labors have been obliterated in China; but a missionary in Ningpo, which is on the coast, a little south of east from Singan $\mathrm{Fu}$, writes that "a respectable stranger from one of the western provinces came to our chapel, and listened with much attention, After service, he said that he and his ancestors worshipped only one God, the Creator. He knew of Moses and Jesus and Mary; said he was not a Romanist nor a Mohammedan, neither had he seen our books, but that the doctrine was handed down from his ancestors for many generations. He said that in his native place thirty families are of the same religion. who had books, but did not circulate them." Is not this one of the descendants 
of the Nestorians? - a living witness to their missionary labors? Who knows but some evangelist from a regenerated church in Persia and Kûrdistan shall, in the province of that stranger, revisit and build up on a still more permanent foundation the waste places of many generations?

Timotheus, patriarch from 778 to 820 , sent Subchaljesus, a monk of Beth Abe, who knew Turkish, Arabic and Persian, to the countries beyond the Caspian. He baptized, built churches and ordained priests; then leaving them to instruct the new converts in psalmody, he penetrated Eastern Tartary, and on his return to the patriarch was slain by the barbarians. Nothing daunted, Timotheus at once ordained two others from the same convent, and sent them to fill the racant post. They took fifteen of their companions with them, and it may illustrate the Christianity of the time to relate that, when some of these fifteen were needed as bishops, the patriarch directed that, as three bishops were needed to ordain one to the same office, and they were only.two, they should place a copy of the gospels on a chair at their right hand for the third, and thus, having ordained the first of their companions, by his aid they might ordain the others as usual.

It may seem strange that, while even a scoffer admits that "their zeal overleaped the limits which had confined the ambition and curiosity of the Greeks and Romans, pursued without fear the footsteps of the roving Tartar, and insinuated themselves into the camps of the ralleys of Imaus and the banks of the Selinga," there should be so few permanent results of their zeal. But our wonder will cease when we read of another missionary asking the patriarch how to observe the forty days' fast from animal food, since the Tartars subsisted entirely on flesh and the products of the dairy, and had neither bread nor regetables; and the grave reply that they need abstain only from meat, and that, whereas they had heretofore used their milk sour, they should now drink it sweet, as a token of their 
conversion. Khorassan, too, is said to have become Christian, because the idolaters, finding they could neither break nor burn the shrine (arcam) of Mar Elias, concluded to worship before it. Abulfaraj tells of a king of the Tartars about 1000 A. D. (Unkhkhan, or the celebrated Prester Johu), who became a Christian because, when lost in a snow-storm, a saint appeared to him in a vision and led him safely home, on his promise to do so. The same author gives a curious description of the converts, when he says that in 1046 they broke through Mount Imans, between Thibet and Khotan, under seven leaders, each with seventy thousand horsemen, most excellent arehers, simple and abstemious in diet, but swarthy ais Indians, unwashed, their hair uncut and stiffened with grease till it served them for a helmet, and their horses feeding on flesh; a very different pieture from either converted Hottentots in Caffraria, or Christianized cannibals in New '/ealand.

Whether the evanescent nature of such conversions argues that the work which our missionaries build upon Jesus Christ, the true foundation, will not abide, the reader may decide for himself. Neander does not speak very highly of these converts. He thinks the missionaries were as easily contented with an external performance of certain ceremonies as the Tartars were ready to perform them; and speaks of a Khan Mangu, who, on festivals, used to have Nestorian priests in their robes offer up prayers for him, and pronounce a blessing over his cups; then had Mohammedan priests, and, last of all, Pagans, do the same. But his authorities are papal missionaries, and their testimony must be receiver as that of rivals. May we not hope for some testimony yet to be adranced from Nestorian records?

While this activity, whatever it was, prevailed abroad, the church experienced many ricissitudes at home. At Seleucia, it was sometimes in favor, but as often persecuted by the Persian emperors; and when they were overthrown in 762, the patriarch removed to Bagdad, the new capital of their Arab conquerors. 
There they enjoyed unusual prosperity ; they were much in favor at the court of the Caliphs, and employed by some of them to make translations of Aristotle, and other celebrated Greek writers, into the Arabic. This favorable state of things lasted till 1258, when the city was sacked by the Tartars; and it is worthy of notice that this period - that is, from 762 to 1258 - was that of the greatest missionary activity of the Nestorian church. The Tartars at first favored them, but when they embraced Mohammedanism became their bitter persecutors, and, towards the close of the fourteenth century, the Nestorians were almost exterminated, in many regions, by the merciless Tamerlane (Timûr). It will give some idea of his ferocity to state that in 1380 he built up two thousand men alive with mortar, in the form of a tower, who thus miserably perished. Seven years later, he piled up seventy thousand human heads in the public squares of Ispahan, and in 1401 ninety thousand in the city of Bagdad. Three years previous, he massacred one hundred thousand prisoners in his invasion of India ; and in $\mathbf{1 4 0 0}$ he buried alive four thousand Armenian horsemen, whom he had taken prisoners at Sivas. Such was the man whose fury seems to have put an end to the missionary activity of the Nestorians, while from many countries it blotted out their very name.

After 1258 , the patriarchate was removed hither and thither, till in 1560 it became fixed again in Mosul, and was at the celebrated convent of Rabban Hormuz when Assemani wrote, in 1725 .

In 1551, at the death of the patriarch, as only one metropolitan remained out of the twenty-five who had ruled from China to Egypt, and from Northern Tartary to the island of Socotra, and three at least were needed to perform the ceremony of consecration, the new patriarch was sent to be ordained at Rome. That the relations this involved were not very intimate, is evident from his successor, Elias, being refused communion with Rome in 1586 , and the Elias who filled the patriarchal chair 
$1629-59$, in turn, refusing communion with her. Shimon, Arehbishop of Jelu, Sert, and Salmas, refused obedience to Elias in 1575 , and was elected patriarch of the Nestorians of Kûrdistan; and his successors ever since have borne the same name, while those who inherited the name of Elias with his office retained authority over Mesopotamia. Thus there were two branches of the Nestorian church, - one in faith, though under distinct patriarchs, and still another was consecrated patriarch of the Chaldeans (Nestorians who have seceded to Rome) by the Pope in 1681, under the title of Mar Yoosuf, who resided at Diarbekir till about 1780, when the submission of Mar Elias to Rome obviated the necessity of this soparate organization. This secession was secured partly by bribes and partly by violence, and was followed by still severcr oppression of the proselyted patriarch. At his death, in 1841, his office, instead of descending to his nephew, according to previous custom, was conferred on a Chaldean from Salmas, and the very name of Mar Elias exchanged for that of Mar Nicolas, by a decree from the Pope. Nor is this interference with the patriarchate the only wrong Rome has inflicted on a sister church. She has altered her ancient liturgy, introduced her own idolatrous worship of images, suppressed the second commandment, and, as a matter of course, forbids the circulation of the Scriptures, that would expose the mutilation. The people are restive undor her yoke, and the day of retribution may be near at hand. The nephew of the patriarch thus superseded has changed from the Chaldeans to the Nestorians, and vice versa, hoping to recover the patriarchate; but, instead of that, he now lives in obscure porerty in the very village where the intrigues and violence of Rome have placed another in his rightful inheritance.

It is diflicult to give an accurate statement of the doctrines of the Nestorians. For, as a church, they have no regular confession of faith, and their treatises on Christian doctrine express the views of individuals, rather than the belief of the 
whole body. Nor is a missionary biography the place for such a dissertation The subject is discussed at length by Dr. Perkins, in the Ancient Christianity Exemplified of Rov. L. Coleman, pp. 564-580; and still more extensively in the second volume of The Nestorians and their Rituals, by Rev. G. P. Badger, where the original authorities are translated and arranged according to the thirty-nine articles of the Church of England. That "exposé" shows much chaff as well as wheat, and exhibits a strong tendency in the Nestorian fathers to the exaltation of the priesthood and external forms, at the expense of spiritual truth.

But the "mystery of iniquity" was at work even while the apostles lived, and the gospel had lost much of its purity beforc the Nestorian church came into existence. Yet she was an early and efficient patron of education. The school at Edessa was founded by Mar Ephraim, about the middle of the fourth century. That at Dorkena, in 385. The school at Nisibis, founded 490 , had a three years' course of biblical and theological studies, besides mathematics, medicine, grammar, belles-lettres, music, astronomy, \&c. \&c.

Neander says, "The Nestorian seminaries for the clergy, at the beginning, were particularly distinguished." So much so, that even in Northern Africa, Bishop Junilius, about the middle of the sixth century, describes the school at Nisibis as one "where the Scriptures were expounded by teachers publicly appointed, in the same manner as grammar and rhetoric among the Romans." Afterwards schools were established at Bagdad, Mahuza, Beth Abe, Tirhana, Maragha, and other places, besides one as fur off as Khorassan.

Such a course of education was fitted to give great prominence to Scripture doctrines; and Mosheim tells us that the Nestorian commentators of the sixth century were the best of the age, as they alone sought for the true meaning of the inspired words. Compared with the other churches of the East, 
she is well worthy of having her sons called "the l'rotestants of the East;" but truth compels us to admit that it is only comparatively. Their prompt reference of all points in rebate to the Scriptures, and readiness to abide by their decision, renders the Nestorian church an exceedingly interesting field of missionary labor.

It has been well said by another that "her missionary activity is both the cause and effect of her comparative purity." The peeuliar doctrines of Nestorius himself have been so often stated in works on the Nestorians, that we will here omit the repetition, especially as there will be no occasion to refer to them, in the course of the narrative.*

Dr. Grant pored with eager interest over the history of this aneient ehurch. The story of her martyrs under Sapor, and the more ferocious Tamerline, drew his heart cleser to the remnant that remained. The memory of her schools led him to form bright hopes of the future of a church so distinguished in the past. But, most of all, the missionary heroism of those who went out from these schools through the length and breadth of Asia thrilled a heart so sympathetic with their own. He loved the Nestorians. He toiled for the revival of apostolic piety in that primitive church; not merely for its own salvation, but as the regenerator of the millions round about it. He gave himself to his work, with his eye ever fixed on the time when those for whom he labored would go forth in the footsteps of their fathers, to rekindle the fire on the ancicnt altars, and restore the former desolations on a more permanent foundation. It was pressing toward this goal that he endured hardness like a good soldier, and boldly advanced, even in the face of death itself.

* For a detailed account of the controversy between him and Cyril, see Neander's Church History, II. 446--495, which gives a very favorable view of the piety and orthodoxy of Nestorius, and a picture of his opponent by no means to his credit. 
In a memoir of J)r. Grant, it will be expected that some notice be taken of his belicf that in the Nestorians he had found the lost tribes of Israel. This to him was a settled truth. His confidenee in it never wavered till the last. He had collecter what he deemed strong confirmations of the positions taken in his work on "The Lost Tribes," and, had he liverl, would have one day given them to the world. Part of these consisted in written documents from the Jews in Kûrdistan, showing that their language was identical in origin with that of the Nestorians. He had also collected historical evidence to show that Assyria and Babylon were not only distinct, but so at enmity with each other, till after the return of the two tribes from the latter kingdom, that that event could not influence the ten tribes, so much longer settled in the other.

Though others may not share his zeal in this matter, none can deny that it imparted a tone of uncommon energy to his missionary life. He felt that his labors were connected with the fulfilment of some of the most precious promises of God to his church. That glorious future was to him a present reality; so that, where others saw only discouragement, his eye glaneed forward to the brightness beyond. It seemed a special provision of Providence to sustain him in his many trials, leading him to look less to man and more to God. It made eren heary afflictions to work out a far more exceeding and eternal weight of glory, while he looked not at the things that are seen, but on the unseen and eternal. His exposition of the two witnesse:, p. 322-4 of "Lost Tribes," was often referred to, both in letter's and conversation, as affording him strong support under the distressing calamities of the Mountain Nestorians. 


\section{CHAPTER V.}

ARAIVAL IN OROOMIAH - MISSIONARY PHYSICIANS - CHOLERA - LABORS AND LETTERS OF DR. GRANT - LOOTEE - LABORS OF MRS. GRANT.

TuE province of Oroomiah lies in the north-western part of Persia. The lofty mountains of Kurdistan look down on it from the west. On the east the beantiful lake of the same name extends, about eighty miles in length and thirty in width. It is four thousand one hundred feet above the level of the sea, and so salt that fish cannot live in its waters, though numerous water-fowl - among which the beautiful flamingo is most conspicuous - enliven its shores. A highly fertile plain gently slopes from the mountains to the lake, comprising an area of about five hundred square miles, and dotted with not less than three hundred villages. These vary in population from one hundred to one thousand inhabitants. The whole region, from Khoy on the north as far south as Suldtuz, is a perfect garden. Several rivers from the momntains are almost drained to irrigate the fields on either side. The roads in every dircetion are shaded by trees, often cxtending the most delicious fruit within reach of the traveller. The landscape is one of the loveliest in the east, - willow, poplar and sycamore trees line the water-courses. Peach, apricot, pear, plum, cherry, quince and apple trees, impart to some portions the appearance of a forest, while the vineyards, and luxuriant fields and gardens of the plain, form a striking contrast to the naked aspect of the mountains. On these not a solitary tree is to be seen. Among them, however, are two hundred villages belonging to the prov- 
ince, half hidden in lovely valleys, or perched high on steep hillsides. One of these last is now the summer residence of the mission, at an elevation of fourteen hundred feet above the lake, while the mountains of Kurdistan rise behind to the height of twelve thousand feet, some of them crowned with snow throughout the year.

Near the centre of the plain, and about four hundred feet above the lake, stands the city of Oroomiah. It dates from a distant antiquity, and claims to be the birth-place of Zoroaster. Not far to the east of the eity, an artificial mound, about seventy feet high, marks the site of the temple where he fed the sacred fires. It is a walled city, of nearly four miles in circumference, and contains about twenty thousand inhabitants. Of these, six hundred are Nestorians, two thousand Jews, and the rest Mohammedans. The flat-roofed houses are mostly built of mud or sun-burnt bricks, and are enclosed with high walls of the same material. Often the house itself forms one side of the enclosure. The more wealthy have beautiful gardens attached to their dwellings, where the family can enjoy themselves, secure from all intrusion.

Here, and in the villages of the plain, twenty thousand Nestorians furnish a most inviting field of missionary labor. The same causes that led their ancestors to faror Persia, rather than Rome, now render them peculiarly jealous of the Pope. Just as the tragic story of Hassan and Hossein feeds the hatred of the Persian Shiite against the Soonees of Turkey, so have the wrongs of the banished patriareh of Constantinople, and his death among the sands of Libya, fed the hatred of the Nestorians against both the eastern and western chureh. This has tended to keep them comparatively uncontaminated by the corruptions of Rome. While that church forbids the circulation of the Scriptures among the people, they appeal to them as the standard of faith, and desire their diffusion among all classes in a language they can understand. Their forms are simple, and 
more seriptural than those of other Eastern churches. They abhor image-worship, auricular confession, and the doctrine of Purgatory. And yet, as a church, they had sunk into the grossest ignoranee. None but their elergy could read or write. Female education was unknown, and the observance of fasts and feasts usurped the place of holiness in heart and life. Still, some, conseious of their degradation, seemed to seck for better things; and all hailed the arrival of men who brought with them the Bible, and promised to revive the glory of their ancient schools.

With such encouragements in the people themselves, their location was no less promising. Out of the usual rontes of commerce, it was also out of the way of those European vices that contaminate even the heathen. For the wickedness of some, away from the restraints of Christian linds, as fatr excels the wickedness around them, as their intelligence and energy exceeds that of the degraded people anong whom they dwell. Where such men occupy positions of influence, they overshadow the missionary, and counteract his labors. His piety does not relieve Christianity of a tithe of the reproach east upon it by their vices.

But in Oroomiah, as the missionary was first on the ground, men got their idea of Christianity from his character; and this influence for good was as unchecked as it was extensive, for neither vicious example nor direct opposition was there to interfere. The whole weight of European superiority in art and science was thrown into the scale of morality and religion, and made subservient to the glory of Christ.

Such was the field Dr. Grant now entered, and his esteemed predecessor still lives to reap the harvest they sowed together. That they were happy in each other may be inferred from a letter of the latter to Dr Anderson, November 4, 1835, in which he says, "Permit me to say that, from my short acquaintance with Dr. Grant, I have great confidence that your choice has been remarkably successful." And again, October 27,1836 , he silys to 
a missionary friend, "Having lived in the same yard with Dr. and Mrs. Grant now for nearly a year, I venture to affirm that four hearts were never more happily united in missionary plans, eares and labors, than ours." While Dr. Grant writes to Dr. Anderson, November 10, 1835, "Permit me to express my gratitude to God and to the Board, for placing me with such an invaluable associate as I trust I have found in Mr. Perkins."

Dr. Grant left Tabriz again on the very date of this letter, to get the houses in readiness for the mission fanilies. But so very slow were the movements of the carpenters, that Mr. Perkins and the ladies, who left six days later, found things quite unprepared for their reception. The date of their arrival in their new home was one long to be remembered. After riding all day in a driving storm of rain, they were introduced into an open room, and sat down with the carpenters among the shavings. It was late in November, and very cold. Then, as Dr. Grant had not expected them in the storm, and their loads were left behind, they had neither bedding, provisions, nor a change of clothing. A large fire, however, was soon blazing; bread and kebabs (small morsels of meat roasted on skewers) were procured from the market. A long ride had sharpened their appetite, and after a vigorous attack on the huge loaves, or rather

- leaves ( they were more than two and a half feet long, by one in breadth), with their savory contents, they slept sweetly on the piles of shavings, covered with the cloaks they had dried by the fire. Still, even thus, there was no place like home; and, with grateful hearts, they loug observed the 20th of November as their Pilgrim's day. They were obliged to occupy their houses at once, just as they found them; and while the grains of barley sprouted in the mud-plaster of Mr. Perkins' chamber, partially heated by a store in an adjoining room, the frost stiffened the bed-clothes of Dr. Grant, whose room was not thus warmed. Such exposure doubtless prepared the way for the sickness that followed. But, as the rainy season had set in, to 
have delayed longer linght have been to fare worse; and to have spent the winter at Tabriz might have hazarded the prosperity, if not the rery existence, of the mission.

Mrs. Grant thus describes her arrival, in a letter to Mr. Merrick, dated December 3 :

“* * * * * I am now quite well, and very, very happy. I feel that I have at length reached my home, and that my wanderings, for a time at least, are over. $O$, ' $t$ is so sweet to sit by one's own fireside, with those we love about us ; but sweeter: still to surround our oun domestic altar, and unite in prayer and praise to our heavenly Benefactor!

"I have wished a hundred times, dear brother, that you were a sharer in our joys. I cannot describe my emotions when first saluted by our Nestorian friends. The bishop eame galloping out to meet us, his whole countenance glowing with delight. 'How do you do? - I 'm very glad to see you,' were his first words. To be addressed, on my entrance to my missionary field, in my own language, was indeed affecting. We were met by many of the villagers, with the father of the bishop at their head, and received from them a most cordial welcome. His mother and family also greeted us very affectionately, so that we felt as if we were among near friends, if not relations.

"I was much affected to hear the brother of the bishop, a boy of fourteen, read in the English Testament as well as most boys of his own age at home. I covild only sit and weep, inwardly thanking God for all that mine eyes saw and ears heard." *** *

They were hardly settled before the governor sent to welcome them, and as soon as possible came in person. The Nestorians sent in many presents, and in every way testified delight at their coming. Mar Yohanna gave his younger brother to Dr. Grant, to study English and medicine, even before he reached the city; and himself was an inmate of his family, till the pressure of 1837 compelled the mission to dis- 
miss him from their service. Dr. (irant was at once so thronged with patients that he could scareely find time to attend to anything else. As soon as possible, he opened a regular dispensary. The nobility and clergy, as well as those too sick to come, were visited at their houses. The rest thronged the dispensary in erowls at the stated hours. It was interesting to see Moslems and Nestorians eoming together to receive kindness from the stranger, who ministered to all for Jesus' sake. The aged were helped forwarl by their children. Little ones were brought by their anxious mothers. Some, hardly able to wakk, were supported by their friends; and others, led by the hand, utterly blind, from ophthahnia. The languid face of the sick turned sadly on the physician, while each word and look was marle a basis for hope, or a confirmation of their anxious fears.

Says Dr. Grant, in a letter to Dr. Anderson: "As I have witnessed the relief of hitherto hopeless suffering, and seen their grateful attempts to kiss my feet, and my very shoes at the door, both of which they would literally bathe with tears, - especially as the haughty Moollah has stooped to kiss the border of the garment of the despised Christian, some thanking God that I would not refuse melicine to a Moslem, and others saying that in every prayer they thanked God for my coming, I have hoped that, even before I could teach our religion, I was doing something to recommend it, and wished that more of my professional brethren might share this luxury of doing good."

But, with all this, there was much to try the patience. Children, with ferers, or summer-complaints, eame eating unipe fruit, and their parents would often go away without medicine, rather than take it from them. Others, after listening to the most specific directions, still asked a thousand questions. Must the milk allowed for diet be that of a goat, sheep, buffalo, ass or cow ; and, if the latter, what must be her color? - for, according to them, that of a white cow is cold, 
and of a red one hot. For a similar reason, they inquire what rnust be the sex of the chicken used to make the broth prescribed; - one article is dry, and another moist; this makes blood, and that bile; one vein in the arm takes blood from the head, another from the liver, and so on. And, if too ignorant to ask all these learned questions, the patient not unfrequently asks whether he is to swallow paper and medicine too, - if this is not done at once, without inquiry. Then the directions must be repeated orer and over, the sick man must know the name of his disease; men of rank must have the pulse felt in both wrists, and then be told every ache and pain they have, without further questioning. Or, if free from both, they must be told what medieine to take to remain so. These are a few of the annoyances, occurring perhaps fifty times a day. And, after all his labor, the efforts of the physician are often rendered vain, by the patient's going exactly contrary to a plain direction as to medicine or food. Wren in the most alarning diseases, the physician eannot prevail on them to touch a spoonful of chicken-broth during a fist. If he remonstrates, they reply that they will sooner die than yield. Dr. Grant's practice among the Irish of Utica must have been a good introduction to what lay before him in Peria and Kirdistan.

But sometimes he got more eredit than he deserved. He once applied a blister behind the ear of a Persian noble, for a local pain, caused by exposure in coming ont of a bath in winter. It drew finely and cured the patient, and the doctor had the credit of perceiving that all that water had run into his ear in the bath and fiozen there, and then such a wonderfully hot medicine as he had to thaw it out! While such incidents procured him a gieat name among the people, the real bencfits he conferred procured more of real reputation. Fispecially did the sight restored to many by the removal of cataract give him an immense influence to employ for Christ. Patients eame as 
many as five days' journey; Nestorians from the mountains, Kûrdish chiefs even from Amadia beyond, and some from the distant borders of Georgia. Among the thousands who thronged him were nuny of the highest rank and influence,the governor of the province, two princes of the royal family, and many of the P'ersian nobility.

And yet all was done so prudently that, though his services were entirely gratuitous, he gave no offence to the native physicians. There was no show to attract customers, and he was ready to aid the native practitioners with both medicine and instruction.

He felt that a missionary-physician should seek to win their friendship, and prepare them for usefulness. It is vain to hope to supply the heathen with enlightened physicians. But he thought that, in a spirit of love, much might be done towards relieving the great mass of suffering he could not possibly attend to in person, by elevating those they had; and on this principle he always acted. A petty professional jealousy formed no part of the character of Dr. Grant.

He declined attendance on their wealthy patients, unless for some special reason; and in Mosul, at least, if there was no Epecial intimacy, he consented to visit them only as a consulting physician. There, too, he required all who came to bring a teskereh (certificate) from the Priest, Moollah, or Rabbi, as their sect might be, testifying that they were proper objects of charity, before he would prescribe. This relieved him from the annoyance of many trivial ailments, and at the same time enabled the clergy to show kindness to the poor at little cost. While he thus shared with them the credit of the cure, he also effectually prevented their persecuting such of their people as were inquiring for the truth.

A Jacobite bishop once anathematized all who came to the Americans for medical aid; but he soon found he was reckoning without his host. The people would not be kept away, and the 
clergy who came themelves could not refuse teskerchs to those who really needed them.

These things show the importance of a pious physician in the earlier stages of a mission. Our Saviour knew what would give his ministers access to men; and while he himself went abont healing all manner of disease, he gave power to his disciples to do the same, and sent them to heal the sick as well as preach the gospel. We know how Paul employed this gift of healing to open a way for the truth; and the cure of a lame man in the temple, by Peter and John, laid the foundation for a sermon second in its results only to that delivered on Pentecost. Those miraculous gilts have passed away, but the human heart will never cease to be susceptible to snch kindness. A heathen may be deal to the most moving discourses of Christ and heaven; but, let the missionary relieve his bodily suffering, and then tell him he does it for Jesus' sake, and speak of what led him to love that Saviour, and what Christ is able to do for all, and he secures a hearing few others could obtain. It is difficult for a missionary, as such, to gain access to a people. The Moslem still hates Christianity. Heathen are suspicious of a stranger. The nominal Christians of the East are full of prejudice, and emissaries are not wanting to exeite that prejudice, or even ercate it where it is wanting. From such causes the mere missionary may remain for years icolated and shmned, if not despised, and all opportunity of doing the good he yearns to do be utterly denied him. But the missionary physician is sought hy all. The horel and the palace open alike at his aproach. Eren the harem, where a brother may not intrude, is not too sucred for "the infidel," when he enters as an angel of mercy to the sick and rying. Thus he renches the heart when most suseeptible to the truth, and, introrlucing his brethren, enlargess their sphere of nefulness as well as his own.

We have seen the usefulness of Dr. Grant in (Constantinople, but it was not confined to the capital. At Trebizond he foum 
prejudice argainst Franks so strong that eren the propesty of the English consul hat been destroyed, and one of the misuionaries could scarcely obtain a house to live in; and yet, could he have remained, he would have been welcomed everywhere. So evident was this, that the missionary would have detained him, har he not been needed so much at Oroomiah. When Dr. A. Smith attended an Italian padre at Mosul, one of the people was rerheard saying to another, "The Catholics were very angry recause the Americans came here to do good among us, hut now the padre himself is glad of their services, and the American physician does him all the good he can."

The influence of a pious physician is much more important at the outset of a mission than afterwards. When the missionary comes to be better known, this aid is less necessary, though eren then it is not useless. A missionary in Oroomiah, writing in 1838, after saying that "much has been done, as in former years, in medical practice, and with the like happy effect of conciliating the confidence of all classes," immediately adds, "while our brethren of many other missions have encountered storms of opposition, nothing of the kind has ever yet been organized against us."

Other things, it is true, are to be taken into account in both cases; and yet it is not to be overlooked that Oroomiah and Aintal, the only two stations in western Asia where a physician lail the foumlation, furmis the nost mated examples of sucress. In these two places the work advancel more rapidly, sprear more extensively, and met with fewer obstacles, than anywhere else in the region round about. Says Dr. Lobdell, of the work at Aintab, as late as April, 1852, "If the missionary should refuse to preserithe for the sick, while the people have so much more confitence in him than in the native physicians (and that missionary was not a regular physician), I do not think it would be long before there would he a decline of interest in the great matter of salvation." Thb: fact that an Armenian, not a 
Protestzat, offered Dr. I. one thousum piastres if he would stay and labir there, instead of passing on to Mosul, shows how the matter is viewed by men who have no interest in the truth.

No one, acquainted with the tedious year's of hope deferred, at Smyrna and Constantinople, Broosa and Erzroom, but must be struck with the contrast between them and the two stations referred to. Still, in Syria there are physicians, and not the same progress; perhaps because they were not there at first, to give character to the mission, and, though afterwards useful, they could not regain the ground that had been lost.

Mosul, as we shall see, had to contend with other difficulties; but the advantage of having Dr. Grant there at the outset, even after so long an interval, is still felt by his successors.

We hate seen the physician who prescribed for the Governor of Tabriz selected as likely to meet a more favorable reception at Oromiah than a clergyman. The event proved the wisdom of the selection. Whatever advantage that mission has derived from its excellent location and the general favor of all classes, from the very first, is to be attributed, in no small degree, to the medical services of Dr. Grant. The sympathy of the Nestorians with us, as common opponents of papal errors, needed much tender nursing before it could ripen into sympathy with us as the advocates of a spiritual religion. Ignorance and jealousy, selfishness and the intrigues of those eager to sow the seeds of suspicion, might have clouded the fair dawn of the enterprise, had not the good will secured by such a physician preserved their confidence till it was confirmed by a spiritual appreciation of better things. That the good will of the Moslens was secured at first mainly by Dr. Grant, is testified, with generous candor, hy his excellent colleague, when he says, of the remark of a Persian noble, on their first arrival, "Your coming here is like the rising of the sun upon the world," "The khim, doubtless, alluded to the prospect of temporal benefit from Di. Grant's practice in medicine, and my giving secular instruction." An- 
other of the missionaries salys that, on account of his medical practice, Dr. Grant had had more than twenty times as much intercourse with the Mohammedans as the missionary sent out expressly for them. Not that the physician deserves more credit than the ordained missionary, or that we ought to fix the amount of credit due to different individuals ; but these things: are mentioned that the usefulness of missionary physicians may he appreciated, and that we may see the trials of Dr. Grant, in leaving his children, were not endured for naught.

But the missionary physician is also useful in prolonging the lives of his associates; and, if ever there was a station where a physician was neerled for that purpose, that station is Oroomiah. Situated far in the interior, out of the reach of other educated physicians, it is also peculiarly unhealthy. The great heat ot summer, joined to the abundint irrigation of the plain, and the decaying regetable matter that must abound in a region of so great fertility, produces a malaria exceedingly fruitful in disease ; and, therefore, no small part of the usefulness of Dr. Grant consisted in ministering to his associates in their frequent sickness. That these riews of his usefulness as a physician are not exaggerated, may be seen from the following extract of a letter from the mission, 19th January, 1839, applying for another physician to take his place. Having giren an account of the failure of his health, they proceed to say : "We are now reluctantly constriined, by the exigency of the case, to request you to secure another physician for this mission, to take the flace of Dr. Grant. We are aware that it is difficult to obtain

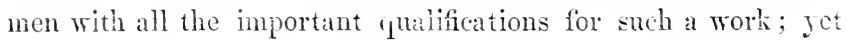
we are fully persuaded that the usefulness of a missionaryphysician in this field will make it an object with the Board to frorme one, at the expense of almost any effort. Whether we regard the impresion made on the Hoslems by Dr. Grant's medical practice, or the almost constant sickness in our own families, we fint the trongest reasons to sustain this opinion. 
The good-will, not only of the Nestorians, but of all classes, has evidently been conciliated by his gratuitous practice, and that without exciting the jealousy even of the native physicians. The prospect of a war between Persia and England, so far from exciting hostility against us, has led to the expression of the most friendly feelings toward all of us, and Dr. Grant in particular; and numbers have expressod a strong desire that we would not leave the country with the officers of the English embassy. We have reason to believe that this feeling is, undei God, to be attributed, in a great measure, to the medical practice of Dr. Grant. We need not remind you that the continuance of such feelings is important to the permanent existence of our mission.

"As respects the importance of a physician to our own families, we do not speak unadrisedly when we say that, on an arerage, half our number have been sick for one-half of the time; and, with the exception of Mr. Holladay, all have been seriously sick during that period; and, though some of us have, from time to time, been raised almost from the brink of the grave, yet our health is being gradually undermined by such frequent siekness We have reason to believe that much depends, in these attacks, on the immediate attention of a physician, and a judicious use of medicine on the first symptoms of disease.

"In conclusion, we cannot forbear to suggest that it may be missionary economy to provide for the health of your missionaries; for, if they sink under the influence of the climate just as they are prepared to be useful [one such had just died], this involves a heavy expense to recruit our ranks, and our lalors, at the same tinie, must be less effective."

The following extracts from a letter of Dr. Perkins to the writer, dated June 15, 1852, need no comment. Spreaking of the early history of the mission, he says:

"No Guropean had resided in this remote Persian town, and the rude and bloody character of its Mussulman inhabitants, of 
the formidable Aftshar tribe, at that time was so notorious that our English friends at Tabriz deemed our enterprise extremely hazardous. Dr. Grant was the man for the place and the period. His personal intrepidity, and his commanding form and mien, - things which so strongly impress orientals, - especially in connection with his skilful practice as a physician, soon won the respect and confilence of all classes, and contributed very materially to our security during the first years of our residence here, and to the permanent success of our mission, - more, doubtless, than any other earthly means or influence. It was not only as bestowed on the natives that his medical services were rery important to our mission. During the first years of our residence here, we ourselves experienced a great amount of sickness, partly from the common process of acclimation, and partly from confinement in a hot city during the entire summer. Under God, he restored me from the rery brink of the grave, when carried thither by a violent and distressing fever, sixteen years ago. For several days I was entirely unconscious. so that, for a time, he despaired of my recovery; but our hearenly Father smiled upon his ceaseless efforts, and raised me up again to life. The little I have been enabled to accomplish during these sixteen years, - indeed, that $I$ have been an inhabitant of sarth, - I owe, instrumentally, to the skill and assiduity of Dr. Grant. Nor am I the only one of our circle decply indebted to him as a physician."

It may not be too much to say, then, that, but for the services of Dr. Grant, the history of the mission to the Nestorians might have been easily written, ending in the sad record of the death of the pioneers, far from the reach of all medical assistance.

Though Dr. Grant left America in excellent health, with a good constitution, and inured to hardship and fatigue, yet in July he was prostrated with intermittent fever; and, before he fairly recovered, the labor and care of attendance on other nembers of the mission, dangerously ill, with other causes, 
induced a severe attack of the cholera, that brought him to the very gates of death. Ile had all the appalling symptoms of a state of collapse in that fatal disease; and, though he was able to direct to the use of remedies blessed to his restoration, his system never fully recovered from the blow. Ever after, his stomach rejected, more or less frequently, every variety of food. Severe neuralgie pains and cramps, the recurrence of intermittent fever, and other effects of the miasma of the plain, were the occasion of almost constant suffering. His own account of their situation that summer, is contained in the following extract of a letter to his mother, dated October 11, 1836 :

"Mr Dearest Mother: * * * * The Lord has been visiting us with sickness for some months past.' I have had two or three attacks of fever, and my eyes have been so inflamed as to require me to bleed and blister freely. Mrs. Perkins and the dear children have also suffered from ophthalmia. Mr. Perkins and the ladies have each had two or three returns of fever. He was so low as to be insensible for several days. At the same time, his little son was so sick with eroup that, several times, we thought he was breathing his last. Providentially, I was able, with much effort, to attend on them; but, on the 16th ult., I was brought to the borders of eternity by a violent attack of cholera. * * * * The Lord, in great merey, has raised us all up again. Let us sing of his loving kindness all the days of our life! Do not think these trials made me doubt whether I was in the path of duty. No, dear mother. While expecting each hour to be my last, I could have testified to the world the excellence of the missionary work. May my dear sons be prepared to more than fill their father's place, and may we all have grace to labor faithfully while we may!"

To his brother he adds, at a later date: "In such eircumstances, for how much of this world do you think I would have 
exchanged my hope in Christ? O, how all its wealth and honors sink into insignificance! But the riches of grace, through the blood of the Lamb, - how rich! how free! All I had ever done or suffered for Christ vanished into nothing, as I thought of what he had done to purchase such peace of mind as I then enjoyed, though raeked with excrueiating pain."

This sickness brought out in prominent relief the excellent qualities of his character. Mr. Perkins had just gone to Tabriz. The whole care of the mission devolved on him; and only women and ehildren were about him, needing his services, rather than able to assist. Yet, though spasms pervaded his whole system, - though his features were sunken, his breath cadaverous, his extremities quite cold and shrivelled, and his voice so hollow as with difficulty to be understood, - he calmly observed every symptom, and prescribed accordingly, at the same time continuing his superintendence of the affitirs of the mission; and though, while recovering from this, ferer and ague set in, yet, four days after the attack, he was able to entertain one of the royal prinees of Persia, - Malèk Kassim Heerzil, not only at his table, but with an examination of the school that, as it was racation time, he had summoned together for the purpose. The prince was highly delighted, and expressed his unqualified commendation of the school, urging the scholars to learn the language and literature of the English, as well as their own. That this was no trifling honor will appear from the fact that a Persian prince never condescends to enter the house of one of his own subjects, whatever his rank; and even the Gorernor of Oroomiah was not allowed to sit down in the presence of this one. It showed, too, some energy of will, as well as strength of constitution, that, in such circumstances, Dr. Grant was able to attend to this and the other duties devolving on him, in the absence of his associate.

These "other duties," in ordinary times, were by no means few or small. Besides his professional labors, - so abundant 
that, in one year from his arrival, he had prescribed for about ten thousand patients, and operated for cataract more than fifty times, - he taught a class in English, instructed his medical student, had the partial supervision of the boys' boarding-school, received and returned the visits of the Mohammedans, had the care of the secular and pecuniary affairs of the mission, and superintended the three village schools, - a work requiring, at that time, a much more vigilant superintendence than now, when the teachers are better educated and more trustworthy. The jealousy of the Moslems, at so much attention being shown to the Nestorians, obliged him, also, to devote a small part of each day to teaching a school for them. The boarding-school was opened Jan. 18, 1836, with seven scholars. The very next day the number increased to seventeen. and as early as May it amounted to forty.

To Dr. Grant, his most interesting labor was the care of a Sabbath-schoul, that commenced on the 24th of Jan., 1836, with some twenty-five scholars, and in July had increased to fifty. In this he had the aid of six teachers, - Mar Yohanna, four priests and a deacon. They met in a large room, forty feet by twenty, without any floor but the earth; the walls built of the same material, and the flat roof covered with the same primitive protection from the weather. The scholars sat on coarse mats, on the floor, as attentive as any Sabbath-school children in America, and recited their lessons, committed to memory from the gospel. These were then explained by their teachers, as they had been instructed by the missionaries. After that, Dr. Grant made practical remarks, as our superintendents do at home, and the whole was closed by singing a psalm in the ancient Syriac. No wonder that he writes, in a postscript to one of his letters, "I regret that all my communications bear the marks of so much haste. But what shall I do? If I write at all, I must do it in a hurry, or neglect other important duties. The preparation of medicine, the care of the sick, of my pupils, 
and the secular affairs of the mission, leave me little more than the night for study. Of that I use as much as I dare, and still I have not enough."

All this pressure of labor, the time necessarily devoted to the acquisition of both Turkish and isriae, and his frequent illness, did not prevent his laboring for Christ in other ways. In Mareh, 1837, he wrote his "Alpeal to Pious Physicians," so extensively circulated as a missionary tract; and his letters to friends in America show that he could find time to plead with the unconverted, comfort the bereaved, and try to train up his children to be holy and useful.

Writing to an imponitent brother, Feb., '36, he says: "I feel the more anxiety for you because of the critical period of life to which you have arrived, and the many temptations around you. If a man settles in life unconverted, the chances are very much against his ever becoming a Christian. "The cares of this world, and the deceitfulness of riches, choke the word, and it becometh unfruitful.' 'The heart set upon the world thinks little of more durable riches. It is so taken up with its earthly habitation, that it thinks little of the 'house not made with hands, eternis! in the heavens.' You have the little Bible which I gave you; and, while I hope it sometimes reminds you of an absent brother, his ardent prayer is that its precious truths may make you wise unto salvation. * * * * Did you know my anxiety, detr brother, on your account, you would not blame me for saying so much."

Writing to his mother and sister, on hearing of the death of his father, May 11, he says: "We had fondly hoped to have welcomed, ere this, a letter from the hand of our dear father; but, instead of that, our first intelligence concerning him is that he is no more. Fain would we have been present to minister at his bed-side, and then mingle our tears with yours; but, as nearly seven months passed away before the news of your bereasement reached our distant home, we had not the privilege 
of sympathizing with you, even in spirit. This is one of the sore trials of the missionary. But we rejoice that you have one Friend, who sticketh eloser than a brother, and who graciously styles himself the God of the widow and fatherless."

Again, writing to his sister on the same subject, June 15, he says: “***** Dear sister, is it not consoling to think, as one after another of our loved ones are taken away, that they have joined the eompany that may, ere long, welcome us also to their blest abode? O, Mary, what a time will that be, when, clothed in a Redeemer's righteousness, we shall sit down with him in his kingdom, to go no more out forever! If we are indeed his, it will be but a few short days ere we shall see him as he is; and we, now so far separated, shall meet those who have gone before us, and mingle our praises with the redeemed from every nation under heaven. Pray, dear sister, that multitudes here may be gathered in through our unworthy instrumentality. O, how much we need the influence of the Spirit of God!"

So intimately in his mind was united "the rest that remaineth" with his earthly toil, he could not think of them apart. His affectionate heart did not soon cease to feel so severe a loss; and, therefore, we are not surprised to hear him, on the anniversary of that bereavement, - Oet. 11, - thus addressing his mother: “* *** How many we loved on earth have gone before us to the mansions prepared by our Redeemer ! And if we, through his rich mercy, are permitted to behold their glory, what a company of those with whom we took sweet counsel in this vale of tears will welcome us to their eternal embrace, and tread with us those golden streets, while, with all the redeemed, we ascribe 'Blessing and honor and glory and power unto him that sitteth upon the throne, and to the Lamb forever.' There will be no more sighs and tears; and there I trust you, my dear mother, will not regret our short separation in this transitory world."

The yearning heart of the father reveals itself in the touch- 
ing simplicity of the two following letters to his absent children, and gives us a glimpse of what it cost him to be separated from them.

\section{"Tabriz, Persia, May 18, 1838.}

"My Dear Hastings: I was told long ago that you had learned to write, and I have wished very much to see a letter from you. Why have you not written to your dear father? I hope you will write very often, and tell me where you are, what you are doing, - whether you have good friends, good books, good schools, good preaching, and whether you and your little brother are good boys. When I get no letters from you, I sometimes fear that you and Edwin will forget your dear father, or that you do not love him and your dear mother as we love you. We think of you and your dear brother, and talk about you, and pray for you, every day; and we love you very much. We feel very anxious that you should both be very good boys, and learn well, and love those who take care of you and instruct you; that you should love your dear father and mother, and your little brother, Henry Martyn; but especially that you should love Jesus Christ, who gives you these friends and every good thing you have, and who gave his precious life to save you from sin. When we hear that you are good boys, we feel very happy; but if we hear that you have been bad boys, and done wickedly, our hearts are very heavy - we feel sad and unhappy.

"You, my dear Hastings, are so much older than your little brother Edwin that you should try to teach him to be a good boy, and do what will please God and your dear parents and friends. You must teach him by your example, as well as by your words. For, if he should see you do wrong, he will not mind when you tell him that he must be a good boy. If he sees you neglect what your good teachers and friends tell you, or sees you play on the Sabbath, or take things without liberty, he will very lik əly do wickedly too. If he hears you use bad lan. 
guage, or tell lies, I fear he will do so also. But, if you always do right, you will teach your little brother to do right too; and thus you will do good, please God and your friends. I have written to your Uncle Ira and Mr. Shaw to provide good friends and a good home for you, so that you may learn well, and be prepared to do good to others. But you must always look to God, your heavenly Father, to take eare of you. He says in his word, 'They that seet: the Lord shall not want any good thing.' 'Seek first the kingdom of God and his righteousness, and all these things shall be added unto you.' Do you remember that when the Lord asked Solomon what he should give him, Solomon asked the Lord for an understanding heart; and God was pleased, and gave him wisdom, riches and honor? Now you, my dear son, should pray for an understanding heart, that you may be wise and good, and then you will be happy."

In the same letter he says: "I hope that the follower's of Him who haul not where to lay his head will think less of accumulating wealth, and more of using it for the spread of the gospel. When will Christians, bought with a Saviour's blood, learn to lay up their treasures in heaven? $O$, to see as much anxiety for investing funds in the conversion of the world to God as in railroads and bank-stock! If Christians felt the blessedness of living wholly for God, what a different state of things should we see in the church! I feel more and more that, ere the world is converted, Christians must come up to a higher and holier standard of consecration to God. They must feel that the great business of life is to be co-workers with Jesus Christ, in saving this lost world. Instand of taxing every energy of soul and body to heap together a little shining dust, their daily inquiry should be, What can I do to honor my Saviour, and save my dying fellowmen from sin? These are motives worthy of the powers of Gabriel, and they should be first in our minds when we lie down and when we rise up. We should earry them to our daily toil ; 
we should feel that our time, our property, our influence, our children, all belong to God. We are not our own.

"I hope that you and Edwin may come out here as missionaries, if you are good boys. It would be a most happy meeting for us all, if I could see you devoted to the service of God in this distant land. We pray that this may be the case, - that you will seek, first of all, the kingdom of God and his righteousness, and live to his glory. Pray much for your dear father and mother, and little Henry, that the Lord may spare our lives, and make us very useful in his service. Give our love to all our friends who inquire respecting us.

"From your ever affectionate father,

"Asahed Grant."

"Mr Dear Edwin : Do you remember your dear father? It is a long time since you have seen me. You were then a very little boy. I think you are now much larger, and know much more than when I left you. I am haply to hear that you can read. I hope you love to read good books; they will make you wise and good. Do you love to read the word of God? That is the best of all books. I wish very much to see you, and I wish you could see your dear mother, and your little brother, Henry Martyn. He is very small yet. He rums about the house and the door-yard, and talks a little, but not very plain. He was sick a long time, and we feared he would die. But God was very good to him, and he is now very well. Your dear mother thinks he looks like you. She has fourteen little girls to teach. When we came to Persia none of the little girls knew how to read; but now some of them are learning. I hope that all the little boys and girls will learn to read, and learn to love God. I hope you love Jesus Christ, and pray to him very often. Will you not pray every day for your dear father, mother and brothers? You must love your teachers, and the dear friends who take care of you. Remember that 
Christ is your best friend. That you may love him, do everything to please him, and be very happy, is the daily prayer of "Your ever affectionate father,

\section{"Asainel Grant."}

The "little brother" referred to in the last was born on the $3 \mathrm{~d}$ of June, 1836, and suffered much in his infancy from the climate, that proved fatal to so many of his playmates on the mission premises.

The following extract from a letter to his brother Ira, Oct. 26,1837 , reveals something of his trials with reference to his children :

“* * * My great desire for my dear sons is that they may be entirely the Lord's. You say that Mr. Shaw, after much effort to obtain for them a home, found none willing to assume so responsible a charge ( $\mathrm{Mr}$. Smith, with whom he left them, had died). Were all, then, willing to assume the responsibility of leaving those little orphans without a home? Would Christians, who might train them up for God, be free from guilt, if, through their negleet, they grew up in sin? Or would they be blameless, with regard to the perishing here, if, for the same reason, it beeame my duty to return to take charge of them? What if, when a fellow-missionary lay dangerously sick, I should refuse the responsibility of prescribing for him? Would I not he held to answer for his death? And yet, how often are Christians unwilling to assume the responsibility of doing a thing they know ought to be done, without thinking of the greater responsibility of leaving it undone! A Christian cannot free himself from responsibility in any question of duty that comes before him. For his decision in each he is accountable to God. If the path of duty is not clear, we must obtain light, then decide. I know the responsibility was great in my deciding to come to Persia; but wonld it have been less, had I decided not to come? That was a burden I dared not assume, 
Where duty is plain, a man cannot hope that he is a Christian, if he refuses to do it. If our hearts were wholly given to God, we should feel that all we could do for the kingdom of Christ was our dearest privilege, and that word would take the place of duty in our religious rocabulary."

In the beginning of $1837 \mathrm{Dr}$. Grant suffered again, through over-exertion while still wak from previous illness. Mr. I'erkins was yet unable to labor, and, as he could not bear to see their efforts suspended, he stagrered on under too great a burden till his ascociate was able to resume his duties. Then overwrought nature gave way, and for five weeks he was scarce able to leave the house. But soon he says, with his accustomed cheerfulness, "Through the mercy of God we are all able to engage again in our increasingly interesting work."

Still his health needed to be confirmed, and to this end he devoted more time to labors in the surrounding villages. In one of these excursions, - June 24, 1837, - he visited the ruins of Gugerchine castle, four hours north-east of Gavalan. They are on an insulated cliff, that rises abruptly from the lake about eight hundred feet, and can be reached only by a winding path cut out of the rock, that passes over two drawbridges at a giddy elevation. The low neck of land which joins it to the shore is fortified by a wall and fosse, and on the summit deep carerns are found among the ruins. A spring gushing from the side of the cliff furnished an abundant supply of water for this stronghold of former days.

On the 12 th of July he visited, for the second time, the Kurdiwh chief, of Burdasoor, at his castle, nearly six hours west of Oroomiah. This is perched on a projecting rock, several humdred feet above the river that foams below. Its thick stone walls, ample reservoir, magazine, subterranean passage, and the wild mountain scenery around, must hare prepared him for his future wanderings in Kurdistan. The chief received him very 
kindly, and urged him to bring his family to reside for a time in the castle.

That these excursions were not always without danger will appear from the following adventure at Ada, November 11, 1836. Mr. Perkins and Dr. Grant, with their wives and Priest Abraham, were walking quietly through the village, they had just left the house of Mar Yoosuf, whose guests they were, - when three ruffians, of a class called Lootee, placed a horse across their path to provoke an affray. The thick hedge prevented their going round it, and Priest Abraham stepped forward, mildly requesting them to remove it. Their only answer was an attempt to stab him. Seeing the inoffensive, priest in such danger, $\mathrm{Mr}$. Perkins instinctively sprang forward, and the assassin at once turned on him. Nothing but the providential fall of Mr. Perkins at the moment saved him from instant death. As it was, the dagger cut through his clothes and punctured his side, without, however, inflicting serious injury. Seeing his associate thus hard beset, Dr. Grant, who was behind, flew to the rescue, and, unarmed as he was, drew his riding-whip with such good effect across the villain's eyes as to turn his fury in another direction. In the subsequent confusion, the whole party escaped into a house; and, besides Mr. Perkins, the priest was the only other person injured. The timely interference of Dr. Grant doubtless saved the valuable life of Mr. Perkins. He writes to his sons afterwards, from Mosul, "Have you got the riding-whip, with a deep cut in it near the handle, which I sent you in the box? That cut was probably the means of preserving the life of Mr. Perkins. The fact of my running to his rescue was entered on the mission records, under his direction; so please keep the whip as a memento of the occurrence."

The whole affair was overruled, by the God they served, to their greater security in that land of violence; for, through the efforts of the British ambassador, the Lootee received such a 
chastisement from the Persian authorities as made people careful how they injured any member of the mission.

If Dr. Grant was abundant in labors, so was his companion. She was able to commence her missionary work, as soon as she arrived, with the ecclesiastics who had learned English with Mr. Perkins at Tabriz; and now appeared the good fruits of her thorough education. The bishops in her family - Mar Yohanna and Mar Yoosuf - wondered to see a woman learning Syriac through the Latin; and got new ideas of female worth when, reading together in the New Testament, she turned to the Greek for the meaning of some difficult passage. It may be questioned whether the impressions they received, as they sat at her table and marked the Christ-like spirit that governed all her conduct, did not prepare the way for the unheard-of experiment of a girls' sehool, as much as her untiring efforts did for its establishment. For, finding it impossible to begin sueh a school at once, owing to the prejudices of the people, she first taught her own domestics to read, and then sought to interest her own sex in the education of their daughters. She succeeded so well in this, that at length the desire of her heart was gratified in the establishment of a female seminary. Of this she was the first teacher, and with such ardor did she engage in the work, that, when unable to leave her chamber, she had the scholars assemble there; for hers was a zeal that even sickness could not abate. The female seminary, since so blessed under the superintendence of Misses Fisk and Rice, opened on the 12th of March, 1838, with four pupils. In the course of two weeks, so favorable was the impression she made, that the number doubled, and before the 19th of June she had forr times as many as at first.

As early as January, 1836, she had written to a friend: "I do not know how the Nestorians would regard efforts for the instruction of girls, as they are valued only in proportion to the $n$.oney they earn; but Mrs. Perkins and I intend to 
make the experiment. If we can be but the means of elucating one or two, who can calculate the rast amount of good we might accomplish? Great watchfulness and circumspection are necessary to this object, as example is a much better teacher than precept. There is no danger of our setting too bright an example of Christianity."

She had readily learned to speak the Turkish, and in a short time was able to read the ancient Syriac. The modern Syriac, irregular as it is, she not only read, but wrote also. When Parley's Geography was translated by Mr. Perkins, she prepared the maps for it; and taught a class in Woodbridge's Geography, in which Priest Abraham, John and a promising deacon, were added to the bishops, and her Mohammedan pupil, Meerza Asiad Ullah.

In one of her letters she gives us a glimpse of the interior life of the mission, telling us of the Bible-class on Monday and Saturday evenings, when the missionaries and their native helpers studied together the word of life. On Tuestay evenings, the former met together for mutual consultation. And then there were their reünions twice a week, begun Nov. 6, 1837, when the natives presented their English sentences for criticism to the missionaries, and then criticized, in turn, the Syriac of their teachers. Thursday evening was devoted to a prayermeeting; and on Sabbath, after two religious services in Syriac and one in English, they met together with the Nestorians to sing the Lord's songs in that strange land, which yet to them was not strange, for it was their chosen home, a land they loved. Mrs. Grant, though suffering, like her husband, from the climate, yet writes to her friends, June 1, 1837, "I think I can say, sincerely, the two past years have been the happiest of my life, and nothing but imperious necessity could ever induce me to leave Oroomiah." Dec. 26, 1838, in a letter she did not live to finish, after telling that not long before the doctor prescribed for ten of their number in one day, and that 
her left eye was destroyed by a severe attack of ophthalmia, she adds, "But, through the great goodness of God, one eye still continues strong. $O$ for a heart to praise Him !" While her husband kept up his old habits of reading, as time permitted, she honored her mother's training in reading with him " Maeulloch on Malaria," as well as more pleasant, if not more interesting volumes.

But her lahors were not mere literary efforts. The medical practice of her husband - I had almost said her own - introduced her among all classes; and, welcomed by her own sex alike in the palace and the beggar's hut, she went about doing good. If it is interesting to see Nestorian bishops instructed by her out of the Scriptures, as was Apollos once by the good Priseilla, it were no less so to follow her into the homes of her degraded sex in Persia, and see her work of faith and labor of love. No trait in her character was more conspicuous than her skill in the sick chamber. Which of her suffering associates could not join the pioneer of the mission, and say, "Like Mercy's angel, we beheld her hastening from room to room, when several of us were sick at once. Like her Master, she went about doing good." Still, amid such a variety of cares, her household affairs were not negleeted; everything moved on in quiet regularity, and, as others looked on her attentions to her little son and twin-daughters, and also to the three native children of whom she had the eare, they wondered how, with her weak health, she ever found time for anything else. But, with all these labors, her only hope for success was in God. Writing to Mr. Merrick, March 7,1836 , she says, "I am every day more and more convinced that this is a most dreadfully wicked country; nothing but the almighty power of God can produce a change for the better." 


\section{H A P T E R V I.}

INTEREST IN THE MOUNTANS - CORRESPONDENCE WITH COL. SHEIL AND DR. RIACH - SCHULTZ-FAILURE OF HEALTH - DEATH OF MRS. GRANT POLITICS OF KURDISTAN.

Dr. Grant was deeply interested in the Nestorians of the mountains, even before he left America. The importance of that field, and its difficulty, were just the things to recommend it to his enterprising spirit. In a communication to Dr. Anderson, dated Nov. 15, 1837, he says: "When I first looked on th:is as my field of labor, the brightest beams of hope seemed to radiate from the mountains. I felt it of the utmost importance to enter them as soon as possible; and the hope that my knowledge of medicine would enable me to meet danger with more impunity than others, was one of the strongest motives to my coming. From that day to this, I have kept the subject continually before me, and its importance has by no means diminished in my mind, as a means of reviving the Nestorian church, and evangelizing the whole region around." No mountaineer visited the city but knew these feelings, and loved him for them; and no Kûrd ever came for medicine who was not made to contribute some information for future use in the enterprise. For three years Dr. Grant laid siege to the mountains, encamped at their base, watching for the first available point of access to their unknown interior. Like John Williams, on the other side of the globe, he felt that he could not be confined within the limits of a single reef while the wide ocean lay before him.

Perhaps it was well that some in the mission were as prudent 
as he was ardent; for He who wisely composes the church at home of men of difierent ages and temperaments does not leave missions to one-sided influences, but sets one thing over against another, that, by a proper balance, he may secure the highest good. Perhaps, by himself, Dr. Grant would have entered too soon, as others night have deferred too long. But God used discouragenents to render his purpose firmer; and, when it had grown strong enough to bear the hunger and weariness, the pain and the peril, before it, then he led him into the theatre for which he had been training him from the first.

And here let us liear the testimony of his earliest associate in the field. Says Mr. Perkins, in the letter to the writer already ynoted, "If Dr. Grant's holy cnthusiasm, either in the anticipation or prosecution of that difficult and perilous enterprise, sometimes got the better of his judgment in teo zealously pressing forward the work, or too fondly embracing his cherished theory, it was owing to his quenchless ardor in the cause of Christ, of which, in most missionaries even, we see far too little. If that enthusiasm erer amounted to a futt, we can easily excuse it, so strongly did it lean to virtue's side. It was the outburst of a great heart yearning and throbbing agonizingly orer the mournful desolations of those he verily believed to be heirs of salvation according to the promise."

As early as Dee, 1835, an aged priest, from near Julamerk, and an uncle of Mar Shimon, dined with the mission in Oroomiah. In the following February Dr. Grant enjoyed his first interview with a brother of Mar Shimon; and, in April of the same year, he had a visit from Selim, Kûrdish Pasha of Amadieh, the brother of Ismael, of whom we shall hear again. On the 26th of March Mr. Perkins had written a friendly letter to Mar Shimon, and just two months later he received an answer, equally friendly, begging a watch, and requesting to know at what time he would visit him, that he might send a guard to protect him from the Kûrds. 
July 1, Dr. Grant wrote to the Prudential Conmittee, urging the importance of entering the mountains as soon as practicable, because they formed a part of the field assigned to the mission, and the main body of the people was there. The variations in the spoken language rendered an acquaintance with all its dialects desirable before translating the Scriptures, or even publishing tracts in it for the people. The work should progress in all parts of the field at once, that a common sympathy might pervade the whole, and one part not advance alone in intelligence, so as to become an object of suspicion to the other. The Patriarch, too, resided in the mountains; and it was important that he should not be left behind in the movement of the clergy and people on the plain. There was no telling what mischief might arise, should enemies get in before us, and fill his ear with slander before he had become acquainted for himself with our principles and plans; and it was not to be supposed that Papists, who strained every nerve to oppose us on the plain, and were already posted on the other side of the mountains, would delay to operate against us there.

These arguments left no doubt of the desirableness of the undertaking. Each subsequent page of the history of the mission commends the far-seeing wisdom that pereeived them at that early day. It does not become us to find fault with events as Providence has arranged them; and yet, had Mar Shimon been brought carlier under the influence of the evangelical movement in Oroomiah, his situation might have been a more happy one to-day. Or had Rome got possession of a position not only commanding, but looking down into ours on the plain, it is easy to see at what a disadvantage we must ever after have fought the good fight of fith. When Dr. Grant saw how Providence had mercifully preserved the mountaineers from the enemy till he had brought us, as it were, on purpose for their deliverance, his soul was grieved at every day's delay: he longed to fly to their help at once. 
But, though the desirableness of the enterprise was established, the great question remained, Is it practicable? Messrs. Smith and Dwight were deterred, by representations of its impracticability, from entering the mountains in 1830 . Mr. Perkins was instructed by the Board, in September, 1833, to " visit the Patriarch as soon as may be, lest perverse men should prejudice his mind against you;" and, accordingly, Dr. Grant set himself to work to ascertain, as accurately as might be, the perils of the enterprise, and see whether or no they were really an insurmountable objection. He longed to enter; but, according to an old adage, he would look before he leaped.

He had already written to $\mathrm{Mr}$. Dwight, and received an answer, dated Sept. 6, 1836, in which he says: "I consider the object a very important one; and, were I in your situation, would certainly try hard to secure it. And yet, I would not run great risk for the sake of going immediately. Your being a physician would, doubtless, be of great advantage in the undertaking."

As the ground had never been gone over by any European, it was, of course, impossible to gain information from such. The only way was to make inquiries of such mountaineers as he met with, the Persian authorities conversant with that region, and such European travellers as had gone nearest the route in question. While he made unceasing inquiries of the two former classes, one of the latter was fortunately within reach; and to him - Col. Sheil, brother of the eelebrated member of Parliament - he addressed a letter, inquiring whether he considered it unsafe to visit Tyary, and stating that Mar Shimon had invited him to visit him, and promised him a guard through the country of the Kûrds; that he had ascertained he could go the nsual route, through the Hakkary country, in three days, and sleep each night in a Christian village; or a more southern one, through Burdasoor, where the chief was his friend, and would protect him to Mar Beeshoo, a Nestorian village, only foriteen 
hours from the Patriarch. He asks whether he would advise him to accept the invitation of Mar Shimon, and confide in his promise of a guard. Col. Sheil replied, June 22.2 :

" For myself, I should not hesitate a moment to visit Tyary with a guard from Mar Shimon, and would feel perfectly safe in doing so. But, in your anse, much would depend on the feelings of the priesthood toward your labors [Col. S. was an Irish Catholic]. With the protection of the chiefs you mention, I should say there was no danger whatever in the undertaking. The journey is practicable, beyond a doubt, and the danger not very great, - much less, I presume, than you anticipate."

Such was the encouraging reply of the fearless colonel, whose kindness to Dr. Grant neither begun nor ended here. But, so nuch had been said of the madness of the_undertaking, that, in October, he wrote to his good friend Dr. Riach for his opinion of the matter. The reply of the "canny Scot" was much more cautious than that of the Irish soldier. He begins by saying that no European can travel there without danger; yet there is little prospect of its being removed for a long time to come. But - and it is amusing to see how carefully he considers the matter - if, just before entering, the Hakkary country is quiet ; if Yahya Khan, of Salmas, offers a guard, and pledges your safety; if the Kürds were as well disposed to Persia as they now are, and the Persian authorities gave letters to Yahya Khan calling on him to protect you; if, besides the guard from him, you have one also from Mar Shimon; and if your baggage is so scanty as not to excite the cupidity of the Kurds; - if all or most of these circumstances were combined, I should think there was considerable prospect of safety to a judicious person. He closes with the remark, "I feel much more strongly than ever that your mission must be brought into contact with the Mountain Nestorians." With all its caution, it will be seen that his letter is eminently 
judicious. The good man - who, in July, had gone tro hundred miles out of his way to visit the missionaries, and cheer them in their work - evidently felt an affectionate solicitude for the safety of his professional brother, and, at the same time, was anxious that the journey should be performed.

Immediately on the receipt of this, - Nov. 15, - Dr. Grant wrote to the committee; and, after reviewing what has just been made known to the reader, he says: "The letter of Dr. Riach is characterized by candor and caution. I fully agree with him that we cannot soon hope for a change that will render the undertaking entirely safe. For centuries the Kurds have been the same wild marauders. Last year Reschid Pasha subdued a part of Kûrdistan ; but none in modern times have penetrated to the Hakkary country, nor is there any speedy prospect that it will be done. Numerous as are the doctor's conditions, they might almost all be met at once. As for guards, I would like one or two guides from Yahya Khan; but I would sooner trust to the coarse garb of the mountaineers, and that frankness and kind feeling that commend themselves even to the savage, than to a regiment of soldiers. When the attempt will be made depends on the majority of the mission and your instructions. In my last I expressed the opinion that, as repeated illness had prevented that progress in the language that was desirable, the attempt should be deferred till another year.

"Whoever goes should spend several months in familiar intercourse with the people by the wayside, and in their smoky huts. He should win their confidence by unwearied kindness, and study their character and institutions under the varied circumstanees of their wild mountain-life. As to the number that should go: On the one hand, he might feel lonely, and in need of counsel, - he would also feel the want of help in sickness; but, on the other, one would attract less notice, and, in case of violent death, the loss to the mission would be less serious. 
Much has been said of the fate of Schultz; but we may make too much of a single case, without a carreful consideration of the cireumstances. I have taken pains to learn the facts in the case, and both Turks and Persians agree that he made an injudicious show of wealth. He was the agent of a Luropean monareh, carried various astronomical instruments, had a great deal of baggage, and made splendid gifț to the Kûrdish chiefs. They naturally thought his boxes were full of money, and suspected that he was surveying their country for his king; therefore the wonder is not that he fell at last, but that he eseaped so long. Again, this is the only attempt to enter the mountains; and had Mr. Samuel, who was robbed between here and Tabriz, been the only European who had visited Oroomiah, the road, doubtless, would be considered very perilous, especially when taken in eonnection with the eighty murders committed in the province within eight months.

"In conclusion, I would repeat my sense of the great importance of the undertaking; and, unless prevented by unexpeeted providences, I stand ready for all the perils of the entcrprise. I have felt it duty to lay the subject thus fully before you, with the reasons for my views, that, if the attempt be not made, the responsibility may not be mine. I would not defeat the object by undue haste; but, with the evidence before you, would it be an unwarranted exposure of life to make the attempt at an early day, should nothing extraordinary prevent? Admitting that there is danger, does our commission guarantee exemption from it? Does the experience of Paul warrant us to expect it? I look on this journey as the first step to more extended usefulness, and a wider diffusion of the gospel."

The reader will pardon this minuteness of detail; but, when, on the one hand, Dr. Grant is charged with "courting death at every step," and, on the other, his journey into the mountains is sneered at as an every-day affair, justice to the memory of a good man requires that things be stated just as they occurred. 
He did not take a single step till he had earefully reconnoitred the whole ground. 'The event showed the wislom of his plan, and justified the zeal that pursued it so long and so steadily.

But the time for the attempt was not yet. A reinforcement must first arrive to strengthen the mission, and a larger experience must fit him for the work. It may secm strange, but is nevertheless true, that the loss of his health, so as, at one time, to excite serious apprehensions for his life, was one of the means employed by Providence to open for him this new sphere of usefulness. The diseased action of his stomach, already referred to, continued steadily to increase. He did not retain food long enough to impart nourishment to the system, and his strength was so prostrated that he once fainted when rising in a social meeting to engage in prayer. He managed to live only as he left the eity, and rode to the purer air of the distant villages. Uniformly, while absent from Oroomiah, his health improved, and as often as he returned it grew worse. He went to Tabriz in February, 1838; and, though worse than usual before he left, did not romit once during an absence of three weeks. He spent his time there with his dear friend Dr. Riach, who was horror-struck at the change wrought in the hale, robust man he had welcomed there not three years before; yet he had the satisfaction of seeing that his color returned, and that he gained in flesh, and improved in every respect, while with him. He returned to Oroomiah, and again relapsed. Inmediately on hearing of this, Dr. Riach wrote to the mission that they nust apply for another physician; and suggested that his labors for the Nestorians need not terminate, as the mountains ought to be explored, and all knew that he was just the man for that work. -In the spring Dr. Grant superintended the village schools, which had now increased to twelve, in as many different villages, and in doing so had ridden about five hundred miles since his return from Tabriz, - still vomiting, more or less, every day. On April 14 he wrote to the committee, giving an account of 
his health; expressing the fear that, unless the measures he was then pursuing should prove successful, his constitution would not hold out longer than another year in the miasma of Oroomiah. He adds: "I often wonder that $I$ am able to sustain so much fatigue, and am thankful that it is so, as my hopes of prolonged life and usefulness depend upon it. The question becomes a very serious one, What shall be done? I am most deeply interested in the Nestorians, and know of no other people on earth with whom I would prefer to spend the remainder of my days. Indeed, it would be like parting with life to give up the hope of performing some humble part in fitting them to spread the gospel over these regions of darkness and death. Nothing but the clearest convictions of duty will ever induce me to leare my post. But, if my usefunness here must end either by death or a removal from this station, whether, in that case, I must see all my fond hopes of usefulness among this people blasted, I must submit, under God, to the Prudential Committee."

At this period the pressure of 1837 was just beginning to be felt in Oroomiah. It crippled every department of missionary effort; and, amid the disbanding of schools and dismission of native helpers, the invalid hardly dared to incur expense for the restoration of his failing health. But business requiring that some one should go to Tabriz, he went, and again experienced relief. His religious feelings at this time are sweetly described in a letter to Mr. Stocking, dated May 23, at Tabriz:

"Truly we have great occasion for gratitude in the rich mercies of our heavenly Father. Let us evince it by untiring efforts to do his will in all things. We need the spirit of obedient children, striving at all times to please a kind Parent, and more afraid of his displeasure than of anything else. How kind God is, when his children go astray, to bring them back by the rod of correction! Surely he has designs of mercy in afflicting our mission so much with sickness. He intends, first, to make us partakers of his holiness; and, when he has thus prepared us 
for his service, I trust he will pour us out a blessing. He will first bless our own souls, and then make us blessings to others. $O$, that we may all be blessings to each other, and, by our holy conversation and godliness, incite each other to fidelity in our Naster's work! We need the unction of the Holy Spirit; and we may have it, and thus do more in a few months or years than in a long life without it. How much more anxious should we be for His presence than for health or long life! Jeet us feel that Christ is our life, and our great concern will be to have him dwelling in us, the hope of glory."

He returned to Oroomiah, only to relapse again, with every symptom more obstinate, and threatcning permanent organic disease. Writing on the subject to his mother, he says, Oet. 9, 1838 , "It is doubtless the effect of a hostile climate, and occasions much suffering; but I do not mind that, while I have strength to labor, as I have most of the time. What the result will be is known only to our heavenly Father, and I rejoice that $\mathrm{He}$ will order all things well. I do not feel anxious for the future, or whether my work be long eontinued, provided it is well done. I trust I feel willing to do or to suffer the will of God; and, blessed be his name, there remaineth a rest to his people where shall be no more death, neither sorrow nor crying; neither shall there be any more pain." Alluding to the exeellent history of the missions of the Nestorians, in the Herald for August, he expresses his joy that those once so active in spreading the gospel through the world were now receiving such instruction as by the blessing of God, might prepare them again to send forth heralds of salvation, and adds, "Let me but have some humble part in this glorious work, and I shall not have come here in vain, though my staly here be but short. You may ask whether now I regret entering on the work. No, never. I often feel keenly my absence from dear ones at home, - yes, home; the thought revives a thousand hallowed recolleetions of maternal love. But we hope to meet in happier mansions, even 
those which Jesus has gone to prepare." On the 20th of August the mission passed a resolution concurring in the opinion of Dr. Riach, that as a continued residence in Oroomiah was so dangerous for Dr. Grant, it was expedient that, as soon as possible, he seek a more favorable climate; and on the 19th of January, 1839, they male formal application for another physician to take his place.

Just before this was done, Dr. Grant was called to suffer a greater loss than he had yet endured; for the loss of a loved companion at home is not to be compared with the same loss in a foreign land. Mrs. Grant was taken sick of a violent fever on the $3 \mathrm{~d}$; and, notwithstanding all that skill or affeetion could derise, she died on the 14th of January, 1839, aged twenty-five years and two days. It is hardly necessary to say that on her death-bed there were no regrets for having become a missionary; and that she rejoiced to lay her body, far from those of her friends, among the people for whom she had loved to live. On the erening of the 6 th she spoke with much feeling to her associates on being wholly the Lord's, and having their conversation in heaven; for, from the first, she did not expect to recover. Enfeebled by disease, and doubtless no less worn out by sympathy with the sufferings of her husband, she felt that she could not survive. At one time she said, "To think of dying and being free from sin and suffering, in the presence of God, is most delightful. It is rapturous!" But said she, again, "It is all through grace, grace, grace. I renounce myself entirely. It is through the riches of God's mercy in Christ Jesus that I shall enter heaven." Her life, especially after her conversion, seemed so black and odious, she could not bear to look on it; but when her husband spoke of the righteousness of Christ as all-sufficient, "Yes," she replied, " He is my all - my all!" Speaking to him of their approaching separation, she said, "It will be but for a little while. What a happy meeting that will be! - all tears wiped from every eye, and no more death." 
The prospect of meeting Christ gave her more joy than all else. "I used to think much of meeting my dear mother and Christian friends, and still it is precious to know they will be there. But it seems to me the presence and glory of Christ will so absorb me, I shall wish to think of nothing else." She felt unworthy to suffer for Christ, and longed to be more worthy of such a privilege.

From the first, her only anxiety about the result was that God might be glorified. In taking leave of the bishops and others connected with the mission, she told them she was about to leave them and go to heaven, and earnestly desired them to meet her there, adding, "If I have one desire to live, it is for the sake of you and your people. For myself, I am ready to depart; not on account of any good works of mine, but only through faith in Christ and his righteousness. He is all my hope, and must be yours also, if you would meet me in heaven." It was a scene never to be forgotten. All were in tears; and some wept aloud, entirely overcome with grief. Most had been her pupils, and witnessed her untiring efforts for their salvation. They knew that for this she had left all dear to her at home; and now, as they witnessed, for the first time, the power of the gospel in a dying hour, a subdued and tender spirit of inquiry was awakened, and the missionaries found it easier to preach Christ and salvation through his blood than ever before.

From the day of this interview, she was delirious till her death; sometimes fancying herself again with the playmates of her youth, sometimes in her family, and again absorbed in anticipation of hearen, till she entered there.

During her sickness, all classes manifested the utmost desire for her recovery. A venerable bishop, residing some miles distant, was so anxious for her that he stayed on the mission premises several days and nights. "In the church," one of them said, "after our usual prayers, we all kneeled down and 
prayed from our hearts that she might be spared." The Mohammedan Meerza, who had lived in her family, to use his own words, "could not sleep at night," and wept like a child, in apprehension of the event. Afterwards he said, "I know why she did not fear to die; she had faith in Jesus. She has gone to Paradise." Was not this kind interest of the people for whose sake she had left home and friends something of the hundredfold promised to such even in the present lifi?

The morning after her death, several of the bishops said to Dr. Grant, "We will bury her in the church, where none but holy men are buried. She has done so much for us, we want the privilege of doing something for her, and will dig her grave with our own hands." More than all clse she had desired that her death might be the means of salvation to the Nestorians; and eternity alone will show how much connection it had with the subsequent revivals in that interesting field.

Two days after her death, Dr. Grant thus wrote to the missionary with whom they had travelled together from Constantinople to Tabriz :

" " The chamber where the good man meets his fate

Is privileged beyond the common walks

Of virtuous life, quite on the rerge of heaven.'

"Such, dear brother, is the room you so recently oceupied in our happy home. Our much-loved Judith is released from toil and suffering on earth, to join the glorious company before the throne, where "shall be no more death, neither sorrow nor crying; neither shall there be any more pain.' There she lies, lovely even in death, - that familiar smile upon her features, the last impress of Heaven's seal. The voice, silent here, wakes in louder, sweeter strains anid the anthems of the skies. Dear brother, I know you will weep as I have wept, but not for her. She was ready for her summons. She had committed her precious babes, and all she held dear on earth, to her Saviour, with the sweetrist assurance that he would do all things well. 
"The bridegroom found her with her lamp trimmed and burning, and waiting for her Lord. Death had no terrors to her. She looked on him as a messenger sent to call her home. With inexpressible delight she exclaimed, ' $O$ the presence of Christ! It is everything! It is heacen to the Christian, and the Lumb is the light thereof!' For more than a week hefore her death, he began, with the utmost composure, to set her house in order; she charged me to tell her friends she never regretted coming to Persia as a missionary ; and asked the prayers of the mission, that God would glorify himself in the event. The glory of God was her great desire through her whole sickness, and she felt she could die most cheerfully for such a result. She spoke very feelingly of her firiends, and more than once of yourself. $\mathbf{O}$, let us live, dear brother, entirely for the glory of God, and then our sojourn here will indeed appear short, very short; and, when released from earthly toil, like the lonely wanderer, we shall feel inexpressible happiness in the view of home - an eternal home! What a blessed truth, there remaineth, therefore, a rest for the people of God! Think of your departed sister as now enjoying that rest in the presence of the Saviour so dear to her, who is waiting to welcome us to the same glorious abode.

"She suffered much in her sickness last summer. But God does not cast his children into the furnace for nothing. He was thus preparing her for his own immediate presence; and, however severe our trials, they are not worthy to be compared with the glory which will be revealed in us, if we are indeed the sons of God. To be like Christ - what a thought !

"Mrs. Stocking, at their mother's request, has taken our dear children, and perhaps I shall board with them for the present. Can you not come and occupy my house with me? I need not say you will be welcomed more cordially than ever by those of us who remain; but you will miss the cordial pressure of one warm hand. Is it too much to say that the flower of our eircle has been taken? Such, at least, is the feel- 
ing of the Nestorians. God knew which of us to take, in order to affect them most deeply. I never knew such deep solemnity among them before. May it result in a glorious effusion of the Holy Spirit!"

Her children, Henry Martyn, now two years and seven months old, and the twin daughters, five months old, were kindly taken care of by other families of the mission; and her husband, with his illness aggravated by this sore bereavement, again found refuge in Tabriz, where his recovery was much slower than nn previous visits. While there he secured Russian protection for the mission, as the English ambassador expected soon to leave, and procured a firman for an out-station at Gavalan.

Through the kindness of Malek Kassim Meerza, he had also procured the following rakam (edict) from the Emir En Nizam, Governor-general of Aderbijan :

"TO HIS IIIGHNESS YAHYA KHAN, GOVERNOR OF SALMAS, A ROYAL FAVORITE AND GREATLY ESTEEMED :

"His honor, the learned Dr. Grant, proposes to travel in the country of the Hakarees and that vicinity. To the royal favorite it is written, that in the manner which may be necessary he bestow on Dr. Grant the attention of warm friendship, and send two or three persons to be with him during his travels, and with the greatest diligence take care of him, so that in no manner of way any harm approach him, that in the greatest security and safety he may return, and that he may take with him of his fellow-citizens whomsoever he pleases, it being obligatory that you command his attendants not to hinder his having associates, and that they be strictly attentive that no vexation nor trouble hap pen to either $\mathrm{D}_{\mathrm{i}}$. Grant or his associates.

"Given in Zoo el Hhadeth el Haram, 1254 A. н."

He was now utterly at a loss what to do. On the one hand, his children at home needed his presence. The guardian with 
whom he left them had died, as we have seen, in 1836. His own father, on whom the eare of them then devolved, had died the year before. A younger brother, on whom he next depended, also died in 1837 ; and now his only surviving brother and Rev. Mr. Shaw had the temporary care of them. His children at Oroomiah, too, needed attention. The mission families were feeble, and pressed with the eare of their own. And yet, on the other hand, how could he tear himself away from the work at this critical period, when the goal so long sought was almost in sight? He again proposed to the committee to go into the mountains and collect all the information possible, before returning with his children ; then stay about a year in America, recover his health, provide places for them, and again go back to the mountains. But, before he had finished the letter, word came from Mr. Homes, at Constantinople, that the committee had appointed them to go into Mesopotamia and Kûrdistan, and fix on a station whither Dr. Grant should remove with his family, and Mr. Homes stay till a reinforcement should arrive.

It was by this time past the middle of February, and the bereaved husband, now sadly free for the enterprise to which God had ealled him, hurried back to Oroomiah, to prepare for the undertaking.

But, ere we set out on the journey, let us take a view of the field before him. At what time the Nestorians entered the Mountains of Kûrdistan it seems now impossible to determine. The merciless Tamerlane, in the middle of the fourteenth century, doubtless drove multitudes for shelter to these fastnesses. But other fiets would indicate that a part of them had previously settled there. Indeed, how would they have dared to flee thither, had not some of their own people been there to receive them? Kûrdish fanaticism in that age could have been scarcely more tolerable than that of Timoor himself.

The Kûrds appear to have been there from a very early period. Xenophon and his Greeks, B. c. 400, had reason 
to remember them. Some say that the Kir mentioned in 2 Kings $16: 9$, Isa. 22:6, and Amos 1:5, refers to the Kîrds, and that they are identical with the Parthians, who slew Crassus and twenty thousand of his soldiers, 53 в. c. But, though these positions are doubtful, yet it is well known that the celebrated Saladin was a Kûrd, and others besides him have risen to distinction. Dwelling in secluded valleys, separated from nne another by rugged mountains, whose snowy summits pour down streams on every side to refresh the vegetation below, their character partakes at once of the force and exclusiveness peculiar to mountaineers. Divided into numerous tribes, whose interests often interfere, they are ferocious, rather than brave. Accustomed to stratagem and surprise, they are noted for suspicion and treachery, and quite as celebrated for their robberies as for either. In the language of Mr. Dwight; "They have the character of sly rogues, full of hospitality and full of deceit. This witness is true." Mr. Rich, who gives a very good character to the tribes further south, says, "Those of Khoshnav and Rowandiz are, to the last degree, savage and stupid; they have no sort of seruple about murder, but would not miss a prayer for the world. Years ago, two districts quarrelled about a dog, and seventy men fell on the spot, thirty of them in a mosque, where they had just united in prayer ; and the quarrel is kept up to this day." *

But the Hakkary tribe is perhaps one of the most faithless and ferocious among them. Mr. Rich's tatar, who travelled from Bagdad to Van, through Amadia and Julamerk, said, "They were wilder than any Kûrds or Arabs he had ever seen." In this goodly class, however, he seems to have included the Mountain Nestorians as well as the Kirds. The same causes that have closed the Hakkary country to travellers from without have given full scope to the development of Kûrdish character within. 
But, as their character will sufficiently appear in what follow: a word on the political condition of Kûrdistan previous to the visits of Dr. Grant may here suffice. Nominally subject now to Turkey and now to Persia, but never really to either, it enjoyed a wild liberty of its own, listening to the overtures of both sides, as seemed most favorable at the moment for phunder or immunity. The tribes rere governed by hereditary chiefs; though the inheritance was not always allowed to pass quietly in the natural course. The predecessor of the emir was the father of his nephew, Suleiman Bey, to whom, of course, the government rightfully belonged. Superior abilities, however, prevailed over hereditary right; and to the lawful heir was assigned an inferior post, his rival keeping a strict look-out for any thing like an effort to recorer his own. He had not dared to kill him, for the son of their old emir had many powerful adherents in the clan, and, according to Kurdish law, the murder of Suleiman Bey would have been the signal for his own, and the commencement of a blood-feud in the tribes, whose end none could foresee ; for their lex talionis requires the descendants of the murdered, however remote, to retaliate on the relations of the nurderer, till the equilibrium is restored to the satisfaction of all concerned.

The hostility between the Nestorians and the Hakkary Kûrds seems to date back as far as the establishment of Christianity and Mohammedanism side by side in the mountains. This had been aggravated recently by the present Patriarch grasping after a degree of power said to have been unknown to his predecessors; and, as he possessed no little diplomatic tact and energy, the jealousy of the Kiuds towards the Nestorians was full as great as it ever had been. The late emir had been his personal friend, and that friendship was now transferred to his son. This, of course, did not promote any kind feelings between him and the usurper. Suleiman Bey naturally sided with Mar 
Shimon; and this, again, increased the jealousy of the emir against both.

This unhappy state of things occasioned the burning of the Patriarch's house, at Kochannes, before ever Dr. Grant entered the mountains, and continued afterwards to produce results yet more disastrous; for the emir, with all this difficulty at home, sought to strengthen himself by alliance abroad, - at one time with Turkey, at another with Persia, but most of all with Barlir Khan Bey, chief of Bûhtan, generally known under the title of the Bey, as Suleiman Bey was by that of the MIûdebbir.

Neanwhile, the Turks, who included Kûrdistan within the limits of their empire, were annoyed by the existence of Nestorians and Kûrds, equally independent, within its boundaries, and they were determined to subdue them.

Mohammed Pasha, of Mosul, having subdued his own rebellious district, and also the Kûrds of Bahdinan and Berwer, now looked with longing eyes across the boundary of independent Kûrdistan, and sought to add that also to his extensive pashalic.

Badir Khan Bey, a friend of the emir, was a chief in the prime of life, of commanding influence among the tribes, and full of ambitious schemes, aiming at nothing less than entire independence of the Sultan, the subjugation of the Mountain Nestorians, and the union of all Kûrdistan under his single sway.

Such was the troubled sea, vexed by opposing storms, on which Dr. Grant was about to launch, in the name of Christ and. his kingdom. 


\section{CHAPTER VII.}

EOURNEY TO MESOPOTAMIA ANU ASSYRIA - SALMAS DISAPPOINIMENT CONSTANTINOPLE - ERZRÛM - DIARBEKR AND ANARCHY - MARDIN SICKNESS - NOBS, AND NARROW ESCAPE - MOSUL LIETTERS - YEZIDEES - var matTAI - AKRA - GEOGRAPHICAL DISCOVERIES.

Dr. Graxt left Oroomiah' April 1, 1839, proposing to join Mr. Homes at Erzrum; but, on reaching Salmas, he learned that the mission at Constantimople had prevented his coming, supposing the death of Mrs. Grant would break up the enterprise. Looking on this as one of many indications of Providence in favor of entering from Persia, he wrote to Oroomiah, urging the unsettled state of Mesopotamia in favor of that course, - an argument that must have been often in his nind on that sick bed, at Mardin, and afterwards. He sent, also, a letter from Yahya Khan, assuring them he would do everything to insure the success he did not doubt would crown the attempt. But the majority did not favor the plan; and Dr. Grant pressed on to Constantinople, though an umusually late fall of snow made the journey not a little perilous. For more than two hundred miles it was from two to four feet deep. On the plain, near Ararat, he encomntered a terrible storm, and almost perished in the mountains beyond. There for twenty miles he did not find a single human habitation. He himself had to take the place of his guide, who was blinded by the snow, and, where the path was not swept bare, trust to the recollections of his journey four years before. In descending the mountain, he could only determine when he was out of the path by the depth to which he sank in the snow. 
Near the sources of the Euphrates two of the party became blind from the glare of the snow; and they found shelter in a stable, at Moollah Suleiman, — such as Xenophon described, two thousand years before, - built mostly underground, and, at a distance, resembling flattened charcoal-pits. The next stage led over the pass of Dahar, where Messrs. Smith and Dwight suffered so much, and himself, also, on his previous passage. Three men had perished there shortly before his arrival. But rain har set in, and he must eross before the snow became soft; for then horses would sink to their bodies at every step. He did so; but, on the mountain, the ratin changed to snow; the wind soon blew a gale, and the snow was so deep the horses could not advance. To erown all, the guide lost the path, and declared it impossible to go on. Turning back was equally out of the question, as their tracks were obliterated by the wind, that would then be in their faces. In such a situation, benumbed and weak as he was, the courage of Dr. Grant did not fail. He could not tell how they would be delivered, but he had a sweet assurance that deliverance would come; and, like Paul in the ship, he encouraged his companions to new effort. God did not put to shame the confidence of his servant; for, just then, as unlooked-for as angels from heaven, four mountaineers came tramping over the snow before them; and, one of them consenting to turn back, they passed in safety on foot, - the men breaking down the drifts for the horses that followed after, and exploring the path by thrusting their long staves deep into the snow.

The next day, fording some tributaries of the Aras must have recalled his Braintrim experience, as his horse was carried away in one of them, and with difficulty regained the shore. He reached Erzrûm April 17, and rested a day with his kind friend Dr. Riach, then in that place. It was well for him that he hastened as he did, since the road continned impassable for weeks. His health improved amid all these hardships. He vomited but little west of Salmas, and was troubled with fever 
only for tro or thrce days after learing that place. On th 13th he left Erzrum for Constantinople, without any attendant except the surijce (hostler) from the post-house. Next day he found the bridge over the rest branch of the Euphrates had fallen in the night, and he got across only after the villagers of Ashkala had wrought for an hour in the cold water, up to the waist. He rode twenty hours that day, and his horse fell with hin twice, the day after, in the snow and mud. Arriving at Trubizond the $202 d$, he sailed, three days after, in the steamer, for Constantinople. Here new difficulties awaited him. Owing to the persecution then raging, and the absence of Mis Dwight in America, Mr. Homes could not then be spared; and, as it was altogether uncertain when he could leave, Dr. Grant proprosed to go on alone to Diarbekr, and wait there a reasonable time and then, if $\mathrm{Mr}$. Homes did not appear, to do what he could without him. To this they all agreed; and he returned immediately to Erzrûm. Here he waited nine days for his frman from Constantinople, spending the time pleasantly and profitably with Dr. Riach, Col. Sheil and consul Brant. The last two, having travelled extensively in Kurdistan, gave him much valuable information; and he had frec access to their libraries, which were well supplied with whaterer related to the history of that region. While here he wrote to Mr. Merrick, Maty 18 :

"I expect to leare here on the 20 th, or soon after, for Diarbekr; but whether my health will allow me to stay there long, or whether political disturbances may affect my movements, I know not. From this distance the horizon looks dark and lowering. Hafiz Pasha is recruiting his army, and it is said the Pasha of Bagdad has been ordered to join him.

"I trust you are now quietly seated down in - shall I say my own quiet home? $O$, no! Once and again have I had a peaceful, happy home, with all that could render it delightful. Hare I, then, a home no more? Yes; where the dearest object: 


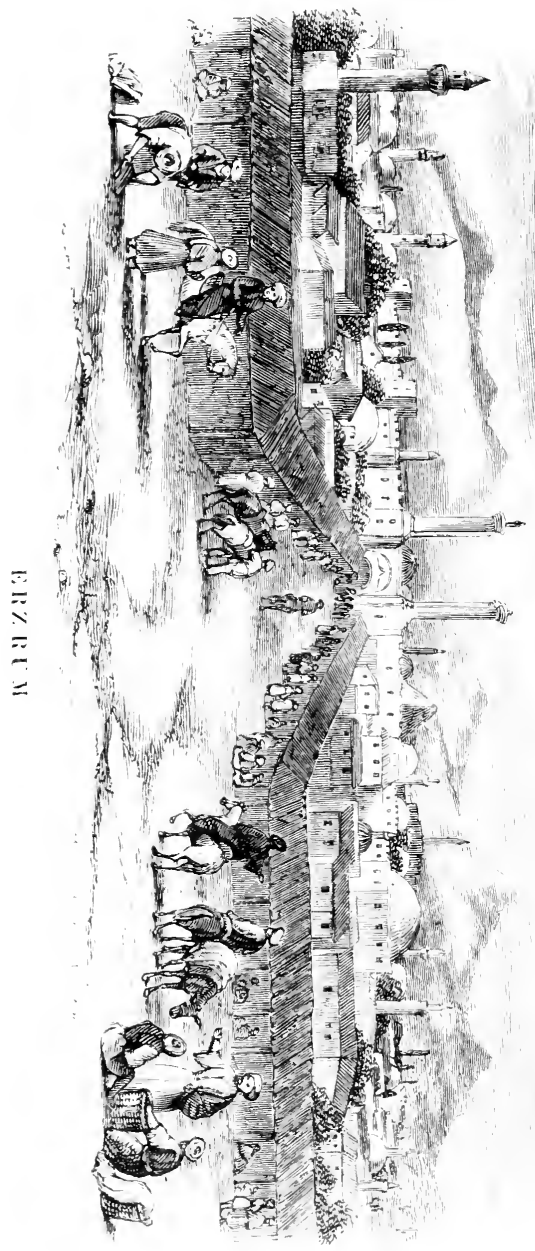



of my affections are, there is my home. With Him who is the theme of their joyful anthems, with Him who said I go to preprare a place for you in my Father's house, - there is my home. What mater, then, if for a time I wander a lonely pilgrim in a strange land, when, at best, I must be absent from my home while in this rale of tears? Let me lay up treasures in my home on high. Let me but find some precious gem to grace my Sovereign's crown, and gladly will I toil on amid trials to the end."

On the way to Diarbekr he crossed some of the mountaintorrents on solid bridges of snow, and was ferried over the Euphrates, at Paloo, on a raft supported by inflated goat-skins. Arriving at Diarbekr on the 30 th, nine days from Erarum, he found the city awaiting in suspense news from the battle of Nizib. The defeat of the Turks was soon manifest in the arrival of hundreds of fugitives, completely stripped by the Kurds. From that moment anarchy reigned. Robbery and murder were the order of the day. None dared leave the city without a guard, and even in the streets the arm of the strongest was the only law. Though the pasha hung up five heads, and four times as many ears, of malefactors, in the bazaars, yet, two days after, these very bazalars witnessed the most daring robberies. The people ascribed their defeat to Frank innovations in military tacties; and when Mr. Homes arrived, on July 3 , he and Dr. Grant not only heard themselves cursed in the streets, but the people openly declared their purpose of killing every European in the place.

Finding Diarbekr becoming so unsafe, both from anarchy and the unhealthy climate, - the thermometer being already $98^{\circ}$ in the shade, - they left for Mardin on the 10th of July, with an escort of thirty horsemen, part sent by the pasha, and part returning to that place. They had intended to prosecute inquiries among the Syrian Christians of that vicinity; but not even here did they find rest for the soles of their feet. Their lives were openly threatened only a few days after their arrival, 
so that the governor offered them a guard. This they declined, not thinking it best to manifest any alarm; and soon all excitement died away, and they visited the pasha and others of the nobility in quiet.

And now fresh trouble came, in the form of a severe attack of infammation of the bowels. This cauced much suffering, and for a while held him suspended over the grave. In the near prospect of death, next to his concern for his absent children, his greatest grief was that he had come so far to do so little, insteal of entering the mountains at once, from Persia. The prospect before him was far from encouraging. There were no Nestorians remaining in Mosul, - all had gone orer to the Pope; and it was doubtful, if he went there, whether he could remain in safety, or proceed either east or south. Bagdad was in commotion; so was Sulimanieh; and Turkish authority was very weak in the whole region. At one time it seemed as if Providence, hedging up their way in every other direction, would lead them to Aleppo, to wait for a more favorable time; and, ever ready to follow the leadings of Providence, however they opposed his own plans, he coneluded to go there, "unless other indications should arise." Carefully to observe the intimations of the divine will, and implicitly to follow them, were principles that governed the whole conduct of Dr. Grant. His child-like reliance on Providence is beautifully illustrated by an incident that occurred during this journey. "Suppose that, when you reach —_, said a friend, " you find you cannot stay there, what will you do?" — "I will go to ___. " And suppose that then your way is hedged up?" I will do so and so, was the reply. At length, thinking he had certainly brought him to a stand, his friend asked, "And what then?"- "I do not now know," said Dr. Grant; "but, when God brings me there, he will point out the way in time enough for me to walk in it." This spirit of reliance on God furnishes a key to much in his subsequent course that were otherwise inexplieable; for, 
being assured that the mountains formed a part of "all the world" into which the diseiples were to go and preach the gospel, and that the existing exigences of the mission rendered it exceedingly desirable that it should be done immediately, he took it for granted that God would take care of the man who should endeavor to do it, and afford him all necessary guidance, just so fast and so far as it was required. He did not need to wait long, on the present occasion. That God who had proved the faith of his servant so often, subjects it to only one trial more before he gives him the desire of his heart.

On the 6th of September, while Dr. Grant was riding out with Mr. Homes, the mob killed the governor, in his palace, in open day; and, after putting several leading men to death, sought the lodging of the missionaries, with their bloody weapons. But God had led them out; and, when they returned, made the gates to shut out those whom man thus meant to shut in for slaughter.

They retired to Deir Zafran, the convent of the Jacobite Patriarch, about four miles distant, where they were kindly sheltered till the storm subsided. Some of the ringleaders, finding they were not in the city, pursued them to the village they had been visiting, and would have followed them to the convent, had not a division among themselves compelled them to turn back from their bloody errand.

Dr. Grant and Mr. Homes had now spent two months in Mardin. They had found that no Nestorians remained west of the Kûrdish mountains ; and, finding so little hope of usefulness, with so much peril, Mr. Homes, in accordance with the advice of brethren at Constantinople and Smyrna, resolved to return. Dr. Grant, with a full view of the trials before him in his solitary journey, could not withhold his consent. In review ing those days of trial, he says: "They had been days of mingled anxiety and pleasure, not to be forgotten while memory' remains. I had just risen from a sick bed, on which the tide of life seemed fast ebbing to a close, when the insurrection 
occurred; and the divine interposition of that day tended not a little to strengthen my faith, and arm me for whatever perils might still await me.

"Within the ruined walls of an ancient church, which stands in a lonely ravine, overlooked by the town, I exchanged the parting embrace with my brother and companion in tribulation. On account of the anarchy around us, we had travelled together barely two days; hut, on a bed of sickness and surrounded by men of blood, I had learned to prize the company of a Christian friend, and it was not withont a struggle each tore himself away from the other. But while Providence called him back to Constantinople, to me it seemed to cry "Onward to the mountains!"

Dr. Grant may be deemed an enthusiast. But, with less interest for the salvation of men, he had turned back from the snows of Armenia, or fled before the surges of anarchy as they broke orer Mount Masius, or grown timid in the languor of disease, or shrunk from the possible repetition of his recent perils when friendless and alone. But he looked at the deliverance rather than at the danger. In his own words, "That divine interposition armed him for future perils." The great object before him justified his pressing forward f for well he knew that, while none dared advise him to proced, lest he should fall, yet every friend of the mission was most anxious that he should enter the mountains. Moreover, it was just as dangerous to go backward as forward; and he resolved to go to Mosul, intending, in case he could not enter from thence, to return by a more southern route to Persia.

Disguised in an oriental dress, he returned to Mardin, to prepare for the journey; and so changed was his appearance that he remained two days unrecognized and undisturbed. While there, the cannon of the citadel proclaimed the subjection of the town to the strong arm of the Pasha of Mosul. This rendered his journey thither safe, and, as though providence would further approve of his purpose, he was favored with 
the agreeable society of Captain Conolly, who, tbrough many dangers, had come thus far on his way to India with despatches. It was his sad fate, on the banks of the Oxus, that afterwards occasioned the journey of the eccentrie Dr. Wolff to Bokhara.

These two men were kindred spirits, and must have enjoyed the society of each other in their journey through the home of the ancient patriarchs. They encountered some Kunds, who had intended to rob them, but slunk away from the fearless travellers, backed by a few Arabs from their last night's encampment. Dr. Grant says of this part of his journey, "The sketches of Sarah, Rebeeca and Rachel, as portrayed by Moses, were reproduced in the shepherdess watering her father's flocks at the wells, or at the close of day carrying her pitcher to the distant fountains. We seemed to be carried back four thousand years, to commune with Abraham, living in just such tents, and moving from place to place like the present Arabs of Mesopotamia." A journey of nearly two hundred miles brought them in safety to Mosul, on the 20th of Sept., 1839.

This is a walled city, with cight gates, situated on an eminence on the western bank of the Tigris. As this was one of the rivers that watered Paradise, it deserves a passing notice. It has two sources, in southern Anti Taurus. One about twenty miles west of Arghana Maaden, and ten south of Goljik lake; the other in Ali Dagh (Nount Niphates), near Paloo, where Dr. Grant crossed the Euphrates, and twenty-five miles north of Myafarekin. About two hundred and serenty-five miles from its western source it receives the Bitlis Soo (second Nicephorius of Xenophon), one hundred miles in length, and some fifty yards wide, just above its mouth. The Tigris there is three times as wide, and more than twice as deep. Soon after this, it receives the Buhtan Chai (Centrites of Xenophon), and flows on without further addition, till the united waters of the Hazil and Habor empty into it below Jezira. This is the last it receives north of Mosul, where, at the bridge, the narrowest part, it is three hun- 
dred and five feet broad, and jusu below it fifty feet deep. Other places are wider and shallower. The average breadth between Mosul and Bagdad is two hundred yards. The whole length of the river, to its junction with the Euphrates, is one thousand one hundred and forty-six miles. Its mean velocity at Bagdad is 7.32 feet per second, while that of the Euphrates at Hit is only 4.46, and the Nile, at Cairo, 1.11. The Tigris varies greatly in size at different seasons. It is lowest in October and the beginning of November, after the long drought of summer. After the middle of November it rises a little, then decreases and swells irregularly, till its tributaries are frozen up in the mountains of Kûrdistam. The great rise begins about the middle of March, and increases with the melting of the distant nnows, till it attains its height, between the middle and the end of May; and then again decreases gradually till October. It is navigated, as in the days of Herodotus, with rafts supported by inflated goat-skins. Small ones, about eighteen feet by sixteen, and supported by some thirty-two skins, come down from Diarbekr to Mosul, a distance of two hundred and ninety-six miles. From Mosul to Bagdad larger ones are used, sometimes supported by as many as three hundred skins. This royage occupies three or four days in high water, and sometimes as many as fifteen, when it is low. The rafts are taken to pieces at Bagdad, the timber sold, and the skins carried back again, to be used in the construction of new rafts.*

Dr. Grant found all quiet in Mosul, under the efficient rule of Mohammed Pasha. Little did he think that the house in which he then lodged was but a few feet distant from his grave. But so it proved; for it was next door to the church of Mar Tooma, where his body now lies awaiting the morn of the resurrection. While here he wrote a letter to Mr. and Mrs. Perkins,

* See Col. Chesney's Euphrates and Tigris, where, vol. I. 39, he gives 7.33 feet per second as the highest, and again, page 62 , as the mest velocity of the current of the Tigris. 
sympathizing with them in the loss of their favorite Justin. "You and I," says he, "are called to drink often of the eup of affliction. Would that I could have been with you ; but, though you had no earthly physician, there was one present to whom he was dearer than even to you. Well may you say, with Davirl, 'I shall go to him, but he shall not return to me.' Yes, soon shall we meet the loved ones who sleep in Jesus, never, nerer more to part. If our home is above, let us rejoice that a part of our little fimily has gone to our 'Father's house' before us. But, though we would not murmur, yet agony sometimes so overwhelms, for the moment, that we feel as if it must not be so. But God is your comforter, and to Him I commend you.

"Since I left you, I have more than once feared I should never rejoin your peaceful circle, and even now the prospect looks uncertain. But I love to think the Lord is your keeper, and in Him only would I trust; to Him alone would I look for guidance, neither shrinking from trial or rushing into danger uncalled. To preserve his life for his great work is the most solemn duty of the missionary. But $I$ also believe that a readiness to face danger, and even death, is implied in the command to take up the cross, and fear not them who can kill the body. Paul counted not his life dear unto himself. Christ sent forth his disciples as sheep among wolves, and told them that the time would come when whosoever killed them would think he did God service; as the Moslems at Mardin, when they har killed a Christian in his bed, a few days before we fled, boasterl that it was a work of merit, for which God would reward them. Perhaps by our perils there, God would teach us that he who seeketh to save his life shall lose it; for it was to avoid what were deemed greater perils that that ronte was recommended. I hope to leave for Amadia in a few days, and what course I shall pursue then will depend on the indications of Providence at the time."

The day before he left Mosul he wrote to Mr. Merrick. 
After describing his perplexities in view of the difficulties before him, and the advice of some to abandon the enterprise, he proceeds :

"Why, then, am I still prosecuting further plans and labors in this region, while my path camnot be free from danger, and so many of my brethren have adrised me to leave the field? I look upon the objects I hope, by the blessing of God, to accomplish, as of very great importance, not only to all missionary labors in these parts, but to our own mission, to the whole body of the Nestorians, and also to my own fairest hopes of future usefulness. I cannot leave the field till I have reasons which I can plead at the judgment-seat, where I expect soon to stand. "Whether I shall penetrate further in to the mountains I cannot decide now, but shall be guided by future indications. I feel reluctant to enter upon so important an undertaking entirely unsupported by the Board or my missionary brethren, and I am aware that many will aceuse me of madness for doing $i t$. But it is a small thing to be judged of man's judgment. Hy motives, my feelings, my desires, my hopes, are all open to the eye of God. To Him I commit my case, myself, my all. By His judgment I stand or fall. If I am suecessful, to Him be all the glory. If I fail, I fail in a good cause, and, through the grace which is in Christ Jesus our Lord, it may be set to my account that it was in my heart to sueceed, that God might be glorified. In myself I am weak, - I am nothing; but I feed strong in the Lord, in whom is everlasting strength; not a hair of my head will be tonched without his permission. So long as he requires my poor services here, he will take care of me. For him would I live, and for him would I die. Then I can say, for we to live is Christ, and to die is gain."

On the morning of Oct. 7 Dr. Grant left Mosul for the mexflored regions of Kurdistan, accompanied by two Nestorians from lersia, a Kurdish muletecr and a lacass (police-officer), from the Pasha. Leaving the gate, he passed at once on to the 



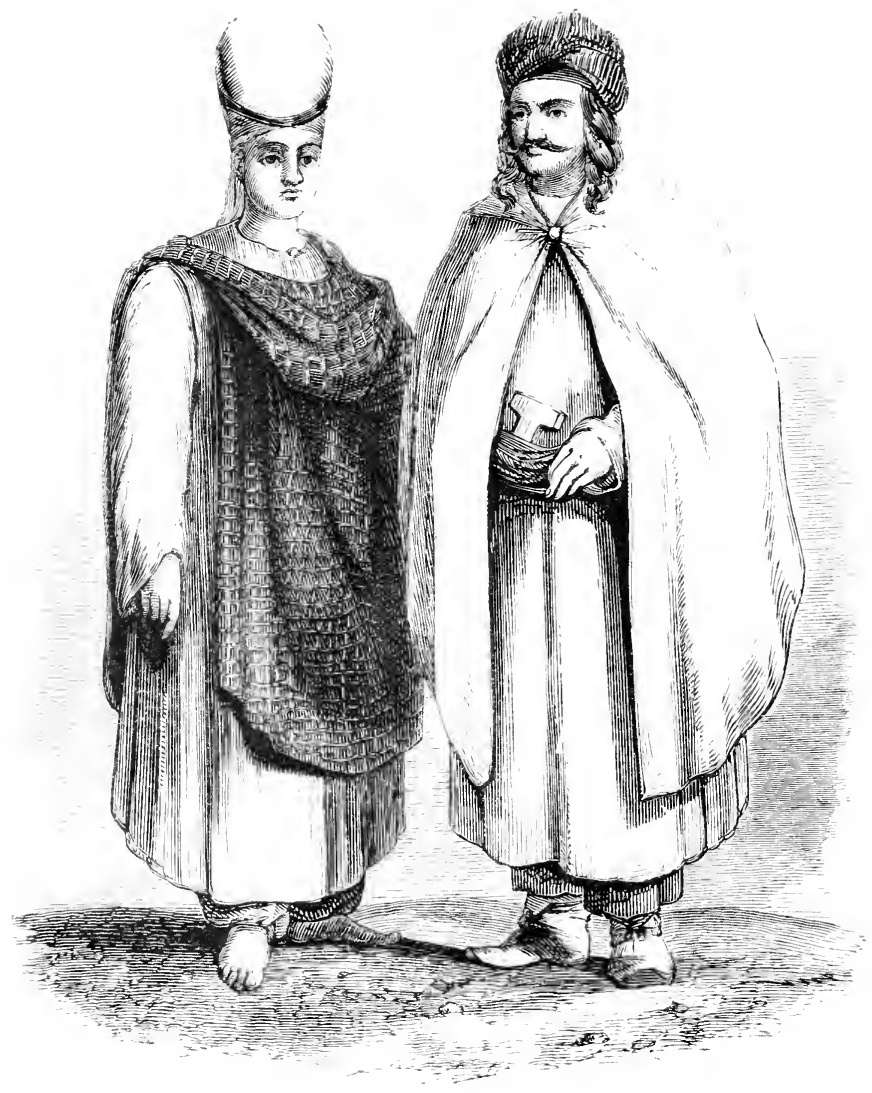

IHUIDELS 
bridge of twenty-one boats that here spans the Tigris, crowted with men and animals in picturesque confusion. This passed, he stood anid the rums of Nineveh, now waste and desolate. Black Arab tents occupied the place of her palaces, and some of their women were weaving sackcloth, as if for the mourning attire of her " whose merchants were multiplied above the stars of heaven." On one of the ancient mounds stands the modern village of Nebby Yunas (the Prophet Jonah), and under the mosque they pretend to show his tomb.

Four hours' ride brings him to Baasheka, a large village of the Yezidees. Extensive olive-groves impart a cheerful aspect to the scene, and several tombs of their Sheikhs attract his attention as he approaches. These are cubical structures, surmounted by fluted cones, that rise to the height of about twenty feet. They are built of stone and lime, plastered on the outside, and present a neat appearance among the rough, flat-roofed houses of the village. His welcome into one of the latter was not the most cordial ; but the cavass at once understood the trouble, and removed it. Dr. Grant had been mistaken for a Moslem, and as soon as the host was enlightened on that matter he welcomed him with alacrity; for Yezidees like Christians much better than they do their Mohammedan neighbors.

They believe in one God, and teach that Satan substituted a Jew for our Saviour on the cross, so that Christ ascended into heaven without having died, and will appear again from thence to subrue all men to himself. They baptize both by immersion and sprinkling, use the sign of the cross, and, putting off their shoes, kiss the threshold of a Christian church before they enter, but never visit a mosque. Moreover, they practise eircumcision; hut, along with all this, they have also a leaven of Sabianism. They adore the rising sun, and kiss the object first touched by his early rays. They will not blow out a eandle, or spit in the fire, lest they defile that sacred element. They will not speak disrespectfully of Satan, alleging that, though now 
fallen, he will one day be restored to lavor, wnen it might be inconvenient to be found among his enemies. Instead of pronouncing his name, they call him Lord of the Evening, or Sheikh Maazcm (exalted chief); nor will they tolerate the mention of the word Shat, the usual name of the Tigris, because of its resemblance to Sheitan (Satan); even the word naal (a horse-shoe) is also proscribed, because it is only a transposition of laan (to curse), as though Satan were either accursed or cursing. It is said they used to make offerings to him by throwing money and jewels into a deep pit in the mountains of Sinjar, which the Turks plundered of the offerings of centuries when that district was conquered. Here the Yezidees call themselves Daseni, from the ancient name of the province, Dasen. It was a Nestorian bishopric in early times. Their great temple at Sheikh Adi, where they come together to their annual festivals, is said to have been once a Christian convent. Mr. Rich calls them brave, hospitable and good-humored, and says that under the British government much might be made of them. Dr. Grant asks, "Can nothing be made of them under the gospel ?" and adds, "That will be a joyful day when prayer and praise to God shall ascend from hearts now devoted to the prince of darkness."

Two hours' ride to the north-east brought him in sight of the ruined convent of Mar Mattai (St. Matthew), founded 334 A. D., in the days of Sapor, and containing the tomb of the celebrated Abulfaraj, whom eren Gibbon styles " eminent, both in his life and death. In his life, as an elegant writer of both Syriac ant Arabie, a poet, physician and historian, a subtle philosopher and a moderate divine; in his death, as his funeral was attended by his rival, the Nestorian Jatriarch, with a train of Greeks and Armenians, who forgot their disputes, and mingled their tear: over the grave of an enemy." It stands high up on the southwestern acclivity of Jebel Maklúb. For some time before reaching the foot of the mountain, one wonders how he is to 
climb the rock before him. It rises with so steep and uniform a slope as seems, at least, to forbid all approach on horseback The hollows in the side of the mountain look as if a huge knife had been inserted at the top and drawn downwards, the incision deepening and spreading as it went. The convent is perched upon a narrow ridge, between two of these, about half way up, and at a distance seems inaccessible; but, once under it, all is explained, - a zig-zag path, partly cut in the rock, partly built aginst the sloping sides, leads up to the very door. The steepness of the ascent may appear from the fact that lumps of stone and mortar, from the ruined walls, have rolled to the bottom of the hill, though a horse descending rapidly needs some twenty minutes to follow down the road. The buildings are large and irregular, comprising two churches and several edifices, with courts, besides many cells cut in the living rock. When Dr. Grant was there they were deserted, owing to the ravages of the Ravendooz Kûrds, who plundered the convent and killed several of the monks, seven years before. They have since been repaired, and occupied by a bishop and monks; but how changed from the populous structure of former days, that justified the boastful inscription on its walls of "Dairo Alephoyo"! (monastery of thousands).

In the hollow beyond the convent is a cave at the very apex of the valley. A semicircular wall of rock, rising high above it and sweeping far round on either side, leaves hardly room for the path that leads up to it; but, once there, you are abundantly rewarded for all your toil. Behind you is an inner chamber, in which the water falls, drop by drop, into a crystalline pool below, and passes noiselessly into a basin at your side, so clear that the rays of the sun do not reveal a single mote in its pellucid depths. Lying there in the cool shade of the rock, and looking out under the large trees directly before the cave, your eye overlooks the lower ridge, between you and Baasheka, and ranges over the rast plain of Assyria, across the Tigris, and far 
into Mesopotamia. You gaze on a scene at once classical and sacred. There Nimrod, Sardanapalus, and Sennacherib, lived and reigned. Xenophon and his ten thousand men once crossed that plain; and so did Alexander. Romans and Saracens in turn have marched their armies there. Over the Tigris, at Mosul, Tamerlane built a bridge, across which his hordes passed continuously for seven days. And yet this place, so lovely in itself, and so suggestive of great thoughts, is the summer resort of the Jacobites of Mosul, to drink and carouse. Their bottles of arrack lie in the erystal pool, and these rocky walls reëcho their bacchanalian revelry.

While Dr. Grant visited these places his attendants had gone on, and he overtook them, just at dusk, in the Yezidee village of Mohammed Ravshan. Here his acconmodations were so wretched that, to avoid the vermin in the houses, he spread his carpet out of doors; and, after a social chat over some yogboort (sour milk) and herbs boiled together, - all that the village could afford, - he lay down to sleep in the open air. Fortunately a shower of rain disturbed him in time to recover his horse just as robbers were leading him away.

Next morning he mounted at dawn, and enterer a broad, level plain, watered by the Hazir and its tributaries. This is the Bumadus, on whose banks was fought the famous battle between Alexander and Darius. *

He found the Nestorians reduced to a few villages in the northern part of this district, and the fertile plain desolated by war four times within six years, - twice by the Kurds, and then by the Turkish Pashas of Mosul and Bagdad, - till the miserable inhabitants had scarce a morsel to eat or a house to shelter

* The names of the Hazir and Gomel are accidentally transposed on Dr. Grant's former map; and the name of Beth Garmæ (house of bones), which he applies to this region, belongs to a district further south, about Kerkûk Kifri and Suleimanieh, below the lower Zab. Assemani (Iv. 747) says it is south of Adiabene and Erbil, aud north of Sittacene and Apolloniatis. 
them. Instead of furnishing Dr. Grant with food, they begged it from him, as, four years after, they did from the writer of these pages.

In the afternoon, as he approached Akra, the scene was changed. For a mile the road was shaded by a continuous canopy of foliage. The golden pomegranate blended with the rich green of the olive; the luscious fig alternated with the peach and the apricot. The plum and cherry tree, too, were there; and, under all, the modest blackberry held out its fruit within his reach on the saddle. It was the first time he had seen it sinee leaving home, and he welcomed it as a friend of his early days. The luxuriant fertility of the plain is in striking contrast with the bare erags of the mountains, that rise abruptly behind the town. A castle, perched on the nearest cliff, had just been demolished by the Turks, and its chief carried prisoner to Bagdad. Another of the same family had been set over the province of Amadia; and it was to secure his protection through the district that Dr. Grant had taken this route, - longer, by two days, than that through Elkosh.

He welcomed the lonely missionary with Persian politeness, rose from his carpet as he entered his tent among the gardens, and seated him at his side, saying he regarded his visit as a favor from God. This was all explained, as, hardly waiting for a reply, he held out his hand for the doctor to feel his pulse. After prescribing for him, they conversed freely in both Turkish and Persian, his guest adroitly turning the conversation to the charms of the surrounding scenery whenever it verged toward local politics, - a topic he did not care to meddle with. A son of the chief, about eight years old, ran in with a pomegranate he had piereed with a rifle-ball, and received a present for such proficiency in Kûrdish education. This consists mostly in learning to handle weapons skilfully, and ride fearlessly over the roughest of their mountain-roads. Some knowledge of letters is acquired, indeed, by men of rank, and there are even 
females who can read the Koran; yet, with all this want of education, Dr. Grant found the Kûrds manifest a desire for information truly encouraging. Before he left the tent the chief gave the kavass a receipt for his safe delivery, as though he had been a bale of goods; and assigned him a guard of his own, since he was now responsible for his safety, to the Nestorian border.

Dr. Grant spent the second evening with the mutsellim (locial governor), who was verging on delirium tremens, from drinking so much brandy, to counteract, as he said, the bad water of the place. Like Saul, he had summoned a skilful musician to expel the evil spirit by the soothing strains of a harp, that had originally seventy-two strings; and, though eight of them were broken, the music was still quite harmonious. 'The doctor, along with other remedies, prescribed total abstinence, and we shall hear from his patient again.

Akra boasted of a Nestorian school in its earlier days; but now only twenty villages of that sect remained in the district. Those in the town - some thirty houses - had become Papists; and they and the Jacobites each had a church excarated in the solid rock of the mountain. The whole population might amount to two thousand souls.

Dr. Grant, having sold his horse, set off at sumrise, Oct. 10, on a mule. At first his road lay along the base of the mountains to the west; then, entering a pass to the north, he eame to the Hazir. He had now left the route of former travellers, and fairly entered on an unexplored region. The first day he passed three or four Nestorian villages, one of which contained nearly a thousand souls, and at night lodged in a Kûrdish hamlet, at deadly strife with another just in sight. Three men had been killed from that, and only two from this; and now the former were watching to settle the quarrel by the deliberate nurder of another of their neighbors. On the third day from Akra he entered Amadia, - the first European that had stood within its 
wals. This town is situated on the top of a rocky truncated cone, about a thousand feet high, separated from the Matineh range by a narrow dell, and overlooks the large and irregular valley of the Sapna, which lies between that range and the Gara on the south. The wheat of the valley is good and abundant, and the grapes the finest Dr. Grant had seen. The raisins made here are celebrated even in Persia. But the climate is very unhealthy, and war had made sad havoc among the people. Dr. Grant climbed up a long and weary foot-path, and passed the Turkish sentinels at the gate, at two P. m., Oct. 12. The chief lue had visited at Akra was not allowed to enter this fortified post; and, with his castle there in ruins, and a strong garrison here, the province was deemed secure against revolt. Out of a thousand houses in the town, three-quarters were now in ruins, and the sickly looks of the remaining inhabitants heightened the general aspect of desolation. Both the civil and military governor were sick, so that the visit of a physician was to them most welcome. Dr. Grant spent a quiet Sabbath here; and, so completely did their language and general appearance resemble their own, that his Nestorian attendants rebuked some of the Jews (there were about a hundred families there) for working on the Lord's day. He found that more than half the Nestorians of the province had fallen away to the Pope, though the adherents of Mar Shimon were much more numerous in Berwer, the next district to the north.

Dr. Grant ascertained that the Iabor, or Khabor, rises near Julamerk, and flows within ten hours of this place, to the west, and is not the same with the Bitlis Soo, as MeDonald Kinneir had asserted; while the Kab, visible from the walls some ten miles to the east, was identical with the Hakkary river of the maps. And though a certain English writer, who ought to have known better, * says that the Ravandooz tributary had bee a mistaken for the Great Zab up to the visit of Mr. Ains.

* Chesney's Euphrates and Tigris, vol. I. p. 24. 
worth in 1841, * yet Dr. Grant, in 1839 , discovered that it was only a branch, and that the so-called Haksary river was the real Zab, and published his discovery, both in England and America, before Mr. Ainsworth. That the author of the Euphrates Expedition was not ignorant of Dr. Grant's book, appears from his reference to it on the 113 th page of the same volume; so that such a statement is the more difficult to explain.

On Monday, besides attending to the sick of the town, $\mathrm{Dr}$. Grant prescribed for more than forty of the garrison, and received the warmest thanks of the governor, who said God had sent him to them, when they had neither medicine nor physician, to alleviate their sufferings.

Kasha Mendo, the Nestorian priest, bewailed the low state of his church, and feared that his people, in their ignorance, would fall before the wiles and violence of the Papists. His own father had been bastinadoed into papacy. "But, with God and truth on our side," says Dr. Grant, "we have nothing to fear, if we only do our duty." The Nestorians have nobly stood their ground, and are still on the watch-tower. As I approached their rocky fastnesses, their first inquiry was whether I were a 'Catoleek,' declaring such wolves in sheep's clothing could never enter there."

* This mistake is still continued, even in such a work as Black's Gene ral Atlas, Edinburgh, 1851. 


\section{H A P T E R V III.}

FIRST JOURNEY IN TIIE HOUNTAINS - DUREE - VIEW FROM SUMMIT OF PASS - RECEPTION - LEZAN - SABBATH - SACRAMENT - ASHITIIA PRIEST ABRAHIM - CHUMBA - MALEK - NESTORIAN WOMEN - NAZEE MOUNTAIN-ROADS - MAR SHIMON'S RESIDENCE - JULAMERK - BA8H KALAIf, AND SICKNESS OF THE EMIR.

At an early hour on the 15th of October he was on his way to the goal so long desired, and now in view. The nearest villages of Tyary are twelve hours distant from Ashitha; but one of their bishops resides at Dîree, five hours nearer, and he engaged mules to that place. These could not be brought into the town, lest they should be pressed into the scrvice of the government; and he therefore descended on foot, with the brother of the priest, who went to introduce him to the bishop. His kavass from Akra was loth to go any nearer the dreaded Tyaree, who were regarded as almost invincible, and said to be able to vanquish their enemies by some magie in their looks. They once drove the flocks of Amadia from under its very walls; and when the celebrated chief of Ravandooz threatened to add their country to his other conquests, they hung up the heads of seven of his men over a narrow bridge, as a sample of what would befill those who dared to cross it. The chief, after one or two sinilar warnings, wisely turned away. "To the borders of their country," said the brave Pasha of Mosul to Dr. Grant, "my head for yours. Carry gold on it, and fear not; but I warn you that I can protect you not a step beyond. These infidels know neither pasha nor sultan, but from time immemorial every man has been his own master." At the summit of 
the rocky defile that led over Toora Matineh the eyes of Dr. Grant rested, for the first time, on the mountains of the Nestorians, across the intervening vale of Berwer; and, as he approached Duree, after a weary ride of seven hours over the rough passes, he was hailed by the questions, Who are you?what do you want? - where are you going? The demand was echoed from every side, and seemed to issue from the rocks ahove him. The deep Syriac gutturals of their stentorian roices would have startled a less fearless heart. Their fierceness of expression, joined to the inquiry they made of the guide whether the company were Papists, or bad men whom they might rob, bereft the poor kavass of all the courage he had left, and he was glad when Dr. Grant consented to his return.

Finding that he spoke their language, the people gathered round the missionary as though he had been one of themselves. They were bold and outspoken, without the fawning sycophancy of the Rayahs of Persia or Turkey, and in their own rough way welcomed him to their mountain-home.

Next day they came for medicine from all directions. One was alarmed by the operation of an emetic, but soon felt so relieved he wanted more; and others called loudly for the same. The bishop - a venerable old man, with a long white beard - was rery cordial, and took him into their ancient ehurch. It was a cave, high up on the mountain-side, enlarged by an addition of heavy masonry in front, and within as dark as midnight. Says Dr. Grant: "He guided my hand to a plain stone cross on the altar, supposing that if I was a Christian I should press it to my lips; and I confess there is something affecting in this simple act of theirs, disconnected as it is with image-worship, or the corrupt observances of the Papists. May it not be that their abuse of such symbols has earried us to the opposite extreme ?" The bishop slept in his lonely church, so as to attend pray r's before daylight in the morning, and was much pleased witl the gift of a box of matches to light his 
lamp. A number of bee-hives belonged to the church, and their fine clear honey was held peculiarly sacred. Red squirrels, the first he had seen in the East, were skipping about in the shady walnut-trees; and iron mines, not far off, were wrought by the Nestorians for the chief of Berwer, for Dûree is subject to the Turks, and immediately responsible to him.

The high range he had seen from the crest of Toora Matineh still separated Dr. Grant from Tyary. He had been warned at Nosul not to enter till he had an escort from Mar Shimon; but ten days' delay, at that season, was to be avoided, if possible. His generous spirit suggested that going in at once would manifest a confidence that might gain their good-will. Still he would nci venture on his own responsibility; but, as the bishop also favored the idea, he resolved to go. He exchanged his Turkish boots for the bishop's sandals, made of hair, - for he must pass places where he would slide on the smooth narrow ledges of the mountain-side, if he attempted to walk with ordinary shoes, - and, thus equipped, set off early on the 18th. A toilsome ascent of an hour and a half brought him to the summit. And here we must let him speak for himself:

"From this point the Nestorian country opened up before me like an amphitheatre of mountains, broken with dark, deep defiles and narrow glens, in a few of which I got a glimpse of smiling villages, that for ages had been the secure abodes of this branch of the church. Here was the home of thousands of Christians, around whom Omnipotence had reared ramparts whose summits blended with the sky. In this 'munition of rocks' has God preserved us, for some great jurpose, a remnant of his ancient church, safe from the beast and the false prophet, - from the flames of persecution and the clangor of war. As I gazed, I could not but exclaim:

- On the mountain-top appearing,

Lo, the sacred herald stands!

Welcon $₹$ news to Zion bearing, 
Zion, long in hostile lands :

Mourning captive,

- God himself shall loose thy bands!'

"I retired to a sefuestered nook, where I could feast my eyes with the prospect, and thank Ilim who had brought me through many perils to behold the land whence issued such bright beams of hope for the future of the East. My thoughts went back to the days when their missionaries traversed all Asia, and, for more than a thousand years, preached the gospel in Tartary, Mongolia, and China itself; to the time when, not from Nestorius, but from Bartholomew and Thaddeus, if not from Thomas himself, these lands first received the knowledge of a Saviour. I looked at them, sunk into semi-barbarism, the flame of vital piety almost quenched on their altars, and my heart bled for their condition. But Faith pointed to the time when these glens shall reëcho the glad praises of our God, and, like the morning-star, this church shall usher in a glorious day. But, ere that bright period, there is a battle to be fought and won. Let us arm this biave band for the contest! On, then, to the work!" And on he sped, down the steep descent, cautiously climbing over the clifl's, creeping carefully along the slippery ledges; now resting under a wild pear-tree, and anon riding down the zigzag path to the banks of the noisy Zab. Here Lezan, one of their large villages extended for more than a mile anid fertile gardens.

It seemed as if God had guided his servant to one of the most. inspiring prospects that even that country of natural grandeur could present, to nerve him with fresh zeal for the trials yet before him. Had he entered by Ashitha, he would have passed up a dreary glen piled with rocks, between which scarce a particle of soil was to be seen, and then his view from the summit had been bounded by the narrow valley of that village and the snowy peak beyond. Had he crossed nearei the Kab, his lower position had eut off the distant view. But an unseen 
and led him to the very spot where, of all others, his heroic spirit revelled in the grandeur of the scene. Nor was this the only smile vouchsafed to the fearless pioneer. As he drew neir" the village, he asked himself, "What reception shall I meet fiom these wild sons of the mountain, who never saw a foreigner bofore? How will they treat the stranger thrown helpless on their mercy?" One breath of suspicion might blast his fondest hope. But prayer had been offered for him, and God answered it better than he could have devised for himself. The only man he had ever seen from this remote region had come to him nearly a year before, hardly hoping that his sight could be restored. For six weeks he had groped his way from village to village, till Dr. Grant removed a cataract from his eyes in Oroomiah; and now, scarcely had he entered Lezan, when this young man came, bringing a present of honey, and intro ruced him at once to the confidence and love of the people, - an incident that unites to the poetry of fiction the solidity of truth and the sweetness of a reward of faith. He was soon engaged in dispensing medicine to others; and no wonder that then, and long after his death, the mountaineers said that this, his first journey, was like the journeys of Him who went about doing good.

He was invited to the house of the Reis (hear of the village), built, like the rest, of stone laid in mud, with a flat roof, two storics high (as they generally are, on one side at least, when built against the side of the momtain), and with two or three rooms in each. Seated on the floor of a large upper room, entirely open on one side, food was brought in a huge wooden bowl, and placed on the skin of a wild goat, that, with the hail side down, served at once for table and cloth. Coarse millet bread was laid round the edges, and each with a wooden spoon dipped from the bowl. Whenever the goat-skin was used, he noticed in it ne fragments of previous meals, left in order to retain the blessing once pronounced over them by the priest, for 
the common people cannot use the ancient Syriac, in which their prayers are written.

The women seemed neat, frugal and industrious. Their spinning illustrates Proverbs 31 : 19; for, as they use no wheel, holding the distaff in one hand, they twirl their long woorlen spindles with the other, stopping to wind the thread on them as fast as it is made. They clothe their households in a scarlet or striped stuff, like Scotch tartan in texture and material. And, as in the Highlands, so here also, a man's clan is known by the color of the strije and the pattern of the ornament with which the knitting-needle has adorned his socks. In the evening two of the women in the house sat with their husbands in the rows that lined the walls of the apartment, - a fact which none accustomed to the seclusion of the sex in the East would fail to notice. Each of them gave him a brass bracelet to show to the ladies of his own land, and wondered how they could negotiate their matrimonial engagements, or their fathers give then away without a dowry in return.

The houses in Lezan are scattered here and there orer the terraces that rise irregularly from the river, and present a beautiful appearance as they peep out of the fields and shrubbery. Grapes, figs and pomegranates, are found here, as in other rillages on the Zab. Rice is also cultivated, to the great injury of health. Apples grow in the higher villages, but not rery good. Wheat, quite a luxury among them, is brought from Amadia, in exchange for honey and butter ; for they cumnot spare the ground needed for it growth. Millet - called by them praga - is the great stuple, and is eultivated erarywhere.

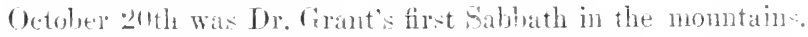
A brard struck with a mallet ammoned the village to the church at smirise. Farh one, as he entererl, put off his thoes (Ex.

* Quers. - Does not this practice explain that sentence in the Yeste rian inscription, discovered in China, which, speaking of Christians, says, "They beat the wood, sounding out the roice of benerolence and merer"? - See Williams' Midrle Kingdom, Ir. 292. 
$3: 5)$, ar 1 , after kissing the threshold, passed on, hat in hand, to kiss the gospels on the altar, and the hand of the priest. The church was solidly built of stone and lime, with an arched roof, and might stand for ages. Some, according to their books, have already stood more than fourteen centuries.

They quoted Matt. $7: 14$, to explain the low, narrow door, that recuires one to stoop almost doable before he can cuter. The prayers and chanting of the psalms were in the ancient Syriac, now an unknown tongue to all, sare a very few of the priestis. One of these translated the gospel for the day into the spoken language, and this was the preaching. Sometimes this is accompanied with legends, of which there is no lack. It was a sacramental occasion, and the elements consecrated in the "holy place" were brought out by a priest and deacon. Each, in turn, receired a morsel of bread from the priest, who held $a_{0}$ napkin under the chin while he put it into their mouths; and they then drank of the wine, which the deacon held with similar care. In the whole service there was no idolatrous adoration, not even kneeling to receive the elements; but, on the contrary, an almost seriptural simplieity.

The priest first partook himself, and then offered the elements to Dr. Grant. Up to this time he had not communed with them: but he felt that to decline now would do as much injustice to his own feelings as to theirs. For many months he had not enjoyed the privilege. God had led him safe, through many perils, to a people who had received the gospel from the apostles, and preserved its doctrines comparatively pure; and, though the want of spiritual life was sadly manifest, he hoped some sparks of piety were yet burning on these altars. Though languishing, he could not regard tb? church as altogether dead. His heart was drawn out to them in tender love, so that, to use his own words, "seldom had he commemorated the love of Christ under circumstanees more full of interest." The congregation, which had behared with nuch propriety during the service, retired quietly at its 
close, and, in passing out, each received a morsel of meat rolled up in a thin leaf of bread. This was a remnant of the Agapæ (love-feasts) of the early church. Throughout the day there was no noisy merriment, and no attention to business, but a quiet stillness pervaded the village, such as he had seldom seen in more favored lands. Formerly, they are said to have put persons to death for travelling on the Sabbath. In the evening they assembled again at the church for prayer, as they do norning and evening through the week. Yet, unlike other places in the Kast, many repeat their prayers during the week at home. Before commencing they kiss a small wooden cross, simply as an expression of faith in Christ, for they never regard it as an object of worship.

He was so thronged with the sick from all the region, that he had to forbid more than three or four coming forward at once. It was ten o'clock, in the forenoon of October 21, before he could leave to pursue his journey up the valley of the Izani. For four miles his path lay through an almost continuous village, Minyanish commencing where Lezan ends. In Zawitha, across the stream, on the southern side of the valley, they boasted that no less than forty out of a thousand could read; but few of these, probably, could do more than pronounce the words of the ancient Syriac, without understanding them. Before night he arrived at Ashitha (avalanche), - so called beeause they are frequent there, - where he was the guest of Kasha Auraham (Priest Abraham), an archdeacon, and reputed the most learned of the Nestorians. For twenty years he had been transeribing their ancient books in his beautiful handwriting; but even he had not an entire Bible. The Patriarch alone is so highly favored, and his is in half a dozen volumes. Thus divided, one has the gospels, another the epistles, a third the psalms, and so on. The book of Revelation, the epistle of Jude, second and third of John, and second of Peter, they did 
not possess, but readily received them from us, on the testimony of other Christian churches, and their internal evidence.

When Dr. Grant told Priest Abraham of the wonders of the press, his keen eye brightened, and he was impatient to see it at work immediately. He begged him to write down his name for a copy, "and mine, too!" "and mine, too!" at once echoed all around the room, He was also very desirous for schools, and said that multitudes would attend, if one could be opened in Ashitha. Dr. Grant estimated the population of this village, at first, as high as five thousand souls; but afterwards put it down at three hundred houses, or three thousand souls. Half of the people spend the summer with their flocks on the mountains, and these only are in danger from the Kurds. The rest cultivate the fields, and labor in other ways at home, and all spend the winter in the village in perfect safety. Just before, five thousand sheep had been stolen near the Habor, by the Kûrds on the other side. But the Nestorians cut off their return to their villages; and thus shut in, they were released only by the intercession of the Emir of Hakkary, who induced the Patriarch to eall back his people. He did so, hinting to them, however, that they might bide their time. And, before Dr. Grant reached Oroomiah, they had driven away from the Kurds four thousand sheep, besides mules, and enough else to make up their loss, with interest.

Eight hours, east-north-east, over the mountains, brought him, on the 22d of October, to Chumba, on the Kab. He rode over the first range, but had a long, steep climb, on foot, over the second. Here he passed one of their summer pastures, in a bracing air, among streams cool as the snow around them. the higher summits already glistening in their fresh winter apparel. Each village has its own summer camp (zozan), and few spend the warm season in the low villages on the Zab, on account of the heat and ferers. Those who do sleep on high platforms (arzaleh), to be out of the reach of mosquitos and sandflies. But, 
pleasant as are these pastoral scene: , Dr. Girant felt it would need no little love to Christ and this people to reconcile missionaries to the thousand privations of a nomadic life; and still it was just such a life that nourished the piety of David, tending his father's flocks in the hill-country of Judea, and Noses in the land of Midian.

At the foot of the first range, he pased one of the many lead mines, where they were busy smelting the ore. From the base of the second, though his knees trembled from fitigue, he continued on foot, along a narrow path, cut out of the face of the cliff, down to the stream, which he crossed on a long, bare pole. His mule fell into the torrent, but, fortunately, withont injuring his medicines. The whole landscape was wild enough, but became truly sublime when the lightning fashed from the dark canopy above, and the thunder reverberated through the glen. But he was safely lodged in the guest-chamber of the Malek (ruler), in Chumba, before the rain began to pour. The storm continued for more than thirty hours. His host, as his name imports, was the head of one division of the large tribe of Tyary, his authority being that of influence rather than executive power. The Patriarch, at this time, like the high priest of old, was supreme, both civilly and ecclesiastically. Excommunication is the sererest penalty he can inflict; and, as it outlaws the offender from society, as well as the church, is greatly dreaded by the people.

Accustomed to see the agricultural population of Persia and Turkey dwelling together, in compact rillages, as the only security from plunder, Dr. Grant was surprised to see the house. of the Nestorians scattered far apart from one another in their narrow valleys. This comparative security he attributed to the high sense of honor among them, which, as in more enlightenei countries, sometimes produces results not quite so honorable. Some years before, a young man in the family of his host began to cut down a raluable tree. His consin forbade him, but in 
vain, and then brought out his gun, and deliberately shot him on the spot. The parents of both were absent at the time; but as, according to their custom, the bereaved father could accept of nothing but the blood of his brother's child, they were both buried in one grave before the setting of the sun.

Again, at a social gathering, a man, in a moment of passion, plunged his dagger into the heart of his neighbor, and the brother of the slain instantly laid the murderer dead at his feet. Such summary justice tends to render crime infrequent; for men feel that, should they commit it, they have little chance to escape. But, as we shall see, even such certainty of retribution does not always restrain their unbridled passions.

The Malek, secluded as he was, had heard enough of other countries to ask about steamboats and balloons, and also whether the English had ships that could sail under water. Dr. Grant was delighted with his desire for information, and longed to respond to the constant call for the Bible, and schools to teach them to read it. The village priest visited him, and was mach interested in his plaus for their improvement. He ate no flesh of any kind, not even milk or regetable oils, by way of attaining to eminent holiness. Such instances, however, are uncommon; but, as celibacy is a part of the vow, it has superseded the few convents that once existed. Similar vows among the females are very rare, and nunneries are unknown.

The next day was spent among the sick, and in social and religious intercourse with the people, - just such work as he loved. Though the village was small, yet from that and the hamlets round about multitudes flocked to see the stranger, whose benevolence surpassed all they had ever known before.

The former wife of his host was a sister of Mar. Shimon, and the only female among them, in her day, who could read. Her memory is precious, and the people loved to speak in her praise. The heart of the lonely missionary was cheered by this respect paid to an educated female, and he dwells with delight 
on a younger sister who followed her example, and was then the only woman in the mountains who could read her Bible. While indulging in anticipations of what would be when these mothers and daughters were not only educated, but converted to God, little dil he think that one then present would realize his hopes, - it may he in answer to his prayers that day for their salvation.

Not quite twelve years after, Mr. Coan was welcomed to this very village by a solitary believer in Jesus. Nazee - for that was her name - had escaped to Oroomiah from the massacre of 1843 , and there, in the female seminary, became, as she hoped, a follower of the Lamb. After leaving the sentinary, she returned to her native village, where she proves the truth of the words of her Saviour: "In the world ye shall have tribulation." Her lovely example reproves the wickedness of her ungodly neighbors, and therefore excites their hate. Her own mother joins them in their persecutions. A dress sent to Nazee from America they tore in pieces before her eyes; and this is but one of the daily insults heaped upon her, for Jesus' sake. Alone and helpless, her very innocence inflaming the anger of savage mountaineers, we need not mention what sufferings she endures. The serrants of Mar Shimon, when they come to the village, treat her with wanton cruelty. No wonder that she hailed the visit of the missionary with delight. Foremost to welcome him, she followed him everywhere, eager to treasure up all that he sail. She would hear from her dear teachers and schoolmates, but, more than all, of Christ. Long after others retired, she remained, till midnight reminded her that, though refreshed by the interview, yet the weary traveller needed rest. Before day, she was again listening, with tears, to his words of comfort. When he rose to go, she followed him to the river-side, thinking of the fresh insults that visit would occasion, after he was gone, and praying that nothing might separate her from the love of Christ. On leaving, he gave her 



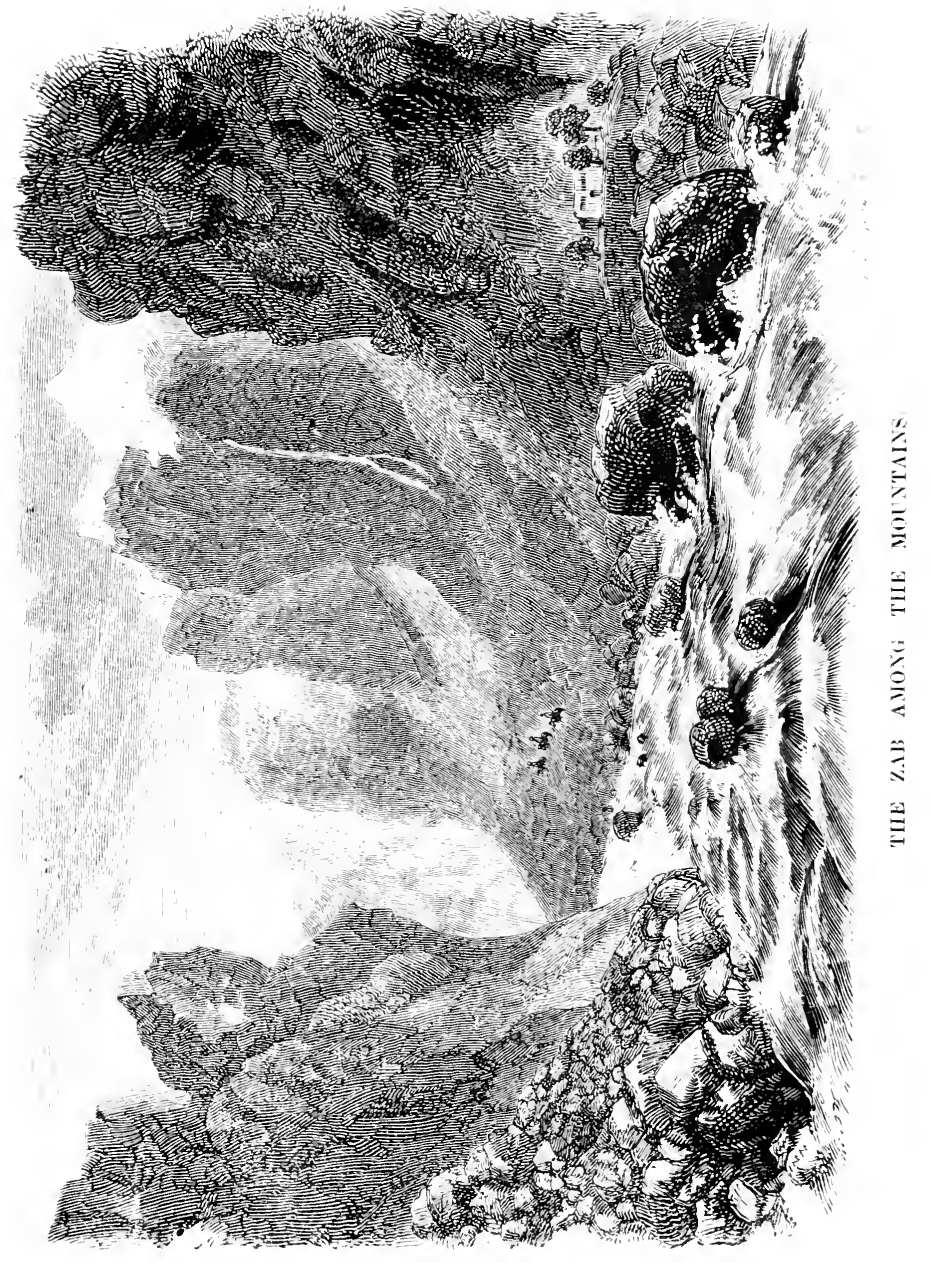


a small eony of the gospels, and pointed to the verse, "Come unto me, all ye that labor and are heavy-laden, and I will give you rest." She began to read, but her voice failed her, and she burst into tears. Kneeling down by the roaring torrent, the missionary commended her to God, and thus left the lamb among the wolves, sad, and yet confident that the Lord would keep her. Yes, afflicted one, God will keep thee! Iou are blessed when men revile and persecute you for Jesus' sake. He will not lead you through any flood of sorrow where he is not willing to walk hy your side, and hold you up with his right hand. And if, as we hope to hear, he gives you the souls of those who thus despitefully use you, in answer to your prayers, you will yet bless him for these distresses on earth, and then glory in them forever above. In the words of Dr. Grant, "However" self-denying your situation now, yet in its results you will enjoy a purer happiness than earth ean give."

He left the hospitable mansion of Malek Ismael about ten o'clock, October 24; and, finding that his mules could not eross the Zab, as two bare poles supplied the place of the usual bridge, he determined to proceed on foot. With two Nestorians to carry his baggage, and the young deacon from Dûree, he crossed the slippery structure, though it vibrated most fearfully over the rushing torrent. Turning to the north, the river dashed along by his side; its roar echoed and reëchoed from the perpendienlar eliffs on either side. These shot up among the clouds, revealing, now and then, snowy pinnacles, still higher, glittering in the sum. When the pass widened a little, a few trees here and there peeped through the sloping pile of stones that reached from the water's edge far up the rocky walls; and wherever the mountains receded to allow of it, two or three houses looked out of their leafy orchards, propped up by terraces that barely allowed room for their foundations. In other places the mountains shade the traveller from the noon-day sun, and he involuntarily lays hold of the roek to prevent his falling into the 
river below. Rain, at intervals, soaked his hair-sandals through and through, but he "travelled all day, with a buoyant heart." Two of his associates, who afterwards travelled this road with mules, found them no great addition to their comfort; for, after being compolled to trudge three-quarters of the way on foot, sometimes, on the remainder, the feet of the mule slipped down between the stones, up to the body. One of them, after turning two complete somersets, from the narrow path along the base of the eliff above, lancled in the river, with all their baggage; and another, in sliding down a steep place, caught his foot between two converging rocks, and sent his rider, head-foremost, into a thorn-bush (Astragalus Tragacantha), from whence he issued nith his shalwar: (Turkish trousers) torn into strips.

Dr. Grant spent the night at Bemeriga, where he was gratified to find the villagers furnish him with a new pair of sandals, for medicine, after they had refused them for money.

Next evening he reached Erek, exhausted by a walk of ten long hours, and was refreshed with a welcome from an old acquaintance, who had come to Oroomiah more than two years before, with an almost hopeless disease, and received, not medieine only, but needful clothing for his journcy back. From that time his benefactor had forgotten him, amid a erowd of others. But, to use his own words, "the promise of God is sure; after many days, I found not only the bread I had cast upon the waters, but everything to gladden me in my weary wanderings. I enjoyed his hospitality, most of all, as coming from Him who crowneth me with loving-kindness and strews my path with mercies."

He started for the residence of Mar Shimon at eight o'clock next morning, and forded the river on a horse, the first he had seen in the mountains, the river four feet deep and about fifty yards in width. The road now began to improve. A gallery was cut in the face of the cliff, and regular steps chiselled in the worst places. It was the regular caravan road from Salmas to Jula- 
merk. In some places, indeed, it was supporter from helow by masonry that seemed ready to gire way under the weight of loaded mules, but, as a whole, was so superior to what he had passed, that he wondered how Yahya Khan should say it was so frightful that a fat horse would there suffer enough in one day, from terror, to make him as thin as a knife-blade! Fatal accidents sometimes oceur, however, when horses meet in its nar. rowest parts. Mar Shimon sent some of his men to escort Dr. Grant to his dwelling, high up on the mountain; and they led him in a north-east direction, till they recrossed the river in sight of it, at the month of a tributary from Diss. The bridge is commanded by the summer residence of Suleiman Bey, and the residence of Mar Shimon is half a mile beyond. Some Kurds here serutinized him rery closely, but did not molest him, while Mar shimon also was examining with a spy-glass his strange visitor from the New World. According to Nestorian geography, the earth - that is, the Old World - is a vast plain, surrounded by the ocean, in which Leviathan moves around, to keep the water in motion; and, as he is so long that his head follows hard on his tail in the operation, they conld not imagine how their guest had climbed over his back to get to them.

At half past twelve the Patriarch welcomed him most cordially to his house, but withont any of the extravagant and heartless compliment so common in Persiil. In the worls of Dr. Grant, "He had been looking for" a visit from us till he had begun to think we would never come. And, now that I had taken such a tedious journey to see him, he could not doubt that I would have come enrlicr, but for the dangers that had prevented my direct entrance irom Oroomiah. 'And now, he added, 'you are donbly velcome, - my heart is glad. You will make my house your home, and me your elder brother. It is a happy day for us both. May your journey be blessed." "

The Patriarch was then tall, but robust, and well proportioned; his countenance at once pleasant, expressive and intel. 
ligent. His ample forehead bore the impress of serious thought, while his large, flowing robes, his Kimdish turban, long, gray beard and dignified demeanor. pointed him out at once as the Patriarch of the East. Were it not for the youthful fire in his eyc, Dr. Grant would have thought him nearer fifty than thirtyeight. He was horn in 1801 ; but his difficult position was enough to make the fiost of care settle prematurely on his locks. To preserve hamony among his own fierce tribes, and with the Kinds around, night tax the wivdom and patience of more celebrated statesmen. It was evident his thoughts were on temporal full as much as spiritual things; for his first incuiries were about their political prospects, the morements in Turkey, and the designs of the Luropean powers. "Why," said he, "do they not come and deliver my people from the Moslem oppression that confines us in these mountain fastnesses?" Dr. Grant adds, "He carries his rifle for the brown bear or wolf, rather than for war. His income is moderate, and he lives in a plain. simple style. Two brothers and a younger sister, with five or six servint:s of both sexes, compose his household. His domestic affairs are mauaged by his sister, who shows herself well qualified for the tark." The Kurds had lately annoyed the districts of Jelu and Tehoma; and, while the doctor was with him, he was called to decille the fitte of two captive Kûrds, from a tribe which hard killed two Nestorians. Blood for hlood is the law, and a tribe is held accountinge for each of its members. Tho Patriarch inclined to mercy, but his people must have justice; and he decided that, as the cintives had in a mamer become their gueste, they might he spared if they would pay the frice of blocul; and so the matter wats rettled.

During the five weeks bro dirant was here, he formed at:cuaintance with Nestorians from all parts of the mountains, and visitel in person the principal villages in the vicinity, endentroring in every possible way to collect reliahle information. Among others, he risited Kala 'd Seringa, a ruined eastle, that 
had been a stronghold in their early contests with the MIoslems. It is perched on the top of an insulated rock, several hundred feet high, and so precipitous it could be reached only by iron pins, driven into the face of the cliff; but, as most of these had given place to wooden ones, he did not risk the ascent. It stands in an opening near the foot of Mount Derrek (mast), which separates Diss from Jelu. It is the highest in the region (not far from fourteen thousand feet), and was then impassable from the snow. Among many patients here, he had one from Jelu, who would have perished on this mountain had not his wife curried him over on her shoulders. The women here perform the labor of men while their husbands are absent, and thus acquire their strength. For, so utterly barren are both Jelu and Bass, that many of the men labor in Turkey during the winter as muleteers or otherwise, returning in the spring to their mountain homes.

Their form of church government is hierarchical; and yet, there being no word in Syriac for bishop, they had to borrow episcopos, as well as patriarch, catholicos, de., from the Greek. This is more worthy of note, as their language was spoken in Palestine in the time of our Saviour, and their Seriptures translated in the beginning of the second century everywhere render episcopos (translated bishop in English) by the word presbyter, or priest.

Having heard nothing from the Prudential Committee since Jeaving Oroomiah, Dr. Grant resolved to return there by way of Julamerk. This required him to visit the murderer of Schultz; but he hoped, by securing his confidence, to open a safe communication between Oroomiah and the mountains; and when anything promised good to the mission he never shrank from it merely becunse it involved personal danger. He had previonsly procured letters to the emir from both the Turkish and Perian authorities, and the Patriarch offered to send his broth $y$ to introduce him. He also took special care to awaken 
neither Kurdish jealousy nor suspicion. He carried little else than medicine, and that he hoped to retain, at all erents. To provide against the loss of his purse, he had secured some gold in a roll of blister-salve. Besides, he risited no mines, and collected scarce a single mineral or plant, lest they should take him for a spy. He noted down nothing in public, and even took the hearings of his compass unobserred.

With such precautions he proceeded on his way, about the 1st of December. On leaving, the Patriarch presented him with a pair of scarlet shaluar, trimmed with silk, and a New Testament in the old Estranghelo characters, written seven hundred and forty years before. His sister, Helena, firnished him provisions for a week, and a pair of warm mittens, wrought by her own hands. Ardent wishes were expressed for his return to labor, with associates, as he had done in the plain, and a thousand blessings were invoked upon his head. The emir had gone from Julamerk to Bash Kala (head castle), two days distant, and thither he bent his steps. Its massive walls were visible in its lofty position, long before he reached the town below. Nurûlah Bey had taken a riolent cold, attended with fever and inflammation, and the doctor was called to prescribe for him immediately on his arrival. He did so, and returned to his lodgings, at the foot of the Castle Hill. In the evening a messenger again summoned him in haste to his patient. He sent back word to wait till the medicine had taken effect. Midnight brought a second messige, that the emir was still very ill, and must see him immediately. Dr. Grant arose at once, and followed him up the winding jath, to the castle gate. The sentinels were sounding the Kirdish watch-cry. The guard admitted him 10 the outer court, through doors cared in iron. From this a seroind iron door led through a long, dark passagge, to the roon where he lay. He was evidently impatient, as well as suspicious. Swords, pistols, guns and daggers, hung on the walls; and the missionary could not but think of the solitary traveller, who 
had fallen by the orders of this very chief. The power of life and death was in his hands, and he was entirely at his merey. "But," says he, "I felt that I was under the protection of One who had the heart of kings in his keeping; and, breathing a prayer for his blessing, I told the chief the medicine was doing well, though he needed a more powerful dose, that, for a time, wonld make him worse instead of better ; and, if he confided in my judgment, he had better take the sererer course. He conscuted, and I gave him an emetic, which he swallowed, after the precantion of making some of his attendants taste it, to see if it were poison. I remained with him that night, and next morning he was much relieved. He rapidly recovered, and I became a great favorite; I must either remain, or else return soon, to take up my abode in the country, where I should have everything as I pleased."

We, at this distance, can hardly appreciate the peril of Dr. Grant on that eventful night, among those men of blood. But his ealm and fearless bearing, the good will that needed not words to declare it eren to them, made an impression that nerer was effaced. Had the chief not been sick as he was, subsequent events show that he would have suspected Dr. Grant as an emissary sent to avenge the death of Dr. Schultz, and so at once put him out of the way. But God's eye was on his faithful servant, and He knew how to order each event for his safety.

The emir is a man of noble mien. His figure is commanding, and his eountenance manly, when not darkened by suspicion and jealousy. Though at first quite suspicious of Dr. Grant, yet afterwards he was very affable, and, on his leaving, made him a present of a horse, in token of his gratitude.

He now joined a cararan to Salmas, and proceeded thence to Oroomiah, where he arrived on December 7 th, after an absence of eight months. For half a year he had not seen a chair, and had long dispensed with knives and forks, eonforming himself in these respects to the customs of the country. So changed was 
his appearance, in his oriental costume, that he was not at first recognized by his native acquaintance. But it was delightful to mingle once more with Christian friends; and his native language never sounded so sweet as when, after a long sojourn among strangers, he heard it from the lips of those who loved the Saviour and his precious cause. Nor was this his only cause for gratitude; along the cold highlands of Armenia, over the sultry plains of Nesopotamia, and through the wild mountain: of Assyria, he had been brought safely through many danger.. Bright prospects of usefulness opened before him ; and, instead of being laid aside from the work he loved, he had been introduced to a new field, rich in its promise of a future harvest. True, it also promised to call him to endure hardness; but he rejoiced in any personal affliction that promised to work out for the church a far zore exceeding and eternal weight of glory. 


\section{H A P T E R IX.}

AINSWORTI - BEREAVEMENT - LETTERS - SECOND JOURNEY THROUQH THE MOUNTAINS - HERTÛSI KÛRDS - ERZRÛM - CONSTANTINOPLE - VISIT TO AMERICA - CHILDREN - THE LOST TRIBES - RETURN TO THE EAST.

During the winter two brothers of the Patriarch visited Oroomiah, and urged the extension of our labors through their country; and Mar shimon wrote, renewing his invitation for Dr. Grant to return in the spring. 'The following is an extract from his letter:

"From the patriarchal mansion, with prayer and blessing, my heart went with you, O Hekim [doctor], the day you went from me; but after I heard of your safe arrival I greatly rejoiced. If you inquire of my affairs, and what I have to say, it is that word which we spoke [that is, his desire that Dr. Grant should return, with associates, and labor in the mountains, as they had clone on the plain]. What I said to you before is what I have to say now. You and I are one, and there is no change in the things you heard from me; and again may you be a blessing, and blessed with the blessings of God and the words of salvation; and may he give you joyful seasons and length of years, and remove and keep from you troubles and disquietudes."

This is quoted by $\mathrm{Mr}$. Ainsworth * _ an English traveller, who entered the mountains in 1840. after Dr. Grant had passed through them the second time, on his return to America - to illustrate the inaptitude of the Patriarch for epistolary corre-

\footnotetext{
* Travels in Asia Minor, \&c., vol. Ir. 252.
} 
spondence. It is to be regretted that Mr. Ainsworth felt it necessary to assiume an attitude of opposition to the mission of Dr. Grant. But the following extracts from the same volume may throw some light on the spirit of his enterprise. Speaking about the American missionaries, he says, p. 248:

"We informed the Patriarch that there were among us many zealous Christians who seemed to have read the Bible rather to invent new doctrines, and rebel against the church, than to give them increase of wistom and holiness; and have preferred following such doctrines, rather than that of the bishops who are appointed to teach the nations."

And again, p. 251 :

"Mr. Rassam [associate of Mr. A.] informed them that if one of these ministers [Congregationalists] joined the Church of England he must be ordained [again], as the church considered them as people who had no apostolic ordination."

There is another account of his interview with Mar Shimon, that may throw some light on the matter. Native eye-witnesses report that he and $\mathrm{Mr}$. Rassam were at first taken for the friends of Dr. Grant, till his hostility to the mission opened the eyes of the Nestorians on that point. Both he and his companion are said to have misrepresented the missionaries after the manner of the Papists (the above extracts from his own pen may indicate the tenor of his remarks), and urged the Patriarch to drive them out of the country, till he began to suspect they were Papists in disguise. Then they changed their tone, and said they were like the Americans in many respects. They offered to open schools, and desired a letter from the Patriarch to the bishops in England. This Mar Shimon refused, on the ground that he had already made an engagement with Dr. Grant. They then asked for his seal, and that also was refused. On this latter point Mr. Ainsworth says, p. 251 : "We spoke to him about writing a letter, which he promised to do, and send it the next day; but he failed in this, and, on being reminded, said to $\mathrm{Mr}$. 
Rassam, 'I do not know exactly what to say. You know my feelings. I am grateful and anxious for the friendship of your bishops, and wish that you would write for me what you consider proper and decent.' This, however, I thought proper to advise Mr. Rassam not to do; and the Patriarch ultimately promised to send the letter to Mosul." Whether he ever did so or not Mr. Ainsworth does not inform us. No wonder, then, that the extract seemed a poor specimen of letter-writing, especially as the following description of his reception among the people affords such il contrast to that of Dr. Grant. After stating that quarters were assigned them in an Armenian church, near Julamerk, he says, p. 246 :

"The people, for two days, had the extreme satisfaction of worrying us till we had nearly lost all patience. We were never for one moment, night nor day, without a number around us, whose only amusement was to examine all our things, - to pass jests, and fling epithets of scorn, upon their visitors."

Nor is it strange that, after such an errand into the mountains, Mr. Ainsworth should pass through Oroomiah without even calling on the missionaries, because, among other things, he had "only provided himself with such clothing as the necessities of the journey would require," and he " had imbibed quite a horror of the confinement of a hoise on the hot plains, from so long breathing the pure air of the mountains." - Tol. II. p. 304.

His remark, page 254 , that "It is very remarkable that no mission was spoken of among the mountaineers till after our arrival at Constantinople," has been sufficiently answered in the foregoing pages. Such a charge, even had it been true, comes with a very barl grace from one sent into a field already explored and occupied hy a missionary society, to oppose its quiet labors in preaching the gospel. But, when Messrs. Smith and Dwight were instructed, in 1830, to " direct their attention to the Nestorian and Chaldean Christians of Kurdistan" (see their Travels, vol. Ir. p. 175), and were only prevented visiting Mar 
Shimon by the united representation of English residents at Tabriz that the region was "entirely inaccessible," and when Mr. Perkins was instructed, in Sept., 183.8, "to go to Julanerk as soon as may be, lest interested and perterse men shonld prejudice the mind of Mar Shimon against him," one wonders how Mr. Ainsworth can think it so remarkable that no mission was spoken of among the nountaineers till 1839. On the other hand, we may be permitterl to think it rery remarkable that, when Mr. Perkins wals sent, in 1833, not to the Nestorians of the plain, but to the Nestorian Church as a whole, and told that his residence "for the present" only was to be at Oroomiah, Mr. Ainsworth should be sent by "The Christian Knowledge Society" on such an errand, in 1840. It may be well to add, in this connection, that, when the mountain mission was established separate from that on the plain, it was declared publicly, in the instruetions given to $\mathrm{Mr}$. L. in 1842 , to be "distinct for reasons purely geographical;" and when it was broken up, two years afterwards, the design was not to abandon the mountain field, but only " to enter from the eastward, instead of from the uest," as stated in the letter of Dr. Anderson authorizing the missionaries to withdraw from Mosul.

But to return to Dr. Grint. As the influence of the malaria of the plain on the system through the summer continues to develop itself during the succeding winter, his absence throughout the warm season rendered his residence at Oromiah this winter comparatively pleasant. Still his health was not recovered, and the homeless condition of his children required his somen, for a time at least, io bis native land. December 29 he thus wrote to his eldest son :

"Nothing gives me such pleasure as to hear good news from my dear children. I hope I shall hear again from you soon; and, what is more, I hope to see you both before the end of another year: Yes, my dearest son; you will again meet your affectionate father, so long absent from you in this distant 
land. What a happy meeting it will be! Would that I could see you to-night, and press you to my heart! How much I shall have to say to you, and yon to me! And you will see your brother, Henry M., and your two little sisters, Judith and Mary. What a company of us there will be! Let us see: Seth Hastings, Edwin Hodges, M. Martyn, Judith Sabrina and Mary Electa, and your dear father. You will have a great dea! to tell about your studies, yourself, your brother, and all you have seen and experienced. I, also, will have much to tell you about these countries and this people; and perhaps you will wish to come and live here, and do them good. I should love to write many things about my journeyings in these Bible countries, so that you might love the Bible more which tells about them. But I hope to see you soon, when we will talk of them all."

That loving parent was soon to be called to new trials, in the loss of those little daughters. Mary E. died Jan. 13, of influenza; and, two days after, the aflicted father thus wrote to Mr. Merrick :

“A year ago yesterday my dear companion entered into rest: and yesterday one of her little twin-daughters, our sweet Mary was laid in the cold grave by her side. Her spirit departed the evening before, and, I cannot doubt, has gone to the same blest mansions her dear mother so recently entered; for, without daring to decide on the final state of all who die in infancy, neither of us will doubt the validity of the gracious covenant to believing parents. What a precious consolation that we have such a covenant to pleas in behalf of our children! Were it not for the consolations of the Bible, what should we do? $O$, what a world of trial! But hush, my soul! - it is the Lord's doing. I feel sure that our kind heavenly Father does all things well yes, for the rery best - concerning us. But the heart will bleed when so often torn. My father, brother, wife, child, - all laid in the grave since I have been here; and as many more 
had gone before. Vain, fleeting world! 't is not our home; but thanks, eternal thanks to God! we know that if this earthly house oi tabernacle be dissolved, we have a building of God, a house not made with hands, eternal in the heavens. We know, too, that the Lord afflicteth not willingly, but for our good, that we may le partakers of his holiness. O for grace thus to improve these aftictions! Little Mary was a delicate flower, a breath passed over her, and she is gone! I often think of your kind care of her dear sister. when so low at Tabriz. The Lord reward yon! She is now quite well, and exceedingly cheerful."

So he wrote then; but, twelve days after, Judith Sabrina followed her twin-sister to the grave.

It was a great comfort to him to be with them during their sickness; and Providence kindly ordered that it should not oecur during his absence in the mountains. Is not missionary experience full of stch mercies? The remark was often made, in that missionary circle, that "no one could bear these trials more like a Christian than he." How he bore them may be further seen in the following letter to his mother, Jan. 30,1840:

"My Dear Yother: How often are we called to realize that we are strangers here! But we are pilgrims to the city of our God; and, though the way seem dreary, as one after another of our eompanions are taken away, bright glimpses of heaven cheer us on, and we feel that we are nearer home, sweet home. But for the prospect of repose in our Father's house, how could we bear our trials in this vale of tears? It seems as if my short life had been a continued scene of trial and bereavement. The less of my dear: father, three sisters and two brothers, was a cup of which you, dearest mother, drank the bitterest dregs; and now that I call to mind your trials, I might feel reproved for naming my own, did it not serve to convince you that your absent son knows how to share your sorrows. Though I cannot 
know all a widow's solitude, the removal, onee and again, of the best of wives, has taught me something of the emptiness of earth; and now I know a father's, if not a mother's sorrow, in parting with beloved ehildren.

"The mortal remains of my twin-daughters now sleep by the side of their dear mother. Sweet babes! lovely in life, and in death not divided. What a precious group! - the mother and her infant daughters awaiting together the morn of the resurreetion! Far from home and friends, they have found a grave on one of Persia's loveliest plains, now dearer to me than ever; but their inmortal spirits are with Jesus in our Father's house, gone home a little before us.

" $O$, mother! does not your wounded heart yearn for the sweet repose of that blissful abode where God our Father, Christ our Saviour, your sainted parents, the partner of your earthly life, your children and grand-children, will all welcome you home? Perhaps, ere this, you have entered on that rest. If not, we shall both go soon. Are we ready? Surely we have had enough to wean us from this vain world! We have had admonitions, too. I only wonder we are spared so long. Soon shall we depart; nor would we stay when God shall call us hence. Still, we should not be tired of this world while God has work to employ us here.

"I am loking forward to the day when I may once more see the face and hear the voice of my dearest mother; but I ean hardly realize that we shall meet this side the grave. Should I not live to see you, accept my warmest thanks for all your kindness - your unwearied, motherly kindness - to me and my orphan sons. Nay God reward you!"

To his children he writes, February 12 :

“Mr Denrest Gimbren: I wrote to Henry not long since, and told him I hoped you would soon have the pleasure of seeing jour two sweet little sisters. I anticipated the joy it would 
give you to meet them for the first time, but they are gone. Your brother Henry I hope you may see; he often talks about going to America to see you. Do you wish very much to see him? Would you like to teach him to read? He has no school, as you have. If you would be useful or happy, improve your opportunities for learning. Study to be wise, and leirn to be good. Nothing will make me so happy as to see you trying to do good. If you would be haply, you must try to make others so. It is this that makes missionaries so happy. They find it very painful to be separated fiom friends, and especially from dear children, as your father is from you. But we are happy in doing good to others."

Circumstances connected with the relfare of the mission detained Dr. Grant in Oroomiah till the beginning of May. Then, anxious to increase his acquaintance with Mar Shimon, to obtain additional information abont the mountains, and especially to remove any remaining doubts about the practicability of travelling there, instead of taking the usual road to Erzrim, he resolved to pass through central Kûrdistan, on his way home.

He left Oroomiah, May 7 th, with his little son, then four years old, accompanied by Mar Yohanna and Mar Yoosuf. At Salmas he failed to find the weekly caravan for Julamerk, as the government had forbidden the exportation of the wheat it usually carried; and, although on that account he feit, that the time was not a fararable one, yet, lest any should take ocrasion, from his not going, to lefer doing anything for the mountains, he determined to proceed, wilh a single marmed footman from Yahya Khan. Tro brothers of Mar Shimon, with some Nes. torians, were thus cmboldened to venture back from their winter's sojourn on the plain, and all set out together. The emin' was absent at Van, but Dr. Grant shrewdly argued that while the Kûrd was in the power of the Turks he himself was all the safer among his people, who would naturally fear that any evil done to him would be revenged on their chief. 
In a letter to Mr. Stocking, dated Khosrova, Hay loth, he cays: "Do not fear on my account. The Lord will take care of me, and of his own work among this people. With my auticipations of a glorious display of grace among the dear Nestorianz, 1 am not anxious to be dismissed from toil. I would live to see His chariot-wheels rolling over the highway which shall be from sissyria, though I shall rejoice in it none the less if I behold it from a higher eminence. To God I can safely commit my life, and all most dear to me on earth. I never saw Henry more happy than now. He enjoys his rides and his visits very much, and endures the journey with quite as little suffering as his futher. Though weak in body, I feel 'strong in the Lord;' 'Jehorah is the strength of my life,- of whom shall I be afraid?' Report says Ibrahim Pasha is marching against Geoigia, and Russia is preparing to meet him on the Aras. Wars and rumors of war's; but be not troubled, _ Gop reigns. The Lord wateh orer you and the dear missionary circle, who will not forget a lonely pilgrim in his wanderings."

His way to the mountains was so obstructed by snow, that he had to sleep near their summit, under the open sky, with the thermometer below zero. Providentially, the Patriarch's brothers had some carpets, which made them comfortable till three o'clock $A$. I, when they resumed their joumey by the light of the moon.

On descending to the sompes of the Zab, he found the upland valleys dotted with the black tents of nomad Kûrds, who are more to be dreaded than the other tribes, but lassed throngh the midst of them unmolested, to Bah Kala. From thence he reached Julanerk, on the evening of the second day, thongh the road along the Zab was still obstructed by the remains of ara= lanches. Into one of these his horse fell, and threw him and his little son into the snowy, but providentially without injury. Once or twice afterwards they had similar falls, though he dis: mounted whenever danger was apparent. 
The ascent from the river to Julamerk is truly grand. The road climbs in a zig-zag line up the face of the mountain, till the traveller looks down almost perpendicularly one thousand feet. The roar of the waters rises from below, reecchoed by the snow-capped mountains sound about; while the castle, from it: lower eminence, looks sternly down the ravine, reminding the wayfarer how much the violence of man adds to the natural difficulties of his rugged path.

The bridge to the residence of the Patriarch was swept away a few hours before his arrival, so that he could not visit the tribes on that side of the river, as he had intender. But he spent ten days with Mar Shimon, then the guest of Suleiman Bey, in the castle of Julamerk. His impression of the importance of the mission to the Mountain Nestorians gathered new strength in this visit, and the mudebbir joined the Patriarch in urging his speedy return. He regretted that he could not at once begin his labors among them; but he felt encouraged by the fact that while the year before, on his entrance from the west, Providence had rendered that route safe by the subjection of Amadia, now also the emir was on his way back from Erzrum, pasha of the region he had hitherto governed as an independent chief. "But," says he, in a letter to Dr. Anderson, " we must not expect the great work to be achieved without rigorous effort, and, perhaps, severe trials of our faith." He al:o recommended the oceupation of Mosul, in case of the interription of communication with Oromulat for " these lands may soon the the theatre of fearful commotions, so that what we to for them should be done at once, and with all our might."

After he was all ready to leave for Hosul. a pain in his chest delayed his departure, till he did not dare to take that ronte. lest he and his little son shonld fall victims to the hot desert winds of Mesopotamia. He had again yisited Julamerk, and resided safely with Suleiman Bey, who headed the party that murdered Sehultz, and now seemed, by special kindness to him, 
endeavoring to blot out the memory of that deed of blood. This proved the practicability of travelling in these regions, full as much as another journey through the safer district of Tyary would have done; and, as he had a desire to see what facilities Van afforded as a point of access to the momtains, he resolver to go that way to Constantinople.

It wals lite in the afternoon of the 25 th before he left, for Suleiman Bey, even after he was ready to mount, constrained him to stay to partake of a repast, while his mother prepared some bread and honey for the road. She gave her favorite, Henry, a bag of nuts and raisins, with a small loaf of sugar. The Patriarch's sister also sent a lurge supply of holwa (honey, flour and butter, simmered together), rolled up in bread; and his mother sent bread, cheese and eggr, - kindnesses to appreciate which one needs to travel in those mountains, and that, too, at a time when, as now, the scarcity ahmost amounted to a famine. The chief had already given Henry a small sum of money, and his mother hung a gold coin round his neck, as a parting gift. "Such," says his father, "were some of the kindnesses the Lord put into the hearts of this people to show to the pilgrim missionary in this land of violence. May He reward them by the gift of His word and spirit, and make me the means of leading them to the Great Physician!"

In descending to the river the road looked more dangerous than before, and he was glad to walk, rather than trust to the mule, that, by one false step, might dash them in pieces on the rocks below. At sunset they encimped among the rocks, with the roar of the river for their lullaby. The stars shone bright in the clear night. The noise of the rushing waters was more sonorous in the still air. Three Kinds stretched their brawny limbs by the blazing fire. But, though the hour and place were suited to deeds of darkness, that parent found it sweet to feel that God was presen and know that his angel encamped round about them. 
Next morning they rose with the sun, from refreshing sleep, and, after following the river some miles further, ascanded a tributary, on the right, to its source, among the mountains.

Near the summit of the first range, they rested in a grove of willows and wild-pear trees, just opening into blossom. An hour further, they breakfasted in the church porch of a Neriorian hamlet, - one of the half-score villages of Berwer Shawina, all of which contain scarce two hundred houses, and are miserably poor. Their subjection to the Kurds explains their porerty. Last year, six men of this small hamlet fell in the defence of their flocks from the nomad tribes. At noon they reached the village of Talhr Agha, chief of the Pinianshi Kurds, a tribe numbering some thousand families, and nominally subject to the emir. Part of them live near Tehoma, and are a bloody and lawless clan. Here they spent the night, and were nowhere entertained more hospitably. They were treated with coffee and sherbet; and, besides a dinner of excellent pilav, were furnished, after breakfast, with a basket of roasted eggs for the road. Perhaps the doetor's prescriptions for the chief and two of his harem may explain such generous hospitality.

In one of the Kûrdish villages which they passed, a woman gave him some of their native socks in return for medicine. An hour before sunset they reached a large camp of the Hertûsh Kûrds, the most noted robbers in the region. Their chief came out and gazed at the strange sight of a Frank dress; but suffered them to pass unmolested to the next camp, where the doctor wats not unweleome, as the chief was ill of a fever, and many suffering from ophthalmia. A tent was assigned. him, forty feet by eighteen, with one side open, and a web of reeds set up on edge round the other three; the black hair-cloth above was surported by a number of poles, and secured by cords fastened to pins driven deep in the ground. One quarter of the tent was fenced off for the lambs, which are not let out to the flock till 
the Kurds have secured most of the mills for themselves; and, at: with them this is valued more than the wool or flesh, they wonder that we should never milk our sheep.

Three hours' ricle, by a new road, brought them again to Bash Kala, on the $29 \mathrm{th}$. In the valley of a small creck they stopped a few moments, at the spot where Schultz fell. The sons of an Amenian in Bash Kala bured him where he hay, and a small airn marks the grave. One of his servants was killed in the town, lest he should betray the murder of his master. But the news soon reached Persia; and when redress was demanded, the agent who did the deed was slain by the very chief who had ordered him to do it. But in this, too, appeared the good hand of God ; for, had that man been living, he would have suspected Dr. Grant to be the avenger of blood, and in all likelihood have billed him also, to avoid the justice that he feared.

Schuliz had carried away specimens of the yellow mineral from their orpiment mines, and they suspected ho had found it to contain gold, and so would induce his king to take possession of their country. Major Rawlinson attributes his death to his taking an Afshar guard from Oroomiah, instead of a Kûrdish one, offered him at Ushnei. He was thus regarded as a govermment emissary, discovering the best route for the approach of the Persian guns.

Dr. Grantspent a ruiet Sabbath in Bash Kala, though, from the great scarcity, he could hardly get enough of coarse barley bread to satisfy his hunger. This quiet Sabbath in Bash Kala is commended to the notice of those who find so many excuses for travelling on that day in our peaceful land.

IIe left late in the afternoon, June 1st, and two hours after, the party was alarmed by armed horsemen on the mountain above, vanishing as suddenly as they appeared. Some got their weapons ready for defence; but his Nestorians concluded, with Dr. Grant, that it was better to be robbed, as they expected to be, than to kill. As fight was impossible, they kept on, pre- 
pared for the worst, and longing for the protection of the three servants of the emir the mutsellim had promised to the doctor. The supposed robbers proved to be these very protectors.

They crossed a snowy ridge to the castle of Hahmudiyeh, and thence journeyed to the ralled town of 'Tim, overlooked by it: ancient castle. The extensive garlens around form the summer residence of many of the people; and the lake abounds in fish, though its water is so alkaline the peonle use it to make soap. Its surface is about four hundred and serenty feet higher than the Lake of Oroomiah.

He remained ten days here, and had repeated interviews with the emir, then on his way home. He found him still friendly; though, he cautiously adds, "how valuable his friendship will prove, remains to be seen." The subjugation of the Nestorians Tas the main object of his visit to Erzrum, and this alliance with the Turks.

In writing from this place to his friend Mr. Stocking, he says: "Henry is as fond of his horse as ever, and, I trust, may be benefited by his long journey, - though I sometimes feel anxions, when I think how liable we both are to sickness and accident. But I try to trust all in the hands of God. From here to Erzrum the whole country is suffering from the famine, and the Kurds may be impelled to robbery, if they cannot subsist on the products of the dairy. I shall take what bread I can from here, and must trust to Providence when that is gone."

On his way to Erzrum he met with a pleasant illustration of the ralue of English protection. A horse was stolen from the party, one night, in the tent of a Kûrdish chief; but, on his threatening to complain to the E!n?:; ronsul, it was at once restored.

His only suit of clothes were ragged enough, after the hard usage of his journey, to satisfy any adrocate of missionary economy; but this did not prevent a hearty welcome from his friends at Erzrûrn, both English and American. Among the 
former were Dr. Riach, consul Brant and Col. Sheil ; and here he met, for the first time, Dr. Wright, who still lives to fill his place in Oroomiah. He had much of counsel and advice to gire to his succesor, who has not forgotten, to this day, the impression he then received of the doctor's energy and devotion to his work. Fhey called logether on the gentlemen of the Persian embassy, then in Frzrum, and one of them, observing Dr. Grant; erect and commanding person, remarked, " 1 good soldier was spoiled when that man became a miscionary." He should hare said, "A good soldier was promoted to higher service."

He left Erzun June 26, favored with letters of introduction to Lord Ponsonby, from his friend Col. Sheil, her Majesty's ehargé d'affaires to Persia; and, at Trebizond, was right glad to exchange the saddle for a quiet seat in the cabin of the steamer to Constantinople, - grateful for that more than paternal care that had brought him and his little son safe through the perils of their arduous journey.

In Constantinople he received from Lord Ponsonby the warmest assurances of his readiness to protect our labors in the mountains, as well as of his lively interest in the Nestorians. From Commodore Porter he, both then and previously, received many favors. Even now he had fears that the new relations of the emir to Turkey would prove unfavorable to the Nestorians, and to missionary labor among them. But, while feeling that storms were needed to clear the political atmosphere, he also felt that " He that observeth the wind shall not sow, and he that regardeth the clouds shall not reap."

From Constintinople he proceded, by steamer, to Snyrna, where he embarked on board the brig Franklin for America, and wrote the following to Dr. Wright, while sailing down the Gulf of Smyrna, July 26 :

"Though, in one sense, you are more solitary than you will always find agreeable [the good doctor has since married], I trust you may, as did once a godly minister, make Christ's cause 
your chosen bride. Your work is most interesting, and I trust you will do it far better than I have done, and, especially, be at mach better physician of souls. In all respects let your aims le high; and do not copy after me. Most unft am I to be even a hewer of wood and drawer of water for the great temple. If I can get moie skilful workmen into the field, I shall feel that I have not lived in vain. Four whole field must be brought under immediate cultare. If there are obstacles, we must have more fitith, more zeal, and liore love."

He landed in Boston Oct. 3, 1840, after a pasage of serenty days, only to labor for his beloved Nestorians in other ways. While in this country he spent as much time as possible with his childien, who were much in need of his presence and care. It is one of the sorest trials attendant on the separation of the missionary from his children, that, while his heart yearns after them, they learn to regard him as a stranger, and transfer to others the affection that, of right, is his. Thoughtless persons, too, let us not think they do it intentionally, - suggest to the childien that their parent ought to be with them, and that, if he cared for them as he should, he would not leave them. Thus, too often, the loving heart, hastening to embrace those whose absence has been its daily grief, is orerwhelmed to find indifference where it looked for all answering affection.

He found a pleasint home in Utica for the little stranger from Persia, secured what he hoped were permanent homes for his elder sons in Christian families in New York and Clinton, and made provision, from his own scinty funds, for their liberal aducation, hoping that one day God would bring them to share his missionary labors. Frequent athesses to the churches, which will nerer be forgotten by those who heard them, and would have been more numerous had he not str tined every nerve to get back to his work as soon as possible, - important conferences with the Prudential Committee, and the publication of his work on "The Tost Tribes," ocenpied every moment of his time, 
and gave him little opportunity to recover the health he so much needed.

In his book, besides giving an aceount of the Nestorians, and his journeys in Kurdistan, he sought to identify them with the ten tribes of Israel. Of this work he says himself, in a letter to a missionary friend: "I regret that I could not devote more time to its preparation; but I did not feel at liberty to let it interfere with more direct missionary labors. The last part, in particular, is too much hurred; but it may lead to inquiry and more thorough elucidation by those more eompetent, and if so, it is well." Yet the book was very popular, both in this country and in England, and eliciter much discussion. It yielded him also a small income, at a time when, but for the aid thus afforled him, he might have been compelled to return and provide otherwise for the support of his children.

While here, his ardent appeals awakened a deep interest in the people so dear to him; and he had the pleasure of seeing two missionaries, with their wives, - Rev. Messrs. Hinsdale and Mitchell, - embark, January 18th, 1841, for Smyrna, on their way to the Mountain Nestorians.

Writing to $\mathrm{Mr}_{\mathrm{r}}$. Stocking, March 14, 18t1, he says : "There is an increasing interest felt in our mission. Prayer will be offered, and it will be heard. Doubtless we shall have a hard struggle with the powers of darkness; but the work is the Lord's, and will go forward. He may suffer our faith to be tried; but let us he steadfast, knowing that onr labor is not in vain in the Lord. I might awaken an increased interest in our mission, if I remained a few months longer. I have full and attentive houses wherever I go, and have engaged to speak in two churches in New York city to-morrow afternoon and evening. I have also urgent calls from important places in this and other states, but must decline them, and make my voice heard from my field of labor."

After a brief sojourn of six months, every hour of which, not 
spent on a bed of sickness, was fully oecupied, - indeed, he had not time to visit many of his relatives and personal friends, - he hastened to return; and the same Hand that shielded him from men of blood in Kurdistan held him back when all his plan were laid to sail in the ill-fited President. He left by the Cunard steamer of April 1st; secured the copyright of his bootin England, which was published on thesame dary in London ant New Tork; and, hastening through France, embarlied at Marw seilles, and arrived at Constantinople on the 1tth of May. Thear, having procured firmans, and made other necessary preparation, though scarcely recovered from a severe cold, he left, about the end of Miay, for Trebizond. He had intended to go to Aleppo, and accompany the reinforcement to Mosul ; but late advices fiom Syria rendered it probable that they would be detained there till the autumn by disturbances in the interior; and, with the approbation of his brethren of the Armenion mission, he re solved to $g_{0}$ at once to the mountains, and make preparation. to introduce his associates to their future field of labor.

Before learing Constantinople, he thus wrote, concerning hi: health, to Rer. W. Jones, May 27 th :

"I am anxious to get into the mountains as soon as practicable, but I an providentially detained here by ill health. I was to have left last week, but the brethren advised me to delay. I am now better, on the whole, but the physieians join with the miscionaries in urging ne to delay another week, and I have reluctuntly conventel. I trust then to be able to proceed; but I camnot concenl from myself that my hurried risit to America has not so invigorated my constitution but that I ought to be ready for my last change; and I would recommend your station to take into serious consideration the question of sending one of its nembers with me into the mountains the present summer, that, whaterer advantages my acquaintance with the people has given me may be, as fur as possible, transferred to you, and thus no arivantage be lost to the cause in case of my removal. Do nnt 
think, from these remarks, that I am dangerously ill; but life is always uncertain, and nothing should be risked on the life of one man, and he the tenant of a shatterer tenement."

Thus, he did not count his life dear unto him, in comparison with the success of his work. The reader will bear in mind this account of his health, as he follows him through the toil and hardship yet to come. 


\section{CHAPTER X.}

IHIRD VISIT IO IHE HOUXTAYS - RLHNISCENCE - DERTISHES - SUMARY JUSTIO :- FAMNE - TRATRLLING IN TIL EAST - FALEE ALARM LACOCXTEE, WITI KÛRDISH ROBBERS - VAN - TREACIERY OF KÛRDISI

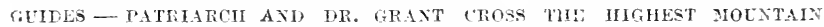
IN KÜRDISTAN - JELÛ - BASS - TEIOMA - SCRIPTURAL ASSOCIATIONS - NARROW ECAPE - DISCOYERT OF ANTUCITIES-WINE-DRINKING LABORS IN ASHITHA - NEWS OF DEATI OF MR. AND MIRS. MTTCHELL -

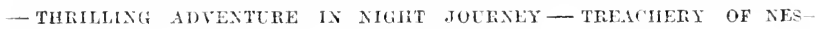
IORIAX GLUES - ARALS - AIRIVAL AT MOSCL.

Ar' Trebizond he makes this entry in his journal, Jume sth :

"I hat thus far been borne so rapidly fiom one exciting scene to another, that I had little time to dwell on the trial of a second separation from my native land; but, now that I was alone, on a rugged pathway, that led me fir away from civilized life, I fu!t once more a pilgrim in a strange land." In such a state of mind, many a tender recollection was awakened by the sight of the spot where, six years before, he pitched his tent, for the first time, with the loved one now in heaven. She had listened with him to that nurmuring stream, had shared his relight in the wild mountain seenery, and together they had bowed there hefore the merey-seat. Now, she was not; his chilGen were far atwy, and he alone; and yet not alone, for Christ was with him, and in his heart he rejoiced in the privilege of ; uffering for His sake. The rame astle of the Deribeys (chiefs cit the valley) lookel town thom its boity wag, and the fields in the vale wayed in the rim rendure of early sumer, reminding lim of one who used just such a scene to strengthen the faith of his disciples, - Watthew $6: 28-31$.

$\mathrm{Bu}^{2}$ these thoughts were dispelled by a storm that had long 
been gathering on the mountains, and now burst, with lond thunder, over the valley. As evening drew on, he found shelter in the post-house at Jevizlik. A coarse nut was spread for him, ant colfee served, without sugar or cream, in cups not so large as an ego-shell. A dry bed was not to be had; and, after sharing his supper of coarse, black bread, yoghoort (thick, sour milk) and eggs, with two hungry dervishes, he lay down, wrapped in his wet eloak and the quilt he carried on his saddle. These men, under a coarse exterior, possessed considerable intelli. gence, obtained in their extensive wanderings. As they "dipped with him in the dish," they complained of the Sultan as an anostate, and bewailed the religion of Islam as passing awa with his temporal power. So Allah had decreed, and they must submit. He asked them when it would pass away; and they replied about the end of 1 . II. 1260, which corresponds with A. D. $184 \pm-5$.

Next morning, his ascent of the mountain was through rain and mud, as on his previous passage; and, at a khan where ho stopped to rest, he declined the honey they offered, as experience had taught him that its nareotic quality, mentioned hy Xenophon, was not altogether fabulous.

He reached Erzrum on the 12th, and, as travelling alone was unsafe, he waited there ten days for a caravan. June 14th, he wrote thus to his brother Tra: "Goodness and mercy have followed me all my way. Miy health, which was not good at Constantinople, is better now. In a few days I hope to leave for $V$ an and Julamerk, and, after visiting the mountain tribes, to introduce my missionary companions to their new home. The Lord will take care of me while he has work for me on earth. May I then be prepared to enter into rest. It seems as if the rest of heaven would be peeuliarly sweet, after the cares and toits of a missionary life. The work never seemed more arduous, nor the grace more wonderful that employs one so unworthy in a rause so glorious. My journey is not entirely free from peril ; 
hit I shall use caution, and trust that the who has so often preserved me will still be a very present help in trouble. May His presencs be with all my dear, dear friends and children, in my native land!"

And again, Tuesday, 15th:- "I have just returned from the palace of the Pasha. He is trying to intinidate evil-doers; and, near one of the city gates, I was horrified to see an illfated Kurd still on the gallows, the third day after his execution. He had been guilty of robbery and murder. Others had been bastinadoed till they were norly dead. One is to receive a thousand blows on the soles of his bare feet, at the rate of two hundred a day, for five days. The lawless state of the country, doubtless, calls for sererity, but the heart bleeds at the sight of it. O for the blessings of an enlightened Christian gorernment! Would that Christians in America knew how much they owe to the gospel, for surely they would then do more to diffuse it through the world."

He left for Van on the 22d, with about forty Kûrds, Turks and Armenians, and no attendant but his muleteer, whom he hired, with his two horses, for about nine dollars. One of these he rode; the other carried his medicines, books for distribution and provisious for the way; for, owing to the famine that still prevailed, no bread was to be had on the road. Many of the people, the year before, told him they had not secn bread for two months; they then lived chiefly on vegetables boiled with yoghoort, and looked pale and diseased, and now it was much worse. Many bad perished of hunger, and thousands more hat fled from the region. The growing crop promiced well, but, for want of seed, little grain had been sown. Famine is usually followed by the plague, and it had already broken out in some of the villages along the road. On this account he did not enter a house, sare once, when he was driven in by a violent storm of rain; and then he learned that a dead body had been carried out of $0^{-a}$ room shortly hefore he entered the other. 
Multitudes perished through the whole region from Eizrum to Mesopotamia. War, too, further on the road, would have arrested his steps, had he been later ; but God kept him from the pestilence that walketh in darkness, and the destruction that wasteth at noonday.

We will now sit down by him, in the road, on the third day fiom Erzium, and glean a sentence here ant there from a letter to the late Rer. W. Gridley, then the guardian of his second son. "I write you, seated upon the ground, among the mountains of Lurdistan. My rmbrella, resting on some of the baggage of the cararan, affords a partial shade from the noonday sun; but, partial as it is, it is all within reach, for neither tree nor house is visible in any direction. The horses are grazing around me, each with an enormous pack-addle on lis back, that is nerer removed, except when they are curied. Slung orer these, in two equal parcels, they carry a load of fiom three to four hundred pounds. You would be surprised to see them carry such burdens, for hundreds of miles, over rery steep mountains, on roads worse than any you ever saw; for in all this region they have neither wheeled-carriages nor carriageroads. The caravin horses often wear bells; so that "Holiness to the Lord,' written on the bells of the horses, would seem to denote the consecration to God of the merchandise they carry. The khans, where they stop for the night, - when they can find them, - are nere stables, with one end usually a little higher than the rest, anc railed off, to separate the men from the horses. The triveller is fortunate who can procure a little of the plainest fuod ; but a bed is not to be thought of, except as he carries it with him. In winter, if the breath of the horses does not suffice, you are w ... by a smoky fire of dried manure; and in stimmer tie $1^{1, \ldots e c}$ is absolutely intolerable, from the myriads of fleas. This noming we mounted at four o'clock, but nothing could induce the bash katurjee (head muletcer') to leave a green meadow, which we had reached at half-past seven; 
and here we must wait in the hot sum till three o'clock, when we shall go a little further, and encamp for the night. It is trying to proceed so slowly, but there are no post-horses on this route, and it is too perilous to travel alone.

"June 25. - Last evening we forded the Aras (Araxes), and encamped upon its banks; the water was midway up the sides of the horses, but we raised the loads by means of bags of chopped straw piled under them, on the pack-saddles, and so got orer safe. During the night some of our horses strayed or were stolen by the Kurds, and the muleteers remained to seek them, but the rest of us set off soon after sumrise, though our danger was increased by the separation; for, with most of res, it was a choice between danger and starvation. After a ride of thirty miles, I am getting ready to sleep, as usual, upon the ground. I have a rug and quilt, to which I add my cloak, and, thus protected, sleep very comfortably, - though the dew is so heary, my covering looks in the morning as though it had been exposed to a shower. But the sun is setting, and I must bid you good-night, and see if I can get some rice boiled for my supper. It were cruel to wish you here to see us; and yet I wish you could look on this novel seene and motley group, with. out the hardship and exposure of the journey. Still, the pres. ence of the Saviour sweetens every care, and I trust you will not cease to pray that it may abide with your pilgrim brother."

That night, while encamped near some salt springs, he was roused by a loud seream, and found all in the greatest consternation. His first thought was that they were attacked by the Kûrds, who had been hovering about for two days; but, instead of Kûrds, only a horse had quietly whisked his tail in the face of an Armenian priest, who woke up screaming, and the rest, not knowing why or wherefore, followed his example. As Dr. Grant was satisfied they would now set a wateh, according to his previous advice, he lay down again and slept quietly.

The next night he slept under the Roman walls of Malas- 
gird, not far from the famous battle-field where Alp Arslan, with forty thonsand Turks, defeated the Greek emperor, Romanus Diogenes, at the head of one hundred thousand soldiers, and took him prisoner, A. D. 1071. The town is small, and now almost dejopulated. Thence, to Asnawak, his road lay mostly over a desolate waste, covered with igneous rocks from the extinct voleano of Supan, which has a distinctly formed crater on its summit. On the day following he passed over the most dangerous part of the road, and the fears of his companions were increased by the reports of recent robberies, on the road before them, by a party of twenty-five mounted Kûrds. For several hours they kept near the shore of Lake Van, and saw no danger till they crossed some hills to the plian of Ardish. Here a score of Kûrds suddenly appeared, half a mile off, between them and the lake. They sat still upon their horses, while one galloped forward to reconnoitre the travellers. To hide their want of arms, one of these levelled his gun to shoot the Kûrd, as soon as he came within reach. Dr. Grant advised him rather to fire over his head, and this brought him to a stand. They then menaced him by signs, and, at their request, the doctor raised his umbrella, to make an impression of their consequence. The Kûrd, on this, rode back to his comrades, who moved forward to hear his report. This roused the fear's of the doctor's party to the highest pitch. Each crowded to get into the middle. Many eried They are coning, - some one thing and some another, and all would have fled, had not he strenuously opposed it, as sure to provoke pursuit. An eminence on the left, however, was too inviting, and a disorderly morement begun in that direction. Seeing their need of a leader, Dr. Grant, whose quick eye had caught another eminence, further on the road, pointed to that and bade them follow; and the next moment they were on the way again, in tolerable order. This proved the salvation of the party; for the enemy, seeing this apparently bold move, and not relishing the warm reception of their spy, moved off in another 
direction. The thought that this was only a ruse, in order to attack the prarty to better advantage while fording the river, hurried them on, and in less than an hour they were safe across.

On the last day of June it rained in the night; but, with his umbrella over his head, and his saddle-bags for a pillow, Dr. Grant slept comfortably, and was on his way again before dawn. He met Kûds again that day; but, being few, they did not renture an attack. Three years before, serenteen Armenian. were kilied on this roud, and, though diligent search was mate, no trace could be found of them or their murderers. This, and the famine, that rendered the Kûrds desperate, lent additional terror to each appearance of danger. They encamped at the Armenian village of Meirik, where is an ancient stone church, like that at Utch Kileeseh, and said to be, like it, fifteen hundred years old. The Catholicos of Aghtamar has jurisdiction over the Armenians of Kûrdistan beyond Van and Bitlis. His convent is on a little island in the lake, pleasant and fertile, but difficult of access, for want of boats. No female is allowed to enter that, or any of the convents on the other islands.

A ride of nine hours brought him to $V$ an the first day of July; and the pasha - the fourth who had occupied that post within a year - assigned him as the guest of the Armenian bishop, who occupies a pleasant suite of rooms connected with the principal church. He remained there till the morning of the 5th, treated more kindly than he was last year by his predecessor. The bishop seemed to desire the improvement of his people; and the hum of forty boys, learning to read, in another part of the premises, told that education was not entirely neglected. But this was the only school for ten thousand Armenians in the city, and forty thousand more in the province. Dr. Grant improved the opportunity to press home his obligittions, and gave the priest and vartabed some Armenian tract: as a parting gift. This led to inquiries about our missionarios; and he was happy, by the aid of the books themselves, to en- 
tradict the slanders that, even here, represented them as infidels, without prayers, religion, or a belief in the Bible itself.

As a place of residence, Van is excelled by few places in the interior. More healthy than Oroomiah, it has much of its beauty and fertility. On one side fruitful gardens, stretching for miles over the plain, and on the other the lake, surrounded by the glistening summits of the mountains, form a landscape of rare reauty. Provisions usually are abundant and cheap; and, swing to its height, it is not subject to the oppressive heat of many places in the East.

Several small villages, within three or four hours' ride, conaining together about one thousand Nestorians, form a small ommunity by themselves, and can be reached only from Van.

Col. Chesney states that Schultz copied forty-two inscriptions zear the city, one of them in the cuneiform character, and deciphered Shemiram (Semiramis) in several.

Dr. Grant spent the fourth of July with the bishop, at the monastery of the seven churches, four miles on his way to Julamerk. One of its seven chapels was destroyed by an earthquake more than two hundred years before. The rest have stood, it is said, for eight hundred years; and some cuneiform inscriptions indicate that it may have been built on former ruins. It commands a fine view of the city and lake, and is embowered in fertile gardens and vineyards, watered by mountain rills; but the climate is too cold to bring grapes to perfection.

Dr. Grant left the convent July 5, as the bell was ringing for matins, and passed over a range of hills to the valley of the Hoshab. This he forded once, and then recrossed it on a bridge at the castle of Mahmudiyeh, where he stopped during the last shower of rain he saw till the 13th of October, in Mosul. Kandi Kileeseh was said to be two hours to the east. Three hours to the south-east brought him to the Nestorian village of Seel, or Seer, about a mile from the road. They had suffered so much from Moslem depredation that, at first, they treated him with much 
reserve; but his salutation in their own language won then confidence, and he was delighted to find himself once more among friends, who knew him by reputation, though the $y$ had never seen him. They told him the story of their oppression, that had reduced a mumerons population to a mere handful; and he rejoiced in the opportunity to point them to the Friend of the poor and suffering, and then prayed with these few sheep among the wolves. Next morning, about an hour from the village, he lassed over some deep banks of snow on the summit of the mountain; then, descending a ravine, he turned from the road, over some irregular hills, to the plain of Albagh, whence Bash Kala was visible two miles to the north. As he was a day too late for the weekly cararan to Julamerk, he hired two Kûrds to conduct him to the residence of Mar Shimon. The first day all went on well, as an uncle of the emir was in the company, and the doctor slept in his tent at night; but, next day (July 8), while alone with his Kurdish attendants in the most solitary part of the road, the muleteer stopped, and demanded additional pay, and the guide, who had been sent to protect him, joined in the demand. They both refused to go further unless he gave them money on the spot. What was to be done? He had noticed them, just before, turn considerably out of the road to repeat their prayers, and he knew, from experience, that at such times they were most to be dreaded; for when they thus, as they think, wipe off old scores, they are bolder to begin anew. To accede to their demand would have been to invite them to llunder, and then kill him to conceal the crime. To resist was impossible, as they were armed, and he defenceless. But, by using a disereet firmuess, - which none could do better than he, - while, at the same time, he aroided anything that might give them a pretext for murder, he succeeded in inducing them to proceed, and, before night, was cordially welcomed by old friends in Kerme, two of whom went with him, next morning, to the residence of the Patriarch. 
This deliverance justified the confidence expressed in a letter, written just before leaving Van, in which he says, "The most toilsome and dangerous part of my journey is yet before me; hut, with my acquaintance with the people, I trust I shall pass through in safety, relying always on the strong arm of God, my defence. I cannot doubt that prayer is offered in my behalf, and I feel a sweet confidence that, whatever becomes of the weak and unworthy instrument, the eause of God among the dear Nestorians will go forward. Whether we ever meet again in this world, is more than I can say. Bearing each other in the arms of faith to a throne of grace, let us be faithful unto death, when we shall wear a erown of life."

The Patriarch was absent when he arrived, but was sent for immediately; and, to use his own words, "his welcome and umremitted attentions were all that I could ask." He had previously sent word to Tyary to have his people look out for him, and escort him safely on his way, as he had expected him to arrive from that direction. He now got ready to go with him to Jelu in person, proposing to send his brother Zadok to introduce him to such parts of the country as he had not yet visited.

The day after his arrival at the Patriarchate - July 10 - he writes to Mr. Stocking, of Oroomiah: "You will have heard that I am at length brought again to the field of my future labors and trials, - for trials here I have ever expected, and they may be very formidable. But, with my unshaken confidence that the Lord has mercy in store for this people, and, through them, for the surrounding nations, I will not be discouraged. It is the Lord's cause, and in him will I trust for its success. The Patriarch never seemed more cordial than now; but there is an unsettled aspect to the whole region, which seems to denote changes in prospect. Some of them, for a time, may seem adverse to our plans; but I feel a strong conviction that, in the end, they will be overruled for good."

These glimpses of his heart, in familiar intercourse with 
fliends, show that, though his journal is not loaded with the display of his religious feelings, yet he lived as one who felt he might not be far from the entrance of another world, dwelling in the seeret place of Him in whose presence he hoped soon to find fulness of joy forevermore.

On the same day they went about ten miles up the mountain to a summer camp, stopping for evening prayers at a chureh a mile below it. On either hand the summits were craggy and broken. Isolated eones rose up around, like so many sentinels in the evening twilight. On the highest of these stood a ruined castle, and, just below it, a chapel hewed out in the rock, where a hermit feeds the unextinguished lamp upon its altar. The mother of Suleiman Bey was there, under the care of Mar Shimon, during the absence of her son in Gawar, and showed him the same kind attention as before. Her inquiry, how he could leave his little son, and come alone to that distant land, opened afresh the fountain of tears. But little did she know of the comfort vouchsafed by the Saviour, for whose, sake he had left home and children. It was the Sabbath, and he tells us that on those mountain-tops he enjoyed, in communion with Christ, the hundred-fold that He had promised.

Early on the 12th they began to climb the steep winding path to the summit, making many a halt for breath in the long aseent. On the first summit they found shepherds pasturing their floeks, amid the verdure and flowers of early spring. Seated by a rill, fresh from the snows above, he prescribed for a few chronic complaints and diseases of the eye, - for acute sickness seldom visits so healthful an abode. Their huts were buiit of loose stones, and covered with bushes, that sereened from the sun, but eould afford no shelter from the storm. The people were overjoyed to see them, and freely opened their stores of sour curd and liquid butter, laid up in goat-skins for winter use. After a pleasant hour at this place, they continued their ascent to the glacier beyond. For some miles the mules 
made but a faint footprint on its frozen surface, and near the highent summit of the pass stood a chapel amid the everlasting snow. This lofty region could accommodate the shepherdis scarce a month in the year; but the little church might shelter the traveller when the shepherds were far away, and direct his thoughts to God. The summit had long reeeded as Alps on Alps arose, and now the rocky peak rose some hundred feet above the pass. This is the loftiest point in Kurdistan, and is about fourteen thousand feet above the sea, though some report it as high as fifteen thousand. The plain of Mesopotamia is said to be visible in a clear day. But, as the peak then wore its eap of elouds, Dr. Grint contented himself with the view from where he stood; and that extended over the mountain-tops in every direction, with no apparent limit but the power of vision. A little cloud, broken off from the mass above the peak, had floated far away in the clear sky; and, as it lay in calm repose, lighted up by the rays of the noonday sun, it seemed like a messenger from heaven serenely watching over the region assigned him by the Lord of angels. But Dr. Grant had no time to admire the grandeur of the scene; nor, situated as he was, could he make observations with the compass; and, with the rest, he prepared for the descent. He had often found this more perilous than the ascent, and especially so now, as, divested of his cloak, staff in hand, and hair sandals on his feet, he secured a foot-hold, at first, only in the slight impressions left by the feet of the mules in the firozen snow. "This passed, his progress was safer, but no less laborious, so that, at length, utterly exhausted, he was glad to ride long before any one else dared to do so; and, even then, Mar shimon inisted on his retaining the saddle, as he was accustomed to such journeys, while Dr. Grant's limbs we trembling from fatigue.

Leaving two villages on their right, they reached Zerany, the largest in the district, and spent the night in the outer court of the church, in which the Patriarch led the villagers in their 
evening prayers. Their supper of millet, boiled in milk, was eaten from a large wooden bowl, each dipping his spoonful in a dish of melted butter imbedded in the middle of it. Barley bread was laid round the edge of the goat-skin beneath. At other times, during his stay in the mountains, wheat, barley, rice, maize or rye, took the place of millet, or were used for bread; and sometimes they were made into a kind of soup. Milk is seldom used till sour, - contrary to the advice of the Patriarch Timotheus to the Tartars of Prester John, - and butter always in a liquid state.

Though the snow is here very deep, and the winters long, yet an inferior grape grows abundantly. Apples, pears, \&c., are more rare and less delicious than in New England.

Next day, at noon, when most were asleep, Dr. Grant rentured to make some entries in his journal. The villagers wondered to see him writing backwards, - that is, from left to right, - and with a quill instead of a reed. "Are you writing down all Jelu, to send to the New World?" asked Priest Zadok, as he woke from his siesta, and looked on the same operation. The doctor took the hint, and made briefer memoranda, more privately. The village priest, and several bright lads, were all animation at his mention of a school; and the Patriarch woke up when the sun shone round in his face, and, as elsewhere, expressed publicly his approval of our missionary work.

In the evening they rode to the village of Mar Ezeiya, where is one of the oldest and most renerated of their churches; it is also, perhaps, the largest. Tradition says it was built by Balak, a Christian prince of Bagdad, who used to spend his summers here fourteen centuries before. A large bell was suspended from a beam outside, and it was peculiarly affecting to the lonely missionary to hear the church-going bell echoing through those distant glens, and inviting their inhabitants to prayer. It was the hour of vespers when they came in sicht of it, and the Patriarch at once dismounted, turned his face toward 
the church, - it lay towards the east, - and went through his devotions.

There are fifteen villages in Jelû, and five more in Bass. Dr. Grant found them exceedingly desirous of a missionary. They offered to give him a house, if he would come and live among them. The habits of the men, in spending their winters abroad, render them more intelligent than the other tribes, and, therefore, more promising subjects of missionary effort. Ilis eye, too, was quick to discern that their acquaintance with the character and languages of surrounding countries would be an admirable means of diffusing truth in the places they visited, when once they themselves were filled with its spirit.

Dr. Grant here took leave of the Patriarch, who had treated him with the kindness of a brother, and now committed him to Priest Zadok, till he should leave the mountains or return to him. In the latter case, they intended to go to Oroomiah together, and then both spend the winter at Ashitha or Lezan.

A ride of four hours brought them, on the 15 th, to one of the principal villages of Bass. These lie in a valley which unites with another from Jelû, and then, winding to the south-east, passes near Ravandooz, and unites with the Zab below the country of the Nestorians. The emir had been in the habit of receiving presents from the weaker tribes, and had, just before, sent a servant to Bass to collect something in this way. Displeased with the manner of his application, they refused; and, when he resorted to force, they killed both him and his attendants. But now the villagers, who were just leaving the church, went in procession to meet their guests, and two lame children were brought to the Patriarch's brother, with their feet tien together, that they might be cured by lis cutting the strings.

The day after, Dr. Grant had some interesting intercourse with the chief men, and, after prescribing for the sick, departed for Tehoma. On the summit of the mountain, to the south-west of the village, he found some women tending their flocks. They 
brought him food, and one of them caught a sheep, from which she presented him with a fine bowl of milk. As the Jews in the days of Moses, so the Nestorians now prefer the butter of kine and the milk of sheep. "With what interest," thought the good man, "would these people read the Bible, tending their fock.; like the sweet psalmist and patriarchs of old, amid the rery scenery and customs it describes!" From the summit he rescended a ravine, two hours to the south-west; and spent the night in a hut belonging to a summer encampment, so small that he and the priest could hardly find reom to lie down in it. Next morning, while a dozen women started for their village, each hending under the burden of a goat-skin filled with butter or sour curd, he left in the opposite direction, winding down a narrow glen, that expanded here and there, so as to admit of culture. In oue of these he found a Kûrdish hamlet. Four hours' walk brought him to Gundûktha, a large village of Tehoma, where he lodged in an upper room of the church. In the evening he climbed to the church of Rabban Pitter, hoping to spend there a quiet Sabbath, in a purer atmosphere. Like two or three churches in Tyary, it has a glebe which pays one-third of its produce to the church. On Sabhath the lovely valley below was hushed in ruiet; and, while the early dawn was hailed by the birk in the trees above him, many of the villagers assembled with them for worhip. He conversed with all who called during the day, founding his remarks on such portions of Scripture as the priests, at his repuest, translated into their spoken language. Here he berame acquainted with Kasha Guwergis (Ceoroe), wext to Kasha Amaham the most learned of their ecclesiatics.

(In Monday, he went a mile further, to Tehoma Gawaia, where he translated and expounded the Bible, as before, to a much larger congregation. At first they interrupted him by their conversation, but became deeply interested as he proceed. 
ed, expressing surprise that their priests had never told them these things before.

Dr. Grant estimated the population of the six villages of Tehoma at ten thousand. But Dr. Smith set it down afterwards, from more reliable data, at five thousand, which is probably not far from the truth. The district is more pleasant and fertile than the rest, but the extensive cultivation of rice renders it subject to Revers, and it is more exposed to the Kûrds than either Tyary or Jelû. In the evening, another mile brought him to Birijai, where an arzaleh, some twelve feet high, was assigned to him and his companion. Climbing up by a rickety ladder, they found it without railing, and just large enough for both to lie down. As it was his first trial of these long-legged bedsteads, the priest was very anxious for his safety, and roused him from sleep in tying his feet to the post to prevent him from falling on the rocks below. At the doctor's earnest remonstrance, he set him free; but the idea of dangling from such a bedstead by the feet was so ridiculous, that it was long ere he again composed himself to sleep. As he lay there, he says: "I looked round on the sleeping villagers, - some at a similar elevation, and others on the pebbles of the torrent below. I thought of home, and the friends of other days. But, pilgrim as I was, and not knowing the things that would befall me, I felt a sweet assurance that $I$ was not alone; and, committing my all to the Shepherd of Israel, I was soon lulled to rest by the music of the dashing waters."

Four hours of weary walking along the ledges of the mountain side brought him to the nearest village in Tyary, on the 20th. An open war, long carried on, between Tehoma and that tribe, was brought to an end by the threatened irruption of the Bey of Ravandooz; but, though war had ceased, the old grudge still remained. He was now in the narrow but fruitful glen of Salaberka, and was hospitably entertained by Malek Berkhu. Unknown to him at the time, he now had another narrow escape. A party of Kûrds tried to intercept him on the way, 
but, finding he had passed, all turned back, save one, who had the hardihood to go and beg medicine from the very man he had intended to destroy, - nor did he beg in rain.

The only priest in the district who could read intelligently showed him a piece of an earthen vase that had been dug up near the house, and contained at substance like cinereous bones. But a more interesting discovery was made while they were talking about this; it was the colper bust of a female, with a wreath around her brow. The features were well proportioned, but, though protected from the weather in a cleft of the rock, were thickly oxidized. They at once pronounced it an idol, and each sought the privilege of stamping it under foot. The gift of a cotton handkerchief saved it from destruction; but he had to assure them he wanted it only for a curiosity, and not to worship. He said he would send it to the New World, as one of the idols of their ancestors. "No, no," was the reply ; "we are Beni Israel; therefore, our ancestors were not idolaters." Did the Ninevitish sepulchres extend so far beyond Malthaiyah and Ba. vian? In the afternoon he continued down the valley, through a succession of houses and fertile gardens; the vine hung over the wall; the fig and pomegranate grew on the terraces; but "the time of figs was not yet," and a few plums and white mulberries were the only fruit he saw. Apples, too, were given him, but they were too green for use.

On his right, a path led up to Ba Rawola. On his left, across the stream, a steep mountain ridge separated the Nestorians from the Kûrds. Priest Zadok was now so excessively fatigued that he often sat down, and at leng'th declared he would go no further. He said he was sick. Others whispered he had drunk too much wine with the Malek. Says Dr. Grant: "This was the first wine $I$ had seen in the mountains, but it did not prove the last. I was pained to find that, though not so plenty as on the plain, yet the clergy made too free with it, and when 
I expostulated justified themselves on the ground that they di: no injury, but were only more pleasant, under its influence."

At sunset they stopped near a cluster of houses, where the people were very kind. They slept on hurdles laid on the smooth stones of the stream, and the best of them were given up to their guests. These slept all the sounder for their fatigue, and rose with the sun to a yet more painful walk, by which ir. Grant was quite exhausted before night. At a mountain hamlet, where they stopped to rest, the village priest kindly sat down and rubbed his limbs, remarking that he was not learned in climbing their rocks. Priest Zadok complained bitterly, and said nothing would induce him to endure the heat and fatigne, but regard to the doctor and the cause in which he labored. Dr. Grant adds: "It was the cause of Christ, and I felt lumbled by my umworthiness to suffer for his sake." Before night they reached Lezan, the first village he entered in the mountains two years before, and he at once found himself among old friends; but, owing to his Frank dress, he was searcely recognized.

It was late next morning before the sun looked over the mountains on his bed by the Zab, and he set out at once to Ashitha, in search of a purer atmosphere. But he was so beset on all sides for medicine that it was afternoon ere he finally left the rillage. The Malek, absent on his former visit, insisted now on his stopping under his roof; and even made him an offer of a house to live in, if he would remain. Passing through Minyanish, the residence of the young man whose restoration to sight had secured his favorable reception at the first, he was cheered to meet him again, with another present of honey for his benefactor. Says Dr. Grant: "Such cases encourage the missionary to endure hardness as a good soldier of Jesus Christ. But I cannot speak of trials, while an open door is given me to speak to the people with all fidelity."

He was welcomed to the house of Kasha Auraham, in Ashi- 
tha, about noon on the 23l, whom he found at his usual employment. Here he remained for nearly a month, spending the days in intercourse with the people, and the nights on the roof, where he also dined, and had his evening meetings. On the Sabbath, forty or fifty assembled, to listen to such expositions of scripture as seemed adapted to their case; "for," says he, very modestly, " it was the only kind of instuction for which I felt qualified. Nerer was I more impressed with their perishing condition. With few exceptions, even the elergy are exceedingly ignorant; and how can they enlighten others? All need to be taught the first principles of the oracles of God. But, if their ignorance is affecting, their docility is exceedingly encouraging. Eren the priests frankly confessed that they were blind leaders of the blind. Their consciences responded when their sins were set hefore them, especially when I urged that their departure from God was the occasion of their troubles from the Kûrds, which they feared would soon be greater. I showed that God had chastised them through their enemies, thus far, gently; but I feared that he would do it more severely, even to the loss of their independence, unless they repented. They confessed it was even so, for a score of men from the village had already fallen, - others were in eaptivity. More than seven thousand of their sheep had been driven away, and now the locusts had come up in swarms to snatch their bread from their very mouths.

"Some regarded me as a spy of the Turks, and others as in the employ of the emir. But I endearored, by well-doing, to secure their confidence, since, under God, it was our only protection in the prospect of political commotion. And, as the sick recovered under my hands, confidence was restored. Their returning health testificd to the benevolence of my mission, and the report was wafted on every breeze." In one day he remored cataracts from the eyes of no less than seven persons, most of whom were benefited by the operation. Some were from a distance, and thus he had an opportunity to speak to all of Christ 
and his salvation. Two young men were brought to him dan.gerously wounded, and senseless, - one by falling down a precipice, the other by the stroke of a stone, started by his sheep above him on the mountain side, - but both recovered, to the surprise of their delighted friends.

Ashitha is the largest and one of the most healthy of their villages. But it is not central. The winters are severe, and fuel is scarce. The summer, however, is delightful, and snow remains, through the whole of it, within half an hour's walk. The gardens and poplars, interspersed with walnut and other trees, give a pleasing aspect to the valley. The grape is cultivated, but few fruits come to perfection. Insects are not so annoying as elsewhere. The people are active, but rougher and more rude than in other places. Yet all desired Dr. Grant to resile among them, though he observed, with pain, that temporal benefits were a more prominent reason for it, in their minds, than spiritual.

Priest Zadok and other's often broke their weekly fast, but all observed the great fast before Fuster with much strictness. The brother of the Patriarch defended Dr. Grant's non-observance of such things, on the ground that he was not bound by the councils that had imposed the burden on them.

The last Sabbath he spent in Ashitha, the village met to consult on an invasion of Berwer, where two Nestorians had recently been murdered. Some of the more aged advised forbearance. But Zadok and Priest Abraham cried, "To arms!" at once. The former said, they were not men, but women, if they submitted to such insults. The latter offered to lead them at once to battle. "What!" said Dr. Grant, "on the Sabbath ?" "We will fight," said the other, "in the night, after the Subbath, but must set out now, ere the people disperse." Dr. Grant replied that he could not interfere in a question of war or peace, but asked them whether they could hope for the blessing of God on the desecration of his holy day, and whether they 
had not better spend it in prayer for his guidance. They sepa rited, after a spirited discussion, in which he took no further part, and the invasion was postponed; - though, after he left the mountains, several rillages united together to attack the Kûrds, and dirove off some thousands of sheep, in retaliation for their previous loses.

Dir. Grant had sent a messenger to Mosul to learn whether lis associates had arrived; and, after waiting a week beyond the time set for his return, went to Minyanish on the 16th of lugust. Next morning brought the sad news of the death of Mr. and Mrs. Mitchell, and the sickness of the survirors. He stalted at once for Lezan, intending to fly to their relief via Anaria ; but the chief of Berwer, afraid of his infinence at Mosul in behalf of the Nestorians, had giren orders not to suffer him to miss. He spent the 1,th in getting realy to leave, and giving yarting counsels to the people. At this juncture the Patriarch cummoned the Nestorians to arms against a combined force of Kûrds and Turks from the north, and his brother was now anxious to detain him as a councelloi ; but this only strengthened his purpose to depart.

On the 19th he thus wrote to Dr. Wright: "In the removal of Mr. and Mrs. Mitchell we are armonined that the Lord would try, as by fire, those who may enter this part of the field. Truly, most trying must be the situation of dear Mr. and Mrs. Hinsdale, so bereared, and both mon a sick bel. I shall spare no effort to reach them as soon as possible. Although the way is not free from danger, yet their situation calls me to meet whaterer perils may exist. Weae it not for their need of me, I should be tempted to come to Oroomiah; for to remain with the Patriarch might be to enlist as a militury surgeon, an honor to which I do not aspire.

"The situation of the Nestorians is likely to become a trying" one, if the Turks, as is probable, unite with the Kurds against them. They should not be forgotten in our prayers. I feel the 
most consoling confidence that the Lord will overule all for good, and his kingdom speedily be built up. How delightful it will be to hear the songs of praise, the offerings of pure hearts, echoing through these vales, till

- The mountain-tops shall catch the flowing joy, And one glad song each heart and tongue employ'!

"I do not think any temporary distubance here ought to deter others from joining us. By the time they acquire the language, they will, I doubt not, find enough to do. There is a wide and interesting field for preaching now; and the trials through which this people are likely to pass may incline them more readily to turn to the Lord. I tell them it is their sins that provoke these chastisements, and they are ready to confess that it is even so. I hope I may have been the means of calling some attention to this point, and the leaven may spread after I am gone. The Lord in merey watch over this dear people, and bless us all !"

It may give some idea of the difficulty of communication in the momtains to state that this letter, written in Lezan, August 19, 1841, was not received in Oroomiah till April 10, 1842. At the same time he sent a note, written in pencil, to Mr. Stocking, in which he says, "I have nothing to add further than to commend you all, and myself, once more to our corenant God. Our bereavement maly seriously affect our plans; but the cause is Gol's, and he will take care of it. In him is my hope, and I feel sure my confilence is not misplaced. You will not forget us in your prayess."

That very day, Priest Zadok procured ten men to escort hin, by night, across the distict of Berwer. He writes: "The sun was sinking behind the mountains as I bade the people farewell, and I rode on silent and sad, till roused by my eompanions saying, as they pointed to the valley behind us, "Is it not beautiful?' It was tinged with the sombre hues of twilight, and 
was in such harmony with my feelings that I could scarce refrain from tears. My thoughts were full of the past, present and future, of this beloved people. As we climbed the mountain, the stars shone out as they shine only in the Kast, and we seeme l toiling to reach their shining orbs. The ascent became more difficult, till I was obliged to walk, and then draw myself up by taking hold of the projections of the rocks. My giard, now, after whispering together, refused to go on unless I doubled their reward. I told them I was entirely in their power, - they were ten, and I alone, - and, if they thought fit to rob and kill me, I should make no resistance; but I would not accede to their demands. If they went on as they had agreed, their present, at the end of the journey, would be proportioned to their good behavior; but, if that did not suit them, they might return to their village."

Who does not admire this far-seeing conduct of the lonely missionary, boldly facing personal danger rather than afford a precedent for similar extortion in the future? He knew the character of the people, whom he loved for Jesus' sake; and, though he might yield somewhat to Kurds at a distance, yet he would not purchase his own safety by exposing his associates to the like treatment, in time to come, from the Nestorians themselves. Awed by his calm firmness, his escort declared themselves ready to serre him at the peril of their lives; and refused to receive the customary present, at the end of the journey, unless he should give it of his own free-will. Before reaching the summit, one gave out, exhausted, and they left him with some shepherds on the mountain; soon another followed his example, leaving only eight for the rest of the way.

The most toilsome part of the road was now past; next came the dangerous. He dared not pass through the Nestorian villages of Berwer, lest the chief should punish them for letting him pass. They now moved in single file, with the utmost silence, halting occasionally, and reconnoitring, to see that they were 
not observed. The fires of the shepherds enathlut them to avoid their camps ; but two Kurdish rillages lay directly in the road, and they had to pass them with great caution. Taking a circuit round, they passed the first in safoty. At the next a castlo orerlooked the road, and the watch-cry of the sentinels was audiblo long before they reached it. But his guiltis knew every pass; and, in breathless silence, they led him through a ravine, where he heard the watch-cry close on the right, and soon after behind him. The prospect now brightened, though the danger was not yet past. To cross the creek by the usual bridge was not deemed prudent, and, with difficulty, they forded it below. On emerging from the thickets on the other side, some of the party were missing. They neither dared to call aloud nor separate in search of them; but soon all met again, and moved on, slowly and cautiously, as before. They often felt the want of moonlight, and yet rejoiced there was none; for in darkness was their safety. Dr. Grant felt the hands of his watch: it was one o'clock. "Time enough, but none to spare," whispered the guides; and on they wandered, through thorns and over roeks. Having regained the path, they ate a morsel of bread, drank at a running stream, and hastened forwarl. Samrise found them on the mountain-summit, some three miles from Amadia. The Nestorians dared not go further, but kissed his hand at parting, and of their own accord offerel to remain where they were, and allow no Kûrds to approach from that quarter till he was safe in town. 'They then passer the day concealed among the rocks, and retraced their steps in safety on the following night.

With his baggage on the back of the Kûrd who had brought the letter from Mosul, Di. Grant deseenlel toward the town. Half-way down, two armed Funds sarted fiom hehind a rock, and attempted to secure the baggage. Both Dr. Cirment and his attendant were unarmed; and at long dispute in Kûrdish ensucd, of whick Dr. Grant conld only understand the simn to deliver up his effects. At length, on pointing towart the place where the 
Nestorians were concealed (they were hidden by the inequality of the ground), he was suffered to proceed, and soon entered the gate of the fortress with a grateful heart. The governor remembered his former visit, and treated him with much kindness; but he left the same afternoon, and next day reached the Jewish village of Gunduk, where he spent the sabbath.

On the 24th he breakfasted in the large Yezidee village of Hattara, ravaged by the Ravandooz chief seven years before. He found it now in great fear from the Arabs, who had overrun the region, and were now approaching the place. Terrified for themselves, the villagers could spare no guard for him. But he would not turn back so near. Mosul; and, finding three soldiers on their way there, he went on in their eompany. By making a detour they aroided the Arabs, who had taken the villages on the direct road. At one time a cloud of dust led them to fear they had fallen into their hands; but it proved only some fellahin (peasants) fleeing with their flocks; and he rode into Mosul on a horse lent him by the head man of a village, in return for his prescriptions. Arrived there, he writes: "It seems as if the good hand of the Lord had been with me all the way; for, had I been later, or pursued a different route, I had not been able to enter the mountains this year. He gave me favor with the Patriarch and people, then led me out of the mountains just as they hecame the theatre of war, and now brings me to the resene of my surviving associate, when, owing to a langerous relapse, he seemed about to follow his companion to the grave." 


\section{H A P T E R X I.}

JOURNEY OF MESSRS. HINSDALE AND MITCHELL-DIARBEKR-LETTER OF IIR. MITCHELL - IIIS SICKNESS AND DEATH - SICKNESS OF MRS. MITCHFLL - ARAB INHUMANITY - HER DEATH - SICKNESS OF MR. AND MRS. HINSDALE - IEAT OF NOSUL - JACOBITES - MISSIONARY PROVIDENCE JEWS - NOHANMED PASHA - TURKISH OPPRESSION - LETTERS OF MONS. BOTTA - TOUR AMONG MOUNTAIS NEAR MOSUL - MICHA - ATHANASIUS, BISHOP OF MALABAR.

Ix order to preserve the narrative of Dr. Grant unbroken, nothing has yet been said of the journey of Messrs. Hinsdale and Mitchell. Let us now turn our attention for a moment to them. We have already seen them sail from Boston, January 18 th. A rough passage of forty-one days brought them to Smyrna, where they embarked immediately in an Austrian steamer, for Beirût, reaching that port on the 12th of March. Here they were detained, fiom various causes, till April 24 th, when, with the Rer. Mr. Beadle and wife, they sailed in an Austrian merchantman for Lsanderun. Though the voyage is often performed in a day, contrary winds protracted theirs till the $30 \mathrm{th}$. On the 4th of May, they left Iscanderun, by way of Antioch, for Aleppo, and arrived there on the 8th. Here Mr. Beadle remained to commence a new station, leaving them to go on to Mosul alone.

A caravan had just left for that place before their arrival, and no other would start for some time to come. Another interpreter too was to be obtained, in place of $\mathrm{Mr}$. Beadle, who had hitherto acted in that capacity; and, after a long search, they secured the company of Mr. Kotschy, a German naturalist, who, 
to a good knowledge of merlicinc, anded the experience of seven years' journeying in Africa and western Asia. After all else was ready, Mr. Mitchell was seized with intermittent fever, and this detained them a week longer, so that they did not leave till the 2 th. This was perilously late in the season for such a jotirney. Still, had they pressed on with the usual speed, all might have been well. But, unhappily, green grass was abun. dant, and the muleteers loitered along as suited their own conve. nience; and, once on the roarl, the company were entirely at their mercy. Still, the journey was both pleasant and prosperous, as fir as Diarbekr, which they reached on the 12 th of June.

On the 14th, Mr. Mitchell wrote to Mr. Beadle, making grateful mention of the goodness of God up to that time, and giving a pleasut description of their encampment, in a grove of willows, by two streams of pure water, an hour north-west of the city. He mentions ice as so plenty in the bazaar that two cents procured as much as a man could cary ; and describes the company as not only in better health than when they left Alepro, but also refreshed by rest for the fatigues yet before them. Speaking of these as though with a presentiment of what was before him, he says: "What the result will be remains to he told. It is pleasant to refiect that God will order all things concerning us in infinite wisdom and benevolence; and I trust we whall all he willing to abide by the allotments of his Providence. Ih our difficulties and dangers, I love to see God on the throne, doing all things after the connsel of his oun will; and, whatever be the resnlt respecting us, the will not allowe the interests of his glorions limgdom to suffer by our trials."

Conkl his feeling have heen more appropriate to his situation, hat he known all that was before him? He knows not; but God, who orders the steps of the good man, is preparing him for what He sees awaiting him. Is there one of the redeemed, who looks back on what we call his sudden departure, who doss 
not find everything made ready for it by his covenant God as he could never have prepared it himself?"

Diarbekr was the birth-place of the mother of Mar Ephraim. Its lava walls, built by the Emperor Constintius, have seventytwo towers; and its large church, now a mosque, was founded at first by order of Heraclius, 629 A. D., and then, after being burned, rebuilt again in 848. In 869, in the short space of three months, the city is said to have lost thirty-five thousand inhabitants by the plague. Its population now is said to amount to eight thousand houses, fifteen hundred Armenian and sixtythree hundred Mohammedans. It is the ancient Amila, anrl, according to Pococke, the Dorbeta of Pliny, though others affirm it is the Tigranocerta of Lucullus. The Turks call it Kara Amid.

The missionaries left on the 14 th, and reached Mardin in five days. While Mr. Hinsdale and Mr. Kotschy went up to the town to make some provision for the rest of the journey, Mr. Nitchell kept on with the caravan to the village of Golek, on the plain below. Here a violent rain-storm came up; and, in his efforts to keep the tent from being blown down, he was thoroughly wet and chilled. On the next day (Sabbath) the ague returned, and again on Monday, though with less violence than before. This was the last attack of that disease, and after it he felt well and ate heartily.

On Monday, the 23:, they rode seven hour's to Haznaûr, and Mr. Mitchell, though he spoke of feeling unwell, secmed cheerfirl, and had a refreshing sleep in the afternoon. Next day, starting at a quarter before three A. ... they rode the same distanee, to Chulagha. He complained of the oppressive heat. and seemed quite fatigned during the latter part of the ride, but nots much more than the rest. They had designed going by Sinjar; but, as one stage on that route would keep them in the saddle nearly twen'y hours, they resolved to go round by Jezira.

On Wednesday they rested till evening. Mr. Mitchell went 
out during a sirocco, in the afternoon, and eame back complaining that he could not see distinctly. An emetic relieved him somewhat, and in the evening he was so anxious to go on, that they started at seven P. I., and rode six hours. He seemed much refreshed by the ride, and retired with the rest. But, in the morning, Mr. Hinsdale found him ready dressed for the journey, and evidently deranged. Finding the water they had stopped at in the dark a mere pool, and unfit for use, they were compelled to remove an hour further on, to the village of Mushtafia, a man walking on each side of Mr. Mitchell to support him in the saddle. A servant, sent on before, had secured the best room in the village; and in that he was laid, but evidently fast sinking. Mr. Kotsehy bled him, but partial success was secured only by rubbing and washing the arm. Other remedies proved equally vaiu. His feet were cold, and a clammy sweat covered his whole body. He seemed much troubled at some great obstacle lefeating all his efforts to do goor at the very moment of suceess; and thus he sank, like a flower withering in the sun, till, near two o'clock on Sabbath morning, June 27th, he ceased to breathe. No struggle indicated the moment he exchanged that Arab hut for a mansion above. The stricken survivors could hardly believe that he was gone. The stroke was so sudden, it seemed a dream. But it was too true; and, in the stillness of that Sabbath morning, they felt as if standing on the borders of another world, amid the silent movements of invisible spirits, ministering to the heirs of salvation. They were recalled to the sadness of their situation by the Kundish villagers refusing to allow the Christian to be buried in their grave-yard; and they resolved to carry the remains seven or eight miles, to a .Jacobite village.

The villagers would not touch the body, lest they should be polluted. The survivors were too exhausted to earry it themselves. So, fastening it on a horse as best they might, the sad procession noved to Telabel, about five hours from Jezira. 
Here a grave was dug in the village cemetery. Green branches were strewed on the bottom, flat stones were set on their edges roml about, and the body was laid between them; for coffin there was not in all the region. Other flat stones were laid above it. Straw was thrown in to fill $u_{p}$ the crevices, and the earth was replaced over all. Mr. Hinstale commended the bereaved one to the wilow's God, praying that He who appointed the trial would strengthen her to bear it, and Himself be to her the God of all consolation. Two rude stones were set up to mark the spot, and the sorrowing band returned to their desolate room at Mushtafia.

Mr's. Mitchell seemed wonderfully sustained in that hour of trial; but next morning, when other hands assisted her on horse-back, grief could no longer be restrained. Who can fathom its anguish, far from the friends that would have loved to comfort, and with none to look forrard to in that unknown home, among strangers? None but He of whom it is written "In all their affliction He is afflicted;" and He was with her.

Eight and a lalf hours brought them in sight of the Tigris, at Beshabor. The next day was spent in crossing on rafts supported by inflated goat-skins; and on the 30th they rode six and a half hours, to Amelka, a Yezidee village. Next morning Mrs. Mitchell was so ill, they had to stop, after only one hour's ride, at Bowerea. There, for four days, she lay in one of its mud-hovels among Arabs so rude they could not be kept out of the sick-room; and in it laid hands on whatever they fancied, before the very eyes of those who could not resist them. Even the women ent off the hooks-and-eyes from the dress of Mrs. Hinsdale, while busy with her suffering companion. As anything seemed preferable to such quarters, they left on the evening of the th, Mr. Hinsdale having had to send to a distant village, ere he could find men willing, for any price, to carry the litter he had prepared for Mrs. Mitchell; and often after, she had to be laid in the road, while he rode far and near to 
find four men willing to perform what they deemed the degrading service of carrying a woman. It was now so hot they were obliged to travel by night; and as, during the day, Mrs. Hinsdale was much occupied with her sick associate, she was often so drowsy on horseback that her husband had to walk hy her side, to prevent her falling. Three years afterwards, she pointed out to the writer a place in the road where, wrapped in her cloak, on the ground, she snatched half an hour's sleep, at miclnight, amid Arabs clamoring for money, and yet unwilling to earn it by carrying Mrs. Mitchell.

Soon after sunrise, on the 7 th, they came in sight of Mosul; and never did wanderer so hail the sight of home as they did that city of strangers. They were cordially welcomed by Mr. and Mrs. Rassam, one of whose servints, sent to meet them, had rendered them essential service the last two days of their journey.

For a day or two Mrs. Mitchell seemed to improve, and at the same time have unusual enjoyment in Christ; but soon her disease assumed a new form, and from that time till her death, on the 12th, reason was dethroned. For two days before her death Mr. and Mrs. Hinsdale were unable to see her. Nor were they able to perform the last offices for her after death. Strangers prepared her body for the grave, and followed it to its last resting-place. But He who eame, and, as we trust, received her spirit to himseif, was no stranger to the redeemed one he ushered into bliss. Let us not say that severed family was reünited, but rather that they entered into the presence of Him they loved more than one another; that each was received into that one family above, of which earthly ones are but the shadow.

Mr. Hinsdale, who had watehed with Mrs. Mitehell till he fainted in attempting to walk from one room to another, was taken violently ill before her death, and was not able to leave - his bed till August. Mrs. Hinsdale, at the same time, was too 
ill to render him any assistance. And, as we have seen, Dr. Grant arrived just in time to save him from the probably fatal consequence of a relapse.

In view of these afflictions, Mr. Hinsdale remarks: "And now what shall we say? Only that 'It is the Lord. Let him do what seemeth him good.' We know that the cause is far dearer to Him than it can be to us. I have feared lest the churches should be so disconraged by these apparent frowns of Providence as not to send more laborers into this field. But what are these sacrifices made by the church to that the Son of God made for the salvation of the world? May they only call forth more earnest prayer for our success!"

That these fatal results were not owing to any peculiar hazard in the journey itself, but only to the lateness of the season when it was performed, is, perhaps, sufficiently evident from what has been said. But it will be yet more manifest when we see Dr. Smith passing over the same ground in March, 1844, not only without injury, but with his health actually improved by the journey.

The climate of Mosul is very hot, as will appear from the following abstract of the temperature for a single year.

Average.

\begin{tabular}{|c|c|c|c|c|c|c|}
\hline & Sunrise. & 2 P.M. & Sunset. & Lowest. & Highest. & Gen. Average. \\
\hline Jinu:ıy, & 38 & $\frac{47}{17}$ & 46 & 30 & 55 & 43.67 \\
\hline February, & 44 & 55 & 51 & 35 & 63 & 50 \\
\hline March, & 51 & 62 & 58 & 45 & 69 & 57 \\
\hline April, & 50 & 62 & $\begin{array}{c}57 \\
9 \text { P.M. }\end{array}$ & 38 & 75 & 56.33 \\
\hline May, & 66 & 82 & 74 & 58 & 91 & 74 \\
\hline June, & 76 & 96 & 88 & 65 & 104 & 86.67 \\
\hline July, & 86 & 106 & $\begin{array}{l}\$ 5 \\
\text { Sunset. }\end{array}$ & 78 & 114 & 95.67 \\
\hline August, & 81.03 & 98 & 93 & 74 & 105 & 90.64 \\
\hline September, & 71.71 & 87.69 & 83.55 & 68 & 93 & 80.98 \\
\hline October, & 65.3 & 78.65 & 74.71 & 56 & 87 & 72.89 \\
\hline November, & 56.43 & 62.5 & 59.4 & 48 & 79 & 59.44 \\
\hline December, & 42.45 & 49.86 & 47 & 30 & 59 & 46.27 \\
\hline
\end{tabular}

Giving for the year the average of 67.80 . Coldest 30 , warm- 
est 114, range 83. This was in 1843-1; but recent intelligence from thence $(1852)$ speaks of the mercury as high as 117 . This may seem an excessive heat for latitude north 36.19 ; but it may be relied on as correct. Three thermometers were htung up in different places, for several days, to determine the most eligible position; and, when removed into the sun at noon, the mercury rose at once to $14 t$ or 146 . On accomut of this excessive heat, all who are able have serdaubs (cellars) fitted up under the court of the house, for sitting-rooms in summer; and the nights are spent on the roofs by all classes, from Miay till September, - dew or rain, during the warm season, being alike unknown. Siroccos sometimes occur in the summer; and then the air is so filled with fine sand, that, however one shuts himself up, it is deposited all around him, and sifts into every drawer. desk and trunk. The stifling heat in the innermost apartment produces the same lassitude as without; and the rery air seems lurid and dark, as if almost impervious to light. In July, every dry objert communicates the sensation of heat. Beds seem just scorched with a warming-pan, and eren the stone floor is hot to the touch. A change of linen, instead of impart. ing the cooling sensation that it does in other climes, feels as if fiesh from the mouth of a furnace; for perspiration keeps the body cooler than the dry substances around it. Such extreme heat deals most unmercifully with furniture. Solid mahogany desks are split; articles fastened with glue fall to pieces; miniatures painted on ivory curl like a sharing, and the irory landles of knives and forks crack from end to end. An unfortumate piano, that had wandered from England to one of the consulates, was continually wrenched out of tune, and rendered useless. Such was the climate in which Mrs. Mitchell suffered her last sickness; and Mr. and Mrs. Hinsdale recovered as this excessive heat began to moderate.

Dr. Grant and his associates now found themselves in peculiar circumstances. They were sent to the Mountain Nestorians; 
but the way, to them, was now hedged up. The Kûrds were attacking their more exposed pasture-grounds. Turkey was assuming a hostile attitude. The emir had invoked its aid, and the danger was that both together would overwhelm them. The Nestorians themselves, split up into hostile parties, were incapable of any concerted movement. Suleiman Bey had sided with many of his tribe who were opposed to alliance with Turkey, and seized the reins of government in the absence of his cousin; and, as the main object of the Osmanlies was to subjugate the Nestorians, as well as the Kûrds, the Patriarch naturally, but unhappily, as it proved, sided with his friend. In such a state of things it was vain to attempt any missionary labor.

But, though shut out from that field, they found themselves in another. Without any plan of theirs, God had placed them in a city of thirty thousand inhabitants, of whom nearly onethird were nominal Christians. From the Black Sea to the Indian Ocean, and from Aleppo to the plains of Aderbijan, there was not one evangelical missionary, of any denomination whatsoever. The whole region seemed abandoned to Papal superstition and Moslem fanaticism. In such circumstances, their hearts could not but be stirred within them. But the wide extent of the field formed by no means its greatest claim. Another branch of the venerable church of Antioch, that had long withstood the assanlts of Rome, was now attacked from a new point. By her usual arts Rome had seduced a portion of the people; and, true to her persecuting character, she now invoked the aid of the Turks to take away the churches from those who still remained true to their ancient faith. "On the side of their oppressors there was power," and soon rough partition-walls divided the sanctuaries of their fathers. On one side the faithful remnant chanted their ancient hymns; on the other rose the voices of the Papists, amid wax images imported from Rome.

In such circumstances, it was natural that the Jacobites, - for that is the curch referred to, - as soon as they learned the 
adherenee of the missionaries to the Bible, and their opposition to Papal innovations, should regard them as friends. Painfully sensible of the need of knowledge in order to resist error, they had already, in their poverty, established schools; and now they welcomed the missionaries as valuable assistants in the work. Still. as they had once been duped by the plausible pretences of the Papists, they were eautious in their advances toward strangers. But Providence had provided for this also. When Dr. Grant arrived in Mosul, he found Joseph Matthew, a Jacobite priest, from Malabar, - a graduate of the English college at Cottayam, and very evangelical in his views, - on his way to the Patriarch at Mardin, to be ordained metropolitan of the Jacobites in India. He spoke English with much propriety, and manifested a deep interest in the spiritual welfare of his church. He at once gave the missionaries the right hand of fellowship, and did all in his power to recommend them to the people. But then, though with the former he could converse in English, he had no medium of intercourse with the latter. And this opens another page of missionary providence.

A young Jacobite millwright had grown up to manhood without knowing a letter. Such a thing as an adult learning to read was, to him at least, unheard of, and by the people about him deemed impossible; so that, when he made the attempt, he was laughed at for his pains. Undismayed by ridicule. he induced the son of a priest to teach him the Syriac alphabet: and, after he came home from his day's work among the rude horse-mills of the eity, by the light of his lamp, in the solitude of his own room, he spelled his way into a tolerable knowledge of the ancient Syriac. Not content with merely repeating the sounds of the words as others did, he sought for their meaning; and, mark the result! The priest from India spoke this language freely, and, with Micha for his interpreter, he preached Christ and him crueified to the Jacobites of Mosul. What a chain of providences! Just when that church, hard pressed 
ly its cnemies, was looking round for help, the missionaries were sent; and while they were held back from entering the field they came from America to occupy, a priest, from India, prepared to appreciate their object, was sent to introduce them into another; and, from among that other people, in an unusual way, God provided an interpreter for his servant from the East. Such things reveal the deep interest of the Redeemer in the missionary work, and the manifold agencies he can make to coöperate in its prosecution. August and September were filled with the labors of this new coadjutor; and by these, and other labors of the mission, especially the circulation of the Scriptures, a spirit of inquiry was awakened, that never wholly subsided, and even now promises abundant fruit.

A Chaldean priest, who was awakened to many of the errors of his church, also tendered his services, and was employed for some months as teacher in Syriac.

The efforts of England to ameliorate the condition of the Jews in Turkey had led the two hundred families of that people in Mosul to feel that Christians were their friends; and many of their leading men called on the missionaries, and conversed fieely respecting the Messiahship of Christ.

Both Dr. Grant and Mr. Hinsdale were invited to their synagogue at the Feast of Tabernacles, and were ushered into the tabernacle erected in the court. Besides the chief Rabbi of Mosul, another from Jerusalem, and a learned Jew from Kerkook, were present. Deut. 28:9 and 15, suspended on cards in a conspicuous place, furnished admirable themes for practical remarks. It seemed as if they had placed before them the righteous cause of their distresses, and the way of deliverance. They conld not deny the former; but they excused themselves from following the latter, on the ground that, even if they should, others would not, and, therefore, the curse would still remain. It was interesting to recognize, in the Bible they used, one given by $\mathrm{Dr}$. Grant to a Jew in Oroomiah several years before. 
He now furnished them with a good supply; and many read the New Testament both in Hebrew and Arabic.

At the end of September Priest Natthew and his interpreter .eft for Mardin, where we will leave them, for the present, in the patriarchal convent Deir Kafran, a place to which the reader has been already introduced.

In the beginning of October, Dr. Grant, with Mr. Rassam, tha English vice-consul, visited the pasha at Hammam Ali, trielve miles below Mosul, and not far from Nimrûd, on the opposite side of the river. The hot sulphur springs here are much re. sorted to in summer; and there are also springs of petroleum. The pasha told him that an army of Turks and Kûrds, from Van, Jezira and Hakkary, had subdued the Nestorians, and burner? the house of the Patriarch. The last was true; but the other proved to be only the invasion of a single tribe.

As we shall have more to do with this man, let us glance briefly at his character and conduct. Nohammed Pashaknown also by the sobriquet Injel Bairakdar (The Little Ensign) - rose, by the force of his own character, from even a lower station than that - if report speaks true - to the rank he then held; for it is said he commenced life as a groom. Be that as it may, his decision and energy were so well known, that when, for some time, each pasha sent from the Porte had been assassinated by the Mosulians, he was selected as the only man adequate to the post. He found the whole city distracted by sedition, trade at an end, and every house a fortification, from which the followers of each petty noble shot at the partisans of all the rest. Instead of taking up his quarters, like his predecessors, at the palaee within the eity, he took possession of an old country-seat on the plain to the south. Strongly posted there, he defied every attempt at assassination, while, one by one, the leaders fell by his secret agents. This done, he disarmed the eity, - punishing severely all who refused to surrender their weapons. At the same time he put hundreds of the leading 
men to death, and confiscated their property. This energy and rapacity ran side by side through his whole course. We have seen the rebellion at Mardin, in 1889, quelled by him at once, after the Pasha of Diarbekr had attempted it in vain. Again, the Kûrds near Mosul rebelled under his extortions, and that insurrection was put down, mercilessly but effectually. Some of his miserable prisoners were impaled alive, elose by the bridge where their fellow-clansmen daily entered the city, - giving them significant warning what to expect, should they again incur his rengeance.

The Arabs who invaded the pashalic during his absence elsewhere, and put Dr. Grant in such peril on his return from the rountains, were also chastised; and the Yezidees of the Sinjar, accustomed to robbery from time immemorial, were signally punished. Their villages were laid waste, their flocks driven away, many of their men slain, and more made prisoners. Throughout the province all was quiet. The Arab dared not venture within reach of so active a foe; the Kûrd and the Yezidee no longer plundered. But, though secure from all else, men soon learned to dread their deliverer more than the robbers from whom he saved them. Each village and hamlet was taxed to the uttermost, till many were rendered as desolate by the tax-gatherer as they ever had been by banditti. Whole villages fled from an oppression they could not endure. But even flight was punished so severely, that the miserable victims learned to flee singly, and at night, as their only chance of escape. Erery" where, in the plains round Mosul, in the valleys of Kurdistan, or among the hills of Mesopotania, were roofless houses and d:serted fiehts; lleserted because it was easier to begin anew elsewhere than to sow and reap for the pasha.

At Mosul he built large barracks, and established a cannon foundery, where brass pieces, of various sizes, were cast, and mounted ready for use. Some were intended to be earried on the backs of camels; and some field-pieces were not only pro 
vided with very good carriages, but harness was manufactured, and horses trained to the service. T'ents, and all kinds of military equipage, even hard bread enough for a long campaign, were all ready for the fich at a moment's notice. A well- appointed military band, with European instruments and music, played martial airs every evening in front of the palace.

But the place where Di. Crant now found him affords an illustration of the mamner in which he met this expenditure. To make his powder - for he had converted a large mosque by the river side into a powder-mill - he wrought a sulphur-mine near this very spot. As it produced much more than he could use, he exported it to Bagdad; but that market was soon overstocked. He next apportioned the amount on hand among the various sects in Mosul; and, whether they needed it or no, willing or unwilling, each man had to buy so much sulphur at double the market price.

Whenever any district was drained of money, - no uncommon occurrence, - the taxes were received in kind, and whatever was not needed for the soldiery was disposed of in the same manner as the sulphur. On his return from his Sinjar campaign, the flocks of the conquered Yezidees were disposed of by the same method; and where the animal, over-driven in the heat, had perished on the road, or, mayhap, been eaten by the soldiers, its ears, cut off and brought to the eity, had to be paid for, just as if it had been delivered alive and sound.

Another mode of replenishing his exchequer was to forbid all pursuing a given trade, except those to whom he sold a monopoly at an exorbitant price. A respectable Moslem, who had the monopoly of coffee, came one day to visit Dr. Grant. The doetor inquired how much he paid for it. So and so, he replied; aml, "take my whole sales, I do not receive the same sum in return." - " How, then, do you live?" — " O, last year I had the monopoly of making rafts, and prospered; the pasha heard that I did, and this is the result." It may interest some to know 
the amount of his exactions for this year (1841). It was no less than three million one hundred and ninety-five thousand five hundred piastres, which, at twenty-three piastres to the dollar, is about one hundred and thirty-eight thousand nine hundred ani thirty-five dollars. Some of the items are as follows: Tax 0.3 lads entering the gates, three hundred thousand piastres; monol. o'y of soap, three hundred and fifty thousand; building raft: fif! y thousand; tobacco, twenty-four thousand five hundred; cofter, twenty-seven thousand; duty on grain, one hundred thousan?; on meat, one hundred and twenty thousand; stamp on goods, two hundred and seventy-five thousand; dying with indigo, two hundred and twenty-four thousand; corporation-tax, one million and fifty thousand; exactions from Hoslems at the New Year, sixty thousand. Besides these, for the Kharaj (tribute demanded by Moslem governments from Christians and Jews), fixed by the Sultan at one hundred and ten thousand piastres, he levies two hundred thousand.

After such statements, no one need be surprised to know that. while, in 1835, the imports of European goods amounted to nine hundred and sixty-six bales, in 1841 they amounted only to ninety-four, or, including the red caps ( $f e z)$, imported fiom France and Genoa, they decreased from one thousand and sixteen to one hundred and twenty-four.*

As such facts may seem strange to Ameriean readers, the following extracts from letters of M. Botta, son of the Italian author of the History of our own Revolution, and late French consul at Mosul, may show that, however strange or distressing; at least they are not exaggerated. They are all of a later date; but, as they refer to the subject in hand, they are inserted here. Writing, December 8th, 184t, when the successor of Mohammed Pasha governed the province, he says: "Our

* Those wishing further statistics on this point will find them in Col. Chesney's large work, vol. II., appendix E, from which the above data ato condenser. 
pasha is as bad as when you left, and the poor Christians suffer just the same. They say that soon he will be removed, but I am much afraid of getting a worse one. There is no hope for these countries but in a radical change, and God only knows when it will take place. Patience is the thing now ; but mine is worn out, and I long for the moment when I shall leuve this miserable place.

"You have no idea how Khorsabad looks just now. It blows a hurricane, and the windows of heaven are opened on us. My 'castle' is demolished, and I live in a small room, in a dirty house, - the only one remaining in the village. I cannot thrust my nose out of the door. No work can be done, and I remain alone the whole day, musing upon the vanities of this world. Add to that my usual dẹbility and slow fever, and you will understand, perhaps, my situation. It is a comfort to me to think that you are just now almost in a cirilized country, looking on the face of my old friend, the sea. How much I love it! It makes me pensive, but never sad, and speaks a thousand unutterable things. Look at it, my dear sir, and think of me; let us hope that we shall meet again, - meanwhile, be happy, and believe me, \&c." This description of his situation at Khorsabad will be interesting to those familiar with his excavations there, which led the way in the wonderful discoveries of Assyrian antiquities since so successfully carried on by Mr. Layard.

March 23, 1845, he thus deseribes another pasha; for Shereef, the successor of Nohammed, proved ntterly inadequate to the situation:

"You are very happy, my dear sir, in having left Mosul before the arrival of our new pasha. He is, I believe, the most hideous man I ever siw ; four feet high, lame, crooked, with only one eye. one ear, and half a nose.* His face, too, most hor"

* Probably marks of punishment, inflicted for crime, according to the Moslem code. 
ribly scarred with small-pox. His soul is the fit innabitant of such a body. He is a perfect compound of every bad propensity, - cruelty, craftiness, greediness and lust. He cuts off heads, strangles people, throws others into the river, - generally for the sake of their property, but sometimes, as it would seem, merely for fun. I myself saw him firing bombs among the people, just to enjoy their fright. Besides, this horrid monster, when he hears of girls to his liking, in any family, sends his karasses to take them to his harem. The place would be deserted, but that he has walled up some of the gates, and posted solliers at the others, to prevent the people escaping from his chutches. My heart is sick, and I long for the moment when I shall leave this place, where I can only pity, but cannot help the misfortunes of my fellow-men, - God grant it may be soon ! The French govermment wish two of the largest winged-bulls transported whole. They weigh at least twenty-five or thirty tons each, and you may fancy it is no joke to move such blocks in such a country; but I hope I sball succeed." And he did succeed; the same carriage that he constructed with so much labor afterwards transporting to the river those exhumed by Mr. Layard, at Nimrûd.

June 29th, he writes: "Our new pasha is more quiet now ; he has left off strangling people, and now thinks of nothing but how to extort their last farthing. All his former severity was merely intended to frighten them, so as to prevent resistance to his rapacity. The Arabs come to the very gates and plunder at their leisure; but he does not care, - he wants money, that is all." The reader will be relieved to learn that this monster - Mohammed Kereetly (the Cretan), * as he was named, to distinguish him from the other Mohammed - was recalled by the Sultan, and now lives in disgrace in the vicinity of Smyrna.

* Compare Titus 1:12 and 13. This man is a striking illustration of the " evil beasts" of verse 12 . 
But, to return to Dr. Cirant. Shorty alter he came back to the city, the Jews were threatened with plunder and imprisonment, merely for seeking the benefit of the firman obtained by the British anbassarlor for their toleration, and were compelled to renounce it. This jealousy of foreign interference was constantly manifested by the pasha, as will apear more clearly hereafter. Another case, that occurred abont this time, is worthy of notice. A Christian, released from prison at the instance of the Finglish consul, was remanded back as soon as the latter left the city on a journey, and obtained his liberty only on his paying the sum originally demanded. It was well he was not in prison when the firman arrived that reserved to the Sultan the right of inflicting capital punishment. For then the pasha collected all the leading men to hear it read, and when he was sure that all understood it, he thus addressed them: "If the Sultan, or any one else, thinks I can govern Mosul without this power, he knows nothing about the matter." Making a sign to an attendant, the heads of those then in prison were thrown down before the assembly; and, after gazing a while at the ghastly spectacle, they were permitted to depart, glad to find that their own were yet safe on their shoulders.

It will be remembered that this took place in a region where newspapers were unknown; and no one who had family or fortune, within reach of the pasha, dared breathe a whisper to his lisadrantage. Communication with the capital, too, was so difficult, that a letter dated at Constantinople, June 20th, reached Mr. Hinsdale on the 25th of August !

Besides oppression, Mosul suffered terribly, in 1829, from the plague. Hundreds were carried out every day and thrown into a large pit, just inside the northern wall, where bones and skulls are yet risible to those who look down the narrow opening. Three years of famine had preceded it, and two years of the dreaded cholera followed; and then, as though all this had 
not inflicted enough of misery, came the seditions already referred to, as preceding the coming of Mohammed Pasha.

During the plague the father of Micha died, and a leading Jacobite, who fled with his family from the city, lost a child in the village whither he had gone for safety. Though the disease had not been there before, yet the woman who nursed the child, her husband and children, followed each other to the grave. He then escaped to the convent of Mar Mattai, a place deemed so sacred that plague could not enter there. But here he lost another child, and his brother saved his life only by cutting off the swellings as fast as they appeared. His next resort was to a solitary cave in the mountain ; and there his wife, too, died, and he was left alone. No wonder that not more than twothirds of the area within the walls is occupied with buildings, and that that constantly diminishes, as houses are torn down, and the stones burned into lime, to repair the remainder. The bazaars, especially, are ruinous. Whole streets of shops are literally turned into dung-hills; and in one covered bazaar the writer found only two dikkans (shops) occupied, out of twentyfour. Still, a small part of them, near the bridge and palacegates, are very much crowded. Citizens and soldiers, villagers and muleteers, horses, camels, \&c., literally choke the narrow streets.

November 4, Dr. Grant thus alludes to the trials of the mission, in a letter to Dr. Wright: "Our losses and the commotions in the mountains may retard our operations, but we are not in the least discouraged. Your remark is quite just, that, "though to us wars and tumults seem untoward, great and glorious results may follow them.' In the overturning among the nations, we must expect wars and rumors of wars. But 'It is I, be not afraid,' is the language God addresses to us. Should commotions continue, as they may do, till the Nestorians are finally subdued, we may find it necessary to work by occasional tours; but, at all events, we ought to stand ready 
to enter and labor, for a longer or shorter time, as the Lord of the vineyard may direct."

As soon as $17 r$. Hinsdale was able to travel, Dr. Grant left Mosul with him, November 19th, on a tour among the Nestorians between that city and Amadia. They had much intercourse with the Nestorians, Chakleans, Jews and Yezidees; visited the sacred place of the latter at sheikh Ari, and, after collecting much valuable information, and preaching the truth as they hal opportunity, they returned to Mosul, December 4th.*

Dr. Grant now felt that the independence of the Nestorians was virtually gone, and that the I'atriareh would do well to make terms with the Turks; and expressed these feelings freely to the Board at home, though, for good reasons, he said nothing to the Nestorians themselves. Duing this winter they made an attack on the district of Berwer, destroying a number of villages, and carrying off many of their flocks. This, he felt, showed more boldness than discretion, to say nothing of its injustice; and he rejoiced that he was not in the monntains, to be embroiled in such proceedings. "Still," he writes, "there is no room for discouragement, - none for delay ; but much for hope, - much for haste ;" and hoped to be able to enter in the spring, before the army of the pasha should render the road unsafe.

In the beginning of 1842 the two schools of the Jacobites were put under the care of the mission, - the first January 12th, and the other a month later. In the spring Priest Matthew returned from Mardin as Mutran Athanasius, his zeal in the good work no whit abated by the transformation; and Micha returned also, a more intelligent and valuable assistant, though not then, as he thinks, a converted man. Besides his more perfect knowledge of the Syriae, he had studied the Arabic also, though he has never made such proficiency in it as in the other. His knowl-

* For a full account of the tour, see Missionary Herald, 1842, pp. $310-320$. 
edge of it, however, was sufficient to secure his appointment as Mr. Hinsdale's Arabic teacher, April 11th, the day before the mission opened a school at Bertulla, and five days before they began another at Baashekha. Besides teaching Mr. Hinsdale, Nicha now set himself so diligently to the acquisition of the English, that he was soon of much assistance to the missionaries in their intercourse with the people.

Dr. Grant had written to Mr. Stocking, January 13th, "It is probable that the Pasha of Erzrum will unite his forees with those of Mosul and the Kurds, so as to strike an effectual blow at once at the liberties and lives of the poor Nestorians; and they must fall, unless supported, as hitherto, by an Almighty arm. This calls loudly on us to be fervent in prayer on their behalf. Perhaps I may pass in, and do what I ean, before the army enters, to prepare them for their approaching trials. But, before it is time to act, the path of duty will be made plain."

As spring advanced, he again looked toward the mountains; and Mr. Hinsdale would fain have gone in with him, to aid in the selection of a permanent station. But Mrs. Hinsdale was unable to do so; and, as the English consul had left on a visit to Baghdad, so that, if he went, she must remain alone, his going was out of the question. Still, though in February, Mr. Hinsdale had a serere attack, resembling the cholera, from which it seemed nothing but the unremitting attentions of Dr. Grant could have recovered him; and though Mrs. Hinslale also had been much benefited by his prescriptions, yet they would not for a moment detain him from the fiell. Trying as it was, in such circumstances, to be left alone, they even advised his going, trusting that He who had been with them in six troubles in seven would not forsake them. Mr. Hinsdale had already written home an appeal for more laborer's; and in that, after asking, "Are there no sons of the prophets, whose hearts burn with holy zeal, to "come over and help us ?'" and expressing his eonfidenee that such would be found, he adds, "But if not, - if alone we must 
bear the heat and burden of the day, - still we will rejoice to toil as God shall give us strength, and bless Him for the privilege till He shall give us rest."

It was a source of much consolation to Dr. Grant that Bishop Athanasius had consented to remain during the summer, when his presence was so much needed, both by Mr. Hinsdale, and the people among whom he still labored, as before, with Micha for his interpreter.

Ismael Pasha, the Kurdish chief of Amadia, had escaped from the Turks, and, rousing his tribe to rebellion, had plundered the convent of Rabban Hormuz and retaken Amadia, through the treachery of its Mutsellim. The Pasha of Mosul was now besieging the place, in turn ; and access to the mountains was so nnsafe in that direction, that Dr. Grant determined to attempt it from the Persian frontier. 


\section{II A P T E R X II.}

JOURNEY TO OROOMIAH - YEZIDEES AND MELEK TAOOS - ERBIL - CHURLISHNESS OF KÛRDS - CHIEF OF RAVANDOOZ - SCENERY - THE TOWN OF RAVANDOOZ - PILLARS AT SIDEK AND KELI SHIN-USHNEI - DIFFICULTIES AND DELAYS.

Dr. Graxt set out for Oroomiah June 6 th, attended by a young Syrian, who, besides his acquaintance with Kûrdish and Arabic, was qualified, by uncommon courage, for the expedition. He was tall and athletic, and to his two names, Baho and Abdulheiyat, added a third, Abderrahman, especially for the journey. A quilt boumd upon his own saddle, and a rug and hoorj (saddle-bags), containing a few books. medicines, fc.. on the mule of his servant. made up his whole outfit. Mr. Hinsdale and Bishop Athanasius went with them, the first day, on their way, to visit some of the schools; and the pasha's physician and banker accompanied all a few miles from the city. As they rode over the plain of Assyria, each band of reapers presented the customary offering of a small sheaf of grain, one of the many oriental modes of begging a present. The barley harvest was past, and the last of the wheat was fast falling be fore their awkward sickles. The fair sex - if fair they might be called, bronzed as they were by an Eastern sun - lent their customary aid; and the long ears of the donkeys were just risible under the loads of sheares they carried to the threshingfloors. On these oxen dragged round a sharp threshing instrument, having teeth, - Isa. 41: 15, - which rut the straw very fine. This, with barley, constitutes almost the culy foor of 
their horses and beasts of huden; - a custom as old as the days of Solomon. - $1 \mathrm{Kings,4} 2 \mathrm{2}$, - if not much older. Hay is not used, except in the mountains, where grain is scarce.

The road was the same he travelled on his first journey, as far as Barani, four hours from Mosul. Here they spent the night on the roof, the only refuge from the hungry swarms that rendered sleep impossible below it. This is generally safe; but the cool night wind, after his hot ride through the day, brought on a cold, that for a day or two threatened to put a stop to his joumcy. In the moming there was quite a stir among the Yezidees, to see the biazen image of a cock, which they revere, if not worship. It is carried from place to place on special occasions, or whenerer a Yeziclee pays enough to have his mansion blest by its presence. As the Noslems hate images, they deny its existence before them; but there is no doubt that they have it, though what it represents is not so clear, unless the name Melek Taoos (King Peacock), also used for Satan, may furnish a clue. They profess to have a book in a language of their own, and that only one family is allowed to read it. They observe the three days' fast of Jonah, as the Christians around them do, and say prayers prirately. Polygamy, though allowed, is practised by very few; and they observe a feast corresponding: to that of Easter or the Passover, and another at the time of the feast of tabernacles, or the feast of the cross in the Eastern churches. After breakfast they rode to Baashekha, where the Yezidees paid all due respect to the bishop, though they would not send their children to the same school with the Syrians, but asked for one of their own. From thence the company went on to Bertulla, where the mission had a flourishing school, which was alterwards supported by the people themselves, - a fact that deserves to be noticed, in view of the oppression that discourages every attempt ấ improvement.

They fourt a cool retreat in the church, though the mercury rose to $140^{\circ}$ in the sun. The people crowded around them, and 
gave them a pleasant opportmity to try to do them goorl. Aiter some refreshment, the hishop led in prayer" (in English) for a blessing upon each of them and on that dark land, and thus they parted. With the bishop Dr. Grant never met again, though there now lies before the writer a letter from him, dated Cochin, February 15th, 1845, addressed to Dr. Grant, nearly a year after his death. In it he says, "After my arrival here, there was a great deal of quarrelling anong us ; but, by the blessing of God, there is rest now. I have been risiting all the churehes in the interior of Malabar. The people receive me with great ioy, and hear the word of God gladiy. I trust that God, in his good time, will remember and have pity on us, and exalt us from our fallen estate."

Dr. Grant was now alone, with a single native attendant, and a perilous enterprise before him. But, feeling that "the path of duty is the only path of safety," he rode cheerfully along. Four hours ride, wer a rich, undulating plain, watered by the Hazir, brought him to the Zab, - probably the Zerbis of Pliny (Ches. ney), where he spent the night in the open air.

Next morning he rose early, and floated across on a raft, supported by inflated skins, at a village named Kellek (raft), while his mules swam over, guided by a man supported by a single skin, exactly as represented in the Assyrian sculptures of Nimrûd.

Eight hours brought him to Erbil (Arbela), which gave name to the great battle that made Alexander master of Persia, - a fact utterly unknown to the seven or eight thousand motley tenants of this once fitmous city of the Arsacidre. The Moslem Sahibs of Erbil, whose power extended far into Persia till subverted by the Turks, have left a minaret, one hundred and twenty-one feet high, now far out of the town, as a monument of its greater extent under their administration.* The artificial mound on which the castle 
stands presents a beantiful aplearance, with the distant Kûrdish mountains in the back-ground. Rich calls it about one hundred and fifty feet high, and three or four hundred yards in diameter. In the time of the Nicene Council this was made the Christian metropolis of Adiabene, by Papa, Primate of Seleucia. There are about two hundred. Jewish families in the town. Some of them sell the Parthian and Sassanian coins they find here in Mosul and Bagdad; the rest of the inhabitants are Mohammedans. Dr. Grant stopped at the Chaldean village of Ainkowa, three-quarters of a mile from the town, and found the people with all the opemess of the Nestorians, but forbidden to read any rolume that had not the imprimatur of the Pope, - thus, in fact, forbidding them to read the Scriptures altogether. Though, at first, they gladly received the gospels printed by the British and Foreign Bible Society, they had afterwards been compelled to destroy them. Thus far his course was sonth of east. He now turned nearly due north, on the most westerly of two roads to Ravandooz; and then, bearing north by east over a low range of hills, reached a Kûrdish castle at Deir (convent). An ancient church is said to have stood here once, and he suspected the castle occupied its place. There must have been a multitude of churches here in early times; and where are they now? There are numerous ruins between Mosul and the Hazir, but, thence to Oroomiah, they are yet to be discovered. A few villages - one, an hour beyond Ravandooz, and some others he lieard of, a little off the road - have gone over to the Pope. These had been told the usual story of the whole world having become Palral; and the change required appeared so slight, they yielded to the proffered temporal advantages. And thus all the Nestorians, from Amadia, the mountain tribes and Oroomiah, as far south and east as Semah, have passed away, or are changed ouly in name, and a wider renore from gospel influence.

The day following, after a hard bed on the ground before the castle-gate, and a breakfast of hard-hoiled eggs and halt-baked 
barley bread, he proceeded, with a footman for guide. A horseman had been promised, to go as far as Ravandooz, but did not appear; and he was glad to get off with no worse treatment. The region is noted for its hatred of Christianity, especially of Franks, who are regarded as its strongest bulwark; and every step furnished proof that it is not belied. The late chief had been noted for his strict adherence to Mohammedan law, cutting off one hand for the first theft, the other for the next, the head for the third, \&e.; and Dr. Grant found evidence of his strictness in three suceessive guides, each blind of an eye. The chief himself had only one eye, and may have taken special pleasure in reducing others to the same condition. He was usually called Koor Bey (blind chief); but his name Mohammed was equally appropriate. His footsteps were marked with the blood of Christians, and all unbelievers; and his coffers were filled with the plunder of villages and churches, from Aderbijan to Mesopotamia, and as far north as Amadia and Jezira. The Yezidees, espeeially, were mercilessly slain, - in many easca, doubtless, a just retribution. Many Christians still pine in the slavery to which he consigned them. When Dr. Grant first came to Oroomiah, he stripped Mergawer of everything, and put to the sword all who resisted; and it was only on the approach of an army, headed by Col. Sheil, that he retreated, with his booty, to his own dominions. The next summer the Governer of Aderbijan was sent against him; and he escaped only by surrendering to Reschid Pasha, who attacked him at the same time from the Turkish side. A pledge was given, under oath, that his life would be spared, and he was carried prisoner to Constantinople. After a year or two he was permitted to return; but a kavass overtook him near Siwas, and a cup of coffee, prepared aceording to order, relieved the government from all further apprehension.

With all his cruelty, he was mueh beloved by his people, who still boast of the security that prevailed under his sway; for woo 
betide the man who picked up an article on the road, however valuable, or however long it had lain there, unless he was its owner. He moisopolized the gall-nuts of his province, receiving two-thirds of the crop as his share; and ordered two men, who had gathered theirs without paying him his quota, each to lose an arm. Even a moollah, with whom some twenty-five nuts were found, was fined sixty dollars. One of his own servants had eaten a bowl of stolen yoghoort, and yet denied the theft; the sword of the terrible chief at once laid bare the stolen prorerty, and inflicted a terrible punishment on the offender. One of the last things he did, before his surrender, was to put out the eyes of a faithful firiend, who came to warn him of his danger. But, besides being the bearer of eril tidings, - which, in the East, is a heinous offence, - he had left his post without orders, and, therefore, he found no nercy. His master is dead; but this chief still lives, a monument of the terrible reign of Mohammed Koor Bey, of Ravandooz.

After a refreshing sleep under a tree, not far from a village, in the hills of Herir, that looked more like a den of thieves than the abode of honest men, Dr. Grant rose before the sun, and had a delightful ride of three hours to the romantic town of Ravandooz. The Zab, which had been in sight most of yesterday, now broke through an abrupt chasm on the right, perpendicular clifis of limestone rising high on either side. It here receires the Ravandooz ricer, enlarged by two tributaries fiom opposite directions. The scene was peculiarly grand as he looked down on it, nearly fifteen hundred feet below. The ascent, though steep, had been so winding, that he rode to the summit, orer a road sometimes cut into the very face of the clifi. The description of the same place, by the graphic pen of the licr. D. W. Marsh, eight years after, presents the scene so vividly, that no one will regret its insertion. He says:

"Although familiar with the grand scenery of the Catskill and the Green Mountains, never before have I seen so sublime a 
pass. The vast height of the pinnacles, the roar of the torrent and resounding cliffs, and the solemnity of star-light, combined to awe and rejoice the soul. Huge fallen crags lay confused along the steeps. Imagination was busy. Wherever space allowed, trees threw their giant arms, as if to hold the traveller from whirlpools below, like a mother's fond yet vain embrace, when the avalanche comes thundering down. Just where the footing grew scanty, the road was erowded on to a rude bridge over the boiling waters. Scarcely discerning anything earthly, we seemed like spirits wandering in wonder. Were those apparent crags and precipices realities? Are these, indeed, luxuriant trees, clinging to the mountain-side in the very path of the avalanche? Hingled with the midnight roar of the cascade, is this the tinkle of caravan bells? And now, was that shout the language of friends, or the Arabic of a Moslem? Is not this all a dream? How strange the reality! Alone with those not one of whom knew a word of my native language, climbing, by starlight, the mountain-passes of Kûrdistan !

"As the moon rose we were still climbing, rising to the majestic mountain-tops; now at the edge of a cliff where a fall would have been death, our horses and mules panting as they struggled up; again, a horse falling, fortunately into the pathway, and not over the precipice; and anon gazing down without giddiness at a distant cascade, tumbling into an abyss so profound that no sound struggled up to us even in the stillness of night. In four hours we must have ascended twenty-eight hundred feet, to the grandew of the home of eagles and the storm." "Just here," says Dr. Grant, "I met our messenger from Mosul, returning with letters from Oroomiah, - an unlooked-for feast in such a place. I gave him a note to the dear friends I had left, which he carried in safety; but the next I heard of him he was killed, by the Kûrds, on the very road I then passed over unharmed. After one more look at the plains of Mesopotamia and Assyria, from the top of Sar Hasan Bey, I arrived, by a 
gradual desecent, at the town." This cecupies a strong position, with the river flowing round the north and west, between steep, rocky banks. A ravine and embankment protects the remaining sides, and the whole is defended by ramparts and towers, sufficiently strong to resist any attack of the neighboring Kûrds. As one looks up, however, from the river, the flatroofed houses, rising tier above tier, like seats in an amphitheatre, expose the whole town to the eye, and the camnon of more civilized invaders. The population may be nearly a thousand houses, of which about fifty are Jews', with whom Dr. Grant conversed freely in the Nestorian language. The chief - a brother of the famous Koor Bey - did not deign to notice the doctor's firman, or even treat him with common civility. After sitting two or three hours outside the room where he was, he says, "I was glad to get away, rejoicing that, unworthy as I was to suffer for Christ, all this scorn was poured upon me for his sake." A caravan was just leaving for Persia, and he was only too happy to join it at once, and leave the place. They encamped some four miles out, in the open air; and, as the horses were huddled together for fear of thieres, he was in danger of being trampled on by them in his sleep.

He reached Sidek June 11, which $\mathrm{Nr}$. Ainsworth thinks was a fortified post, on the royal road from Nineveh to Ecbatana. Several Jewish families have lived here from time immemorial. They are simple and open-hearted, and received both the Old and New Testaments joyfully. The latter they had never seen before, but promised to read it carefully. He had a long conversation with them in the Nestorian dialect; and when he left they followed him some distance on the road, and gave him their parting blessing.

Next morning his Kûrdish host sent two men to escort him safe into Persia, - a favor all the more welcome, as murders had just been committed on the road, and Persia and Turkey seemed on the eve of war. About half an hour from the village he 
came to a stone pillar, with euneiform inscriptions, which had not before, to his knowledge, been visited by Europeans. Mr. Ainsworth missed it by looking for it at the village below. It had apparently been broken off at the top, and was inscribed only on the side facing E.S.E. Next morning he reached the large pillar at the top of the mountain. His guide would hardly suffer him to dismount, and the caravan called out to him not to stop; but he examined it, nevertheless, till the guide would wait no longer. As Major Rawlinson was hurried off in the same manner, and it was not even shown to Mr. Ainsworth, Dr. Grant conjectured that the people fear lest Europeans discover in the inscription a claim to the country, as they say it is written in the language of the Franks. The character, so far as he could judge, was the same which he had seen at $V$ an, and similar to that he saw afterwards at Khorsabad. But, as the difference is not readily apparent to an inexperienced observer, he does not speak decidedly. Major Rawlinson says the pillar he saw faced to the east, and was inscribed only on one face; but this faced southeast, or even more south than east, and was plainly inscribed on both sides, having a line or two less on one side than the other. The stone was of a light blue or greenish color, - hence the name Keli Shin (Green Pillar), - very hard and compact; and, though exposed to the storms of more than two thousand years, the inscriptions are so well preserved that, under favorable circumstances, they might be copied, by an experienced hand, with scarce the loss of a letter.

He spent the night previous under the shelter of some rocks, at an elevation, by boiling point thermometer, of eight thousand five hundred feet; and, judging the ascent thence to the summit to be fifteen hundred more, he estimated the pass to be, in round numbers, ten thousand feet high. There was much more snow, however, on the Jelû mountain, a month later, the year before. Still, even here he crossed a torrent on a bridge of snow, far below last night's encampment; and in the morning 
he found the little rills frozen, and the gla iers so extensive and slippery, it was really hazardous to cross them. He describes the riew from the summit as surpassingly sublime. "To the south and west a rast sea of mountains was spread before me, wave rolling on wave, and here and there bursting in foam, for such appeared the snowy summits glistening in the morning light. The vast plain of Mesopotamia stretched in the distance further than the eye could reach; and in the opposite direction the Lake of Oroomiah sparkled in the sun, apparently just below me. I had been familiar with its beautiful outline for so many years, that, all at once, in these wilds, I seemed to have met the face of a friend. The sight was as exhilarating as the sight of home; and, but for the longer journey before me, my toilsome pilgrimage would have seemed almost over.

"Hastening down the mountain, I was glad to pass safely the last camp of the nomad Kûrds, who rob the traveller here with entire impunity. They are too numerous to be subdued, except by a large army; and the approach of that allow them time to flee to fastnesses that defy pursuit. They commit the most daring robberies just before changing their quarters in spring and autumn, as at those times they ean best make good their escape."

Once out of danger, he hurried on before the caravan, forded the Ghedar, and, crossing a rich alluvial plain, entered Ushnei, and was hospitably entertained by one of its fourteen Nestorian families. These form the remuint of a large Christian population in ancient times. It was formerly a metropolitan see; and one of its incumbents aided in the ordination of the Patriarch Jaballiha, in 1282. There are thirty families of Jews here, speaking, as usual, the language of the Nestorians. To both sects Dr. Grant gave portions of the Bible; and the Jews, after some hesitation, promised to read the New Testament, as well ais the Old. Wherever he went, he found more readers among them than among the Nestorians; and attributed it to their habits of trade, compelling them to be able to keep accounts. 
In the morning, an unusual number of the siek, lame and blind, erowded around, as soon as they heard that the old Hekim Sahib, of Oroomiah, was there. Even the harem of the governor honored him with a visit in the evening, and in the morning sent him a pleutiful breakfast, from their own table, that tasted all the better for the hard fare of the journey.

It was lite in the afternoon before he could get away, as the governor detained him to escort an instalment of tribute to his superior at Oroomiah. Two or three foot-soldiers were left behind, as soon as they were out of reach of the Kûrds; and at midnight, as it was too dark to eross the Barandooz, he slept in an adjoining village till morning; then, quickening his pace, over a plain that seemed more beautiful than ever, - passing now by fields almost ready for the reaper, and now by vineyards and gardens, meeting with familiar faces under the trees by the roadside, - he was soon among his loved associates in the missionhouse. It was pleasant to meet so many dear Nestorian friends, after more than two years' absence; but more delightful to enjoy Christian fellowship with missionary brethren, after so long a sojourn in the tents of Kedar.

Next day the mission assembled, and resolved unanimously to send one of their number with him into the mountains. Mr. Stocking, who had been much interested in the enterprise from the first, was chosen, and two of the best native helpers appointed to aecompany them. They hoped thus to do mueh by way of preaching, and so lay a broad foundation for future labors. Dr. Grant desired too to make the most of aceess to the mountains while it lasted. He writes, "The cordial interest with which all the brethren entered into my plans will ever be one of the most pleasant memories of my missionary life." Dr. Wright says of him, at this time, "Amid his active preparations for his mountain eampaign, with the heavy eares of that enterprise upon him, and with the most perplexing questions of 
duty often arising, his spirits were buoyant, his step was elastic, his energy untiring."

As soon as he could make his arrangements they set out for Salmas, taking letters from the governor and some of the nobles of Oroomiah to Yahya Khan and the emir. Providentially they found them both at the favorite castle of Charreh, which is perched on the summit of an isolated rock, near the river of the same name. The green banks of the stream were now dotted with the tents of more than a dozen chiefs, assembled to meet the emir. He had come in state, with two hundred attendants, at the instance of the Persian government, which sought his aid in the expected war, and swore, on the Koran, perpetual allegiance to the Shah, who, in turn, promised support against the Sultan. Thus ended his alliance with the Porte, formed two years before, in hope of immediate aid to subdue the Nestorians. He was now about to assist Ismael Pasha in the recovery of Amadia from the Turks.

In such circumstances, Dr. Grant was cheered to find the emir still regard him as his physician and friend, and urge him to accompany him to Julamerk, whence he promised to send him in a few days to Tyary. Suleiman Bey earnestly seconded the request, and proposed to go there with him in person.

Dr. Grant's plans and objects were now fully explained to the emir, in the presence of the Khan, who confirmed each statement from his own observation of missionary labors at Oroomiah; and in his presence Nûrullah Bey promised to protect Dr. Grant and his associates, and permit them to erect buildings for themselves and their schools, as they should be needed.

The warlike aspect of the mountains looked forbidding. But at a time when war was threatened at every point, those secluded valleys seemed to promise as safe an asylum as any. other part of the country, and the friendly disposition of the emir encouraged them to proceed. 
Just at this crisis, the alarming illness of a child of $\mathrm{Mr}$. Holladay recalled Dr. Grant to Oroomiah ; and hoping thus to consult with the mission, and return in time to go in with the cmir, he immediately set out. By riding all night, he reached his patient, sixty miles distant, in twelve hours; though he was sick when he mounted, and continued to grow worse on the roarl. Care and anxiety, joined to his old enemy, the malaria of the plain, doubtless occasioned his illness, and showed that though his indomitable energy kept him from a sick bed, yet he was by no means well. Medicine and the kind nursing of friends soon afforded him relief; and, though for a time the life of the child hung in suspense, he too was soon so far out of danger that Dr. Grant was about to resume the enterprise, when Mr. Stocking was taken ill, though not so sick that he might not profit by the journey.

On the 14th of July the two missionaries rode twelve miles to the river Nazloo, one of the four large streams that water the plain, and were hospitably entertained in the house of Priest Yohanan, who, from being a drunkard, had risen to be a most valuable native assistant. Their little chamber over the gate, the only upper room in the village, might have been of the size of Elisha's; but, small as it was, it afforded the retirement a traveller in the East knows how to prize. Next day they hal two or three times in the course of twenty miles, and were exceedingly refreshed by bathing in the lake. They found it impossible to sink lower than the shoulders in an upright position, and a saline incrustation was left on the skin from the excessive saltness of the water. As they passed along, the people were just gathering their harvest, a work finished at Mosul nearly six weeks before; while on the high lands round Julamerk wheat was still green, on the 26th of August, 1844.

They spent a quiet Sabbath at the house of Mar Yohanan, then absent in the United States. And here Dr. Grant was again threatened with fever; but a timely use of medicine, apd two 
days' repose effectually relieved him. Mr. Stocking preached twice, on the Sabbath, to a congregation assembled under the spreading branches of a walnut-tree. The aged father of the bishop was one of his most attentive hearers. "What a change," says Dr. Grant, " will there be, when, instead of prayers in an unknown tongue, this whole region shall be supplied with a pious and well-educated native ministry! This is our aim; and, by the blessing of God, we hope to attain it."

After a hot bath at the sulphur springs of Isty Sû (warm water), temperature $106^{\circ}$, they reach Oolah on the 18 th, where the mission had a school, under the care of an aged priest. Unhappily, they had to tell one of his sons, who acted as his assistant, that neither they nor their patrons in America could employ one given to wine. He appeared humbled, and Dr. Grant hoped that he might reform, as others more confirmed in the habit had already done. The school, in other respects, was doing well, and was much needed in a district containing more Chaldeans than all the rest of Persia. They number two hundred houses, mostly in Khosrova; and in their catechisms, printed at Rome, the second commandment, as usual, is omitted. The Armenians of the district, numbering about one thousand houses, earnestly desired schools and books.

At Khosrova, where they went next day, Dr. Grant had often found a pleasant home with a cousin of Mar Shimon, wife of Waly Khan, the last heir to the throne of Georgia. Before their marriage, they not only had not seen one another, but each was entirely ignorant of the other's language. In former visits he had found them comfortably supported by a pension from the Persian government. But now she was trying to sell the few thing: she yet possessed, to procure the means of returning to her mountain home. Her husband had died at Teheran, and the first netrs she had of his decease was the withurawal of his pension, thus plunging her at once in widowhood and want.

Her brother had married the younger sister of Mar Yohanan; 
and, though he too never saw his bride till she became such, he certainly had no reason to complain; for the bishop, stimulated by the example of the missionary ladies, had taught her to read, and $D_{r}$. Grant describes her as a most interesting and amiable young lady. He says that he seldom was more delighted than when, seated in a chair, in her house, he listened to her reading the publications of the mission press.

These two ladies, and those mentioned in page 139 , are all he ever met with who could read, except those taught in our schools; and, as such, he always took a special interest in theil welfare. Others hereafter may excel them in acquirements, but the two sisters of Mar Shimon, and his cousin at Khosrova, like David's worthies, will always be the first three.*

As Mr. Stocking grew worse, instead of better, it was now thought best for him to return; a circumstance the more trying ti) Dr. Grant, as both the native assistants had become so alarmed at the dangers before them. that they also declined to go further. It was now a trying question to him whether he also should turn back with the rest. The Kûrds on cither side of the frontier were already committing robberies, in anticipation of the war, and the future looked dark enough. But, after weighing all the circumstances, he felt that the valuable opportunities which might otherwise be lost justified him in going forward. True, there was risk; but it seemed better to risk a little more than incur the danger of losing all the ground already gained. The tenpest seems to have been made to beat upon him on purpose to illustrate the safety of the man who trusts in the Most High. At the very last moment, he succeeded in getting the courageous Mar Yoosuf for a companion. It was a good arrangement. whether we consider the dangers to be met, or his official intluence in favor of the truth.

Just $a^{4}$ this time, Dr. Wright and Mr. Breath providen- 
tially appeared to ait their counsels; and at an early hour, July 21 , in an imer apartment, the missionaries affectionately commended each other to Him who had promised to be with then always, then mounted and rode off in opposite directions, they to their quiet home and peaceful labors, and Dr. Grant and the bishop to the wild mountains of the yet wilder Kûrt. He now shaped his course for the castle of Charreh, with tho fortified city of Dilman in the rear, and the Sheher (city), at old Salmas is usually called, on the right.* The remains of two minarets are visible outside the town.

He now left the plain, covered with villages embowered in gardens among fruitful fields, and descended a steep ledge of igneous rock to the vale of the Charreh. Ascending this, he had a wall of columnar basalt on his right, rising abruptly about two hudred feet. Some of the columns lay in fragments in his path. There were numerous grottoes, and he had heard of inscriptions; but those pointed out were mere linear irregularities in the rock. At a sudden turn in the road the castle came in sight, forming a very picturesque object in the quiet lanuscape. This is the ancestral estate of Yahya Khan, who, besides being Governor of Salmas, is chief of a branch of the Hakkary tribe. He married a sister of the emir, and gave him one of his own in return. Another is in the harem of the Shah. And this double alliance, together with his reputation for integrity, give. lim great influence with both Persians and Kurds. Hence his fuccess in negotiation, as in the instance already described.

The emir hat gone; but the Khan, who had been expecting Dr. Grant, was ready at once to speed him on his way. At a yrivate interview, his guest asked whether he had any fears for lit: afety with the emir, or whether the latter would allow him to go to Mar Shimon, as he had promised. In reply, the Khan assured

* Mr. Ainsworth strangely confounds the two, notwithstanding Dilman is modern, and old Salmas, thongh now a mere village, still retains the name of its better days. 
him there was no doubt of the ehief's personal friendship; and offered to write to him, either to allow him to earry on his mis. sionary labors, or send him back in safety if he was opposed to them. A eertain anxiety manifested by the Khan in reference to his journey prompted Dr. Grant to make this inquiry. But he explained it by telling him that the P'ersian nomads had plumdered tha Turkish frontier, for which retaliation was threatened, and that on this account he felt uneasy. 


\section{CHAPTER XIII.}

FO IRTH JOURNEY THROVGH THE MOUNTANS - ADVENTIRE AMONG THE OMAD KíRS - RANDI KILEESEH - MINERAL SPRINGS - KÛRDISH IXh.)SPITALITY AND HURDERS - TRAVELS WITII THE EMIR - NESTORIANS GF T.LL - CAMI IN TEIOMA - JOURNEY TO JEL $\hat{\mathrm{U}}$ - A NIGIIT ON TIE MONTANS - NESTORIAX TELEGRAPH - BASS - BLOOD FETD AN1 REGRCLLATION - KÜRDISH LIFE IN CAMP - TEHOMA - AVALANCHES - NESTOIIAN COOKLA - THOUgHTS ON PEACE - MEDICAL PRACTICE - A NARROW WAY - HEART OF THE MOUNTAINS - HEIYO THE OUTLAW POUNTAIN ROADS AND BRIDGES - LITE IN ZOZAN - RETURN TO ASIITHA IGLITICS - IERTÉSI CHIEF - MISSION-HOTSE - EMIR'S PERMISSIOX TO EUILD - FAILURE OF ExPEDITION AGAINST AMADIA - SYRIAC DEED OF REAL ESTATE.

Dr. Graxi was on his way by early dawn on the 22d, with two rough-looking Kurds from the sources of the Zab, and soon comprehended the cause of the Khan's uneasiness. The caravan was again interrupted, as on his former entrance, but for another reason. The Kûrds near Van, with the Turkish soldiers there, were actually on their march to inflict the threatened retribution; and this news, brought in by their scouts, had set all the guilty tribes in motion on the mountains before him. It was one of those scenes not to be forgotten by the observer, though no language can describe it to another. The road was literally thronged with the frightened fugitives, - men, women and children, crowded on each other, terror visible in erery feature. The little ones, packed on the loaded animals or slung in large sacks fastened together across the backs of the cattle, were crying as they went. Women, on foot, urged, with cries and blows, the slow-footed beasts loaded with their baggage, leaving husbands and brother: to drive the flocks. Some, whose loads had fallen in the road, were jogged and jostled by the 
rtst, none caring to stop long enough to help them. Then the filocks eame in from every side, compelling the little party to wade among them as through a flood. But it was worth detention to witness the scene. A moving mass spread far and whe over the hills, presenting the appearance of an animated landscape. At the first camps the tentis were still standing; further on, all was bustle, striking and loading them on bullocks, don. keys and mules; and still further, all hurried forward together, like a vast army in its flight.

As they met clan after clan, poor Baho, bold as he was, begged to return. But his master pressed steadily on, soothing his fears, the while, by suggesting expedients they might resort to, eren should they meet the army. After stemming the thickest of the erowd, they quickened their pace, and beyond Khaneh Sar hiud the road almost entirely to themselves. Till then his Kaidish guides had been very civil. But now they could not resist the temptation of a stray colt that followed them, and made it their prize. But Dr. Grant rode forward to the last party they met, and told them how the matter stood; and, though his guides stoutly maintained that the colt belonged to them, they were compelled to give it up, and vented their anger on the loctor for his interference.

It showed something of the courage of faith, to maintain his integrity at such a time, and incur the wrath of lawless men in their own strongholds, rather than, by becoming party to a theft, incur the wrath of God.

This pass, at an elevation of only eight thousand feet, is comparatively easy; but, like all the rest, is dangerous from the roving freebooters who frequent the extensive pastures in the vicinity. The waters flow from this range, the Sar Albakh, to lakes Van and Oroomiah, the Caspian Sea and the Persian Gulf. As the party descended towards the Zab, the father's heart was moved by the sight of the spot where, two years before. his little son had slept in his bosom amid the snow. At Kandi Ki- 
leeseh he was the guest of a petty chief, in a castle that overlooks the Zab. He visited the Armenian church, which gives name to the place; and found it built of stone, deeply furrowed by the mountain storms. It is one hundrer feet by sixty, and is surmounted by two domes and a bell. Unlike other buildings in the region, it has a sloping roof, with regular gable-ends, and corered with stone instead of tiles. The rartabeds assured him it was seventeen hundred year's old (they told Mr. Ainsworth sixteen hundred); and, professing to derive their anthority from the ancient Armenian inscriptions, they point out the tomb of the apostle Bartholomew, who is said to have preached or suffered martyrdom on this very spot. The church is surrounded with a wall and bastions, and has an outer and inner court, with rooms round about them. Its linds support the clergy, and pay a tax to the Bey; but there are few Armenians in the vicinity.

Next day his road followed down the Zab, - here called Albakh, from the name of the district. This is a large, irregular opening among the mountains, and, from its ruined rillages, castles and churches, seems onee to have been densely peopled; now it is mostly given up to the nomad tribes. Bash Kala, the only village of note that it contains, three hours after leaving Kandi Kileeseh, stood a few miles to the right, his course being at first west-south-west and south-west, then south and southeast, and south-west again. Two hours further he passed a number of springs; some as high as eighty and ninety degrees, Fahrenheit; others cold and effervescing like a soda-fountain, or hissing down among the crevices of the rocks. In one place they had deposited a ridge of calcureous tufa, about two hundred yards long and twenty feet high. The springs occasionally change their place, and he sought in vain for six that he had seen in a row on his former visit. He was even more interested, however, in the little companions of his childhood, "the humblebees," that here, for the first time in the East, he saw gathering honey from the red clover-blossoms by the roadside. These, 
almost as rare in that country as the industrious insects that rifled their sweets, grew wild amid a variety of beautiful flowers.

Passing the Nestorian hamlet of Atis, where he ate some black bread and yoghoort, he arrived, seven P. I., at the Kûrdish village of Zarany; and there he had to sleep before the door, after begging in vain for a shelter from the cold. He could scarce get anything eatable for man or beast; but was thankful to leave, next morning, with an empty stomach, rather than fure worse.

Two hours further on, they were told that a Persian caravan, from the orpiment mines, had been plundered, and several of the men killed, just before them. Soon one of the dead bodies was earried past, and Baho again begged him not to rush into the fire where others had been burned; but he knew there was a fire behind as well as before, and that, ere this, retreat was cut off by the invading army. He judged, too, - and it shows the accuracy of his observation, - that, as the deed occurred in the night, the robbers had ere this fled elsewhere with their plunder. So, trusting in God, he rode on, and before night was safe with old friends in Kochannes. This former abode of Mar Shimon is beautifully situated, in a level upland valley; and, except the opening by which he entered, is surrounded by a wilderness of mountains, whose melting snows pour down a plentiful supply of the purest water. Finding it too much exposed to his enemies, the Patriarch, years ago, left this pleasant home of his predecessors and removed to Diss, where he could be better defended by his warlike elans. This increased the jealousy of the emir, and resulted in the invasion of the year before, when the house of the Patriarch was burned, with the loss of everything he could not carry away in a hasty fight by night.

From this place, more than six thousand feet high, he gradually ascended another thousand, if not more, to Berchulla, the summer residence of the emir, where he was kindly received, and quartered in one of the huts, built of loose stone, and covered 
with boughs. It was the same place where Dr. Smith and Mr. Taurie visited him, in Augnst, 1844.

Ismael Pasha was here, about to leave with Suleiman Bey, to enlist the Patriarch against the Turks, and they proposed his going with them; but he gladly seized on the illness of the emir as a pretext to avoid it, lest he should become entangled in their political movcments, - especially as the latter promised to sem him on to Tyary as soon as he himself should reach Tehoma.

At the emir's suggestion, he now exchanged his Frank drest, for their own costmme, and soon was seated, "a la Kûrd," dipping his hand with him in the dish, to good purpose, if not with all the finished grace of an oriental. At the chief's table he had no occasion to complain of hard fare, though the Kurds, in general, are simple in their diet, and far more temperate than either the Persians or Turks in the matter of intoxicating liquors. They were surprised and pleased to find that in this last the doctor agreed with them; for, though none are before them in zeal for Islam, and they do not scruple to call the Sultan himself a Giaour, for his Leropean innovations, yet they appreciate consisteney of this kind, and express great abhorrence of Intidelity and Atheism.

The emir set out for Julamerk July 28, on his way to Amadia. After the crowd had left, Dr. Grant enjoyed himself very pleasantly with a few friends that remained, among them the mother of Suleiman Boy, who, from first to last, showed herself truly friendly. She had not forgotten little Henry; and cautioned his father against the treachery of her people, and especially the jealousy of the emir, - a trait he had had occasion to notice more than once. He had not forgotten how he looked when he found his cousin writing a letter for the doctor to Yahya Khan, till, on reading it himself, he saw how baseless were his suspicions. As they rode slowly down, he enjoyed the wild mountain landscape, - the rough peaks rising sharp above the banks of snow that glittered on every side. A descent of two 
thousand feet brought him, in two hours, to the castle of Julamerk, which $\mathrm{Mr}$. Ainsworth makes five thousand four hundred feet above the sea. Here the soldiers on guard went through a sham-fight before they admitted the emir and suite. It was near dusk, and the repeated volleys fired by either party, reverberating among the crags, followed by a closer contention with sword and shield, presented a graphic picture of Kûrdish warfare, much more agreeable than the reality.

On Friday Nûrûllah Bey would not proceed, as it was his Sabbath; which gave Dr. Grant an opportunity to ask to be excused from travelling on his, to which he at once asschted. At noon he went to the mosque in state, preceded by an Arabian derwish, fantastically but richly dressed. Friday is unlucky there, as well as here. But next day, at noon, all set foot in stirrup the moment the stars were propitious, except Dr. Grant, who, thinking more of comfort than of the stars, went on before, and waited for the cavalcade by a fountain some distance down the ravine. From thence to the river even the emir was conpelled to walk, so steep and dangerous is the road, though built up against and cut into the precipice, at great expense. Across the Zab the road was so difficult that even the mountain mules could hardly get on without their riders; and the reflected heat of the narrow chasm - valley there was none - was so intense that the emir nearly fainted. A little peppermint soon revived him ; but this, and the effect of a cup of tea, on a similar ocuasion, led him to throw out such hints, that the doctor began to fear he was enlisted for the campaign, till he lost some of his credit by bandaging the arm of the chief, after bleeding, so that a drop of blood, oozing out, spoiled the virtue of his evening prayers.

It was quite dark before he reached the largest and highest of the six Nestorian villages in Tall. As this district is small, it pays tribute to the emir; and, sad as is the tale, yet it is true, that its inhabitants are, on this account, despised, and even plundered, by the other tribes who are aler from attack. The 
only level place not cultivated, that Dr. Grant could find for his mules, was the roof of a dwelling, which formed the door-yard of the house next above. The people were miserably poor, but readily shared with hin: what they hat. His mules fared the worst, however ; for grain is so scarce in all the mountains they reem it a sin to feed it to beasts. This tribe has the name of heing more rude than others; but their country is so sterile it is not to be wondered at, and will, therefore, be hard to remedy. They occupy the deep, narrow glen of a tributary of the Zab. A church, high up on one side, is the only object worthy of notice; and that was so difficult to reach, the doctor did not visit it. The emir, according to promise, let him rest here on the Sabbath, though to the former it was a day of feasting and hilarity,while Dr. Grant improved this only opportunity to do good to the sick, and the bishop afforded much aid in directing their unwilling minds to the Great Physician.

At an early hour on Monday, August 1, they commenced to ascend the mountain toward Tehoma. It seemed like an impassable wall, mocking their approach. The repeated salutes of two hundred men of Tehoma, who claim the summit as their border, echoed and reëchoed through the glen. It would have been easy for them to have overwhelned ten times their number; but the emir had shrewdly selected one-half of his attendants from their chief fumilies, and in this and other ways secured an influence which he knew how to wield against the more powerful tribe of Tyary. Their waste of powder - for they continued firing till the emir reached them - would have surprised any one who did not know that each man makes his own, just as he makes his own shoes and hat, and produces his own food and tobacco, so that there is not a market or bazaar in all their country. Descending to a spacious upland valley, far from any village, the emir encamped there, and made it the rendezrous for the army against Amadia.

Having no taste ff $r$ such a life, Dr. Grant hurried off on a 
visit to felû and Bass. With a guide from Nûnllah Bey, he turned to the north-east, passing two or three summer camps of the Nestorians. From the last of these some of the villages of Jelì were visible. It seemed as if a rapid descent would bring him to the nearest before sunset. So, without stopping to eat the simple fare offered him, though really hungry, he pressed on. But he found his guide knew little about the way. The ravine was so filled with immense banks of snow, cut perpendicularly by the torrent, and the sides were so steep on either hand, that the passage of mules was hopeless; he therefore made a long detour to another, and sunset found the party walking down a deelivity so steep that the mules could hardly follow, and when they did it seemed as if they would precipitate all before them. They had never seen such goats' paths before, and turned back their heads in silent expostulation, as the party tried to drive where they dared not lead. At length they found a little green sward amid the snow; and, as it was impossible to go further, they stopped there for the night, and turned out the mules to graze. "Our position," says Dr. Grant, "was one of the wildest possible, awakening emotions of awe such as are inspired by a storm at sea. Yet there was nothing to fear. The place was too desolate and unfrequented even for robbers; but God seemed present in his matchless works. The very silence scemed full of God. It was a delightful thought that He was our guardian: in his presence was fulness of joy. A morsel of bitter barley bread, seasoned with the sorrel that grew around us, allayed our hunger. I lay down, and gazed silently on the dark mountains towering over us, and the starry sky that seemed to rest on their summits; and when sleep stole over me, it was sweet and refreshing as on a bed of down."

Dawn found them on their way again, and two hours' elimling along the mountain brought them to Alson, a place containing about one hundred houses, the first of the fifteen villages of Jelî. After breakfast they preached to the assembler villagers, and 
then hastened over the intervening ridges to the larger village of Zrany, where they spent the heat of the day in the same manrer. They stopped for the night at Mar Ezeich, and on the way had an illustration of mountain-life quite characteristic. Long ere they were near enough for the villagers to distinguish friends from foes, their watch-cry echoed from cliff to cliff, till, in a few moments, the most distant shepherds caught the sound, and came ruming, rexdy armed for the fight. One band hurried to eut off their retreat, another waited to dispute their approach. But, as soon as Dr. Grant was recognized, the counter-watrhword flew as fast, and all was quiet as before. It explained the way in which they sometimes estimate distance, saying one place is so many guns from another, - that is, the ristance at which the report of a gun is distinctly audible, as the alarm is three discharges in rapid succession, answered by the same number, to assure the first he is heard, and spread the alarm to the next. This custom Dr. Grant had occasion to observe afterwards in circumstances much more exciting. The present state of excitement was occasioned by the violence of the emir, who had seized one of their caravans on its way from Aleppo, confiscated the mules, and held the men as hostages for the payment of a tribute he dared not otherwise collect. It seems the men were prisoners in the castle of Julamerk while Dr. Grant was there, and allowed barely enough of bread and water to sustain life. He now longed to deliver them; and, finding a way of making his wishes known to the emir, without compromising his political neutrality, he happily effected their release. The matter, however, occasioned a state of feeling unfavorable to the object of his present visit; and the absence of many of the men, who had gone to convoy a caravan, with grain, from Gawar, still further interfered with his plans. Iet, the bishop of this tribe having died since his visit last year, he had the pleasure of inducing his intended successor, still in his teens, 
to go to the seminary at Oroomiah. He also distributed some books, and made additional arrangements for schools.

His route through Bass was the same as last year; but a blood feud prevented any of the men of Jelu going with him. All communication between the two districts was cut off. The bridge had been demolished, several killed on both sides, and some of the villages of Buss destroyed. He labored to restore peace, and not in vain; for negetiations immediately commenced, and in less than two months the whole matter was amicably settleal. Mis stay in Bass was short, but his reception cordial. The sight of many blackened rins, burned in the recent quarrel, furnished a fitting text for his earnest exhortations to peace and harmony.

He rested for a while at the summit of a mountain-pass, gazing on one of those apparently boundless views, that present new heauties the longer you look. The women in a zozan near by offered him sour milk from their goat-skins; but, on learning that he had the singular taste to prefer sweet milk to the acrid mess, they milked a sheep for his special accommodation. Not far from here he crossed a glacier, and, after sleeping on some dry fennel in the cleft of a rock, in another zozan, returned to the emir, after an absence of only four days.

A canopy of boughs, inferior only to the emir's, was provided for him and the bishop; hut so small there was barely room to lie down, and so low they could stand upright only in the midMe; and yet it was better than hundreds of Nestorian families occupy for half the year.

Every evening all the chiefs dined with the emir, and $\mathrm{Dr}^{\text {. }}$ Grant found no occasion to desire a higher seat; for, as usual, he sat next to his host. The attendants stepped freely upon the table-cloth, in bringing in and removing the several courses. Martial nusic accompanied the repast, though not the most enchanting; and often a mock combat, between two soldiers, armed with sword and shield, varied the entertainment; - for, 
while Persians love games of chance, the Kurds are more fond of manly sports. Hunting and feats of horsemanship are favorite amusements, when they can find room for them in their rugged mountains.

The monotony of the camp was relieved by the occasional arrival of recruits, who were sent on immediately to Amadia; and it is painful to record that some Nestorians from Tehoma were rewarded with cheap articles of dress for several ears of Turks they brought to the emir.

Finding he was likely to remain here for some time, Dr. Grant obtained leare to go to Tyary. Not, however, till the emir had urged him to give up his plan of building there, and come and live nearer to himself. When he pleaded that this would involve much inconvenience to his ascociates, and derangement of plans, he then requested him to defer building till he should see him again, to which the doctor readily assented. A sufficient reply, by the way, to the "hypothesis" that "under the guise of friendship for Dr. Grant he sanctioned the building of a missionhouse, which he hoped eventually to turn into a castle."* On the same page of the came work, the casual remark of a Nestorian about digging a well in the mission-house is made to bear the burden of the sweening conclusion that " the Nestorians generally looked on this building with suspicion." Such a huge structure erected on so slenter a hasis, and a hypothesis without any basis, show how little presented itself, on which to found insinuations against Dr. Grant.

Leaving a supply of melicine with the emir, and directions how to use it, Dr. Grant proceeded, Arogust, 9th, to Gunduktha, three hours distant. The people there had not yet dispersed from evening prayer; and, with the aid of the bishop, he endearored to explain and enforce the seripture they had just read. Supper was provided in the house of the steward of the church, and

* See Nestorians and their Rituals, vol. I. 1\&8. 
a fire was kept smoking all night to defend them from the swarms of mosquitos produced by their rice-grounds. The smoke was stifling; but, of the two evils, it certainly was the least. Priest Guwergis, who had imbibed some papal notions, on a visit to Elkosh, was now very unpopular; and after the invasion he went over to the papists.

Dr. Grant spent the next day preaching in the villages and making arrangements for future labors, feeling all the while that the people cared more for his medicine than for the truth they heard, and yet rejoicing in the privilege of proclaiming it to those who might never hear it again. In the end, they were very eager for schools and books; and again urged him to fix the station there, promising, if he did so, to bring all his fuel gratis, - no small offer, considering the distance they would have to bring it on their backs, - for, though there are many oaktrees near the village, the young shoots are cut off every year, and preserved for the use of their cattle in winter ; and, besides, Mar Shimon had anathematized whoever should cut one of them down, because they hold the snow around them, and keep it from sliding down on the village. Every year some are killed by avalanches, and men are often dug out of them, alive, perhaps, but maimed for life.

At six o'clock next moining, he began to climb the mountain in a direction west by north, for Tyary. Passing some shepherds, he saw one carrying home a sheep sadly torn by wild beasts, which he intended to kill, and preserve the meat in the usual manner. This is generally done later in the season, when they cook enough for the whole year, and, pulling out the bones, pack the meat away in jars, filled and covered with the melted fat, so as thoroughly to exclude the air. He saw another with its leg broken by a stone that rolled down the mountain from above; a danger to which the shepherd is exposed, as well as his flock.

The view from the summit was interesting, from the number 
of familiar localities in sight. Among them, Lezan lay west by south, showing that Tehoma was east, rather than south, from Tyary.

Further to the south he saw a smoke that filled the air for leagues around. It proceeded from the Turkish camp, some of whose outposts had been set on fire at the approach of the Kûrds. As the flat roofs of the country are thickly covered with earth, they always produce a great volume of smoke when burning. Dr. Grant thus expresses his feelings at the sight: "It made me long more than ever for the reign of the Prince of Peace. The very spot where I stood had witnessed many a bloody strife between two Christian tribes, that ought to have been cre in love. May their fate warn nations who, with clearer light, yet run in the same road to ruin! Even churches might learn to cease contending with each other, and unite their strength against the common foe. Surely there is enough to engage the whole force of the church, without one bickering word, from this time forth. We need union in action for the conversion of the world, rather than mere union in name or organization."

A short descent brought him to Bealaita (upperhouse), whose forty houses seemed to adhere, one above another, to the sides of a ravine, so narrow as to leave barely room for the torrent below. Though this was his first visit to this village, yet he was recognized by many former patients, who showed him every attention in their power. The use of the acrid contents of their dirty goat-skins compelled him to resort to aqua ammonia for relief; and, ere he could speak, the village priest had taken the skin from his mouth with an undiluted dose. It did not, however, stop his loquacity, for he rattled on as garrulous as before. Then one wanted medicine, and a dozen repeated the request; another must be bled, and ten arms were at once laid bare to the lancet. That was so bright, it was silver, of course. 'The brass on his umbrella was as certainly gold, and the rattans, were feathers. This incessant curiosity - and it prevailol 
everywhere - was at tmes fatiguing; but it was evillence of mind, however rude. Ile looked on them as unpolished diamonds, and felt that, by God's blessing, something would yet be made of them. Many thought they conferred a favor in receiving his medicine, as thus an addition was made to his stock of merit, and a passport to Paradise secured to him or his father. Their general plea, when asking for it, was, "Erwana 'd Ganokh," or "Erwana 'd Babokh" (charity for yourself or your father), and gratitude was expressed by "Allaha Katulch erwanokh" (may God write your charity). For all this, the doctor was obliged to them, if for no other reason, because it furnished such an excellent text for the preaching of the doctrines they most needed to know, - holding up Christ and his atonement as their only hope, and striking at their gieat error of putting forms and fasts and works of merit in his place.

Some of the villagers told him his mules could not possibly get over the road before him; but he had not forgotten his boyhood's motto, - "try," - and, taking additional help from the village, he kept horizontally along the mountain side, - for the ravine was utterly impracticable, - and, with the exception of some places where the aralanches had obliterated the path, leaving a smooth and steep slope to the very edge of the precipice, be dirl not find much trouble. At these places the villagers did admirable service; as some taking the mules by the head, and others by the tail, kept them from falling, till they reached a place where they could take care of themselves. Fatigued beyond endurance, the doctor rode, even where he knew it was dangerous, on the principle that additional exhaustion was the greater danger. He had a narrow escape, however, for his foot hit the rock and threw the mule off his critical balance; and, had he not instinctively leaped off on the up-hill side, and grasped a bush that enabled him to hold on to the mule, now trembling in every limb, both had rolled together to the bottom. It was not far from here that Dr. Smith, in 1844, had a still more nar- 
row escape. He was carefully planting his steps in the single row of foot-prints made in the clayey soil when it was soft in the spring, till, his attention drawn for a moment to something else, he slid on the smooth track of the aralanche, to the very verge of the precipice below. There he succeeded in grasping a shrub, and maintaining his hold till our attendants extricated him from his perilous situation. The writer will not soon forget the sight, or his feelings as he saw him arrested by the little bush, that God seemed to have placed there on purpose for his deliverance. Had he gone a few feet further, he would have been dashed to pieces on the rocks far below.

A night's rest, in a neighboring village, enabled Dr. Grant to go on next day with renewed vigor. His host was a former patient, who delighed in this opportunity to show his gratitude. His whole demeanor, too, pointed him out as one of the few who rose above the low level of general intelligence, and was prepared to appreciate better things. He manifested much interest in the plans of Dr. Grant for the good of his people. The latter was now in a most inaccessible part of the mountains, but, as the last road seemed always the worst, so the scenery just passed had always some prominent feature to distinguish it from previous views. The names of the villages here - Kasrueta (fort), Matha 'd Kasra (village of the eastle), and Lagippa (care) - illustrate the adaptation of the region for defence. In one place, to-day, Dr. Grant crossed a land-slide that filled the ravine, for some furlongs, to the depth of several fathoms. The people, shut in from all the world, know no language but their own; and, unlike the men of Jelû and other places, few ever look beyond the rocky ramparts that narrow the horizon of their native village.

Crossing another mountain, next day, he eame to the Zab, and stopped at a hamlet, where the people brought him very good figs and grapes, the first he had seen that season. Continuing up the river, now at the water's edge, now clambering over the 
high diffis that jut out into the stream, he reached the celebrated church of Mar Sawa. Stopping at a bridge just below it, he sent word of his arrival to Heiyo, the chief of the distric: and pronounced by Dr. Grant to be "by far the worst man he had known among the Nestorians." It was he who tried to rob Mr. Ainsworth and his party; and it was to avoid him that the doctor was sent round by Ashitha, on his first entrance, in 1839. As he was under the anathema of Mar Shimon, and regarded as an outlaw by all the people, he had hitherto avoided him; but now both necessity and policy led him to throw himself on his hospitality ; for, if mission families were to reside at Ashitha, it would hardly be safe to have such an enemy so near and unpropitiated. He was shown into an arbor by the side of a pool, fed from a mill above, to await his coming. While here he tried to make the acquaintance of the women and children, and two or three of the roughest-looking men he had seen, who stood by, apparently ready for any deed of villany. At length the outlaw himself appeared, - a spare, sinister-looking man, of about fifty yuars of age, with a face marked by intemperance, and still more with misanthropy. Says Dr. Grant: "I introduced myself as physician to the emir, with whom he has sided since the anathema. But, when he found I was on my way to Mar Shimon, he drew down his shaggy brows with a peculiar frown, and asked if I was not connected with the Franks who passed there two years before (Mr. Ainsworth and his party). Happily the emir had informed me of a chronic complaint which troubled him, and it was not difficult to satisfy him that I was really what I professed to be. This seemed to make a favorable impression. But, as I insisted on total abstinence as the only condition on which I would attempt his cure, another difficulty arose; and, without any result more satisfactory thin my own personal safety, I left, promising to see him again."

Having introduced this character to the reader, let us briefly relate his subsequent history. Dr. Grant redeemed his promise 
by several subsequent visits. On the first of them he spent the night with him, and says of it: "At first he received me in a very surly manner, and even hinted how easily he could rob and then despatch me with his dagger, at the same time drawing it from its sheath and passing his fingers along the elge. Some of his attendants also boasted of the numbers they had murdered, and their looks certininly did not belie their words. But I felt persuaded that, however they might waylay me in the mountains, I was in no dinger here. So I replied that, as I wats his guest, he could do with me as he pleased. But I felt deeply concerned for him and his people, who were drawing down the wrath of God upon them by their sins and animosities, and it would not be strange if they were all delivered to their foes. He pointed, with a sneer, to the rocky ramparts around, and asked how they could seale them. But I had touched a chord in his heart that responded to the touch; and though at first he declared he would sooner turn Moslem than obey the Patriarch, he gradually relented, and in the end was restored to the church. The anathema that had rested on him for years was removed, at the feast of the cross, in September, and Heiyo himself walked some miles to meet the Patriarch, and make peace with the Malek, with whom he had long been at war. Mar Shimon came in person and re-consecrated the church, which, from its central position and hoary antiquity, was held in great veneration. Many thousands, from all parts of the tribe, joined in the festivities, and I was weleomed by Heiyo with the cry of 'Hoba! hoba!' (love), about which I had spoken to him so much and so earnestly." Poor man! he has since gone to his account, with hundreds of those most joyous on that festal day. Whether his reconciliation with Mar Shimon had anything to do with it may be difficult to say. But he was among the first to fall, in the fatal invasion of 1843 .

Dr. Grant never interfered with politics; but he helieved Christ when he said "Blessed are the pearemiker:" "lie 



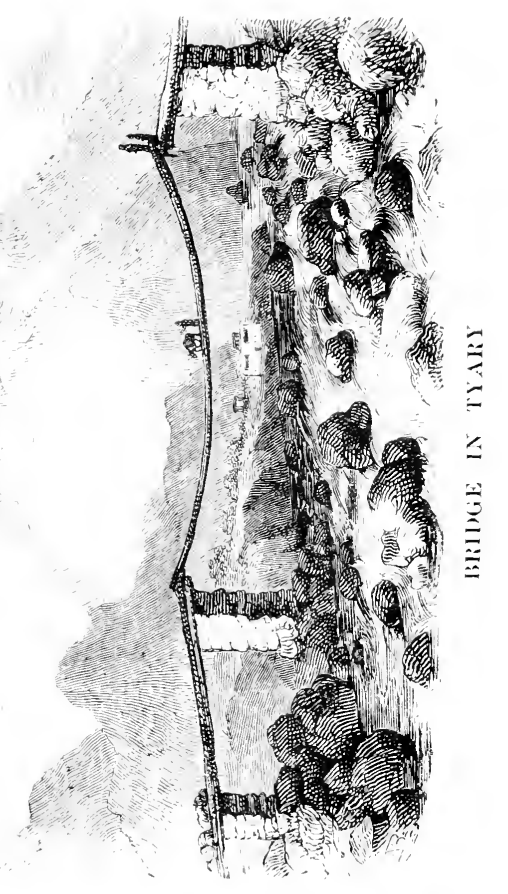


Kûrds sought to divide and weaken the Nestorians, and were even angry with him for thwarting their endeavors to do so; yet these words of his Saviour controlled his conduct, and humself has left it on record, that on no acts of his life did he look back with more satisfaction than on his efforts to ineulcate among them that love that would have made their rugged vales a paradise. But, to return to the narrative:

The little party, though refused a guide, on account of the feur referred to between Heiyo and the Malek, continued on alone, over debris from the erags above, that extended into the very river. Scarce a particle of earth was mingled with it, and the feet of the mule often slipped down so far between the stones that the rider had to step off - not dismount - to let him rise. A honse stood here and there on a narrow terrace, redeemed, with great labor, from the general desolation, and watered by well-built aqueducts, that, eompared with the little plot to be irrigated, often seemed disproportionately long. The terraces, small as they were, needed continual care to defend them from the falling rocks, that, else, would soon obliterate them altogether. Not more than one part out of two hundred and fifty is arable, through the whole of the mountains.

The bridge at Chumba, which they crossed, - one hundred and fifty feet long and three wide, and about twenty feet above the water, - was a grood specinen of their structures of that kind and may be better understood from the accompanying engraving than from any description. The curvilinear piece in the middle, as well as that at each end, is formed by the trunks of poplar trees, laid side by side, and covered with a web of wicker-work, instead of boards. The ends of the trees, wherc they overlap each other, are fitstened together with withes. To a stranger, the vihration of the narrow central part is truly startling. But Dr. Grant was most concerned for the poor mules, which had to be forced to the frightful passage, and then broke through the wicker-work several times, and had to be lifted up by the united 
efforts of sereral Nestorians. When Dr. Smith and Mr. L. passe up this same ralley, the only way they could get a mule across a bridge, higher up the river, after he had broken through twice, was to lay before him the rugs on which they slept, removing one as he stepped upon the other, and laying it down again before him, till he landed safe on the other side. The Nestorians often cômpel them to swim across, secured by long ropes, that keep them from being carried away by the rapid current.

It was night before they were fairly over the river; and, after supper, with his old friend, the Malêk, Dr. Grant mounted an arzaleh over the very centre of a torrent, the white foam of the water-fall breaking close to his head as he slept. He woke in the morning to find that he had kicked off his quilt into the stream, where it hung, fastened to the platform by one corner, undergoing a process for which it was all the better when dried. While the Malek replaced the shoes torn from the feet of the mules by the stones the day before, - the doctor carried a supply for such emergencies, - his kind-hearted hostess had a fine dish of rice and buttermilk boiling over the fire. This was something quite beyond their ordinary fare, and they watched its bubbling with bright anticipations; but, alas for the vanity of human hopes! the earthen pot - iron ones are unknown, and copper is too dear for the mountaineers - broke, and emptied all its contents into the fire. The good woman, however, was not discouraged; and some pottage of lentils, - such as Jacob sold to Esau at so dear a rate,_prepared in a newer ressel, afforded them a weleome repast.

Though late in the forenoon, the sun was just peeping over the moun'ain as they set out for the zozan of the Malek, whither most of re rillage had already gone. 'Two-and-a-half hours above Chumba they turned into a ravine at right-angles with the Zab; and, after three hour's' journey over a path no better than yesterday's, they reached the place. "The camp," says 
Dr. Grant, "was one of the best, and yet miserably poor; for I never had romance enough about me to gild the rude hut of hranches which forms the family mansion, the coarse felt which serves for bed and chairs, or the greasy goat-skin table, and dirty wooden bowl, which represents the whole china-closet of better homes; - especially when the last is filled with acid buttermilk-soup, and that eaten with millet bread, beside which ryc is a luxury and maize most excellent."

The only tent on the ground was occupied by Mar Shimon, and served at once for council-room, chapel, parlor and bed-room, - indeed, everything but retirement. The doctor was gratified by the kind reception given by the Patriarch to the New Testament, Psalms, and other books from the mission press. The reading of them formed almost the only religious exercise on the Sabbath; for, though they did not work on that day, the care of their flocks went on as usual. Some letters from Mar Yo. hanan, then in this country, were read alond by the Patriarch, giving a very good account of its religious character, and general superiority to his own. As for Dr. Grant, he was too ill to attend to anything but his own aches; for his damp dormitory at Chumba had brought on a swelled face, which was relieved only by a desperate plunge of his lancet into the very roots of his teeth.

Next morning he set out, with Mar Shimon, for $\boldsymbol{\Lambda}$ shitha, who was going to meet Suleiman Bey and Ismael Pasha, fully determined not to join them against the Turks. He regarded it as a strife between them and the latter for supremacy over the Nestorians; and, of the two, he preferred the success of the Turks, as the more responsible. Probably, also, he had the secret hope that, in that case, Christian powers would do more for their protection. Had he done otherwise, he might have made peace with the emir, aud thus had hut one eneny to combat; but, having received friendly letters from the Pasha of Mosul, he thought gratitude for present neutrality would make them firm friends 
in the futme. To this the doctor could only listen in silence. He says of it: "The pacific nature of his plan was at least commendable: and, on the principle of following peace with all men, I afterwards recommended him to be reconciled with the emir, and thus, if possible, avert disaster. I also tried to persiade the emir to peace with him ; but, further than this, I could not interfere, and had nothing to do with their political relations. Once before this I queried whether I ought not to advise submission to the Turks, to avoid a bloody subjugation; but that would involve taxation. and, most likely, oppression; and then I might be blamed, as having aided in bringing about such results. I therefore determined to 'know nothing among them but Jesus Christ and him crucified.' leaving all else to him ' who is wonderful in counsel and excellent in working.' This purpose I made known to them repeatedly and distinctly, telling them, in the very face of their cherished hopes, that 1 had neither political ends to serve, nor power to promote them if I had; and, though it produced a temporary disappointment, in the end it always secured their confidence and respect."

He was loth to leave the bracing air and grand scenery of the camp, then nearly eight thousand feet above the sea. When Ainsworth was there it was lower down. Malota - which he makes six thousand two hundred feet - is also far below it, and is a Nestorian, not a Kûrdish village, as he reports it. The people, as he passed, were busy collecting the Alpine plants they use instead of hay. These they pile in stacks, on the summit nearest the village, and slide them down in winter, on sledges shaped like a trough, with more than railroad speed. In descending the mountain, Dr. Grant had to ride, as usual, at the risk of being thrown over the head of his mule, when the Patriarch and the rest travelled on foot.

At the foot of the range he stopped at Galitha, subject to the Malek of Chumba, though inhabited mostly by Kûrds, and spent 'he afternoon in pleasant intercourse with Mar Shimon and the 
villagers. After evening prayers, which the Nestorians always finich before sunset, came supper; and, that over, Dr. Grant spread his rug on a high rock in the middle of the stream, and slept soundly on his flinty couch.

They crossed with ease, in the middle of August, the stream Mr. Ainsworth found so difficult in June, - so great are the changes in these mountain torrents. This also accounts for his mistake in making the Berdizani as large as the Zab. Dr Giant has found it almost as large, and again, later in the sea son, not one-quarter the size. The journeys of subsequent trav. ellers prove that the Berdizawi onght to be struck out of $\mathrm{Mr}_{\mathrm{r}}$. Ainsworth's map, and both that and the Habor laid down as in the map of Dr. Grant. After passing over several deep bank. of snow, they were four long hours in reaching the summit, behind Ashitha. Most of the party had to climb the greater part of the distance on foot; but, once at the top, they rested ralf an hour, enjoying one of the most extensive views he had sver seen. Here he took the following bearings with his pocket compass: Ashitha, at his feet, south-west by south; Amadia, due south, - the road over the pass distinctly traceable; Zacho, westsouth-west (this was afterwards verified by counter-observations); course of the Gara range, south-east; Sinjar, straight over Ashitha ; great bend of the Zab, east-south-east; Julamerk and Sillee, north-east; Liehun, north-north-east, in a valley running south to the Zab; Hertûsh, north-west; Chumba, north-east by east; zozan of the Malek, north by east; Tehoma, south-east by east, and east-south-east; Jclî, east by north; and Kawitha, south-south-east. These bearings, taken with a very delicate compass, will be found generally to agree with the original map of Dr. Grant; but some of them - as, for example, Zatcho, west south-west, instead of north-west by west - not at all with $\mathrm{Mr}$. Ainsworth. The latter, though full, is not accurate. His distance of Ashitha from Amadia is too little by half, while from Van it is altogether too great. Thus nuch Dr. Grant. The 
writer woukl arll, that, in company with Dr. Smith, in 1844, he was thirty-forr and three-quarter hours from Nosul to Nshitha, - exclusive of stops, - and yet, according to Mr. Ainsworth, they only made thirty-fire minutes of latitude. Again, we were seven hours from a point in the road, north of Madinki, and east of Kumri Kala, to Ashitha, and yet his map would show that we spent all that time in travelling three or four miles. At Julamerk we were told that a man could go over the mountains to Van in three days, and to Mosul, via Jezira, in five; though any one, from Ainsworth's map, would rather think of going to Jezira via Mosul, so inaccurately are the places laid down.

From Ashitha Dr. Grant learned it was three and a-half days' walk to Shakh, a large village in the country of the Hertûsh Kurds (he afterwards travelled it in three), and thence two and a-half to Van, and three to Julamerk.

At the bottom of the steepest ascent the party were met by a priest with a burning censer, which he swung before the Patriarch till they reached the village. As they approached, the crowd that came to salute him contimully increased, till their progress became so impeded they were glad to turn into one of the first houses they reached; and there Dr. Grant remained for nearly a week. Its situation was romantic. A stream from the snow in plain sight in the ravine above turned a small mill, the mill-stone, as usual, revolving on the same shaft to which the water-wheel was attached below. Released from service there, it dashed rapidly by the door, near a hower erected under the shade of at walnut-tree, for the accommodation of their guests. Here the doctor spent his time in quiet, a mile distant from the centre of the village, that now presented the appearance of a ramp. Four humber Kûrds had assembled there. The hear men of Tyary hat met in council, and many of them farored the Iroposal of the emir. Mar Shimon, however, firm to his purpose, managed to induce those opposed to his views to append such conditions to their coöperation as the Kurds would not 
accept, and tis all continued neutral, except a few, who went on their own zesponsibility. All this while, the Patriarch and Malek secretly corresponded with the pasha; and had they then induced their people to side with him, would have secured the most favorable terms. But, failing in this, they lost the favor of both parties. Of the pasha, because afterwards their help was not so much needed, as their subjugation was for his interest. And the emir, now exceedingly jealous of Turkish influence, hated Mar Shimon more than ever, for his correspondence with the pasha.

After the danger was over, the latter, instead of thanking. them for their neutrality, censured the few enlistments from Tyary, and the more general one from Tehoma, as a breach of faith. But to return to Ashitha. The Nestorians on whom the Kurrls vere quartered, finding they still remained after the decision, wished to drive them away by force, and some even sounded the war-cry; so that, for a while, all was confusion, till Mar Shimon interfered, and quiet was restored. In the confusion, however, four or five mules of Ismael Pasha were secured, by the orders of the Patriarch and Malek, and never restored till, with all else, they were lost in the invasion.

$\mathrm{U}_{\mathrm{p}}$ to the time of the departure of Ismael Pasha, Dr. Grant had not gone near the assembled chiefs. But Suleiman Bey and Tatar Khan, a Mertûsh chief, remained some days longer, and, at their repeated solicitation, he paid them a visit. The former received him a : an old friend. To the other this was his first introduction, and a was glad of the opportunity of forming the acquaintance of his nearest, and therefore most dreaded Kûruirh neighbor. His castle is distant only one day's journey, on the banks of the Habor. He hibself was exceedingly rough, even for a Kurd, - short, thick-set, with a large neck, and a face anything but preposcessing. His manners corresponded with his looks. He wanted to be bled, but, as usual, must first see the operation performed on another. And when, for the first time 
in his life, :e saw it done, with a significant shrug, he cried, "Kanj neena, - kanj neena!" (not good, - not good). The merciless robber, who had shed the life-blood of many a man, shrunk like a coward from losing a drop of his own.

The character of his tribe is in keeping with his own. They are a terror to the weaker clans about them; and woe betide the traveller who falls into their hands! But for his relation to the emir, Dr. Grant had not passed through their territory so easily in 1840. And, therefore, thongh the chief invited him to visit them now, as there was no missionary work to be done there, and it would have been quite in eharacter for them to rob him on his way back from enjoying their hospitality, he wisely declined.

On the 22d of Angust, he removed to the room usually occupied by the Patriarch, near the church; and, though political discussion erowded out all other topies, he labored faithfully to impress them with a sense of dependence on God, and the need of turning to Him in order to escape impending judgments. In the room there was as much freedom of speech among the people as any republican could desire. Though each, on entering, kissed the hand of the Patriarch, on bended knee, he often found it difficult to maintain his authority, or even command respectful treatment; and yet his power of anathema, outlawing the offender from society, and depriving him of Christian burial, keeps all in perfect submission. Many, however, deny his right to use this power, except for ecclesiastical offences.

It is remarkable, that while small villages have often two churches, and Minianish no less than four, this, the largest of all, has only one. That one, however, has no less than thirteen priests an thirty deacons; and formerly the number was much larger. With the sanction of Nar Shimon, Dr. Grant opened a school with thirty pupils, and one of the priests taught it up to the time of the invasion.

The size and salubrity of this village had first led him to select it for the mission station; and, on mature reflection, he 
now resolved to comply with the Patriarch's adrice, and make it such, at least for the summer. It is easy of access from Mosul, but fuel has to be brought a day's journey on the backs of men or mules. Mar Shimon was desirous that Dr. Grant should begin at once, while he was on the ground to aid hin. and offered to make each house furnish one of their tallest poplar-trees giatis, for the roofs. But he at once objected to all compulsory measures, and preferred deferring the whole matter till he had got the written consent of the emir; not that he had a right to interfere, but, as a matter of policy, to avoid all cause of complaint. Moreover, he had promised to do nothing till he had seen him again. These things show how ontirely erroneous is Mr. Badger's assertion, that " Dr. Grant informed him, before his death, that, on asking leave of Mar shimon to commence the undertaking, the Patriarch referred him to the emir, pleading. at the same time, that he had not the power of granting lis request." * The emir was then in Chull, a small Kirdish district, south-east of Tyary, and thither Dr. Grant resolved to go and see him.

On Friday, August 26, he took leave of the Patriarch, and. with the bishop and Baho, followed down the Izany toward the Zab. This stream rises in two large springs, on either side the valley; and each turns several mills before they unite below the village. With the exception of another in Jelû, Dr. Grant says he never saw fountains so large. The upper of these springs issues from under the base of the mountain, on the southern side of the valley, nearly opposite the site of the mission-house, and discharges a volume of water sufficient to supply the Ciroton aqueduets at New York twice over. Two hours brought them to Zawitha, in a hollow on the south-west side of the valley; and one hour further to Minyanish, with its four churches, one of which, at a little distance from the rest, Mr. Ainsworth calls the 
village of Cmra (chmreh), ais thotgh the word were a proper name. Lezan, the next village, is so low and warm, that two crops in the year, of either barley, rice or millet, are very common. With Kasha Iinel, of Minyanish, he found a copy of the history of the Nicene Council, by Theodorus of Mopsuestia, now in the mission library, at Beirût. The other works of that wr.ter he looked for in vain. This priest, next to Kasha Auraham the most leamed in Myary, was, hy the effortis of Dr. Crant, so far refomed from intemperance as to be intrusteil with the care of the sehool establithed in his village, till the war came, and eut of both teacher and pupils. At lezan he spent the night with Kasha Kcna, who accompanied him to Ashitha on his first risit, and ever after proved an efficient helper, teaching and preaching with more than common fidelity.

Next morning, in company with his host, he kept down the west bank of the Zab, over the mountain, toward the camp of the emir; passing the village of Zarne, with its forts strongly built with stone and lime. Turning thence to the Zab, he came to another fort, near the point where the Bey of Ravandooz was driven back, in 18.84 . Thence he tumed up the river, to a ford, where he crossed with difficulty, though the water was then shallow; and, scrambling up the opposite mountain, reached the camp of the emir after dark. Part of the way was so difheult that his mules sometimes slid ten or twelve yards at a time on the smooth face of the rock, and once or twice were in danger of sliding into the river. He was assigned a hut just vacated by Ismael Pasha, who had gone to Anadia. As the emir was ill with the ague, he was not an unwelcome guest; though his patient was more than usually cautious in taking medicine, as if he feared the doetor was in league with the Patriarch to take him off by joison. Even on ordinary occasions, both here and with the Patriarch. in serving eoffee, the attendant first pours a little into the chiel's cup, and then ont of that into all the rest, and drinks it himsell, before he pours fur any one else. 
On the Sabbath, besides many calls from Kurds and Jews, he assembled the Nestorians, for religious instruction, under a large walnut-tree, the bishop assisting him as usual. Next day, the men of Tehoma returned, half famished, from the war. For several days, so poor was the emir's commissariat, they had subsisted entirely on fruits and roots. The Kûrds soon followed, and thus the whole expedition failed. The doctor, meantime, had secured the written permission of the emir to proceed with his building, and was all ready to return. The camp was in a most healthy location, near the summit of the mountain, with the best of water boiling up from a spring in its centre. Yet, on account of the famine, he was glad to get away, especially as the emir was so chagrined at his failure he could think of nothing else. First, he accused the leaders of cowardice; then laid all the blame on the chief of Chull, who was fined and deposed. Forty days afterwards he went to Tyary; and, though the year before he had been active in burning the Patriarch's house, leagued himself with Mar Shimon against the cmir. He was very friendly to Dr. Grant, and invited him to his castle.

On his way to the Zab, Dr. Grant passed two considerab.e villages, and the descent occupied an hour and a half. In the first village of Tyary he was mistaken for a Kûrd, but, on being recognized, was treated with much kindness. The village priest, like many others of his profession, was absent with the army. They plead the necessity of giving the slain a Christian burial, but carry guns, and use them also, like the rest. They often wear the large dagger in their girdle, even at church; and this one Dr. Grant had seen before, not only with sword and dagger, but with a shaven chin, like the laity, - much more of an offence against elerical manners in these regions, where a man is not counted a religious teacher without a beard. Neithor Dr. Grant, nor any of his associates in Mosul, ever touched a razor while there, on the principle of a harmless conformity to the prejudices of the people. 
The Patziarch sometimes leads his army in person, as he did, the season before, against Berwer and Amadia.

At Lezan they hat to drive their nules into the river, and eross the narrow, erazy bridge themselves in their stockings, and almost on all-fours. Mr. Ainsworth was quite excusable in mistaking the structure for a bridge of ropes, - the long, bending poplar trees looking very like cables to one standing at a distance. Col. Chesney, who follows Ainsworth, and ignores the book of Dr. Grant, makes this mistake the basis of a general assertion that " the intercourse from sile to side of the Zuib is by means of rope bridges." *

Finding he could not build a house in Ashithat before winter, Dr. Grant hired one in Lezan, and spent some days in fitting it up, and providing forage and fuel, - wood he bought by the back-load, and straw by the basket-full.

On his way to spend the Sabiath at Zawitha he was saluted ly a discharge of guns, nearly two thousand feet above him. He replied by raising his mbrella, which called forth a shout of welcome. He employed the daty as usual, and was strongly urged by the villagers to locate the station there; but it was not at suitable place, and he returnod next day to Ashitha.

One of several ridges that there sweep down from the mountain, on the northern sille of the valley, continues on, with a geritle slone, till its romuled extremity overhangs the Izany, not fir from the fountuin in which it rises.

On this ridge, just below the village foot-path that leads to the upper cul of the valley, and overlooked by the terraces above, is one of the most beautiful locations the place affords. It is liot fir from the centre of the cluster of hamlets that form the village, though few of the houses are in sight, as most are concealed by irregular eminences on either side. The roar of the torrent is audible all day long, and through the night its deep bass, reëchoed from the mountain beyond, is as lond as it is

* Expelition to Enilnates, de., r. 12 . 
solemn and unceasing. The situation is salubrious, and commands, perhaps, the most pleasant prospect in that Alpine valley, hernmed in, as it is, on all sides, by overhanging mountains.

The beauty of the loeation had induced some village notable of former days to erect his eastle there, - a structure, probably, quite as much of a mansion as a fort. But the building, whatever it was, has long sinee disappeared. A stranger would not have suspected that the few shapeless stones that marked the site were anything different from similar stones covering the surface in all directions. I'erhaps some unneighborly attack convirced the ancient lord of the manor that his position was not so defonsible as it was heautiful, and constrained him to leave it for a safer location. But he had lived there long enough to give to the place the name of " the Castle," in the traditions of the village. Yet, in a region where every hamlet has its stronghold, and most villages have several, it never entered the mind of Dr. Grant that the name eould be an orcasion of alarm. Indeed, it would be difficult, in a country so aneient, to find any eligible lucation that had not been occupied in former years.

Dr. Grant, therefore, showed much good taste in selecting this site for the mission-house. Economy, also, was another motive. as we shall see by comparing the price of this with the sum paid for a much smaller lot immediately adjoining; for, while the latter was under enltivation, the grounds of the old castle were so hopelessly unproductive that they were left untilled, in a region where every available foot of land is cultivated with the greatest care. The title-deed for this, bearing the seals of Mar Shimon and Priest Abraham, may be rendered as follows from the Syriac :

"From the Patriarchal mansion receive ye prayer and blessing :

"Know ye who meet with this which we have written, that, in the year 2153 of the Greeks (era of the Seleucidr); Hekin 
Grant, the Englishman, from the country of America, came to the village of Ashitha, in Tyary, and bought the castle which is in the middle of Ashitha from Deacon Shlimon, of the house of Raban, and from Newiya, of the house of Dadeh, for the sum of thirty piastres [probably the same as the cherky, - about ten cents]; also, he bought from Daniel, and the son of his hrother, for the sum of thirty piastres; moreover, he bought from Iogannis, of the house of Bajeh, the piece of land which lies at the west of the castle, for the sum of twenty piastres; in the presence of Kasha Amaham, and Kasba Keiya, and Kasha Mattai, and Kasha Gynergis, and Kasha Isbak, and in the presence of all the priests, deacons and believers, of the whole of Ashitha. The lot of the munition of the castle is confirmed to Hetim Gaut, and to his associates the English of America, in the presence of Mar Yoosuf, Bishop of Adurbaijan, - that is, Anrny (pronounced Ûrmy).

"Moreover, the doctor and his associates, the English, shall dwell in Ashitha even until the resurrection, with the permision of the Emir, and the Nudebbir, and Mar Shimon Katolika, Patriarch of the East.

"Written by the hands of the unworthy Archdeacon Auraham, on Friday, of the sixth month of stimmer, in the year 2153 of the Greeks, in the upper room of the kalleita, of the church of Mar Gyûergis, in Ashitha. Amen."

That the Nestorians, even a year afterwards, thought no more of the old castle than Dr. Grant did, appears from the deed of an adjoining terrace, bought at that time for a garden, in which the building of Dr. Grint is called a house. The instrument, written on the same sheet with the other, is as follows:

" Know ye, de., that, in the year 2154 of the Greeks, Hekim Grant, with his English associates, bought a small field in front of his house, and joining it on the east, from Sepher, son of Aziz, 
for the sum of fifty piastres, in the presence of Mar Shimon, Patriarcha, and Mar Yoosuf, Episkopa, of Aurmy, and Kasha Auraham, and Kasha Mattai, and Kasha Denha, of Jeramon, and Sephoris, and Abdeeshûa, and Auraham, and Yoosuf, and all the sons of the village of Ashitha. Moreover, no man shall have power over Hekim Grant and his associates to take from them this field for ever and ever. Amen. The length of the field is eighty-two dhraa [cubits], and its breadth eight dhraa."

The opening sentence of the first deed, as it stands in the original, and the seal of Mar Shimon, are here subjoined.
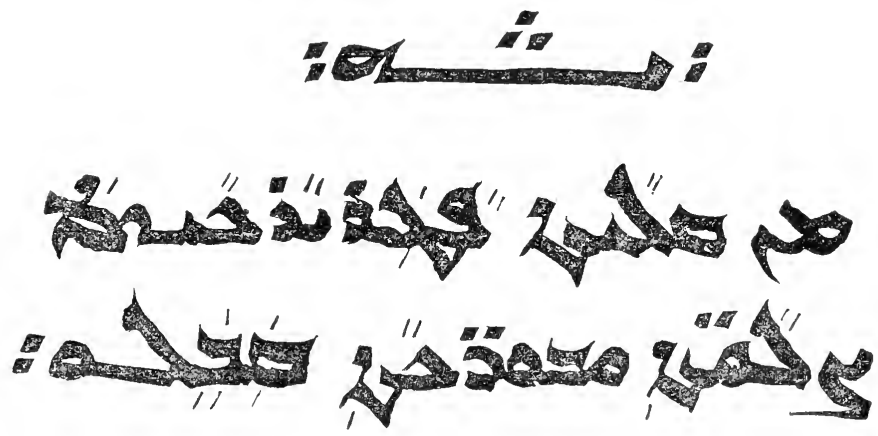

When these arrangements were completed, as Amadia had now submitted, and the whole country was so quiet, he sent Baho to bring in Mr. Hinsulale as far as Amadia, whence he proposed to escort him into Ashitha; but the messenger had seen so much of hard fare in the mountains

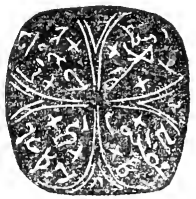
he could not be persuaded to return. 


\section{II A P T E R X IT.}

TISIT OF MR, GINSDALE TO THE MOLNTAINS - CONFERENCE OF PAPISTS WITH MAR : IIMON - RETURN OF MAR YOOSLF TO OROOMIAH - VISIT OF DR. GRANT TO JULAMERK - A SUNILSS WIXTER - INTERVIEW WITH THE EUIR - KÜRHSH LADIES - BANDITTI - THEIR WATS AND MEANS - RETCRX TO HOSLL - DEATII OF MR. HINSDALE-PLAN TO ASSASSINATE IR. GRANT- IIFH-CHURCII OPPONENT - HIS OWN STATENENTS - HOW REGARDED BY OTIER EPISCOPALIANS- HIS POLITICAL INELUENCE.

Os the last day of Deptember Mr. Hinsdale started for Ashitha, and, passing through Amadia, arrived there in safety, Oct. 7th. Dr. Grant met him about fifteen miles from the village. The joy of that meeting I will not attempt to describe. For the first time in four years the one enjoyed the society of a Christian friend, in this scene of hardship and danger. The other at length beheld the long-desired field of future toil, and hope whispered of many happy years of "fellowship in the sufferings of Christ." Mr. Hinsdale was very favorably impressed with the appearance of the place and the prospects of the mission : and all, from the Patriarch to the common pcople, received him with the utmost cordiality. "For this," says he, "I was indebted, under Gorl, to the rery favorable impression made by Dr. Grant, who seems to possess the unbounded confidence of all classes. Several told him that they had received him as one of themselves; and, now that I had come, they should receive me as himself." The good missionary expressed the wish " to live and die amons them," and the response was, "that is what we alson desire." Writing home a fortuight after his arrival, he says, "I have carefully examined whether Dr. Grant might 
not have given too much prominence to this field, or represented it in too encouraging a light. But I am eonstrained to say that, if he has erred at all, it his been in not pressing its claims with sufficient earnestness." They spent the month of October in mutual prayers and labors, till the papal Bishop of Elkosh and a priest from Rome, who had tried, but in vain, to precede $\mathrm{Dr}$. Grant, by entering from the Turkish frontier, arrived at Ashitha on the 27 th. They brought a present to Mar Shimon, and wished to remain till a larger one should arrive, then, as they sairl, at Diarbekr, on its way. He had an interview with them, in the presence of a large assembly; Mar Yoosuf, who had come with Dr. Grant from Oroomiah, being present with the rest. The arguments of the papists were met with much force and scriptural simplicity. Mar Shimon claimed equality with the Pope. One of the priests said, that if mere succession to the chatir of Peter gave power to the Pope, then the Sultan, who sat in the seat of Constantine, was entitled to the spiritual prerogatives exercised by the latter over the churches in the East. The Patriarch openly commenrled Dr. Grant and his associates, as the best Christians in the world; because, unlike the papists, who follow the word of the Pope, they took the word of God as their only standard of faith and practice.

The haffled papists had their presents returned, and were forbidlen to visit any other part of the mountains. For a time they delayed, under various pretexts; but, though they spared no pains in assailing both the character of the missionaries and their objects, they were eompelled to return, chagrined and disappinted. The people, meanwhile, showed a deep interest in the arrangements of $\mathrm{Dr}$. Grant ; though, as he says, the interest was not unmingled with marked and even violent selfishmess. Men of all ranks quarrelled with each other for employment in the severest drudgery. If he hired those who brought timber gratis, all were ready to carry heavy beams for nothing one day, for the sake of ten cents daily wages the rest of the week; and 
at one time so serious was the uproar, he had to dismiss the whole, retire to Lezan, and refuse to come back again till they were quiet. Mar Shimon then divided the village into sections, which were to furnish laborens in rotation. But this did not succeed in preserving order, Dr. Grant then took one from each honse in a section; but even then he had to let them know that he must be allowed to lahor in quiet, or he would cease altogether. Few men, beside Dr. Grant, would have dared to take such a stand, or, having taken, been able to maintain it. But hesucceeded to his entire satisfaction, though all he says ahout it is that "It was encouraging to witness how ready an untamed and lawless people were to submit. Though they knew we did not fear them, yet the protection of our persons and property must be ascribed, primarily, to the good hand of Ciod, for fatal assiults on each other are by no means rare."

The bishop had now become heartily tired of the mountains, and longed for his peaceful home on the plain. Though he had been fearless and tolerably patient, he had formed no attachment to the people. Nor is this surprising, since, for the first time in a life of filty years, he had been taken severely ill, far from home and friends. Yet, in communicating religions instruction he was faithful to the end; and it was not without regret Dr. Grant suffered him to depart, just in time to reach Oroomiah hefore the roads were blocked up, by the snow. Mis servant thel from hardships he could no longer endure. The hardy bishop followed in his footstejs. Yet the missionary, feeble in body but strong in spirit, remained at his post. In a letter sent by the bishop to Mr. Stocking he says, "We find an open door and a heari: g ear, but hard hearts, and a difficult though interesting lickl." In a previons one he had said, "There is no predicting the future here, and I know no better course than to go cn with our work, nithout regarding the wind or the clouds; and then, when a storm does arise, take shelter in the Lord, or whorever He directs." 
The Patriarch now returned to Chumba, and the departure of his much-loved associate to Mosul, just as Dr. Grant was recovering from an attack of ague, left him more solitary than ever; and winter had already mantled the mountains in white when he retired to his lonely house at Lezan. But scarcely was he settled there, ere he was summoned to the Patriarch. The emir had just returned from Badir Khan Bey, and report said har concerted neasures with him for the complete subjugation of the Nestorians. The men of Jelu had seized mules from the Kurts, to make good their loss. Mar shimon had retaliated some other injury in a similar mamner, and a report was spreading among the Kôrds that Dr. Grant was building a castle to defend the Nestorians. On every side the lowering clouds portended a storm.

The doctor set ont for Chumba, and on the way met a message from the emir, requiring his immediate professional attendance. 'The letter was short, but friendly; yet, the proverbial treachery of his race, and his own increasing hostility to Mar Shimon, led the latter, with the Malek, strenuously to oppose his going. But "Are they disinterested? Are they not still looking for political help, if not from me, yet in connection with me?" were the questions that arose in the mind of Dr. Grant. Still he felt there was real danger. Reports might have misrepresented him, and roused the jealousy of the chief. On the other hand, to refuse would incur certain enmity, and he feared for the effect on the prospects of the mission. This last decided him. It was now Saturday; and, after spending the Sabbath in seeking wistom fiom above, he preferred personal exposure rather than endanger the future prosperity of the nission. So, after trying to argue the case with Mar Shimon, and writing letters to Mosul on Monday, he set out fer Julamerk on Tuesday, Nov. 29th, amid mingled blessing and foreboding. His road was the same as in 1839 ; it is so bad that the people here earry their loads on their own backs rather than on mules - one nran taking about a hundred and fifty pound. 
Our boxes of books from Oroomiah had to be carried two or three days' journey in the same manner.

A Jacobite from Mosul was with him, instead of Baho; and hired mules supplied the place of his own, that had returned with Mr. Hinsdale. No degree of familiarity could divest the scenery of its grandeur. The stupendous cliffs excited new wonder, and the roar of the rushing river was by turns stumning and inspiriting, as before. At the mouth of the Berzawa (Berdizawi of $\Lambda$ insworth) the mountains were particularly grand. Towering up thousands of feet, they seemed like giant castles, now crowned with purest white, now mantled in the sunlit clouds. The place is thus described by his associate in 184t: "All around the walls of rock inclined at irregular angles; but directly opposite an isolated precipice towered up to a giddy height. Its form was rounded. Horizontal strata, piled up tier above tier, gradually lessened in size as they rose, till the eye grew weary in following them. It was one of nature's wonders, mocking the puny works of man. But, to appreciate it, you must stand on that low wall, amid the dashing spray, in a gorge so deep that the sun scarce reaches it at noonday; and, the view shut in on every side, you must see for yourself this castle of the mountains towering up before you in all its Titan regularity and grandeur."

Deep in the rocky glen of the Berzawa stood human dwellings that never see the sun during their long and dreary winter. It was curious to trace the limit of sunshine distinctly marked on the mountain above them, by the line that divided the bare earth from the snow below. All above it basked in the warm rays of a noon-day sun; all below was frozen hard, and so contimues till spring revisits the wintry abode. And yet, even with such deep, narrow chasms, - they can hardly be called valleys, - Dr. Grant never met with a case of goitre, or similar diseases, so prevalent among the Alps.

He stopped for the night at the small village of Derawa'd 
Walto, where an old friend assigned him a room, with hardly space to spread his rug, amid goat-skins filled with winter stores. He was making the best of his narrow quarters, when the head man of the village transferred him to a spacious upper room, whose open sides were partially closed with wicker-work and straw. A blazing fire in the middle of the floor was quite welcome, and a good supper still more so ; for there is nothing like the air of these mountains and the exercise of their roads to dispose a man to eat whatever is set before him, even though its quality be none of the best.

He had heard that the Nestorians and Kûrds were collecting for a skirmish on the road before him; but, as the only alternative was to pass through the country of the sillee Kûrds, who might not be very friendly, if the emir was hostile, he kept on his way, and next day, as the bridge was gone, erossed the Zab on some frail poles, resting on rocks about twenty feet above the water. After he had prescribed for the most needy of a crowd of patients, in the Kûrdish village of Dizza, his attendants led him out of the usual road, along a solitary footpath, to the very summit of the mountain. This was a device of theirs to avoid any ambush that might have been laid for him, and was carefully concealed, even from himself, till it was too late to turn back. The ascent was slow and toilsome; but, once on the top, the grand view of snowy mountains on every side amply repaid him. He kept along just under the rocky crest of the range, higher or lower, as he could best obtain a footing; and, at the extremity, found himself in sight of the castle of Julamerk, and amother, then in ruins, on one of the peaks of the same mountain on which he stood. It is appro. priately termed Kala El Hawa (castle of the winds); and, like many others in similar situations, has been deserted for another more accessible. Whether because the fiery spirit of their fathers burns less fiercely in the hearts of the present generation, or because their modes of warfare have changed, does not appear. 
He entered the castle of Julamerk just at dusk, and was led through iron-bound doors, and long, winding passages, to a vaulted room, assigned him by the chief. Exhausted and faint, he threw himself upon a rug in one corner, querying whether it were not his prison. He thought of the dissuasions of the Patriarch. "Why was I brought to this remote part of the castle, - this strange apartment I had never seen before?" But then it was neat and comfortable. Lights were soon brought ; and, ere long, the hearty welcome of many a familiar voice proclaimed " $\mathrm{All}$ 's well!" In an hour he was summoned to the presence of the chief. He found him in a spacious apartment of the harem, spread with rich Persian carpets, and ornamented with a profusion of arms and poreelain intermingled. The emir sat on a yellow satin divan, bolstered up with pillows of the same material. Ten or twelve of his chief officers, an uncle, and his cousin, Suleiman Bey, sat on the opposite sille of the room. He never seemed more glad to see the doctor, and expressed much gratitude for the trouble he had taken to come and see him. He said he had been quite sick; but, Al humdoo litlah (thanks to God), he hoped he was better, at the same time holding out his hand for the doctor to feel his pulse. That done, conversation took a wider range.

Emir. - Well, what have you been doing since we parted?

Doctor. - A part of the time I have been building, with the emir's permission.

Emir. - But I hear you are building a castle, - how is that? How many rooms have you?

Doctor. - Four, built of loose stone laid up in mud, no higher than a man can reach. A fine eastle, truly, that a man can pull down with his hands! And what is to defend it? Did you ever see me armed?

Emir. - (Turning to his council.) There, did I not tell you he was a true man?

The doctor learned, next morning, that when the report came 
the emir said, "I do not believe it; but I will send for him. If he comes, he is an honest man; if not, it may be true, and we must look into the matter." Then, turning to the doctor : "Well, I did not believe the story. But what are those large holes in the sides of your house? (The Nestorians have no windows in their dwellings.) They say they are dikkans (stalls or sl.ops). Are you building a bazaar?" He laughed heartily as the doctor drew a picture of a structure at once a fort without a gun, and a bazaar without anything for sale, and then resumed: "But why go away there? Come here, and I will build you a better house. You want to instruct the Christians. Very well; here are Christians, and more will come if you do." The doctor reminder him that his associates must be in the midst of the people. But the emir evidently wished him to be within reach, and that any benefit arising from his residence in the mountains might accrue to Julamerk. Supper was now brought in, and never was their fine pilav more inviting. Coffee followed, and the doctor had the honor of the company of the ladies for the rest of the evening. This he never had in Persia or Turkey; though he had once been privileged, as Hekim, to eat with a Persian princess and her husband, who was uncle to the Shah. But that was in the seclusion of the harem, and this in a promiscuous circle. Kûrdish women enjoy much of the respect accorded to their sex by the ancient Persians, especially mothers, who are honored according to the number of their children. In this case, the younger wife, though evidently a favorite, stood at a respectful distance, while the mother of the young chief had her place by his side. He too was there, and inquired after his little playmate Henry Martyn. Altogether, to the doctor it seemed much like home. Yet he could not but think how it would seem, when the emir is absent for months, at Bash Kala, with the mother of his eldest son and prospective successor ; or to her then two years absent from her husband, if the names husband, wife and home, may be thus desecrated. 
The ladies were adorned with a profusion , f ornaments, of massive silver, from the top of the kurs * to the tinkling ormaments on their feet. Their wrists were so loaded with bracelets the doctor found it difficult to feel their pulse. Their silk tunies were quilted so thick they might have stood alone. Tiney wore no veils; and nothing but a little artifieial coloring concealed their faces from the circle he met there day after day.

The chief was ever derising some new amusement. At gne time the doctor must read English, and, at another, teach him to do the same. His green-turbaned moollah, too, wanted him to show them how we prayed, and the doctor gave him a specinen of our preaching instead; - explaining the spiritual nature of prayer, and the solemm manner in which it became us to draw near to God; and asking how he, a religious teacher, could so make light of sacred things. All listened with attention; and the ehief approved, and added to this rebuke of his own elerical companion. Thus was Dr. Grant ever on the watch to do good, and so wisely could he speak a word in season.

During his stay the emir pronounced sentence of death or one of the highest local governors. He was then a prisoner in a distant castle, and thither half a score of his reckless robbers were immediately despatched. The doctor met them returning from the bloody deed, and could not but shudder at the edueation of these young men. They boasted to him of the number of murders and robberies they had committed. One of them had just plundered a caravan, between Mosul and Amadia. They go out in parties, and learn the intended movements of travellers, and then waylay them. The villagers dare not warn their intended vietims, lest they suffer in their stead; and henee the frequent choice of an unfrequented route, or a movement so rapid as to anticipate theirs.

Ismael Pasha, at this time, was in the eastle, arranging to

* A round disc of silver, sometimes of gold, worn on the top of the head. - See Lane's Modern Egyptians, r. 359. 
annoy the Pasha of Mosul through the banditti of Zeiner Bey, an ex-chief of Berwer, who ravaged the borders of the pashalie, for many months, with impunity.

Dr. Grant now heard no more of the alliance with Persia. Overtures from the Turks, through the Pasha of Van, and the original plan of subduing the Nestorians, were again on the tapis. Ile ventured to speak of peace; but the emir would hear of nothing but unconditional subnission. So he disclaimed all interference. The ehief evidently expeeted help, or he would have assumed a milder tone. It was said he had already matured his arrangements with Badir Khan Bey, and he was now in correspondence with the Pasha of Erzrum.

Dr. Grant made a hurried visit to the Patriarch's family in Diss, and saw the ruins of the house where first he met him. Now, how changed! The family he found in a neighboring village, living in comparative poverty. The ehief had then just inflicted some injuries, which they repaid next spring, with interest. This was more bold than prudent, when their very existence was in danger. He arrived in the evening, and returned to Julamerk next morning, when his ague returned with such violence that he was bewildered, and almost senseless. Medieine, aided by the motherly care of his old friend, soon relieved him. She again warned him against the wiles of the emir, saying, often, "Kermanj baebueht" (Kûrds are treacherous, or giaceless).

On the 7 th of December he left the castle, with a guide from the emir, and spent the night among the Sillee Kûrds, one of the smallest of the fifteen elans of the Hakkary tribe. Next morning he rose early, and ate a late breakfast with his Nestorian friends at the Zab. As the poles had broken, or been earried away, he had to ford the river below; but, once across, he felt a relief at being again among friends, and away from the treacherous Kurds. He was now, in his turn, the protector of a messenger from the emir, on his way to Mosul; and he was 
also glad to be able to secure the release of the Kûrdish mules the day of his arrival at Chumba, which he reached on the morning of the 9th, much to the joy of the Patriarch and friends. The night after he spent with Heiyo, who was now much attached to him.

On the 11th he returned to Ashitha, worn down by illness and fatigue. Providentially the snow was later than usual, or his way would have been cut off. He now only waited the arrival of his messenger from Mosul, to return and carry on his work in quiet at Lezan.

He had already written to Mr. L., Nov. 8: "I would fain come at once to meet you, did not other duties detain me here. Meantime, I send a living epistle in the person of our brother, who will tell you all that concerns our prospects, and how desirous I am to see you here, if possible, before winter. I will not dwell on my lonely situation as a plea for your society, though I have learned that, in these mountains especially, 'it is not good for man to be alone.' There are other considerations. . . . . I I hope that, howerer trying this may be to Mrs. L., on her first arrival in this strange land, she will cheerfully forego all personal considerations, for the cause of her Redeemer. I need not say how cordially I would welcome her at our mountain-cottage did not the lateness of the season, and our want of accommodation for ladies, constrain me to forego that pleasure till spring. Please present to her, and accept for yourself, the warmest assurances of the hearty welcome I now tender to you both in anticipation."

How this plan was frustrated will appear from the following letter to Mr. Stocking: "Mr. and Mrs. L. reached Mosul on the 12th of Norember, , ne day before the return of Mr. Hinsdale, who had refreshed me by a delightful risit of a month. He writes me, they 'are both suffering much from illness. Mr. L. has had a severe chill every day since his arrival, and the fever following it has lasted for several hours. Mrs. L., too, 
since last night, has been in nuch distress, though for the last two hours she has been more quiet, and has now fallen asleep. $\mathrm{Mr}$. Badger is here, and has commenced operations by assailing us. I have not yet seen him. He has brought letters from the Jacobite Patriarch to have the schools suspended, and that the people here take no books, either from us or from him. I have been told, confidentially, by the three leading deacons, that they have received a private letter from their bishop, telling them two sects were coming to Mosul, and charging them to beware, most of all, of Mr. Badger. They said, also, that the Patriarch's object was to prevent the appearance of favoring either party till the bishop should come and manage his own affairs. We have as warm friends here as ever, and the leading men are evidently much prejudiced against Mr. Badger, by the course he has taken against us." ",

But this was not the worst. Another messenger brought word - December 13 - that Mr. Hinsdale was dangerously sick. Constant and unwearied attendance on his sick companions, while yet suffering from a cold contracted in the mountains, had induced fever of a complicated and alarming type. His disease had already run two weeks. So, making what arrangements he could for the schools, next morning found Dr. Grant on his way to Mosul. His route through Dawûdia led him through the most populous part of Berwer, and he spent the night at the Nestorian village of Músekin. The chief of that part of the district was there, and treated him with much kindness; - a fact the more worthy of notice, as the Pasha of Mosul had reported at Constantinople a letter from this chief, complaining of his operations in Ashitha. The letter was afterwards ascertained to have been written, in the name of the chief, at the dictation of the pasha himself. Next morning he erossed Tûra Matineh, and breakfasted at Dawûdia, with the Turkish commander of the garrison. That evening he spent at Baadry, and rext morning struck across to Elkosh, famous for the tomb of 
the prophet Nahum, and the convent of Rabban Hormuz. The latter was then just as it had been left by Ismael Pasha, who destroyed the library, and carried off the monks prisoners to Amadia, where several were killed by torture before they were ransomed. The torture was inflicted to make them reveal a treasurs, said to be hidden in the convent. The village was sacked at the same time; and the whole charged to the influence of a young Chaldean, in the employ of Ismael Pasha, who was a near relative of Mar Elias. On the ground of this charge, the whole family were imprisoned at Mosul, and made to work with the convicts in the powder-mill, till, in the utter want of evidence against them, they were at length released.

Dr. Grant was treated kindly at Elkosh as a physician, if not as a missionary; and, hastening on, he reached Mosul early on the morning of the 17th, - only three days from Ashitha. But it was too late to save his lamented associate. His fever had assumed a typhoid character, and was complicated with organic disease, which, with the internal hemorrhage that supervened, closed his valuable life on the morning of the 26th, in the thirtyfifth year of his age. He had not been two years in the field; and yet, in this short period, he had shown rare qualifications for his work. After his death some of the leading Jacobites said to us, "If any of the saints are in heaven, Mr. Hinsdale is there." His end was peace. Throughout his sickness he evinced the most entire resignation. Even during his delirium, when Mrs. H., thinking he wanted some food, asked him, "Is there anything you would like?" he answered, "I should like to have the will of my heavenly Father done.-O, yes! I should like that!" It was his ruling passion strong in death. To do the will of God, and have it done by others, was his great object here, and still is in that better world whither he is gone. In all things he evinced a spirit that made us feel he was just the man we would have selected for our associate. Dr. Grant was allowed to be with him only ten days before he died, and deeply 
felt his loss. "O, what a loss!" writes he to a friend. "How and when it will be repaired, God only knows. A dear brother and faithful missionary has gone, and that at the very moment when his services seemed needed the most. I feel sometimes almost like breaking down under the weight of care and responsibility."

Mr. Hinsdale was buried in the court of the Jacobite church of Mar Toma; and his bereaved associates were grieved and astonished to learn, a few days after, from the people themselves, that Mr. Badger had translated for them what he called portions of the prayer offered at the grave, representing them as heathen; stating, at the same time, that we held them up to the contempt of Christendom in the pages of the Missionary Herald.

But, though unable to save Mr. Hinsdale from death, Dr. Grant arrived just in time to save his own life from the assassin. The pasha had written to the chicf of Nirwa to despateh him privately; but a watchful Providence kept back the letter from its destination till the intended victim was out of reach. His sudden arrival, therefore, was as surprising to the pasha as it was gratifying to his friends. But he received him with as much external kindness as though nothing had occurred; and the doctor was called on to attend him as physician, as before. It was part of an effort of the pasha to get rid of all European reporters of his evil deeds, and illustrates what has been already said of the difficulty the natives found in making known the oppression they suffered at his hands.

Mutran Athanasius left Mosul for India a few days before Dr. Grant arrived from the mountains, but not till he had sharply rebuked Mr. Badger for telling the Jacobites that the Syriac Bibles of the British and Foreign Bible Society were deficient, because they did not contain the Apocrypha; or, as Mr. Badger himself says, in his hook, "expressing regret that the Apocrypha was not published with thrm." *

* Nestorians and their Rituals .. 71. 
It will be difficult to write the biography of Dr. Grant, from this date, without giving some account of $\mathrm{Mr}$. Badger, who came to Mosul with the avowed purpose of opposing his mission. He was a young man of much energy and perseverance; the son of a pious widow in Malta, where Mr. Temple introduced him into our printing-office, then on that island. From thence he removed to Beirut, and labored some time in connection with the press of that station. But, becoming imbued with the high-church notions, - or, as it might be termed, the ecclesiolatry, so prevalent in some quarters, - he was sent out by the Bishops of London and Canterbury to testify the good-will of the Church of England to the Nestorian clergy, and render such assistance to them in the work of Christian education as they might approve. Besides this, he was to distribute the Bible and the English Liturgy, and collect ancient manuscripts, both in Syriac and Arabic, especially the scriptures, rituals and liturgies.

Mr. Badger might have done all this without pursuing the course he did. He need not have gone further than certain bishops in this country, who wrote to the Jacobites, informing them " that the church in the United states had no ecclesiastical connection with the followers of Luther and Calvin, and took no part in their plans or operations to diffuse the principles of their sects." But this was not enough for his ardent mind. He tells us in his own book, * that " the unwarrantable sectarian proceedings of American missionaries among the Armenians confirmed him in the opinion that he ought to hold no intercourse with them, and decided him not to return the risits which one or two of them obligingly paid him." One of these was Mr. Temple, already referred to. "In this act," he adds, "I did violence to my own natural feelings; but I had a duty to perform for the church." He justifies his course $\dagger$ by the charge that, " notwithstanding the wide difference between us, they (the mis. 
sionaries), designedly or otherwise, give it to be understood that they hold the same faith that we do, and differ only on the most trivial points;" adding, " this opinion has been so deeply impressed on the great mass of native Christians, and has becn so strengthened by the manner in which many of our own missionaries have fraternized with them, that $I$ have found is is most difficult task to persuade them to the contrary." It neer hardly be said that either he or "many of his oun missionaries" were mistaken. And if they were right, then as certainly be was wrong. If, ont of the "many of his own missionaries," and? "the great mass of the native Christians," he alone rightly discerned the truth, he might have pardoned those who fell into so general an error.

He then goes on to say, on the same page, that " the right which the committee of the American Dissenting Board" - I give the title as I find it - "arrogate to labor among the Lastern Christians is as ludierous as it is presumptuous; " and quotes the remark of Dr. Anderson, as an illustration, who says, speaking of Mr. Ainsworth's visit: "Some consequences have resulted from this partial interference that, of course, were not anticipated, but which show the importance of carefully avoiding whatever would tend to awaken the thought among the Nesto. rian ecclesiastics that there are rival Protestant sects and interests, upon which they may practise for the private gratification of araricious desires;" and then publishes a letter to the bishops who sent him, in which he says, * that as the Patriarch had written, saying that he had opened two schools, and wanted money, he informed " his Holiness" that, "though he preferred the priests who taught should be paid by him, yet he was not at liberty to place such large sums at his disposal;" and adds, "I have moreo ar requested his Holiness to inform Kasha Mendu (the messenger) where he has already opened the two schools 
mentioned in his letter, and have directed the Kasha to visit them before he returns, as I have some fear that he may mean those under the direction of the American missionaries, at Ashitha and Lezan. I may be mistaken, but I have my doubts on the subject."

On his arrival at Mosul, both he and Mrs. Badger were attacked with ferer, and he " records with gratitude the kint professional services of Dr. Grant, which he spontaneousty offered them during their sickness." But he does not tell that he commeneed the war even before he was able to leave the house, seeking to undermine his influence, and destroy all that he had accomplished through years of lonely privation and constant danger.

Dr. Grant knew his errand, and yet visited and preseribed for him as he did for his own associates; and often did he express his delight in the opportunity to show them kindness.

We have seen Dr. Grant leave the mountains, where he har designed to spend the winter, and hasten to the bedside of his dying brother. He intended to return, but various eauses conspired to detain him till April. The snow seldom disappears from the village of Ashitha till the month of May. But Mr. Badger hurried off in the middle of February; advanced on foot when his mules could press no further; slid down from the top of the mountain before Ashitha on the surface of the frozen snow, and had an interriew with Mar Shimon in the village. Of the character and object of that interview we are not left to mere conjecture. He himself tells us, * "The proceedings of the American dissenters necessarily formed a leading topic of our discourse. I did not fail to acquaint the Patriarch how far we are removed from them in doctrine and discipline. I showed liim, moreover, that it would be injudicious, and by no means satisfy us, to have schools among his people by the side of

* Nestorians and their Rituals, 1. 248 . 
theirs, and p. essed upon him to decide what plan he would pursue under existing circumstances." Lest any should think that his church sympathized with him in such a course, perhajs it ought here to be stated that one of her bishops, whose praise is in all the churches, has actually proposed sending another of their clergy to the Patriareh, to undo the mischief he occasioned; and an American missionary-bishop - Rev. II. Southgate - feit so ashamed of his proceedings, that, in a letter lated Constantinople, Dec. 6, 1843, he writes: "Mr. Badger assumed a position of violent hostility towards the American missionaries, and showed it in all his proceedings. I opposed this with my whole strength; and to it he owes all the trouble which has befallen him. The Society under which he acts never instructed hin to pursue such a course." *

His political infucnce during this visit was not much more favorable. While he was in Ashitha two messengers eame from the emir, desiring Mar Shimon to appoint a place where they might meet and confer on their differences. The Patriarch refused, and the Kûrds, both in Jezira and Julamerk, attributed the refusal to the advice of Mr. Badger. Dr. Grant wrote concerning this, just before his last sickness, as follows: "It was an unfortunate incident that the Patriarch's brother should say to the messengers, pointing to $\mathrm{Mr}$. Badger, ' $\mathrm{It}$ is just as these men say, - the country is theirs, not ours.' It could hardly fail to awaken jealousy of foreigners, as I have good reason to believe it did. Mr. Badger's influence, if he exerted any, should have been in fuvor of peace. But so it was not understood to be by the Kûrds." One of those very messengers said to Dr. Smith and Mr. L., at Berehulla, near Julamerk, in 1844: "I see you are very different from other Englishmen; for you wish to maintain peace with all men. But when I delivered

* See $\mathcal{N} e w$ York Observer, 1814, p. 27. See, also, on this topic, Layard's " Babylon and Nineveh," pp. 424-5. 
my message to Mar Shimon, in Ashitha, in the presence of Mr. Badger, as soon as it was translated to him, he recommended the Fatriarch not to seek the friendship of the Kûrds, but to apply for aid, if he needed it, to Fingland, which, he said, was able and willing to grant him the fullest protection,-and so the emir could not get the ear of the Patriarch." The Kaimakam (lieutenant governor) of Mosul, too, after his return from a conference with Badir Khan Bey, told Dr. Grant that the visit of Mr. Badger had been injurious, for that very reason. Still, even this coud not justify the report, circulated at the time, that Mr. Badger was the eause of the war; for the roots of that extended back much further; and no one can say that, even had he, like Dr. Grant, persuaded to peace, the result could have been averted.

About this time, also, the Patriarch, in his anxiety to propitiate the Turks, sent a force from Ashitha against Zeiner Bey, - another false move, that irritated the Kirds, and roused Zeiner Bey himself to a terrible revenge.

During this winter, Dr. Grant was busy, as usual, in doing good to all classes; and Mr. L., after his recovery, devoted himself to the aequisition of the Syriac.

March 24th, Dr. Grant wrote to his brother Ira, as follows:

"In England a party has arisen, in the Episcopal church, who are striving to effect universal union, by going back to the traditions of the fathers. They have sent out one of their emissaries to counteract our efforts, and prerent our 'sowing discord' by undermining the outward forms of these Eastern churches. In their estimation, the essence of all union is in a regular apostolical succession of the clergy, - that is, in episcopacy,_-and, wanting this, we poor dissenters are out of the way of salvation, while the Papists, with all their abominations, are acknowledged as brethren!

"I have been more particularly indisposed of late, and have written this upon my bed. But I am a little better, and lope to be able to set ont for the mountains in a very few days. 
In March Dr. Cirant received a letter from Mar Shimon, filled with oriental protestations of undiminished attachment, and a most urgent invitation to return to the mountains.

At the same time, the emir revealed his true character in sending a complaint to Erzrum that Dr. Grant was building a strong fort in the mountains; and that the people were so opposed to it, they rose on him en masse, and would have killed him, had not he (the emir) interfered for his deliverance, adding that he himself would have expelled him, but that, as the mountains were under the jurisdiction of Erzrûm, he preferred to await the orders of his superior. This glaring falsehood, fabricated after his repeated invitations to Dr. Grant to settle anywhere in the mountains, and his written permission to build in Ashitha, was repeated again the following summer.

By such a show of zeal for the government he hoped to secure its zealous coöperation with him in the overthrow of the Nestorians; an object to attain which he hesitated at no sacrifice of honor or of prineiple. He may have hoped, also, to attach Dr. Grant more firmly to his interests, by making him more entirely dependent on his protection. However that might be, Dr. Grant saw in all this no cause for discouragenent, and went on with preparations for his fifth annual tour.

\section{4}




\section{II $\Lambda$ P T E R X V.}

FIFTH VISIT TO THE MOUNTAINS - MUD VILLAGE - KHORSABAD AND $M$. BOTTA - AIN SIFNFH AND YEZIDEES - HEROINE OF BASTAWA - WOMAN IN MOSUL - NATURAL HISTORY - AMADIA - WIAT POYERTY AXD MISERY MEAN - PASS OVER IATINEH - SNOW - VALE OF BERWER - ZARNE - MULE-RIDING IN THE MOUSTAINS - PATPIARCHAL MANSION DR. GRANT'S CASTIE AS IT WAS- NESTORIAN FEAST - A NIGHT VISIT FRON KÔRDISH SPIES - A NESTORIAN STRIKE - HOW TO SLPPRESS IT AXOTHER NIGHT-ALARM - SYMPATHY WITH THE EGYPTIANS - FEROCITY OF THE NESTORIANS - APPROACH OF THE STORM.

Is the beginning of April, Dr. Grant, having now traversed the mountains alone for four successire summers, went in again, taking with him his new associate. The pasha had provided a kawass to comteract the effects of his late message to Nirwa; but he refused to accompany us further than the banks of the Tigris, - most probably according to orders, as he had no horse, or anything that looked like preparations for a journey. Dr. Grant thought it a good riddance, and we were soon on board the rude boat that ferrien us orer to Assyria. The side was four feet high, and our mules were half lifted, half forced into the mass of horses, men and clonkeys, that already filled the boat. 'The river, when highest, is sometines here a mile in breadth: but, though so high that the brilge of boats lay useless along the western bank, it w is not now very mide, and we were soon lande 1 in the mud on the opposite shore.

Once fairly beyond the ancient mounds round Khoyunjuk, we proceeded, in a northerly direction, to the right of the Khosar, across the plain of Assyria. Fields of grain waved on 
all sides. Flowers blossomed in the middle of the road, and gazelles bounded lightly away on our approach. These are hunted only when the ground is so wet that their hoofs sink deeper than the feet of the greyhounds that are kept in every village for the purpose. At half-past six P. M. we stopned at Baibûgh, a mud village, withont a tree in sight in any direction. Noisy storks held possession of the roofs; and flocks and herds, just home from the pasture, filled the eourt-yards. Our room was made of mud throughout, with the exception of the beams which supported the earthen roof, and a door that, by way of economizing lumber, was only half as wide above as below. The very candlestick that served dimly to reveal our supper was of the same material.

On our arrival, the villagers had insisted that, though they harl plenty of eggs, yet they had no hens; but, through the perseverance of Dawûd, one made its appearance with the eggs and pilav. The latter was hot, but our host obligingly famned it with his capacious shirt-sleeve, as we sat together round the dish.

Next day, April 5, an hour's ride brought us to Khorsabar, where we spent two pleasant hours in visiting the excavations of M. Botta, now so well known that they need not be described. The mud-houses of the village contrasted uddly with the royal splendor laid open below them; and an Arab churn a goat-skin, half full of milk, kept extended by a stick, and the whole suspended from a pole that leaned against one of the huts - was jerked back and forth by a particularly sunburned dairy-maid, in the very face of heroes and demigods of olden time.

We visited Khorsabad several times afterwards, and $M$. Botta presented an ancient Assyrian seal to one of the missionaries. The device, which is here inserted, represents a priest standing before the sacred tree; the winged symbol of the deity over him, and a dagger behind him. The stone is chalcedony, 
and a hole is drilled through the upper part for the insertion of
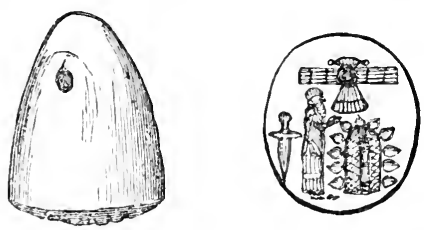
a string, as seen in the side view.

The excavations of M. Botta may be too well known to need deseription; but his amiable character and unaffected kindness towards those of another faith may not be so familiar. That was not unappreciated by those who received a very different treatment from an English missionary, and will never be forgotten while memory lives. The writer eannot forhear transcribing a note that now lies before him, as it shows how a French consul, though a papist, knew how to unite good-will to others with the performance of his own duties. He had lent his large copy of Freytag's Arabic lexicon to one of the missionaries, and this is his reply to a note of thanks when it was returned:

"MY DEAR SIR: I cannot say that I thank you for the return of the lexicon, because I am sorry that you do not want it any more, and $I$ lose an occasion of being useful to you. A for asking me how you can return the favor, permit me to say that such an idea ought never to have oceurred to you. I have been happy in being able to help you, and the pleasure I hat in doing so is more than I want for my remuneration."

How could intercourse with such a man be otherwise than pleasant?

Leaving Khorsabad, we jassed on toward Seidkhan, where a fountain that bubbles up at the foot of a low range of hills turns fiour mills within the space of half a mile. At one time we had no less than twelve ancient mounds in sight at once. These are generally close by a spring or water-course; and where neither exist, those who live near them sometimes ask the passing Frank to point ou the well they believe them to eonceal. 
Crossing the low range that runs north-west from Jebel Maklub, we continued over a high undulating surfice, that commanded a delightful view. On our right rose the summit just mentioned. More to the east, the snowy peaks, above Ravandooz, glittered in the distance. Direetly in front lay the plain of Yezid Khan, with here and there a village nestling at the foot of an ancient mound. On its opposite margin rose the fluted cones of Ain Sifneh, our resting-place for the night. Just heyond, the dark rocky slope of the outer barrier of Kûrdistan swept round from Akra on the east to Elkosh on the west. Here and there the pinnaeles of the Gara peeped over that, telling of more rugged scenes beyond. Descending from this eminence, we erossed the plain in the midst of a thunder-shower, n'ar the water-shed, between the Tigris and the Zab, and were oon safely quartered for the night.

Ain Sifneh (Fountain of the Ship) is so called, they say, because here Noah built his ark. If so, trees must have been more numerous in those days; for now, besides a few fruit-trees in the village, none were to be seen in any direetion. It contains nearly one hundred houses, mostly Yezidees, with a few Kurds, and four or five families of Jews. Some poor people from Jelû had spent the winter here. But everything betokened poverty. The marks of oppression and insecurity were visible on all sides. Yet a kid, sporting amid the witheren grass on one of the roofs, reminded us that while the wicked are like the grass upon the house-top, that withereth afore it groweth up, yet, after they shall have passed away, eometh the kingdom of Christ that shall never end.

Dr. Grant, who was too hoarse at night to speak, found the cutaneous irritation of swarms of noeturnal visitors as effectual as a regular preseription. But his companion, who had been kept awake by them the night before, and fared no better now, did not find the treatment so beneficial.

As we rode off at sunrise, we saw some of the Yezidees kissing 
the walls of one of their temples, as they caught the earliest rays of the sun. We had a fine view of the plain of Navkim, on our right, directly between us and the sun; but soon entered a narrow defile, that shut out all other sights. High in the rocky wall, on our left, was the old cave of a hermit, whence you might trace the stream up and down the ravine, by the oleanders in full hoom upon its banks. The willow, the hawthorn, and other' flowering shrubs, added variety to the view. There, on the west, . is the glen of sheikh Adi, the holy place of the Iezidees. The fluted cones of the temple shoot up among the trees, like the top of a New England spire. The sides of the glen seem to close together above it, dotted with the buildings occupied by that singular people when they come here to their amual feasts. At this place the missionaries spent a week, during the hottest of the summer of 1844 .*

Keeping up the main ravine, we passed over into the valley of the Gomel, and continued up the stream for several miles, west of north. Here we passed field after field, and village after village, totally desolate. The soil was fertile, the climate delightful, but war and oppression had emptied the land of its inhabitants. Then bearing more to the east, we came to Bastawa, the village of the chief of Mezury, equally desolate. His wife was here, with a few attendants, securing their rice. Her appearance at once commanded attention. The tassels of a silk shawl hung gracefully round the lower part of her turban. A green silk jacket, lined with fur, hut now much the worse for wear, covered a dress of coarse blue cotton, suggesting a sad contrast between former wealth and present porerty. $\mathrm{Her}$ features, once beautiful, now revealed a spirit roused, rather than broken, by misfortune. When Dr. Grant asked lodgings

* For a further description of it we must refer the reader to the excellent work of Mr. Layard, vol. I. 225; and his more recent " Babylon and Ninereh," 81-94; Bibliothece Sucra, 1818, p. 148, and Missionary Herald, 18.53, p. 110. 
for the night, she raised her form to its full height, threw back her braided hair, and, pointing to the roofless houses and ruined castle, to her own rags, and those of her attendants, - "See there!" said she. "You have stripped us of all! You bave driven us forth heggars in the land; and now, do you ask for hospitality? We have nothing for you. Go to them with whom you have still left something, and may God be judge between us!" This is but an outline of an impassioned address in her native Kûrdish, imperfectly transkited by our servant. Gesture, position, look and tone, could not have been improved by the schools; and yet there was no extravagance. Her proud spirit scorned to yield to the violence of passion. All was said with a dignity of sorrow that affected us even more than her words; and we were heartily ashamed of our Turkish costume, that had led her to mistake us for her oppressors. When she learned who we were, she at once offered to share with us what she had; but there was nothing for our horses, and we were compelled to go on, two hours further, to the Nestorian village of Bebozy. As we passed along the steep side of the narrow glen, we could speak of nothing but the heroine of Bastawa. When will this energy of character in these mountains be consecrated to Christ, and employed in doing good?

We could not but notice the contrast hetween her and ladies of her rank in Mosul. Some of them oceupied palaces, the marble pavement of whose courts was diversified by parterres of Howers or fragrant orange-trees. In the lofty rooms, the gilded stucco of the roof looked down on Persian carpets, and divans of brilliant-colored satin. Numberless mirrors, plain, or made up of small pieces disposed in a variety of shapes, multiplied many times the exquisite arabesque that covered the walls Large lines of Arabic, with its graceful curves and intricate combinations, painted on the plaster in vivid colors, extended round the apartments. But, when one of the missionaries called, he was always left outside the door till the house was cleared. 
Then, in suci a room, coffee was served in cups with silver holders, and zostly sherbets and perfumes welcomed the visitor. But, with the exception of the host and his attendants, not a foul was to be seen; and it would have been deemed gross impoliteness had the guest made the slightest allusion to the family. Thus secluded in the house, in the street the woman must follow her husband at a respectful distance; and, should a Frank lady publicly take the arm of her husband, she would do it at the peril of being mobbed. On the road the fellah is sure to he riding his donkey, and smoking at his leisure, while his poor wife trudges on foot, if not bending under a burden besides.

Dr. Grant and his associate were one day busily writing for the post, when the wife of a respectable Mohammedan merchant brought in her only child for medicine. They lived close by; and, as she came frequently, she rentured in unattended. Her appearance was unusually prepossessing. She could not have been over thirty years of age, and her little boy was not far from ten. Dr. Grant was so busy he did not, at first, attend to her; and, leading forward the invalid, she began to plead for him with tears, saying, anong other things, "He is all I have in the world." - "What!" said the doctor, "have you forgot your husband?" _ "Husband!" she repeated. "Can a hushand love? He is a stranger to me, and I to him. Ah? the religion of Jesus is hetter thin Islam; it does not tolerate such things as ours." The truth was, he had minried others since her, and she was cast aside; while the attention - let us not call it love - once lavished on her was now transferred to her younger rivals; and these did all they could to embitter an existence already almost insupportable. She was retained only for the sake of her son; and on him now centred all her love. But even he had been trained to despise her; and, all the while she was pleading in his behalf, with a mother's earnestness, he was mocking, insulting, and, with a domineering air, ordering her to be silent. 
After the doctor had attended to him, she began to tell her own ailments; but he could only reply to her account of them, "I have no medicine for a broken heart."

Christian mother! how many such hearts, as tender and sensitive as yours, are breaking! How many doomed to drag out life in misery like this, and then die without a knowledge of the Saviour! How much would you take in exchange for your knowledge of Christ? And what are you doing to make him known to such as these?

Leaving the Kurdish village of Kalanowa in the valley, we climbed on foot to Bebozy, where, for the first time, we saw oals and evergreens on the eminences around. An Armenian friend of Dr. Grant made us his guests; and an excellent supper of bread, olives, honey, dibs (grape molasses), and the flesh of a wild boar, followed by a dessert of pomegranates, was very acceptable. The village abounds in firuit. Grapes, eherries, pears, peaches, plums, figs and almonds, grow here, besides olives and pomegranates. Citrons and limes thrive in some of the warmer valleys. Most of the fruit used in Mosul is carried from these mountains; and the gall-nut of commerce is one of the staple exports of the province. The wild boar is very troublesome, - rooting up the fields and destroying the crops The bear and wolf are less common. An animal like the leopard but smaller, is sometimes found. Foxes are plenty. The martin is more rare; and the otter is caught, occasionally, along the waters of the Zab.

The Nestorians of this and a neighboring village had turned papists within a fortnight of our visit. The Bishop of Elkosh hald told them all the world had turned, and threatened to eurse them if they did not turn too. They had no priest, no teacher; and, said they, "We were sheep withont a shepherd; - what could we do?" On the walls of the church were some paltry prints, of whish they seemed ashamed, but did not dare to take them down. The churg' was well supplied with MSS.; but 
they seemed rather a memento of the former prosperity of the rillage than appropriate to its reduced population of thirty houses.

Next day we passed over the mountains to Hordepni, a small Nestorian village, where is a chamber hollowed out of an isolated rock, called the Tomb of Nooskee; but who he was we could not ascertain. Beyond this our road was the same that Dr. Grant passed over in 1839, into the Sapnah. Tûra Gara, still covered with snow, stretched away on our right, south-east by east, to the Zab. To the west it is more broken, and, under various names, forms the southern boundary of the valley, as Tûra Natineh is the northern.

The valley is about two miles wide at this point, and twice that width at Dawûdia. There is no marked elevation between the streams that run into the Habor and the Zab. They break down abruptly through the coarse sandstone at the very outset, and intersect the whole valley with deep ravines, for the most part impassable.

We spent the night at the Kûrdish village of Baderesky, whose fields, fenced with thorm-bushes, presented a formidable barrier both to man and beast. Contrary to the usual custom, our host was not only very obliging on our arrival, but continued so, even after we had giren him his bachshish in the morning.

A ride of four hours - April 8 - brought us to Amadia, through the ruins of the Turkish cump. The town rose almost directly above our heads. Stopping every few moments to breathe, we had leisure, during the ascent, to note the precipice, from twenty to forty feet high, that crowned the slope. A stair-like road led from the fountain outside the gate to the platform above. Here and there were marks of cannon-balls, and mines exploded by the Turks. The town is so strongly situated by nature, that, during a fire months' siege, some thousands of balls, fired by the besiegers, killed only eleven men; and famine, rather than force, compelled a surrender. They 
tried, but in vain, to poison the wells, eight of which are excavated in the rock, from one hundred to one hundred and fifty feet in depth. The town looked ruined and wretched. Fifteen years ago it numbered two thousand houses; now there are little more than two hundred. First the plague swept away eighteen hundred of the citizens; three years after, the noted Kûr Bey sacked the place; two years later, Reschid Pasha recovered possession, inflicting new injuries. Then Ismael Pasha, four years after, revolted, and was taken prisoner at Akra, in 1839. In $18+2$ he regained possession of the place, to be again driven out by the siege just mentioned. At this time there were about forty houses of Jews, twenty of Christians, and one hundred and sixty of Kunds. Only two Armenian families remained, out of thirty. One of this people, though an employé of the government, showed us the wounds made by the fetters he wore in prison, till three thousand piastres were extorted from him. A boy had lately been compelled to turn Moslem by the daily torture of the lash. Several Nestorians were driven off, in our presence, to work for the soldiers, amid blows and abuse. The priest, and even the women, are, in the same manner, driven to the most menial services, and made to carry wood like beasts of burden. One man applied for medicine for his eye, blinded by a blow from a soldier.

Making our way through a crowd of insolent soldiers, who seemed to long to treat us like the rest, we found the floor of the best room in the castle coated with mud; the divan was old, coarse and ragged, and, with a dozen guns, swords and pistols, composed the only furniture of the apartment. Passing through rumed halls, once adorned with stucco, we found the governor in a rough kiosk, built of boards. But the beautiful view from the window relieved for a moment our sad impressions. The whole valley of the Sapnih lay spread out before us as far as the Zab. Beyond its silver thread, the peaks of Ravandooz towered high, in their robes of glittering white. The gov- 
ernor had profited by the temperance lecture in Akra, in 1839 but has little encouragement to do good, as he is liable to be displaced whenever he fails to extort enough from the ruins to satisfy his superior at Mosul. His seven hundred soldiers force the inhabitants to labor for them for days, without giving even a morsel to support them the while.

We remained here from Saturday till Tuesday, as Monday was so rainy we could not leave. But it did not detain us, in the end; for the rain opened the roads, till now impassable from the snow. On Sabbath one asked how he should know which was right. Here were the Nestorians, the Chaldeans, and the English, all following the same Bible, and all different. Dr. Grant: "We want to teach you to read the Bible, and judge for yourselves." — " But," says he, " the readers disagree, as well as we." Dr. Grant: "However they may differ about some things, others are very plain; as, "Except ye repent, ye shall all likewise perish;' "Without holiness no man shall see the Lord,' and the like." The .man then turned to a Chaldean priest who was present, and demanded why he had never told them this. "Is it so written in the Bible?" - "Yes," was the reply. "Then why do you speak against these men, who do not slander you, and teach us what is in the Bible?" Such topics as confession, and the relative importance of fasting and repentance, were then discussed at length, with much interest. It cheered us to find many scriptural sentiments advanced in a place so dark, and we could not but rejoice in the good fruit that would yet abound here also to the glory of God.

The town has one mosque, -- whose tall minaret is the most beautiful and prominent object in the riew, - an Armenian church, and two synagogues. The Nestorians worship in a room in the house of Kasha Mendo.

On Monday a Rabbi took us to visit the synagogues. In the outer court of one a few flowers occupied the only place reached by the sum. Here we fund some masses of leaves, wet, and 
covered with mould, - we could not call them books. They were volumes of the Talmud, laid out to dry. Inside the synagogue the rough posts that sustained the roof were rotten. The rain dripped freely from above into deep holes worn in the soft clay floor. We could scarce find a place fit to stand on, and the damp, close air was perfectly intolerable. We hardly dared stay long enough to look round; and still here was a place of worship for many of this miserable people! More than forty rolls of most beautiful Hebrew manuseripts were here going to decay; yet money could not induce them to sell one of them. The same description may answer for both synagogues, even to the number of manuscripts sent from the villages around for safe-keeping. When will they cleave as elosely to Christ as to these copies of the Law and the Prophets, that speak concerning him?

Dr. Grant next went to the house of a patient; and, on leaving the ruinous abode, we were surprised to learn it was the house of one of the magnates of the plaee. If the homes of the rich are so comfortless, what, thought we, must be the dwellings of the poor? We were not long in suspense, for we entered some of them. But how can we describe them? Without windows and without doors, - unless a hole in the wall, half choked with rubbish, be called such. From this you descend into the interior, as into a dungeon. In the darkness you can scarce discern their utter emptiness. A cradle and an earthen pot comprised the whole furniture of one; two earthen pots and a pile of rags that of another. The dresses of the inmates hardly served the purposes of common decency; and how they were protected from the cold we could not imagine. In some places night brings relief to the miserable. But in many of these houses there was not a rag to keep them from the damp earth, or cover them from the cold. Who would not deny himself, that such sufierers might know of the grace that is in Jesus Christ? We were not surprised to hear that many had died of hunger, and others - a thing very uneommon in western Asia - had put an end to 
their existence with their own hands. One of the Jews had first killed his wife and then himself, to get rid of the misery he could endure no longer.

The priest's brother, by whom we were entertained, - Kasha Mendo was from home, - was so poor that we had to buy our candles and provisions, such as we could get, in the wretched bazaar.

The tradition that this place was founded by a woman seems to point to Semiramis; and its strong position favors Miajor Rawlinson's idea, that it is the Ecbatana, or treasure city, of the Assyrian kings.

As the road was unsafe, the Mutsellim sent five armed Kurds to escort us through Berwer, and we took three or four Nestorians to carry our loads over the snow. Descending from the eastern gate, we crossed the valley, and entered the pass of Geli Mazûkah. Dr. Grant, in former journeys, had tried another, a little to the east, the bolder of the two, as this was the more beautiful. Ancient terraces, moss-grown and covered with ivy, ran along the rock above us. The torrent leaped from ledge to ledge, in white sheets of foam; now wetting with spray the vines that corered its banks; anon plunging, with hoarse reverberation, into some hidden pool, deep down among the rocks. High over our heads the road crossed the stream by a stone bridge, of one arch; and on a conspicuous point of the opposite cliff the ruins of a mill made the scene yet more picturesque. Above this the glen enlarged into a little terraced interval; then contracted again, so rough and wild we had to unload the mules; and, after crossing and recrossing, scrambling and climbing, we were glad to rest at the top amid the snow. This extended far down the descent before us. The range, this side of Tyary, presented an unbroken surface of white, and the road to Ashitha was not open for some weeks later. In the descent we fared tolerably well, with our broad-soled Turkish boots; but the mules floundered through with difficulty, even 



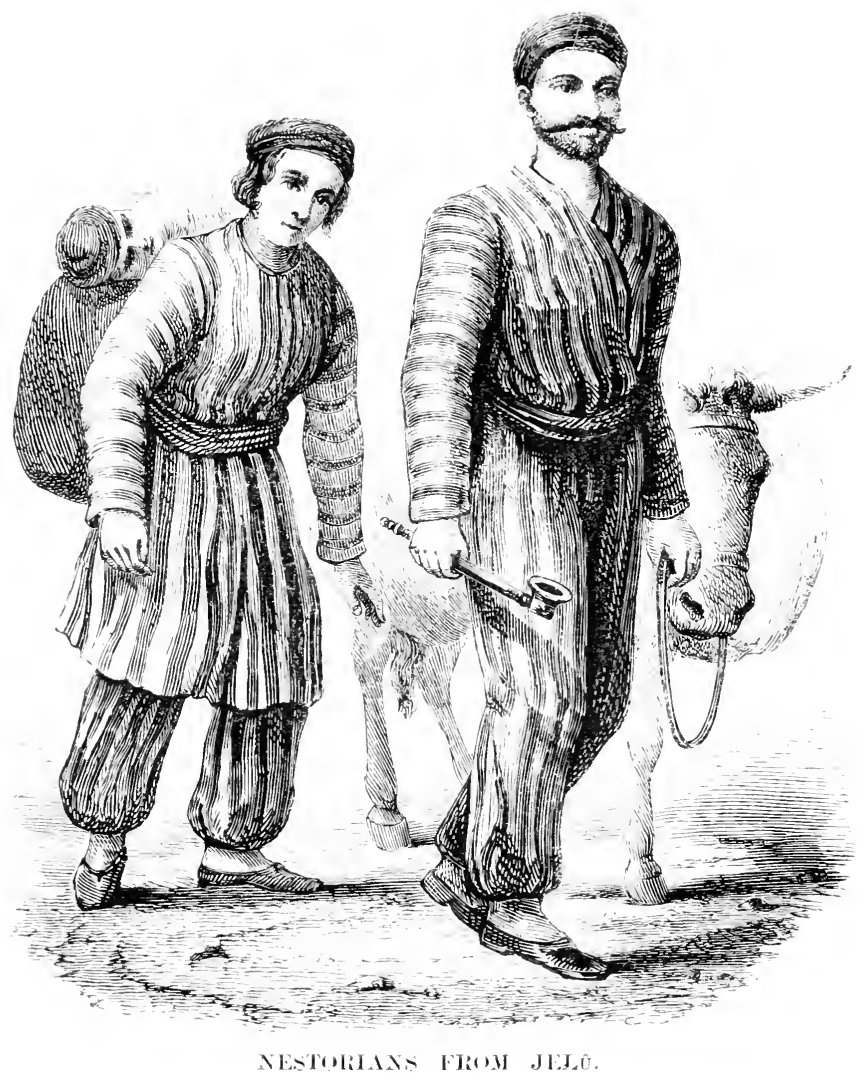


without their loads, to an upland valley, covered with the beautiful croeus, which was the zozan of Amadia.

Below this, we sunk, boots and all, through the soft snow; and the mules had to be helpod by the Nestorians through drifts up to their saddles. But these troubles were soon forgotten, in a lovely vale, about a mile in diameter, with a river murmuring pleasantly through fields of grain, and tall poplar-trees standing like guardians around the whole.

The village of Terwanish, six hours from Amadia, - perhaps the place Dr. Grant had to pass so silently at midnight, the year before, - occupied the summit of an eminence beyond, and presented a solid stone wall on the only side that was accessible. As we approached we could see men on the roofs scrutinizing our little company, and prepared to welcome or repel us, as circumstances might require. Here we procured some refreshment, which we ate in the road, as they would not trust us inside the village barricade; and, sending back our Nestorians, commenced the ascent of the mountain before us. Two hours brought us to Deshtany, a wretched village of half-naked and half-famished women and children, where no one would take us in. But their filth and vermin reconeiled us to our fate; and we gladly followed some Nestorians to Zarne, where we spent the night. On the mountain we met many of the Nestorians going to pasture their flocks on its southern slopes. The women carried their full share of baggage strapped to their backs (see plate). The men were well armed, and kept a sharp look-out for enenies. Zarne lay out of our way, but we were well paid for our vivit. The people listened eagerly to religious instruetion, and were diligent in improving this second visit of a physician to their secluded home. The castles of this border-village are strongly built of stone and lime. They are full of loop-holes, instead of windows; and the door, high up in the wall, is reached by a ladder, that is drawn up after the villagers are safe within. Altogether, they looked so threatening that, in 
case of a shirmish, we would much prefer to be inside, rather than among the assailants.

The aged priest of the village, with his silvery beard, though quite vain of his learning, seemed bent on increasing his stock of information, with Yankee pertinacity.

Next day, we passed over the extremity of the range, by a road so rocky and steep that it would have been as impossible for us to stay on our mules as for them to carry us. Dr. Grant, as usual, was worn out with the walk; and was glad to remount some miles below Lezan, where the river squeezes through between mountains that barely open wide enough to admit its passage. Where not too steep for any regetation, they are covered with forests of the Quercus Valonia, that produces the gallnut of commerce. Impressions of fern were frequent and varied on the schistose rocks; and the black-walnut tree, whose fruit is valued both for food and for the oil they press from it, was quite common near the river. The oil is burned chiefly in the churches, where animal fat is not allowed. As we drew near Lezan, beautiful green terraces were snugly fitted into the bottoms of the ravines, and houses surrounded by poplar and peartrees dotted both banks of the river. Every available nook and corner was eultivated, and presented a striking contrast to the desolation above. It was Industry sitting amid trophies already won, and meditating new triumphs. Soon Lezan appeared, in an uneven valley on the left, about half a mile in width, and extending back a much greater distance. Terrace rose above terrace from the water's edge, as long as water could be brought to them, by any means, from the mountains above. The village contains probably about two hundred houses. We were kindly received by Kasha Kena, whose hearty welcome made us quickly feel at home. Man of the villagers flocked to meet us, and we were soor quietly setcied in Dr. Grant's winter quarters. An American stove and a mattress stuffed with wool were lux- 
uries espeeially grateful. Indeed, everything presented a pleasant contrast to the sad reeollections of Amadia and Deshtany.

As Mar Shimon was anxious to see us soon, we went next morning to Ashitha. The torrent was too deep to ford; and, even had we erossed it, the usual road was impassable from the snow. We were therefore obliged to elimb the steep face of the mountains by a by-path, pronounced impractieable for mules, though Dr. Grant, who was too weak to walk, retained his from neeessity. His companion would trust his neck to no feet but his own. So, with shalwar tied up about his knees, and hair sandals on his feet, he trudged on one weary mile after another, to the end. Sometimes, as he sat down to rest, he was reconciled to fatigue, when, looking back, he saw the hind feet of the doctor's mule sprawling below the path, and kicking the loose stones down into the valley; one Nestorian holding on by the bridle, and another aiding the rider to dismount, till all fuirly in the path again, the doctor remounted till the same process had to be repeated. This was bad, but a week's illness with the ague, which paid the pedestrian for his over-exertion, was certainly no better.

The first house we entered was the Kalleita, near the church, which Dr. Grant had formerly made his home. Te stopped outside till we were annomed, and were much at a loss to know what to make of a stack of straw just inside the door. As it did not hinder the free entrance and exit of others, we ventured in also, in our turn, and found a small passage by one side of it into the apartment. It had been erected to break the force of the wintry winds, and, when wam weather returned, was taken away. This passed, as near as we could discern, through the smoke, a row of men, seated on the earthen floor, extended more thin half routd the room. Mar Shimon occupied a silk eushion in one corner, with his bed and sundry articles piled up behind him. We approached and saluted him, and were soon seated on a felt by his side, where we could sur- 
vey the assembly, as our eyes became accustomed to the smoke and darkness. Each one had his pipe, and secmed quite at home, - going out, coming in, and chatting as familiarly as he chose. Mar Shimon welcomed Dr. Grant as usual, and his companion had no occasion to complain of any want of attention. Still, it was evident that the Patriarch was quite willing to reap what advantage he could from two rival missions. The reports of the doctor's castle-building had given place to others yet nore extravagant. Before our arrival, it was currently reported that the Pasha of Mosul had imprisoned him and cut off his hands; and, again, that the same pasha had employed him to do all he had done in Tyary. This last led a Kûrdish chief to make the neighborly request that the Nestorians should kill him as soon as he arrived. It was on account.of such reports that the Patriarch had ordered a large company of Nestorians to meet us beyond their frontiers; but our unexpected arrival prevented the intended kindness.

But, to return to the Patriarch's apartment. A confused pile of wood, kettles and earthen pots, dimly appeared behind the stack of straw at the door. A fire burned in the middle of the floor, and the smoke, instead of going out of doors, was busy adding to the polish of the roof, that already shone like jet from the smoke of years.

If our own quarters, to which we removed in a day or two, were inferior, it should be borne in mind we did not aspire to patriarchal splendor; and, for the edification of the curious, we will here describe them. We occupied one room in common, whose walls were built of stone, lairl up in mud. This last was left squeezing out between them, like plaster on the inside of laths. The earthen floor was almost as smooth as a muddy road after a hard frost. In the middle of this was a heap of earth, shaped like a tray, where we built our fire. Here ali the cooking was done, within some five feet of our beds. These, which served also for seats by day, consisted, first, of a layer of millet- 
straw, to mitigate the roughness of the floor, extending a little beyond our mattresses, so as to keep us out of the dirt. Thesc last were home-made, and stuffed with mountain wool. A quilt apiece and our Turkish cloaks made all cosey at night, and our saddle-bags answered very well for pillows. We wrote with our portfolios on our knees, our ink-bottles in our hands, and various little articles deposited, for want of shelves, on the projecting stones of the wall behind us. Our wood was piled up in one corner, where it was thrown down by the men who brought it nearly a day's journey on their backs. Our bags of meal, earthen pots, and a goat-skin of honey the doctor had laid in for the winter, oceupied another. Though there was no chimney, we found no inconvenience from the smoke; for, let the wind blow from what quarter it would, there was a place for the one to enter, and a second for the other to go out. When it blew from the door, just opposite our beds, bundles of straw were inserted both above and below it, to serve the same purpose as the stack at the Patriarch's. On the same side was our window, also stuffed full of straw, which a visitor begged for his cow one day, alleging that it was a sin to waste good provender for such a purpose. The north-west side was intended to be entirely open in summer; but, as the snow round the house was ther in places, two feet deep, it was filled with a partition of wieker work, that excluded neither cold nor snow. As this was the cold quarter, and storms.were not infrequent, we leaned some loose boards against it, as an alditional defence; but these were often blown down, and made sad havoe among our earthen pots, though we did not feel so keenly their loss in this way as when they fathlessly emptied our diuner in the fire. This was a poor place for an ague-fit, but it was the best we had; and the record of the weather reads: "A $A_{1}$ ril 27 , rain and hail, nearly all day, covering ererything with ice. 28 , rain, turning to snow. May 1st, rain and hail; $2 \mathrm{l}$, rain and very cold wind; $3 d$ and 4th, rain, hail and snow, each day." Though this, we were 
asured, was musually mild for the season, as the feast of Mar Gyuergis (St. Genrge), that occurs alhout the 1st of May, is generally celebrated on the surface of the unmelted snow.

This was the only room then finished, though the plan embraced a building for the residence of three mission families. sixty feet square, besides a chapel, school-room, stables, $\mathbb{E}$. As our mode of building would not warrant the erection of a second story, it necessarily occupied a large surface; but, with a roof within the reach of every boy, and windows almost level with the ground ontside, it was hardly a castle in any sense of the term. Yet Dr. Grant has been charged with building on an isolated hill, commanding the whole valley; and surprise has been expressed that one so well acquainted with the character of the people should have heen so indiscreet in the choice of the location, and the size of the edifice. As to the last, perhaps no more need be said. Considering the number of families to be accommodated, one can scarcely tell what was to be spared; and no one acquainted with the character of the mountaineers would recommend mission families to be far from one another, in case of the absence of any of the missionaries. As to the location, though I am sorry to differ from the distinguished traveller who refers to it, yet justice to the memory of a departed friend requires me to say, what he himself will remember, on reflection, that the hill is not isolated, as, writing perhaps from memory, he has inadvertently called it; though it may appear so to one approaching it from below, where the higher part of the same ridge is concealed from view. He will recollect, also, that the valley is so irregular, and the village so scattered among smaller valleys, running in various directions, that it is absolutely impossible one position should command the whole. The different and widely-separated hamlets that compose tine village can be seen at one view only fiom the mountains which enclose the valley. As to a lower position, the fevers prevalent in the narrow valleys, to say nothing of other annoyances, led Dr. Grant wisely to avoid 



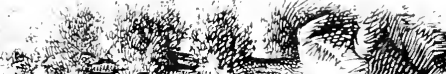

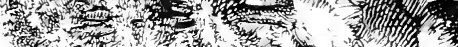
(1) ty
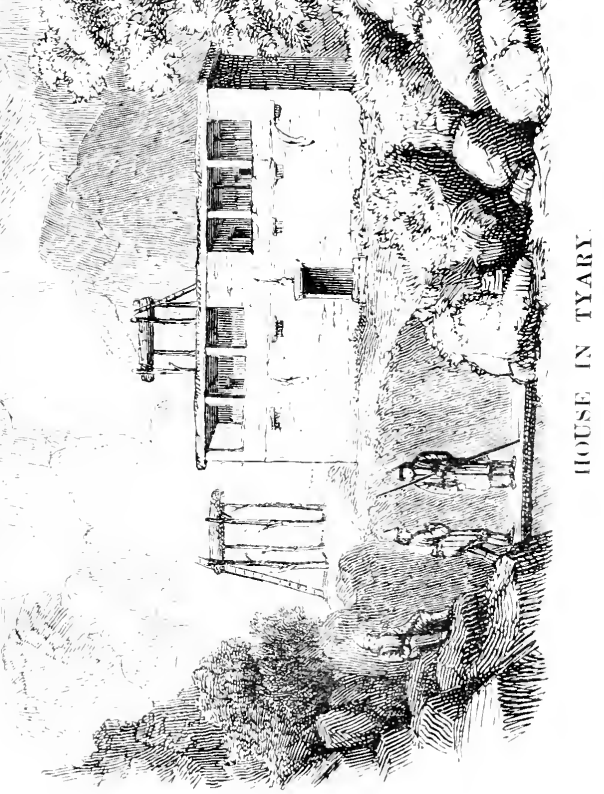
the

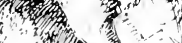


them. We shall soon see the alterations that had to be made in the unpretending mission-house, in order to transfer it into a castle.

The accompanying plate gives a very good idea of the generality of native houses in the mountains. For a further description of the house, see p. 133, and the Arzaleh, p. 185.

The feast of Easter (according to the Nestorians) occurred on the $23 \mathrm{~d}$ of April, and for fifty days previons they had been keeping their great annual fast. During this, both old and young rigidly abstained from food till after evening prayers. Even decrepit old women might be seen, seated on the grave-stones, before the chirch, groaning from sheer exhaustion, as the day advanced. It was touching to see them conscientiously abstain from the seanty morsel at their side, because, as they thought, God had forbidden it. No Christian could have seen such selfdenial and not been ashamed to excuse himself from any service required by his Redeemer.

On Saturday evening (the $22 \mathrm{~d}$ ), all was active preparation for the morrow. Clothes were washed ; the best garments were got ready; barbers were busy shaving the head, - a custom as strange to us as our shaving of the chin would appear to them, - and busy housewives were ransacking their stores for the substantial materials of the feast. They formerly offered sacrifices on such occasions, and still do in some villages; but the custom was lately discontinued here, because, as they said, Jesus Christ was offered once for all, and "our guilty souls require no sacrifice beside." A pleasing proof that their minds, though dark, are not altogether dormant.

The people began to assemble in the church as early as eight P. 3., for the services commence at midnight, and are not finished till late in the morning. They are thus lengthy, because every one in the village must now partake of the sacrament. The very children do so as soon as they can go alone, baptism being regarded as a sufficient preparation. Confirmation, apar's from baptism, is unknown among them. 
In the morning the sun shone brightly. The very day seemed to sympathize with the general joy. The snow had melted unusually early, and almost the whole of the lower part of the valley was bare. At an early hour the narrow paths were thronged. These are narrow indeed, - every inch of arable land is so preciou:, - and barely allow a man to pass between terraces abore and below. Indeed, some parts of the village are utterly inatcessible on horseback. As the day advanced, the scene became more animated. From all directions they converged towards the church; most carrying some contribution to the common stock. Oecasionally huge wooden bowls of millet boiled in buttermilk - the great staple of the feast - were borne on poles, by two stout men, after the mamer of the grapes of Eschol. The conical felt hats of the men, - some black, some white, the new dresses of the women, and the gaudy handlerchies that formed their head-dress, presented a pleasing contrast to the tattered garments of the poor. Some of these had been patched so often it was hard to tell the color or texture of the original material, or by what attraction the apparently loose fragments were held together.

At noon we left our quiet reading, and joined the crowds pressing towards the church. The poplar-trees were just budding, green grass was pursuing the retreating snow, and riolets peeped out here and there from among the stones. The steep sides of the surrounding mountains seemed to hedge in our thoughts from wandering over the earth, and direct them upwards to heaven and to God. But our attention was soon engrossed by the multitude before us. It seemed scarcely possible that the village had contained so many. The little field in front of the church was full. The flat roof of the kalleita was covered; each stone in the grave-yard was crowded; and many sat on the damp earth, as on an accustomed seat. The sound of their voices rose literally above the noise of many waters. Each voice had been trained to be heard from hill to hill, above the roaring torrent, 
and no gentle influence had taught it to modulate its tones. The very multitude, too, roused those accustomed to the solitudes of the mountains, and the prospect of war was not fitted to allay excitement. Yet all was harmony. Old men, whose white beards rested on their staves, looked with pensive kindness on the little children, - perhaps thinking of their own childhood. perhaps of the dark future, near, but unoticed in their thoughtless glee. The young men were full of the threatening prospect, and vainly sought, in the opinions of each other, a relief from their own forebodings, though some seemed to have no thought beyond the hilarity of the moment.

A merry group of girls, under a wahut-tree at some distance, were all absorbed in the dince. They were not orer twelve years of age. There was no finery in their dress, and as little of art in their morements; but the regular stamp of their feet on the green turf, their gleeful voices and happy looks, recalled the dances of the daughters of Shiloh, in other flays. They joined hands in a circle; then each hand moved simultaneously, and every foot was lifted and set down as by one impulse. This was repeated thrice, and then the whole circle flew round three steps. Again they beat time to their own wild music, and then arlvanced as before. Joy supplied the place of art, and left no regret for the substitution. But now the feast was ready, and the multitude were seated in rows on the ground, - reminding us of the fifties on the grass on another occasion, - and at regular intervals the huge bowls of millet were set between them. These were three feet in diameter; and in the centre of each a small bowl of melted butter was imbedded in the mass. Each attacked the segment nearest him, and dipped his spoonful in the smaller bowl. There was no second course; and we did our utmost to enjoy the first, though, probably, with less success than those "who dipped with us in the dish."

When the men were satisfied, the women and children - who till now had busily replenished the butter-bowls - sat down in 
their turn, and, after them, the poor ate what they could, and then earried home the remainder.

We were glad to return to our quiet quarters, and spend the rest of the day more in accordance with our views of Sabbath enjoyment.

The feast was continued at their houses for two days more, and, soon after, was followed by the feast of Mar Gyuergis, the patron saint of the village church. The people regard these fusts and feasts as commandments of the gospel, and essential to salvation; hence a burden of ceremonies is substituted for the moral law, and a righteoumess of their own for the grace that is in Christ; - the very errors from which the apostles labored to defend some of the early churches.

Dr. Grant had an interview with Mar Shimon before he went to meet the emir at Chumba. The Patriarch renewed his assuranees of unabated eonfidence, and his determination to coöperate with him for the improvement of his people. He spoke of the self-denial of Dr. Grant, in leaving the comforts of home to labor, amid much privation, for their good; and did not conceal his apprehension of danger, as well as privation; - hinting that, even among his own people, there might be those who, for money, would do the bidding of the Kûrds. When he asked what course he himself should pursue with the emir, the doctor told him to "Follow peace with all men;" and, when afterwards sent for to Chumba, refused to go, on the ground that he wanted him only for political husiness. The emir had written a very cordial reply to a letter we sent him soon after our arrival.

Early one Sabbath morning we opened our eyes on the startling sight of five armed Kûrds seated in firont of our beds. They bronght a letter from Badir Khan Bey, desiring a professional visit from the doctor. Though well aware of his bigoted hatred of Christianity, he deemed it prudent to try to win his confidence; and, as his complaint wonld admit of delay, he promised to risit him in the course of a month, when he shonld 
be more at liberty. With this reply we dismissed them, not altogether satisfied about the real object of their errand. Ifardly had they gone when Kasha Auraham came in, with many anxious inquiries about them. The chief men of the village soon followed; and, after a spirited discussion, pronounced them spies. Some wished to pursue and kill them; but then they were our guests, and that would not do. Some said one thing, and some another, till Dr. Grant put the gospels into the hands of Kasha Auraham, to translate several chapters, making practical comments as he proceeded. The translations male at Oroomiah were understood but imperfectly here, though they afforded nuch aid in communicating truth; and a little alteration -- perhaps variations of dialect, noted in the margin - Dr. Grant thought might adapt one translation of the Bible to all parts of the country. We sent many copies of the Scriptures, in ancient Syriac, to the more remote districts, generally at the request of the priests, who were able to read them.

The people could not resume the building of the mission-house till after Easter, and then they demanded higher wages, assembling, to the number of fifty or more, and making rather tumultuous demonstrations. Dr. Grant sat quietly in the house, regardless alike of the threats outside and the advice of some professed friends within, who urged him to pacify them by acceding to the demand. But he simply wrote down the names of the leaders of the nob; and it was wonderful to see the effect on those fierce mountaineers. They soon became quite manageable; and, instead of demanling higher wages, they quarrelled with each other for employment at the former rates. The only trouble now was the old one of limiting the number of workmen. Those who did work wrought with a will. Some carried large stones on their backs; others brought water, in goat-skins, from the stream close by, and poured it on the loose earth, which their bare-legged companions, with pick and spade, were working into mortar. The masons, with their rude hammers, reared 
the rough walls as men used to do before plummets were invented. Eight men on a side seized the cross-bars, to which a poplar beam was lashed, sometimes twenty-five fect long, and nearly a foot in dianeter, and moved off with the burden on their shoulders, - up hill and down, across terraces and over walls, relieved at intervals by another set of bearers, till they deposited it safely in its place. Split sticks and branches were laid across these; next stones and bushes; and, above all, a layer of wet earth, duly stamped and rolled, completed the roof. The frequent storms hindered the work out of doors, and made us none too comfortabie within. New earthen roofs are not always storm-proof, as we found out when the muddy water filtered through, one rainy night, upon our beds. The stone roller is the remedy in such cases; and Dawûd was soon at work repairing damages. All at once his thunder ceased. What was the matter? We waited, and waited: it was not resumed Perhaps he had fillen from the roof in the dark. Torch in hand, the doctor sallied out, but nothing was to be found; - till, after' long suspense, the servant returned, bringing the Nestorian who had taken the care of the roof by the job. The leak was soon stopped, and all asleep again. But the scene of that stormy night still remains in the picture memory paints of our mountainhome, menorable as the only instance in which the writer knew Dr. Grant to manifest anything like fear; - an illustration of the strange inconsistency of ou nature, that makes a bold man timid when there is least orcasion for timidity.

Each succeeding day bronght with it the same rude outline of rough walls and earthen floor, smoky fire and crowded room; for, after Mar Shimon left, it was the common lounging-place of the village. Our school was in another room, under the care of Priest Ezeieh, who led his forty pupils out on the house-top whenever they could enjoy the warmth of the sun. In our room the sick, the lame and the blind, eongregated, with their tattered garments and tales of distress. Some came for books, and 
some for bargains; and those who had no otier object came to gossip. One old priest was paid for five trees, and then insisted they were but four. At another time he sold a dozen wooden spoons, and then carried off money, spoons and all. An old man, with a beard that would have been white had it not been embrowned with smoke, used to seat himself by the fire, day after day, with his pipe resting on the ground between his knees, and retail the village chronicle of seventy years. There was $n 0$ being alone, even in our own house. Sometimes a visitor would take his siesta quite at his ease; and not unfiequently they performed a work of self-examination, -- confined, however, to the outer man, - which, though it relieved them, was quite too near our beds to be either agreeable or safe. We learned, by sad experience, to sympathize with the Gyptians in their third plague, if nothing more; for, however laboriously we rid our clothes of our tormentors at night, fresh recruits were always ready for the vacant places. And yet it would not do to enforce sanitary rules; and it was poor consolation to know that the attempt to keep even one corner of home sacred from such intrusion would secure its demolition, as the depository of a treasure we were trying to conceal.

Fatal assaults on each other, also, are by no means rare. One man had killed his cousin in a quarrel, in 1842, and compromised the matter by agreeing to pay the usual price of blood, fiom twenty-five to fifty dollars. Twenty dollars still remained unpaid; but, though his life was in jeopardy, he would not sell itn article below its full value to secure his safety. Another was brought to Dr. Grant, at this time, horribly mangled. Single-handed he had attacked a whole Kûrdish village, to revenge some trespass on his pasture-grounds; and, after wounding several, - one of them mortally, - he was overpowered, and, as they thought, despatched with their daggers. His friends found him, however, still conscious, and carried him a day's journey orer the mountain. Under Dr. Grant's skilful 
treatment, he recovered, much to their surprise. The men of Ashitha had a reputation for robbery that made them the terror of surrounding districts. This ungorerned temper, and the passion for plunder, led to the drawing of daggers, in plain sight from our door, over so trifling a matter as a few stalks of fennel, and only the interference of Dr. Grant prevented actual bloodshed; for, unlike the Arabs, they seldom carry on a war of words alone.

These traits of the Nestorians themselves; the known hatred If the Kurds against Franks, especially when seeking to elevate the Nestorians, their hereditary foes; the suspicion with which the Turks regarded ow morements in what they called a rebellious part of the empire; and the almost audible approach of war, - filled us with lark apprehensions for the futme.

About this time. Dr. Grant wrote to Mrs. Jones, at Oroomiah, as follows:

" Would that I could hear of the influences of the Holy Spirit among you, or witness them in this more difficult and trying field! Shall I say I have some sad hours, in riew of the want of this blessing? Nothing else can either prepare our way, or give success. In relation to this branch of the mission I hardly know what to say. Clouls and darkness are round about, and we can see light only by looking up. Perhaps my ill health adds gloominess to the riew. But I am not disheartened. Gorl will over-rule all the wrath of his enemies, for the good of his own glorious cance. I rejoice that Mr. L. is at length in the mountains. Mr. and Mrs. Bliss, and Dr. Smith, are expected in June. I am anxions to see the mission fairly established before they lose any assistance that I can render. But all our respects are uncertuin. Our short-sighted plans may soon be matle to give way to purposes infinitely wise.

"I fear lest the ill health of my brother Ira, and the pressing wants 0 ? my children, should call me to America; but, so long as 1 am ible to labor here, I have no wish to return, strong a. 
are the ties that bind me to those dear to my heart. I regret, therefore, to add that my health has not been so good, of late. The tax upon my strength, in these difficult mountains, is more than my system can bear, to saly nothing of the responsibility and care that burden me. Wrery day brings some new anxiety, and all is increased, rather than relieved, by the prospect of others sharing these trials and privations."

On the 11th of May, Mr. L. returned to Mosul to bring in the mission families, and the question of what was expedient in the matter occasioned us no little anxiety. On the one hand, were these grounds for apprehension. On the other, to vacillate now was to forfeit all the confidence won with such hazard and difficulty by $\mathrm{Dr}_{\mathrm{r}}$. Grunt. The sight of our families in the mountains, while it assured the Nestorians of our friendship, might also disarm the suspicion of the Kinds. The confidence thus placed in them might satisfy even their jealous hearts of the innocence of our intentions. But we were not long in suspense. The clouds gathered new blackness; not only breaking up our labors, but even threatening to exterminate the people whom we sought to benefit.

When Mr. L. reached Mosul, he found the Porte had refused firmans to Dr. Smith and Mr. Bliss, on the ground that it could not at present tolerate Franks in the mountains. Determined to subjugate Kûrdistan, it wished to do so without the embarrassment occasioned by their presence.

In the mountains, Mar Shimon, failing to make peace with the emir, summoned his warriors to the field. But they refused to obey the call. Even the much-dreaded anathema, prononncer against each hoise which dil not fumish one man, fell unheedod because it fell on nearly all alike. The Patriarch, with the fe who rallied to his standard, could only irritate the Kûrds, with out inflicting material injury. The burning of the bridge at $\mathrm{Ju}$ lamerk, and a foray, headed by his brothers, from Diss, especially provoked their rengeance. 
The promised aid of Barlir Khan Bey was not wanting. A thousand of his soldiers were already on their march. They were first heard of on the Habor, opposite Ashitha, and all that rillage was in instant commotion. About forty were at work on the house when the news arrived; and Dr. Grant, who observed the workings of their minds, says that, though evidently afraid for their flocks, they were nothing daunted for themselves. Labor was at once suspended. Each ran for his gun ; eighty of the more active started off to reconnoitre. Others hastened to bring in the more distant flocks. All were ready to meet the foe; but the scouts returned without having been able to find them. The next night alarm-guns were a gain fired by the shepherds on the mountains, and answered instantly from all parts of the village. The night was dark, and the sudden flash of the guns, followed long after by the report, was a stirring sight. None knew how great or how near was the danger; but each at onee prepared for the worst. Some hid their more raluable effects in a secret cave. Others buried them in pits nearer home. As Dr. Grant knew that none but a large army could penetrate into the valley, however smaller parties might rob the pasturegrounds, he determined to remain to the last, ready to go at a moment's notice. Before midnight, the welcome signal proclaimed "All 's mell!" and next d:y all were quietly at work as before, though angry with their neighbors of Halmon and Jeramin for what they deemed a false alarm. These villages, unprotected themselves, are the sentincls of Tyary to the west, and had already suffered nuch from both Kûrds and Turks. That very spring, a detachment of lawless mercenaries had fallen on Halmori, and killed twelve men and seren women, before the villagers cound either Hee or submit. The lat of their flocks were carried off ; and, as nothing remained to plunder, the pasha sold the villages back again to the Patriareh.

The injustice of blaming these villages was athowledged at once, when they found that the force had actually passed, but, 
instead of attacking the zozan of Ashithat, where they feared too warm a reception, had gone against that of the Malek, near Malota, where Dr. Grant had left all so haply, less than a year before. It was a real Kûrdish chappow. Sereral men, women and children, were slain, and four or five thousand sheep driven away, before a foree could be gathered to the rescue. The loss fell chiefly on the Malek, doubtless in revenge for his constant support of Mar Shimon against the emir. Redress was out of the question, for who could punish the Bey of Bulitan? The Malek could only deplore his loss, and anticipate yet greater evils. But, though all expected these, through a strange want of mion, no measures were taken to arert them. Mar Shimon dismissed his few remaining followers, and returned nearly alone to Ashitha, full of wrath against the enir, as the true cause of the disaster. He was also provoked with his own people, for their refusal to assist him. He now turned to the Turks, and applied to the Pasha of Mosul for the aid he had been led to expect. But such conditions of submission were insisted on as led to the reply, "We are not foxes, that we should fear, but lions, and can fight!" This was not what was wanted, and the pasha referred the Patriarch to the Mutsellim of Dawudia, as their medium of communication. The answers of the latter, however, were forwarded in Syriac from Mosul, and, without being able to rearl them, he affixed his seal, and forwarded them to the Patriarch as his own. Vague hopes were held out, and submission was still insisted on. At one time the Patriarch was told that Badir Khan Bey would not be allowel to go against him; and again he wrote, "If he sends an army on that side, I will senil another on this;" an enigmatical sentence, doubtless intended to be understood very differently from the way in which it was afterwards fulfilled.

The detention of Messrs. Smith and Bliss, though at first very trying to us, proved, in the end, a nerciful providence, as it 
Was now evident that those in Mosul should not enter the moun. fains, though Dr. Grant did not, as yet, see it duty to retire.

The time had now arrived for his promised visit to Badir Khan Bey; and, hoping to receive new light on the course to be pursued in the present crisis, he determined to go. Har Shimon objected, lest it should look like suing for peace; and Dr. Grant confessed, "In my secret heart I often wished the promise had not been made; but made it had been, and good might grow out of it. At least, I should prove we were men of truth, and, if suspicions existed, they night be removed. At any rate, I felt that I must go;" and the Patriarch, finding him resolved, at length approved of the measure.

Dr. Grant thus writes to Mr. Stocking, June 4th: "As to our situation now, our reinforeement is detained. Mr. L. urges me to join him in Mosul, and not stay here, where the present attitude of the Porte will embolden both the pasha and the Kûrds to seek my life. God only knows what may grow out of all this, or what may be my future course. Hitherto my Turkish protection has been a great check upon men of blood. May the Lord guide me in the right way, and may His great name be glorified!" 


\title{
CH A P TER X VI.
}

\begin{abstract}
VISIT TO BADIR KHAI BEY, - FIERCENESS OF MOUNTAINEERS - KESTA ANTIQUTTES - KALA KUMRI - THE HABOR - A KLRDISH "CUISINE", - DR. GRANT'S COMMISSARIAT - A SABRATH IN ZACHO - RULE OF BADIR KHAN BEY - JEZIRA - FORTS IN MOUNTAIN PASS - DERGULEH THE ASSEMBLED CHIEFS - ORIGIN OF THE WAR - BADIR KHAN BEY'S PRONISE TO DR. GRANT - IIS CHARACTER - SUMMER QUARTERS - A GEORGIAN - HOW A KURUISI CHIEF SPENDS TIE DAY - TRADITION OP THE ARK - SHAKII - RETERN TO ASHITHA.
\end{abstract}

Ox Thursday, June 6th, he left Ashitha, at six 1. w. Many had collected to express their kind wishes for his safety, and all seemed to hope that good would result from his visit; for, though he had repeatedly told them he could not interfere with politics, yet they knew his labors could prosper only in a time of peace. Even the shepherds, as he passed along, left their flocks to invoke blessings on his journey, and bespeak his mediation.

He could not but pity these last, - poorly sheltered from the storm, with barely enough to sustain life, and in constant alarm lest they should either be slain or robbed of their flocks, which were their sole dependence. Only a few of then had fallen as yet; but they had an undefined dread of heavier ealamities to come. For, while the Patriarch and a few of his friends looked to the Turks for help, others trusted in the promises of the Kûrds, and most, without any eommon plan of action, sat still, in trembling apprehension. It was their harvest season, - if the cutting of a crop of mountain fennel ean be called such. This is often a time of fierce contention, involving, occasionally, whole villages in war for the quantity is small, at the best; 
the limits of both clans and individuals are indistinetly marked; and the dagger is ever in the girdle, ready to do the bidding of the excited temper. But now each toiled within his own limits in peace, or aided his neighbor to collect the grass, fennel and thistles, into little stacks among the stones. Two hours down the valley, in the district of Berwer, he passed a grove of poplars, the usual mark of a village; but he found only houses burned and plundered by the very people who now trembled lest the same fate should befall their own. Two years before, they had burned several villages, in this district, both Kûrdish and Nestorian, excusing the plunder of their brethren by the plea, that, if they had spared them, the Kûrds would have counted it a religious war, and not only destroyed these villages, but inflicted a ten-fold revenge. Hitherto he had followed the road by which Mr. L. returned to Mosul. Now he turned up the valley to the right, and crossed the mountain by a gentle ascent. The foundations of an old castle, built of immense blocks of stone, show that the pass was once deemed worthy of defence. It is called the pass of Kesta, and is the most practicable road from Zacho to the highlands of Assyria, and thence to Media Atropatene. The scenery here was delightful. Flowering plants lined the path, and birds carolled sweetly under the shade of ancient oaks, on whose branches grew the mistletoe. The sight was refreshing, and reminded the weary pilgrim of a distant home. On the western face of the mountain he passed a Kûrdish hamlet, watered by a stream that flowed into the Habor. Further on was the large village of Aden (Eden), and well worthy of the name, amid its groves and gardens. The stream here dashed through a narrow gorge. On the left, the ruins of an aqueduct, cut partly in the face of the cliff, and partly built up, with great labor, from below, probably dated from the same period as the ruins in the pass above.

After crossing and recrossing the stream, now on break-neck hritges, and now dashing through the water, he emerged into a 
more open country, studded with villages, each ovorlooked by the castle of its chief. 'These last are relatives of the chief of Berwer, who belongs to an ancient family, called by the Nestorians the family of Melka Aziz (the beloved king).

Dr. Grant soon came in sight of his castle (Kala Kumri), perched on an isolated peak, to the right, much higher and smaller than that of Amadia.

The Habor breaks through the rugged chain on the north, and flows almost directly under the castle. Its course is here south-west, till it passes the end of the Matineh range, whence it flows nearly west to the Tigris, forty miles below. Across the river, and some distance above, is another castle of the Hertush Kûrds, then occupied by the noted robber Zeiner Bey. To avoid him, Dr. Grant left the direct road, which here crosses the river near a large Jewish village, and, bearing more to the south, crossed an intervening valley. At five P. M., he stood on the summit of the Matineh range, Ashitha bearing north, fifty degrees east, and the snowy peak of Avrora north, thirty degrees east. At a quarter before seven he found a cordial welcome at the small Nestorian village of Dey. All night long, however, he was kept awake by the howling of the dogs. Villages not far off had recently been robbed; and no one, when he lay down, knew whether he would rise again, or rise a beggar; and it seemed as if even the $\operatorname{dog} s$ shared in the general apprehension.

Next morning he left at five o'clock; course west and westby-north, three hours, to the Habor; then, keeping along the south side of the river, till half-past one P. r., he stopped at an encampment of Kûrds, who had left their village, if not their vermin, to breathe the pure air by the river's bank. Booths of reeds and bushes, from six to twelve feet square, sheltered each one its family; and the shade of a large walnut-tree was the place of assembly. Dr. Grant spread his rug on a coarse mat of reeds, and tried to make up for the losses of the night before. 
But, ere he was fairly asleep, he was summoned to partake of some half-baked barley-bread and sour milk, ponred into a dirty wooden bowl, from a goat-skin that certainly was no cleaner. This was followed by another dish of the same, which had long ago passed into the acetous fermentation. It was by no means a feast to be desired; but it was all the place afforded. He was anxious to go on; and the people told him there was plenty of villages on the road, all better than their own. Happily, a young man from Zacho told him, in Turkish, that there was not a human dwelling in the whole six hours' ride. So he iurited himself to stay, as much against his own will as theirs; and, finding him determined, they left him in quiet possession of all outdoors. In the evening the chief of the village returned from Zacho, and all hastened to hear the news. Such and such villages have been robbed by Zeiner Bey. Badir Khan Bey is raising a large army against Tyary, and says he will break these infidels, or they him. The pasha is collecting an army at Dawûdia, and has ordered the neighboring Kûrds to be ready to march at a moment's notice. Such was some of the news eagerly devoured by all the village, and by none more eagerly than by their stranger guests. As it grew lite, the crowd dispersed, and Dr. Grant, having carefully secured his muie close by his side, soon sunk to rest.

Next morning, he rose with the dawn, bound on his girdle, and, without more ado, was ready for his journey. The sore eyes of the villagers kept him busy, while some bread was half smoked, half baked, for his attendants. Cold water was his chief prescription, - an important prophylactic to the half-naked urchins that gambolled around, and not at all injurious to their sunburnt mammas. The road from hence to Zacho was a mere foot-path, winding through deep ravines and over sandstone hills, clad in dwarf oaks and shrubs. Several villages nestled at the foot of the mountain on the left, and the Habor flowed on the right, swollen by the melting snows of mountains, whose shining 
summits peeped from behind the darker surface of an intervening range to the north-east.

After five hour's' ride, he stopped at a spring, near a hamlet, visited by the villagers in the day-time, to secure their crops, but forsaken at night, for the greater security of the villages at the foot of the mountain. A band of nomad Kûrds passed while he was there; but, as their fanilies were with them, he apprehended no danger. It was not, however, a place to linger, and, moistening some gingerbread and crackers, given him by the good ladies of Oroomiah more than a year before, he hurried on. A mile or two above Zacho, the river runs close to the southern range of mountains, while an extended plain, of great fertility, stretches away, on the north, nearly to Jezira, separated only by the Tigris from the great plain of Mesopotamia. The Habor here flows in a deep narrow channel, through a bed of conglomerate, and is spanned by a substantial stone bridge, very high in the middle, and supported by five arches of unequal size. Another bridge connects the island of Zacho to the southern shore. Crossing this, Dr. Grant entered the place at one P. M., through a gate guarded by soldiers, after a ride of seven hours, exclusive of delay. He repaired immediately to the castle, whose garrison was utterly unable to protect the villages of the district from Kûrdish depredation. Two of them had been robbed the night before; but the robbers escaped with their prey before the deed was known, and what could be done? As long as Ismacl Pasha hired Zeiner Bey to annoy the Pasha of Mosul, and Badir Khan Bey connived at it, no one was safe. Snall parties of soldiers were sent out, but accomplished nothing; and the Mutsellim, like a good Moslem, sent word to his superior, and then sat down to smoke and await the result.

Hearing the doctor was from Tyary, the Mutsellim inquired whether he was a servant of the Balyos (consul) in Ashitha, and would hardly believe that the humble individual before him was 
that distinguished personage himself. Ile told him that Batdir Khan Bey had threatened to drive him from the mountains, and had actually sent spies to see what he was about in Ashitha; but that he need fear nothing in his visit.

As no quiet could be had in the castle on the Sabbath, the doctor was billeted on the head man of the Jews. This was sad news to his Nestorians, as they esteened the food of a Jew unclean. It was Saturday, troo, and nothing could be cocked till after sunset; but the Jews offered arrack, of which, as usual, they had partaken rather freely themselves. They number about one thousand souls, but were formerly much more numerous. As usual, Dr. Grant was at no loss in conversing with them. They showed him their synagogue, the largest building in the place, except the castle. But, though so friendly, they were very bigoted. The doctor never had a Hebrew New Testament returned to him before; and some young men who desired copies were dissuaded from receiving them. Dr. Grant observed here, for the first time, what he afterwards learnt was common, that the Kûrds employ Jews to circumcise their children in the Hebrew mode, rather than perform it themselves at a later period, like the rest of the Moslems. He had more patients than he could attend to, and did not form a farorable opinion of the climate. The heat was very oppressive to one fresh from the cool air of the mountains.

Monday morning he had to ford the northern branch of the river, - a hundred yards in width, and the water reaching nearly to the backs of the mules. His baggage was carried over on men's heads; and a very tall horse, sent by the Mutsellim, landed him safe and dry on the shore. Starting at seven o'clock, he followed down the river, and at half-past eight forded the Hazil, near their junction. The course of the latter stream, from the pass where it breaks through the rocky chain of Mount Jûdi, is due south-west. It is about one-half as large as th : 
Habor, and rises near Shakh, a village two and a half days from Van.

The doctor was now in the territory of Badir Khan Bey; and, after stopping an hour and a half at one Syrian village, to prescribe for the sick, at the urgent request of the priest he spent the night at another, called Dakea. Just before this he passed a village of Nestorians and Jews. The former are few in number on the plain, but more numerous in the neighboring mountains, and are much oppressed by both Turks and Kûrds. Dr. Grant had seen in Ashitha a priest from Chellek, - a village of sixty houses, north-west of the Habor, - who fled from an oppression he could no longer endure; - not, however, till his own brother had been tortured to death, in the effort to exact more money than he was able to pay. The mules of his host in Dakea had been fancied by Badir Khan Bey; and, as no one dares to withhold anything so honored, they had disappeared. The bey had a special fancy for all the good animals of " unbelievers." Of late, too, he had left no alternative to the Yezidees but the Koran or the sword, - alleging that tribute was only the privilege of those who received the law or the gospel, and they had neither. Happily, nrany had warning of what was before them, and fled; but many more were left to turn Moslems, or die martyrs for Satan.

It was not till the year before that the bey got entire possession of this plain. A large village on the road was pointed out as the scene of the last battle. It was one of the night-attacks for which the Bûhtan Kûrds are so famous. The onset was fierce. The defence, by the famous Seiad Bey, was no less determined, till his fall decided the contest. Some of the assailants afterwards described the scene to Dr. Grant, and boasted of their deeds of blood.

The threatened invasion of Tyary was the next topic; and so fully did it seem to be settled, the doctor almost repented of his journey. He was quite interested in the family of his host. 
His wife was the step-mother of children nearly as old as herself; but all seemed fond of her. And yet she did not know their language; and, while their guest conversed with them in Syriac, her husband now and then translated for her into Kûrdish. The doctor was pleased with these and other tokens of mutual attachment, and makes special mention of the refinement of a dormitory separated by a curtain from the rest of the family, - a thing so very uncommon in the region, it could not well pass unobserved.

Next morning, June 13, he left at half-past two $A$. x., to avoid the extreme heat, and reached Jezira in five and a half hours. This, as is denoted by its name, is an island, in the Tigris. It is the Bezabde of Syriac writers, called also Kardû, Bakerdeh, Zozarta, Zabelita, and, by the Chaldeans, Xurta. It is probably the Tigre of Ptolemy, and was an important fortress in the Roman district of Zabdicene, which was subdued under Dioclesian and Galerian. Sapor retook it, A. D. 360, restored its fortifications, and garrisoned it with a colony of veterans. At that time it was a bishopric of the Eastern church; for Ammianus Mareellinus tells us that "the Christian Bishop of Bezabde went to Sapor to entreat him to check the waste of human blood." Heliodorus, its bishop, two priests, and two hundred and fifty others, are said to have suffered martyrdom under Sapor. The place formerly contained five convents. The Nestorian Patriarchate was here for a time, and it was the seat of one of their metropolitans in 1616. The Jacobite Bishop of Azûk - six hours above and two and a half from the Tigris - still retains the title of Bishop of Bezabde; and a Nestorian bishop - Mar Yohannah - resides still nearer in the mountains north-east of the town.

A Saracenic palace, now in ruins, faces the Tigris, and its alternate rows o: black and white stone present an imposing appearance from the opposite shore. They are ascribed to an 
early period of the Hejira, but may have risen on the foundations of a more ancient structure.

It had long been the eapital of the ehiefs of Búhtan, who, at this time, resided in mountain fastnesses, more secure from the Turks. Macdonald Kinneir was imprisoned here, and eompelled to pay a large ransom; and a papal missionary was killed, because the patients he had prescribed for did not recover. A Moslem of the place told Dr. Grant that one of their nobility, returning from an unsuccessful hunt, met with two Christians, and deliberately shot one of them down, saying, as he fell, "That is my game!" - "What could induce him to do so?" asked the doctor. "Nothing," replicd the other, "only, you know, we regard it a great sowab (merit) to kill a Christian." Such has been the character of the place, and such are still the sentiments of its imhabitants. Judgments have overtaken them. Their independence is gone; but their hatred of Christians is still the same. In $1836 \mathrm{Col}$. Sheil found the town almost in ruins, and only, after long seareh, eould obtain a wretehed hovel to spend the day in. No inhabitants were to be seen : it absolutely contained none but a few hundred sickly, miserable soldiers. Plague, cholera and war, had ruined the place. Neither barley nor straw, not even grass, eould be got for his horses. No bread, no firewood; nothing whatever, either from the governor or the bazaar. About that time a nominal Turkish authority was established by Reschid Pasha, and the town was partially re-peopled.

Dr. Grant crossed the river on a raft, as the water was too high to use the bridge of boats. A good stone bridge was built here by Nûrreddin, but has long since gone to ruin, leaving scarce a wreck behind. The Mutsellim quartered his visitor on his treasurer, an old aequaintance, to whom, as physieian, he was no unweloome guest. The best of everything was set before him; and even his worn-out boots were replaced by new ones, for which his host would receive nothing in return. After a late 
breakfast, the doctor wished to set out for Dergûleh, the castle of the Bey; but no guide could be found, till a Fellah, who had come in to buy a sickle, was seized, and ordered to escort him. He begged so hard, however, that, much to Dr. Grant's relief, as well as his own, he was released. Happily a Kûrd was found at the river going in the same direction, and to his care he was at once consigned.

The road led up a narrow glen, in which a stream flowed south-west to the Tigris. From the entrance of the defile, the range - it was the famous Mount Jûdi - stretched away eastsouth-east to the north of Zacho, where it is broken through by the Hazil and Habor. On the left it shut down so abruptly on the Tigris as apparently to bar all progress in that direction, though that pass is practicable in the summer. Xenophon had good reason to remember it, for it must have been here that he resolved to march over the mountains that jutted out into the river, when his prisoners told him he could thus either eross the head of the Tigris, in Armenia, or go round it. The road to Dergûleh is the regular road to Sert and the upper Tigris. The appearance of the place was like that lescribed by Xenophon, where the Carduchi disputed every step, and rolled down great stones on the advaneing Greeks. The pass is now defended by strong forts, two on the right declivity, and three, one above another, on the left. Some of these had been built, and others repaired, that same year, - if not to maintain greater independence of the Porte, for what other reason, and against what foe?

Nestorian masons were allured from Bass, by liberal offers, to labor on them. But the Rayahs of Bûhtan were forced to toil without reward; and, when they complained, were tantalizingly told to become Moslems, and they would be re'eased. Still there were not enough of laborers, and the Mohammedan peasantry were called on to help. This did not suit the Moollahs, and a dangerous fissure in one of the walls was pointed out, as

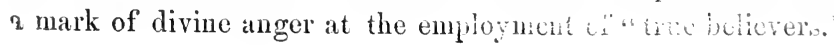


After the forts were finished, the poor Christians were further compelled to build a stone bridge across the stream. Not far below this monument of Kûrdish intolerance a tunnel* had been cut through the rock in early times. It was broken in several places, and seemed just large enough for a man to crawl through.

At the summit of the pass an uneven upland lay before the traveller, and scon two castles and the village of Dergûleh appeared, crowning a high bluff, whose base is washed by the torrent. This was the stronghold of Badir Khan Bey, eighteen miles from Jezira. The castles were square, turreted buildings, whose clean white walls contrasted pleasantly with the rough crags arround. On the north needle-shaped rocks shot up above the rest, and on one of the least accessible stood the treasure-house of the Bey.

In a grassy dell, on the banks of a limpid stream, near the foot of the castle-hill, stood the green tents of Ismael Pasha and the Emir. The latter met his physician at the castle-gate with an incuiring air, and expressed surprise at his presence there. When he was told that it was merely a professional call, he bade him weleone, but added, with significant emphasis, "Do not interfere with our plans." He seemed to fear the doctor had come to make terms for the Nestorians, and so prevent the utter overthrow he so much desired.

Satisfied on this point, he went to announce him to the Bey, and soon returned, and introdnced him as his old friend and physician.

The master of ceremonies required that, on approaching the Bey, he should kiss his hand, according to custom; but the doctor replied, promptly, that he should do no such thing. So he

* Is not this the tumnel where Mr. Layard found the bas-reliefs described on p. 55 of his "Babylon and Ninereh"? His description of the march of Xenc phon, at p. 62 of the same volume, is probably more correct than that f Dr. Grint, as le went orer so much nore of the roufe of the Ten Thousind. 
was left to pursue his own course, and had no cause to complain of his reception then, or treatment afterwards. The Bey offered him a room in the castle, adding that the Emir also wished him to oceupy one of his tents, and he might take his choice. The doctor compromised the matter, by making the castle his home, and spent a part of each day with the Emir, occasionally sharing his repasts, as in former days. Ismael Pasha was here, and had ju-t obtained the release of his wives, who had been detained sixteen months as hostages in Mosul, by engaging to stop the robberies of Zeiner Bey. The conduct of Badir Khan Bey, in harboring this rebel against the government under which he held his own office, and his building forts with one hand while he paid tribute with the other, may serve to indicate the character and position of the man. The truth was, his professed allegiance gave him great influence throughout northern Kûrdistan; hence he was willing to pay for it. It was an object, too, to be at peace with a neighbor against whom he could not contend. When summoned before the Pasha of Mosul, his special military appointment was his excuse for remaining with his army; and as long as he paid the customary tribute, and sent other presents to the capital, the Porte did not care about waging an expensive and perhaps protracted war. He stood ready, moreover, to fight the battles of the Sultan; and now his powerful arm was needed in a long-desired but difficult enterprise.

The existence of an independent Christian people in the very centre of Islam was a reproach no longer to be endured. But neither the regular Nizam, the caralry of the Janizaries, nor the heavy artillery, could cope with them in their mountain strongholds. Men of similar habits, accustomed to their mode of warfare, must do the work. For this the conquests of Reschid Pasha had prepared the way; and, though the Kûrds were not loyal to the Porte, they were zealous for their faith, and eager tc wipe off many a long score of blood. 
If the Turkish government was at all desirous of the conquest of the Nestorians, we need not wonder, after what we have seen of the existing relations between them and the Hakkary tribes, to find these last most zealous in effecting it. Indeed, the Emir was the prime mover in the whole affair. As to the connection of the Turks with the invasion, Dr. Grant was told that the Pasha of Erzrûm, to whom the Nestorian country nominally belonged, was in correspondence with the assembled chiefs, and that the war had received his sunction. He ventured, one day, to suggest to the Bey that he had heard the Pasha of Mosul would aid the Nestorians. With a smile of derision, the Kûrd gave a most decided negative, as one who knew perfectly well whereof he affirmed. The refusal of firmans to Messrs. Smith and Bliss was now explained. Khan Mahmûd, a Kûrdish chief, subject to Van, was also at Dergûleh, at the request, as was said, of Badir Khan Bey.

The complete subjugation of the Nestorians was the all-absorbing topic, and the chiefs spoke about it before Dr. Grant without the least reserve. Both the Bey and Emir assured him of their protection, if he remained in Ashitha; and engaged that not only his property and person should be unharmed, but, also, all who might take refuge in his house. They promised, moreover, that the whole valley of Ashitha, as far as Lezan, shoul? be spared for his sake, if the inhabitants would only submit and paly tribute. He thanker them for their kindness, and told them he would depend on their redeeming their pledge about the mission-house, whether he remained or not. As for the people, he promised to tell them of the offer, but eould neither adrise them to accapt or reject it. They thought this over-scrupulons. "But," said the doctor, "suppose eril should grow out of it, would they not say I occasicncd it?" "What!" replied the Bey, "do you doubt our pledge?" and he repeated it again. Dr. Grant, in return, explained at length our settled policy of nonintervention ir political inatters, further than related to our own 
protection. He then showed him his firmans, \&c.; but the Bey neither rose, as is usual, nor heard them read. He merely handed them over to a Moollah, saying, "They are not needed here; you are our guest, and it is all one whether you have firmans or no. Our word is security enough in Bíhtan."

The Emir's hatred of IIar Shimon could not be concealed, in some of these interviews. If was evidently impatient of every day's delay, and was much annoyed to hear that Heiyo had been restored to fuvor. Though, in the matter of the invasion, he was the learling sirit, his position among the chicfs was quite inferior to that of the Bey. Both he and Ismael Pasha might have elaimed precedence, as descendants of the Abbaside Caliphs. But the personal influence of Badir Khan Bey raised him far above them, though he could claim only a respectable Arabian ancestry. In devotion to Islam he was hardly second to the Dervishes and Moollahs, with whom he was proud to be classed. They were his privy counsellors, and much of the severity of the war must be laid to their charge. They inveighed with great vehemence against the Nestorians. It was such a work of " charity" to destroy those "infidels" as would meet with rich reward in Paradise. "Kill all the men," they cried, "who will not receive the Koran. Take their women and children. Raise up a race of believers from the former, and train up the others in the faith of the Prophet, on whom be blessing and peace!" To increase hatred against them, they were called Franks, and even said to wear hats. The conical felt hat, worn in Tyary from time immemorial, was said to have been introduced by Dr. Grant, and was quoted, even at the capital, in extenuation of the war!

The health of the Bey seemed almost forgotten, in these more stirring topies. It had improved already, under the exciting hope of a conquest, reserved for him, according to his flatterers, as "the favored of Allah." Still the Hekim must feel his pulse, and give the name and nature of his disease. Aware of his 
voluptuous habits, he was able, after gravely counting his pulse, to tell him his feelings, with such precision and minuteness as induced a very high opinion of his skill. Satisfied, too, that the coarse fare of the Zozan and its bracing air, away from his wellfilled harem, - it contained more than thirty, - would do nore good than any prescription, he confined his alvice to such general directions as, if followed, would have been very beneficial. But a score of the inmates of the castle must be attended to, and the Bey must see all that was lone. A farorite servant was bled, and no water was at hand to wash the arm. Knowing he could not engage in their prayers unless it were washed, the doctor asked whether he would have it bound up as it was, and the Bey at once replied, "We keep nobody here who does not pray." The answer was characteristic of the man.

Dr. Grant was seized, on the 14th, with such violent and peculiar pain in his bowels, he could hardly resist the impression that he was poisoned. He spent most of the day lying in the tent of the Emir, thinking of the attentions of the kind friends that make sickness almost a luxury at home. His poor Nestorians, too, so far from their native valleys, and hearing so much of war and slaughter, could hardly eat or sleep. They also were ill, and longed to leave, if, better than their fears, they might escape with life.

The doctor asked leave to return, but the Bey would not hear of his going. His principal officer was sick at a Zozan, higher up the mountain, and nothing would do but the doctor must go and see him also. There was no refusing; so he assented, with the best grace he could. The Bey was to leave next morning for his own Zozan, and it was arranged that Dr. Grant should start at the same time for the other, and return to him in two or three days.

That evening, the horses and mules of Badir Khan Bey were shut up in the castle-court, to the number of two hundred. Tents, provisions, carpetis and the like, were all got ready; and, 
at dawn, were on the more, with his harem and a score or two of attendants. 'Two small camnons were also hrought out, but finally left, as too heavy for transportation over the mountains.

The Bey and his personal attendants remained behind a few hours, that all might he marle ready for his arrival at the camp. Dr. Grant took his leare in a grove of fruit-trees, between the castles, where the chief held his levees. He noticed, in passing through the town, that, though it contained six hundred houses, - as many as Jezira, - yet they were neither old nor rumous, as there. The whole had grown $u_{p}$ under the administration of the Bey. The morning was delightful, and a gradual ascent of four hours bionght him to his patient. In his guide he recognized a young Armenian who had entered Mardin with him four years before. He was now a Moslem, and, though ignorant, was full of the bigotry so characteristic of those who leave a purer for a more corrupt religion.

His new patient was a Georgian, baptized in the name of Christ, but sold in childhood to a Turk, who gave him his freedom on his becoming a Mussuman. His fine form and features bore witness to his lineage, and his education befitted a better lot. Though not yet forty years of age, he had served no less than eighteen Pashas, and now he lay among Kûrds, in a little hut of oak-bushes; all, he said, because it was written in his forehead, - aud who can alter the decree of Allah? Poor man! The doctor pitied him, and did what he could for his relief. But his disease was deep-seated, and he was too much the slare of appetite and prejudice to improve the little chance that was left him.

On the 18th, Dr. Grant returned to the camp of the Bey, distant three hours north-by-west. At the top of the first range a beautiful prospect of mountain and valley opened before him. The Dergîleh creek came down from the north-east, in a valley partly wooded and partly under cultivation, and then dashed through a rocky gaip in the mountain to the left. The opposite 
side of the valley seemed the highest, but both retained nore or less of snow. In front of a cliff, on the left declivity, was a green lawn, dotted with the black tents of the Bey. His own was noways distinguished from the rest, except in size, being about thirty yards by ten.

If there was a change in his dwelling, there was no less in his personal appearance. The robe of Damascus silk had given place to the goat's-hair coat and striped shalwar of the Kûrds. His richly-embroidered turban was exchanged for another of a dark cotton fabric, spotted with red. But the ivory handle of the same heavy dagger protruded from his girdle, and the same line of kohl still stained his eyelids. At early dawn he sallied forth, with one set of attendants to drive together the game, and another to supply him with loaded guns, while for an hour or more he thinned the rauks of the mountain pheasants. Coffee was served on his return; then came company. Breakfast followed, and business filled up the forenoon, till he retired to his harem at noon. Another levee in the afternoon, and dinner closed the regular routine of the day. This was but little interrupted by the occasional removal of the camp higher up the mountain, for better pasture and cooler air. It need not be added that the hours of prayer were serupulously observed by all his people, as soon as the sonorous voice of the Moollah repeated the adan (call to prayer). A class of twelve brightlooking boys also took regular lessons in reading from one of their religious teachers.

But the preparations for invasion were becoming daily more mature. An army was soon to march against Diss, and Dr. Grant was anxious to get away, especially as he could do so little where he was of direet missionary work. The Bey recommended him to return by a nearer road, whi.h he pointed out. As it would have enabled him to explore the country, he felt inclined to take it; but, as it lay through the country of the Hertûsh Kûrds, his Nestorians remonstrated against passing near that dreaded 
tribe; and, as it might be easy to murder him in that distant district, and then charge the crime to its irresponsible inhabitants, he concluded to return by the way he came.

He accordingly retraced his steps to the abode of his Georgian patient, whence he had a view over half the horizon, such as few positions can command. The plain of Mesopotamia extended as fitr as the eye could reach, without a tree to break the uniformity. Just before him, south five degrees east, was the bare summit of Mount Jûdi, the reputed resting-place of the Ark. Arabs, Turks, Kûrds, Christians, and even Jews, agree with Josephus and other ancient writers in making this the place. The Peshito, instead of "Ararat," reads, "the mountains of Cordu." So also do the targums of Onkelos and Jonathan. Assemani says that a convent here bore the name of " the Ark," as early as the third century, but it is now supplanted by a Ziyaret of the Moslems. The Ararat of Armenia rests chiefly on Armenian tradition ; and Consul Brant, of Erzrûm, thinks its inaccessible character is against its claims. Besides, the region is too cold for the olive; and Mohammedan writers state Jûdi to be the true location. The prospect also took in one of the rivers of Eden; thus, if the preceding view be correct, bringing the two cradles of the race into close proximity. 'Two or three days' journey beyond the Timris the mountains of Sinjar are seen rising out of the plain. They bear south from twenty degrees to forty degrees west; and directly in a line with its eastern extremity, on the same range with Hount Jûdi, stood a castle, guarding the pass by which he was about to return. Just below him was another Kûrdish Zozan, where, in the evening, they assembled in a circle, and repeated simultaneously, "La Illaha il Ullah" (there is no God but God) ; at first slowly, but gradually increasing in force and rapidity, till they were in a perfect frenzy by the hour together.

On Friday, the 23d, he set out on his return. A gui le was sent by the Bey and a purse of gold; the first he accepted, the 
last he declined, giving his reasons in a subsequent note of thanks for his attentions, and expressing reliance on his promise of future good-will.

In the uneven valley at the foot of the mountain he passed a mound with a black mineral protruding from its sides, and scattered in fragments in the path. His guide said it would burn, but an unpleasant odor prerented its use. Some specimens of this, with many others, both geological and botanical, were lost in the subserfuent invasion. Leaving Dergûleh an hour on the right, he struck directly for the pass and castle mentioned above. A road, winding among deep ravines and over partially-wooded hills, led to the summit, where he made a meal of the last of two or three sea-biscuit, bronght by Mr. Homes to Mardin, four years before. The castle stood on a rock, two hundred feet or more above the pass, and, like the rest, had recently been repaired. It would contain many more soldiers than were needed to guard the zigzag path to the plain below. This was so steep that he was obliged to walk till he could hardly stand. But, once at the bottom, his way led through a lovely valley, watered by a stream flowing between trees that overhung its waters.

In this valley the village of Shakh lay environed by gardens and vineyards, and a ruined castle gave a yet more peaceful air to the scene. It was a refreshing contrast to the warlike camps he had just left; though even here were servants of the Bey sent, as usual, to secure his half of the harvest the villagers were now threshing in the fields. The sun had just set as he arrived, and a white-turbaned Moollah, in the absence of a minaret, was repeating the call to prayer from one of the house-tops (Luke 12 : 3). But all else was soon forgotten in a circle of Nestorians, who welcomed him to their quarter, and gathered around him on the roof, where he spent the night. He was a day too late to see their bishop, Mar Yoosuf, who had gone that morning to visit ten of his villages to the eastward. They are so few 
and so scattered among lawless Kirrds, that, though greatly in need of the gospel, they are rather an unpromising field of labor. Dr. Grant left an assortment of our Syriac publications for the bishop, and spent a good part of the night in exhorting those around him to search the Scriptures and stand fast in the truth.

Next morning, starting at four o'elock, he rode for an hour and a half by the side of the dashing torrent (the Hazil), before he reached the plain. At eleven o'clock he stopped at a Chaldean village, where they furnished him a breakfast of rice and milk, fiesh from the buffaloes just driven in from pasture. The priest arcepted the last copy of the Epistles he had with him, and a Jew took the first copy of the Hebrew New Testament he had ever seen. Large fields of cotton showed that the soil was fertile, though most of it lay waste, - the winter pasture of nomad Kûrds. Three hours further brought him to Zacho, where he spent the Sabbath among the papal Syrians. Their spacious church is nearly empty. The town has shrunk far within the ruined rampart of former days. Even the island is but half covered with houses; so it was ruin, ruin, ererywhere. From this place the pass of Shakh bore due north-west.

Monday morning he started at four o'clock, and, pursuing a more sout'nern route than before, passed through Baderusky, nine hours and three-quarters from Zacho. He had intended to return by Dawûlia; but a blook-feud between his attendants and a village on that route compelled him to alter his course for Dey. That lay two hours and a half to the north-east, and there was just time to reach it; but an accident detained him, and so, picking his way in the dark, over the pathless crags, at the imminent hazard of his neck, he arrived once more among kind friends, late and weary.

Another ride of twelve hours brought him to Ashitha, Tune 27 th, where he was welcomed more cordially than ever; first by scores of the shepherds, who came to meet him, and then by the 
Patriarch himself, who had been waiting for his return. To the repeated inquiry whether there was danger, his two attendants uniformly replied, "Even unto death." And their own fear, justly excited by what they had witnessed, soon communicated itself to all around them.

28* 


\section{II A P T E R X V II.}

COMMENCEMENT OF THE STORM - VISIT TO MALEK BERKHO - SLALGHTER IN DISS - RETURN OF DR. GRANT TO MOSUL - MASSACRE AT CHUMBA, AT MAR SAWA AND SERSPIDHO - DESTITUTION AFTER THE SLACGHTER - MAR SHIMON FLEES TO MOSUL - MISERY OF THE CAPTIVES - SUFFERINGS OF TIE REMNANT - INSCRRECTION IN ASIITHA ERINGS DHSTRLCTION ON THE WHOLE VALLEY - BCTCHERY AT LEZAN - LAYARD'S ACCOUNT - ATROCITIES OF ZEINER BET - FALL OF TEHOMA - STATISTICS.

Up to this moment the Nestorians had done nothing to prepare for the impending crisis. Accustomed to regard their rugged mountains as a sure defence, many still indulged rain dreams of safety. There were heart-burnings, too, ill befitting their situation. The emir had offered peace to the Nestorians on condition that Mar Shimon should lay aside all civil authority, and settle down at Kochannes as head of the church, leaving politics to the Maleks and himself. This many of the Nestorians desired should be done, and accused Mar Shimon of being the cause of all the calamities impending orer them, becanse he would not make peace on this condition. They were angry, too, because he widened the breach by corresponding with the Pasha of Mosul. The Patriarch, in turn, upbraided them, because they had not aided him to compel the emir to terms. This, and the unconciliatory course he pursued towards his own people, particularly in Tyary, so far alienated them that his authority was, in a great measure, lost. They had already defied his anathema, pronounced against every family that did not send a man against the emir in the spring; and now, such was the state of feeling that any general plan of defence was 
utterly impossible. Each village looked after its own interests, and left the others to their fate.

Moreover, reports were so various and contradictory, no one knew when or where to expect an attack. Even the reports about Dr. Grant did not agree. One made him a prisoner of Badir Khan Bey; another said he was making terms for them; and a third, that, failing in that, he had gone to Mosul to complain to the pasha. Hence their eager interest to hear from him what and how great the danger was. That it was imminent was now evident to all. From the open manner in which the chiefs had talked with him, Dr. Grant felt at liberty to tell the Nestorians what they had said, and make the overtures already mentioned. His duty to them would not allow him to do less; and, as a missionary, he could do no more. He urged them to union in council and concert in action; but did not advise what that council or action should be. That he left entirely to themselves.

The question was not left long in suspense. The Kûrdish army was already on its way to Diss. The Patriarch tried to warn his family of their danger. He also sought to raise troops to go to their relief; but in vain. As none knew where the blow would fall, each refused to leave his own village exposed, in order to help a distant tribe.

At this juncture Suleiman Bey summoned the Nestorians to surrender, threatening invasion if they refused. But little confidence was put in the offers of any of the chiefs. Even the Patriarch did not believe Badir Khan Bey would spare the valley of Ashitha, as he had promised. He regarded the offer rather as a plan to divide them. The whole country seemed given up to destruction, and waited in dread suspense for the fatal blow. At length, after long diseussion, it was agreed to meet in council at Mar Sawa, and decide there what course to pursue.

Dr. Graut now felt strongly inclined to retire to Nosul till the storm had passed; but the poor people were so disheartened 
by the proposal, he resolved to remain as long as his presence could he of any service. Hitherto, he had based his resslution to remain chiefly on the ground that, if the course pursued by the Turkish government was sufficient to drive him out of t'ie mountains, it was sufficient to keep him out, and, consequently, the mission was at an end; for, if he could not go on quietly with his work, there was little lope that, after leaving, he ronld be allowed to resume it. He wrote to $\mathrm{Mr}$. L., July $3 \mathrm{~d}$ :

"Your favor, received this morning, makes me half inclined to go to Mosul. Tell Mrs. L. that sometimes I should ike some of her good nursing. I am often reminded of it when I feel ill, and realize that $I \mathrm{am}$ alone. But $I$ have a sort of premonition that $I$ shall be an invalid as soon as I leave this exciting seene of toil ; if, indeer, I am not before." He then expresses an unwillingness to leave a field where, even in weakness and danger, he might do some missionary work, for Mosul, where t'ıe Board had forbidden us to labor; but adds, "I shall retire as soon as I think Christian prudence requires, and not expose myself to danger uncalled." In a letter to Dr. Anderson, he say; :

"There is no calculating what a day may bring forth. I fear that these unhappy lands are doomed to yet greater miseries. War and commotion is the order of the day; but God reigns! A glorious day is at hand. The deepest darkness precedes the dawn. Our faith may be sorely tried; but we will not despair. Even in these trying events God has purposes of mer sy. We may not know them now, but the veil will be removel. But, should our work be arrested, 'what,' it will be asked, 'avails the toil and suffering, the precious lives that have bcen sacrificed ?' I answer: Let them but awaken the prayers of God's children for this dear people, and they are not lost. Nor would the price be too great for the persevering and agonizing prayers of the church, should other lives be laid on the same altar. Christians have yet to feel that it is not by might or by power, but $b$ the spirit of God, that the world is to be conver ied; and 
of missionaries, even by their death, only awaken more prayer for the Holy Spirit, they will not have toiled in vain." Do not these rords, in view of events shortly to be related, seem like the utterances of an ancient prophet?

Just at this time, Malek Berkho, of Salaberka, was taken sick, and sent for him. He was friendly to the emir, and hostile to the Patriarch. Mar Shimon strongly dissuaded him from going, urging the motive the Malek would have to purchase his own safety by putting hin to death.

Though Dr. Grant had a very low opinion of Berkho, yet, as he hoped to be able to reconcile him to the Patriarch, he concluded to go. He had trusted himself in the hands of the emir, Heiyo, and Badir Khan Bey; and now, small as the prospect was of doing good, he did not shrink from a similar danger.

On Friday, July 7, just ten days after his return to Ashitha, he left it for the last time. He never again saw the home where he had hoped to live and die, and make his grave among the Nestorians. At Lezan, two additional messengers from the Malek hastened his journey, and some leading men in that village, who hoped he would induce Berkho to attend the council, also urged him to proceed. One of them - Shemasha Yonan - accompanied him to the bridge, helped to drive the mules into the water, and, when all were safe over, parted from him to meet no more; for, on Dr. Grant's return, he had gonc to the council, where few ever assembled, and in the second invasion he was slain.

A toilsome ride of six hours brought Dr. Grant to the house of the Malek. Both of his mules were lamed, and their shoes torn off among the rocks of the road. As no iron was to be had to replace the shoes, the Malek sent for a priest - the only per. son in the region adequate to the task - to transform his own ploughshare into the articles required. This matter settled, the doctor went to work on his patient, lanced an ulcer on his neck, and in ofher ways so far relieved him, that he pressed his physi- 
cian to accept the only respectable garment he possessed, and was grieved because he would not receive it. On Sabbath the doctor tried in vain to find either rest or retirement. He was searcely risen when the sick began to assemble. To send them away would not have been doing like his Master ; so he endeavored to minister at once to the body and the soul. To many, among the successive groups that met him that day in the upper chamber of the Malek, it was the last opportunity of hearing the truth as it is in Jesus. Other tidings already engrossed their thoughts; and their hearts failed them for fear, and for looking after those things that were coming upon them. A son of the emir was posted, with a party of soldiers, only one day distant, on the spot where his father had encamped the year before, seemingly to prevent coöperation between the tribes, and overawe the weaker till the stronger were subdued. Peace, too, was offered to the smaller tribes who would pay tribute.

Though this offer was not extended to Tyary, the Malek declared that he could make terms for that tribe also, if Mar Shimon would only come; and urged the doctor so strongly to send for him, that he began to fear all was not right. He learned, too, that the Malek had been told by the Kûrds that injury to his guest was a furor to them; and it was his interest to conciliate the lawless clans close by. In view of these things, Dr. Grant could not but think of the warnings of Mar Shimon. But all else was soon forgotten in the sad intelligence that the war had actually begun. The news at first was disbelieved, but too truly confirmed, as messenger after messenger arrived from the scene of action. The tribe of Diss, the home of the Patriarchal family, was laid waste. The blood of nearly eight hundred, of both sexes, had stained her valleys, and mingled with her mountain torrents. The leading men had been assassinated at a council to which they were invited to settle terms of peace, and then the whole tribe was overwhelmed. Neither sex nor age was spared. The survivors were hurried into slavery, 
except a small band, that still defended a mountain fastness against the mited hordes of Hakkary and Bûhtan. Says Dr. Grant: "The aged mother of Mar Shimon, whose kind eare for the pilgrim missionary comes up before me as a vision of yesterday, was slain, and her mangled body dragged to the river, her murderers exclaiming, as they threw it in, 'Go, carry the news to your accursed son!'

" His brother Zadok, too, who was so long the companion of my weary travels, - he, too, is slain; and, with him, his bright little boy, the expected successor of the Patriarch. He was a child of uncommon promise; and I can only think of his ruddy face as clothed in smiles. But his fair features touched no chord of pity in those savage hearts." Their mangled bodies were left unburied on the mountain side, with hundreds of others, that rendered the fatal spot too offensive to be approached by the survivors. The valuable library of the Patriarch, greatly diminished by previous invasions, was now destroyed. His three brothers and only sister were hurried into captivity. Weeping over the slain, yet unburied, weighed down with sad foreboding, they traversed the mountains in weariness and want. Of the household of the Malek of Diss, numbering about forty souls, but one eseaped to tell the tale. And yet this was but the opening scene in the tragedy. The storm that had burst with such fury on one place soon darkened the whole heavens.

Dr. Grant, that night, tried in vain to sleep; and morning brought a report of yet nearer dangers. Badir Khan Bey was on his way to atiack Tyary on the north-west, and the victorious troops hastened from Diss to meet him. On the south-east and south were hostile $K$ ûrds ; and, to complete the circle, a Turkish arny approached from the south-west. Thus were the Nestorians hopelessly hemmed in on every side; and the missionary, who had remained at his post till the very last moment, - feeble in body, but strong in faith, unmoved by danger while he could benefit the people whom he loved, - now reluctantly turned 
away. Had he known that this was his last visit to the mountains, he could not have stayed longer, or left more reluctantly. Of his many afflictions, perhaps this was the sorest. His checkered life could furnish no days so dark as these. Loug after, walking in the twilight on our roof at Mosul, with our premises full of the homeless fugitives, he remarked that when he turned to leave the mountains his heart was crushed. All that he heard and suffered afterward was nothing to the agony he then endured. Broken-hearted as he was, - for he suffered as though he witnessed the destruction of his own family, - there was not a moment to lose, and he set out at onee for Lezan. On the way he met a messenger from Mr. L., urging his immediate return; telling him that all his friends in Mosul, natives as well as others, were anxious for his safety. At Lezan the sad tidings were well known, but, according to oriental usage, carefully concealed from the Patriarch. He was still at Ashitha, vainly striving to send suecor to those forever beyond its reach. Want of time forbade Dr. Grant to go to meet him. He learned both his own bereavement and the departure of his friend from the messenger of the latter, and was utterly orerwhelmed; - the more so, as he regarded that departure as the harbinger of yet greater evils.

Dr. Grant left by the same road by which he first entered the mountains. The others were already occupied by the enemy; and, under God, it was only his intimate knowledge of the country that enabled him to escape. He spent the night with the aged Bishop of Dûree. He was the first to welcome him in 1839, and, strange as it may seem, from that day to this they had never met, till now he was the last to bid him farewell. The old man welcomed him to his house. The same shady walnut and pistachia terebinthus grew before the door. The same rill leaped down from the roeks above. It was the hour of evening prayer; and, while one repaired to the church under the cliff, bending over his crooked staff, and carrying the accus- 


tomed censer, the other retired among the rocks, that, alone, after the tumults of the day, he might commend a suffering people to his God.

A mountain-ridge was all that separated from the army of the pasha. He remembered too well the orders once given by that pasha for his head to linger near those ruffian mercenaries till the morning. So at midnight he departed; and, passing through Beita Noora (house of fire), roused some Jews from their sleep to aid his flight. The only other village on the road was deserted. He met only a few Nestorians, who preferred periling their lives, to secure their scanty erops, rather than perish of starvation, till he came in sight of Amadia, whence he reached Mosul on Saturday, July 15.

The plate represents the city as it appeared to him approaching from the ruins of ancient Nineveh.

Meanwhile the Kûrds, having destroyed Diss, and sent the eaptives into Bûhtan, united with the army under Badir Khan Bey and Khan Mahmûd. They then pushed on, by an unexpected ronte, to Chumba. Here most of the chief men fell in battle, if battle it may be called, where a handful of men fought against such overwhelming' odds. The Malek, on whom Mar Shimon chiefly relied, was among the first to fall. His death is thus described by Layard, I. 187 :

"After performing prodigies of valor, and heading his people in their defence of the pass which led into the upper districts, Malek Ismael, his thigh broken by a musket-ball, was carried by a few followers to a caveru in a secluded ravine; where he might have escaped the search of his enemies, had not a woman, to save her life, betrayed his retreat. He was dragged down the mountain with savage exultation, and brought before Badir Khan Bey. Here he fell upon the ground. 'Wherefore does the Infidel sit before me?' exclaimed the ferocious chief, who had seen his broken limb; ' and what dog is this that has dared to shed the blood of true believers?' - 'O, Mir,' replied Malek 
Ismael, stilı undaunted, and partly raising himself, 'this arm has taken the lives of nearly twenty Kûrds; and, had God spared me, as many more would have fallen by it!' Badir Khan Bey rose, and walked to the Zal making a sign to his attendants that they should bring the Malek to him. By his directions they held the Christian chief over the river, and, severing his head from his body with a dagger, cast them into the stream."

His wife was taken captive, with many others, while a few escaped across the Zab, and destroyed the bridge to prevent pursuit.

The Kundish host now followed down the western bank of the Zab, and crossed it at the renerable church of Mar Sawa. This they tried to demolish, burning what they could, and even destroying some of the massive masonry by gunpowder; but this was so difficult they soon desisted. It had two arched apartments, each ten feet by fifty. Only the northern of these was injured at its ends, and might readily be repaired, as it doubtless has been. This beautiful place now formed the head-quarters of Badir Khan Bey, as it had been the favorite resort of the Nestorians. Troops were sent out thence in every direction, to destroy the surrounding villages. The war was little more now than a succession of massacres. The Kûrds passed from place to place, slaying the people and burning the houses at their leisure, generally without even the shadow of resistance. The panic-struck Nestorians seemed alike incapable of flight or defence, and awaited in agonizing suspense their turn to suffer. One detachment pushed on to Serspidho; most of the men fled at their approach, leaving their wires and children to a horrid butchery. But forty brave men, in a small castle to the south of the village, like the band of Leonidas, stemmed tha tide of destruction, till only four of the forty remained alive. The village was then levelled with the ground, and one hun lred and 
sixty persons slain. Twenty deacons were reduced to five; and out of three priests only one survived.

I cannot forbear quoting here the description of our welcome to this village, in 1844, from the pen of Dr. Smith, it throws so much light on those traits in this people that interested the heart of Dr. Grant. He says: "Our host weleomed us to the flat roof of his house, and soon twenty men and as many women and children collected round, to wish us peace. I shall never forget, nor can I ever express, the feelings of that hour. Accustomed, ever since my arrival in the East, to be viewed with suspicion wherever I went, it was delightful, on the longlooked-for scene of my future labors, to find the people so kindly disposed toward strangers from a strange land, about whom they had only heard, through Dr. Grant, that they wished to devote themselves to their instruction. I felt that no light reason would induce me to leave so interesting a field; and I did not wonder Dr. Grant had been so zealous in urging the Board to maintain their ground."

But, to return to the war. Other parties perpetrated similar atrocities in other directions; and when Badir Khan Bey left the hitherto delightful valley of Mar Sawa, he left it scathed and desolate. Horses were stabled in this favorite church.* The shady bower near it was wantonly destroyed. The noble trees around it were girdled or cut down. The houses and mills in the vicinity were demolished, and such of their inmates as could not escape were slain.

An acre of arable land, a few sheep and goats, and rarely a cow, was a fair inventory of the resources of a mountaineer before the war. With these they could barely live; and many were forced even then to resort to more favored regions, to eke out

* Namel after one of twenty-eight monks, who came with Mar Ogin (Eugenius) from Egypt in the fourth century, and introduced into the East the asceticism which was then flourishing, in all its glory, in the Libyan desert, under the celebrated St. Anthony. 
the living they could not obtain at home. Now their flocks were taken away, their personal property plundered, their houses and crops destroyed, and even the trees, that might have helped to construct new dwellings, were cut down and chopped into lengths that rendered then useless for the purpose; so that, in such an inhospitable country, one was at a loss whether to mourn more for the living or the dead; for, stripped as they were, how could they remain in the mountains, and survive the winter?

While the rest of 'Tyary was thus desolate, the valley of Ashitha was untouched, according to the promise made to Dr. Grant. The Nestorians had thought that valley would be the first point of attack. But, contrary to all expectation, the rest of the district was laid waste, and that was spared, as if on purpose to disprove the calumny that the mission-house had been the oceasion of the invasion. Even the Patriarch was constrained to acknowledge that Badir Khan Bey had kept his word. He did more; he even restored to Dr. Grant some articles of personal property that fell in his way; and Mar Shimon attributed the safety of the whole valley to the Christian missionary, whose virtues had compelled the admiration and respect of the Kurds themselves. Yet, even in the valley of Ashitha, the Nestorians were partially disarmed. Many had fled, and a heavy tribute was assessed on those that remained.

But it is time to return to Mar Shimon, whom we left bemoaning his losses in Ashitha. Badir Khan Bey sent his brother Benjamin from Chumba, to summon him to surrender immediately, under the penalty of being slain wherever fomd. Instead of that, with this brother, Kasha Auraham, and others, - finding it impossible to escape into Persia, - he fled at once to Mosul, where he arrived a fortnight after Dr. Grant. As soon as the latter heard of his approach, he hastened to meet him, beyond the ruins of Nineveh. But how changed from the mountain chief he had left a few days before! It seemed as if years had passed, instead of days, and left on his features the traces of protracted 
suffering. Says Dr. Grant: "He said he had no definite plans, and at once accepted my invitation to make our house his home, at least till he should see the pasha. But presently we met Messrs. Rassam and Badger' and the former told me, 'It was arranged between him and the pasha that the Patriarch should be his guest. Moreover, he had instructions from the English government concerning him, and it was important he should be under the protection of the British flag." " Dr. Grant was sorry not to be able to show the same kindness to him, in his distress, that he had so often received from him in the mountains. But, at the same time, he did not wish to stand in the way of any political help the vice-consul might afford him. Nor did he wish to incur the blame of the failure of their plans. He rejoiced, too, in this opportunity of corroborating his oft-repeated declaration, that he had no political influence. Their plan of making Mar Shimon, the civil heal of the Nountain Nestorians, responsible directly to the Porte, he foresaw would not be easily carried out. The Porte would not be likely to alopt it; and, if it did, the Kûrds would not accede to it, without such coürcion as he knew would not be employed.

The account Mar Shimon gave of the distress in the mountains was truly affecting; and the Patriarch and the missionary often mingled their tears over the fate of their learest friends. The captives - consisting mostly of women and children - were many of them doomed to the alternative of the Koran or the sword. Women neither young nor handsome were butchered on the spot. Those too young to travel were killed, to save their captors trouble. Infants were tiken from their mothers' arms and dashed against the rocks, when carrying them prevented their keeping up with the rest. In $18+4$, we found the skeleton of a child, bleaching by the side of a spring on the mountain behind Ashitha, slain there, or left to peri h, because its weary limbs could go no further. A party of these captives, crossing the Zab, threw themselves from the middle of the bridge, and perisbed, rather than 
endure the fate before them. Others leaped into the Tigris at Jezira, preferring death to such a bonlage. Both the French and English consuls sought to procure their release. But the pasha pretended that Batlir Khan Bey had acted under orders from Erzrûm, and so evaded the matter, thongh his own army, on the southern border of Tyary, cöperated with Budir Khan Bey, from whom he had received some two thousand sheep, as his share of the spoils, and he himself had forcibly taken from the Nestorians all the lands they possessed in Berwer.

If the captives were to be pitied, those who remained in the mountains fared but little better. After the slaughter, the remaining tribes sent in their submission, and were spared, for the sake of the revenue they might afford the conquerors. They were subject to ummeasured oppression. The half of their crops, next season, was claimed by the Kûrds; and their lives were in constant danger from those who deemed it an act of charity to kill a Christian dog. The day before Dr. Smith and Mr. L. reached Ashitha, in August, 1844, one man wask killed in Lezan, by Kûrds from Berwer. A few diys after, another was killed, and a third wounded. Fifty sheep were taken from Matha 'd Kasra, by Kûrds from Chull; and, two days before we left the mountains, three hundred men were sent by the emir to take a hundred and fifty sheep from Berawola, - the only flock of any size remaining in 'Tyary. This involved more than the mere loss of property. When we descended to the village, women were wailing for the dead, and men were beating their breasts. The troop had attacked them in the night, killed the shepherd, and were driving off the whole flock, when the villagers rushed to the rescue. Two more of their number were slain in the mêlée, and three of the invaders were left stark and stiff on the hill-side. The rest fled, leaving their booty and bearing off their bleeding comrades. Never can we forget the impression made by those three bodies lying naked and unburied where they fell. One was an old man, his gray beard clotted 
with. gore, his glaring eye-balls vainly turned to heaven, and his bodf covered with ghastly wounds. Another was a beardless youth, and a large gunshot wound in his breast showed too plainly how he fell. The third had been shot, and then de. spatched by repeated stabs of their daggers. The sight gave us a more vivid impresion of the horrors of war than the descriptions of all the battles we had ever read.

It was near sunset. The winl swept moaning by, as we rode along the bleak rilge of the nountain. The neighboring villages were deserted. In one home the cradle was left, and a dog, the only living thing remining, howled at us as we passed. In the valley below, they had killed a priest, as he lay on a sick bed, unable to escape with the rest. Parties met us at every turn fleeing, and yet not knowing where to flee for safety. After nine o'clock, we passed through the midst of fumilies sleeping in the road on the bare rocks. From the bottom of the glen, in the cloudy noonlight, we could see crowds ereeping along the ledges high above us, and so it continued till we stopped at midnight. This was a sad picture of the perils of the suffering remnint; but was only too true a representation of their condition ever since the war. It seemed as if, without leaders, without union, and without arms, they were doomed to utter externination.

But, anid all their sufferings, it was interesting to see their strong attachment to their churches and sacred books. One, who had lost a greater anomut thin most possessed, grieved more for the destruction of the village chureh than for the utter desolation round about it. Sone of their books were concealed, and more would have been, but that they feared to bury them, lest dampness should prove as injurious as the Kurds.

Though Badir Khan Bey scrupulously kept his promise to Dr. Grant, yet Zeiner Bey, whom he left Governor of Tyary, with four hunthed soldiers to support him, took possession of the mission-house. But the mpretending structure was altogethe: 
unsuited to his purpose. The Kûrdich robber dared not trust himself in such a dwelling as had heen built for men of peace. The large windows were huilt up, and in their stead loop-holes threatened death to the assilant. Lime was subtituted for mud. The walls were rative an additional story, and round towers of still more sulst:antial structure were erected at the corners. Everything sarored as much of war and force, as before of peace and love.

The ferocious Zeiner Bey, irritated by the attack of Mar Shimon in the spring, with troops from this village, was not very gentle in his govermment. The Nestorians bore this very patiently, till, in Octoher, they made an ill-judged attack on the castle. If their leaders har heen worthy of the courage of the troops, the garrison lad been utterly destroyed. But they were lel by Shematha (deacon) Hinno, of Lezan, who had gone over to Badir Khan Bey before the invasion, and Kasha Jindo, of Salaberka, who had sided with the enir. The Nestorians from all quarter's joined the beriegers; and, ar 'Zeiner Bey was entirely unprepared for a siege, his men were soon without food or water. In this strait, he called Shemasha Himno to the door, and told him he could hold ont no longer ; but, as there was much property in the castle, and it was a pity it should be dispersed among the rabble, he proposed to deliver it all to him, on condition that his men were allowed to depart unmolested. The credulous deacon swallowed the hait, and was soon hoisted up to the flat roof to receive the boty. But, no sooner had he reached it than "zeiner Bey denanded lisal and water or his life, and the greedy coward at once aceoled to the remand. Mis men blindly obeyed his orters, and the Kurds had a plentiful suply of all they wanted. The conflict was now renewe? with greater fury. But a cietachment ent by Badir Khan Bey to the relief of the garrison soon arrived; and the Netorians, attacked on both sides, were routed with great slaughter. No quarter was given. 
Shemasha Hinno was impaled within the castle, and Kasha Jindo was put to death by the emir in Julamerk.

When tre Nestorians fled, they set fire to our chapel, which was outsid s the castle, vainly hoping to involve their enemies in the conflagration; and, to avoid a similar occurrence, Zeiner Bey destroyed all the outbuildings, learing the castle entirely alone. A large reservoir was also excavated within its walls, and well stocked with snow and water. The soldiers now swept through the ralley as far as the Zab, sparing neither age nor sex. Ont of three humdred houses in Ashitha, only four were left unburnel. Learning from the fugitives the fate that awaited them, the inhabitants of Minyanish and Lezan fled to a cave high up in the mountain, to the north of the valley. Women and children, as well as men, climbed to a place almost inaccessible; and the Kards, unable to follow, ent off all supplies. In three days their water and provisions failed. The weather was hot, and they offered to capitulate. Zeiner Bey swore on the Koran to spare their lives, on condition they surrendered their arms. But, no sooner was this done, than the Kûrds connmenced an indiscriminate slaughter, till, tired of butchering, and knee-deep in blood and mangled carcasses, they forced the rest, at the point of the dagger, to leap down the precipice on the rocks below. Out of, according to some, fourteen hundred souls, but at least as many as a thousand, not one - or, following another report, only one - escaped. Mr. Layard visited the spot in 1846 , and it is thus deseribed by his graphic pen:

"Emerging from the gardens, we found ourselves at the foot of an almost perp ndicular detritus of loose stones, terminated, about one thousand feet above us, by a wall of lofty rocks. Up this ascent we toiled for above an hour; sometimes clinging to small shrubs, whose roots scarcely reached the scanty soil below; at others, crawling on our hands and knees; crossing the gulleys to secure a footing, or carried down by the stones which we put in motion as we advanced. We soon saw eridences of the 
slaughter. At first, a solitary skull rolling down with the rubbish; then heaps of blanched bones; further up, fragments of rotting garments. Aswe advanced, these remains became more frequent, - skeletons, almost entire, still hung to the dwarf shrubs. I was soon compelled to renounce an attempt to count them. As we approached the wall of rock, the declivity becamic covered with bones, mingled with the long platted tresses of the women, shreds of discolored linen, and well-worn shoes. There were skalls of all ages, from the child unborn to the toothless old man. We conld not avoid treading on the bones as we adranced, and rolling them with the loose stones into the valley below. 'This is nothing,' exclaimed my guite, who observed me gazing with wonder on these miserable heaps; " they are but the remains of those who were thrown from above, or sought to escape the sword by jumping from the rock. Follow me!' He sprang upon a ledge rumning along the precipice that rose before us, and clambered along the face of the mountain overhanging the Zab, now scarcely visible at our feet. I followed him as well as I was able to some distance; but, when the ledge became searcely broader than my hand, and frequently disappeared for three or four feet altogether, I could no longer advance. I was still suffering severely from the kick received in my leg four days before, and was compelled to return, after catching a glimpse of an open recess or platform covered with human remains."

This done, Zeiner Bey had now free opportunity for revenge ; and he inflicted it without mercy. The story of his cruelties will never perish from the legends of the Nestorians. He stripped the people of everything, torturing, and even slaying, those who resisted. His men ransacked the mountains for buried provisions, and many a family lost the last handful of millet they had secreted in pits and caves.

In 1844 we saw those who had lost the use of their arms by the inhuman twisting of the cords that bound them bohind the: 
backs. Some lost the use of their legs by similar cruelties. Others had their breasts burned with red-hot irons, or were suspended by hooks thrust into the muscles of their arms and legs, till they revealed every hoard they knew of, and even after there was no more to reveal.

Other modes of torture night be mentioned, but they are too horrid for recital. These may suffice to show that the suflerings of the Nestorians were by no means so light as some seem to suppose. Could Tamerlane have lone worse, when he drove their ancestors to these very strongholds, now stained with the blood of their children? These atrocities called forth such a protest from the European political agents, that 'zeiner Bey was recalled, and his brother sent in his room, but without any change for the better. Indeel, he proved himself every way worthy of such a brother.

Many of the Nestorians fled to Berwer, only to be betrayed to the invaders, or slain in revenge for previons injuries. This was the last great slaughter during the life of Dr. Grant, though murders and robberies on a smaller scale still continued. Zawithah, through the prudent management of its principal men, eseaped the fate that orertook all the rest of the valley; so that, in 1844, we found it comparatively uninjured, and the only place in the vicinity that could furnish supplies to the starving garrison of Ashitha. Dr. Smith was moved by the situation of these Kûrds. He writes thus in his journal: "Poor men! with nothing to do but to watch over the ruins of a once prosperous village, that they themselves have destroyed. Meeting no one without their own gloomy circle but those whose hearts are full of vengeance, their lot is pitiable indeed. Night after night they pace the battlements of their castle, and utter their wateh-cry to the surrounding hills. But no comforts of life none from society, none from home, none from their own consciences - cheer their lonely hours. Poor men! I pitied them so much I could not hate them, though I knew that, less than a 
year ago, they made one another sport by throwing up Nestorian infants, and receiving them as they fell on the points of their daggers." They had only enough sent them to supply them with barley-soup for two days in the week; the rest they were expected to plunder from the Nestorians. The eggs they cooked for us in the morning were brought from Berwer; and in the afternoon the remainder was warmed over again, as they had absolutely nothing clse to set before us, so miserable were the plunderer', as well as the plundered.

In the autumn of $18 \pm 0$, Tehoma shared the fate it had helped to inflict on Tyary. Badir Khan Bey was the instrument of this terrible retribution. The women were brought before him, and murdered where they stood, that there might be no more redeeming of captives. Three hundred of them, fleeing to Bass, were eut off in the pass leading to that district. The villages were destroyed, and the church pulled down. One-half of the population is said to have perished. One of the Maleks and Kasha Bodaca were among the slain. As soon as the fugitives returned, they were attacked by the emir. Many died under the tortures he inflicted to compel them to disclose the treasures he fancied they had concealed; and others fled into Persia.

It is difficult to determine with aecuracy the whole number that perished, in the different massacres. Many Kûrds were killed, as well as Nestorians. But Dr. Smith, who was very careful and accurate in his estimates, set down the population of the mountains, before the war, at fifty thousand. Dr. Grant at first called it one hundred thousand, but afterwards made a lower estiniate. At the time we passed through the mountains (September, 1814), there were not one hundred habitable houses in all Tyary; and, leaving out Ashitha, which was almost wholly destroyed, the ruins were to the houses as six to one. In Diss things were much worse than eren that. The houses we found had mostly been rebuilt since the war; and 
as, owing to their scarcity, one contained three or four times as many inhabitants as formerly, he estimated the entire loss of population by the war, up to that time, at not less than ten thousand, or one-fifth of the whole. This was more than a year after the first massacre, and ten months after the second, when many of the fugitives had returned to their former homes. Dr. Perkins estimates the number of the slain in Tehoma, in 1846, at seven hundred; but Mr. Layard says that from four villages alone seven hundred and seventy had perished.

This district is called by the Kûrds Tehoby, and the Syriac name would be, perhaps, more accurately represented by "Tekhoma" than by the more easily pronounced Tehoma. 


\section{I A P T E R X VIII.}

COURTESY BETWEEN MISSIONARY SOCIETIES - LETTERS OF DR, GRAN $\mathrm{C}$ - IIS PROPOSITION - LABORS AMONG TIIE JACOBITES - MICHA - NR. BADGER - DR. GRANT EXONERATES IIH Fron A FALSE CHARGE - MLAR SHIMON - EVIL OVERRULED FOR GOOD - BIBLE Class - ANOTHER BEREAVEMENT - REBUKE FOR SYMPATHY - IEATII OF PASHA - IOSPITALITY TO REFUGEES - DEATHS AMONG THEM - DJFFICULTY ABOUT BURIAL - DR. A. SHITI - IIS JOURNEY - CHARACTERISTICS - HIS LETTER ON "ORGANIZATION.",

Havivg dwelt so long on the war, so as not to be eompelled to recur again to the painful topic, let us now return to Dr. Grant in Mosul. From the first he had urged the permanent oecupation of this station, and each of his associates, as they arrived, had seconded his plea. But the committee at home, true to their principle of non-interference with other missionary societies, resolutely refused. In their instructions to Mr. L. in 1842, they had said, "Ourstation in Mosul is merely an outpost, and we hope the necessity for it may be but temporary. We have no intention of sending a mission to the Jacobite Syrians, since we acknowledge the claim of our Episcopal brethren to the exclusive possession of that field. The relations of Mosul, in a missionary point of view, to both these branches of the Syrian whrch, are similar; and, like Calcutta, Singapore and other great centres, it may be regarded as common ground ; and to these principles they adhered to the very last. If any other society interferes with the fields occupied by the American Board, one thing is certain, it is not in retaliation for a similar offence.

Under the apprehension that, owing to the disasters in the mountains, and this restriction laid on missionary labor in Mosul, 
the mission might be broken up, Dr. Grant writes to a friend, October 24: "I am not anxious about it. I am ready to go anywhere, or do any thing. God is my witness, that I have not spared myself, nor shrunk from any trials, in seeking to promote his canse. To Him I leave the entire disposal of my future course." Well might he enjoy this testimony of a couscience void of offence. Few men in like circumstances ever had a better claim to it, or could appeal more honestly to the Searcher of hearts.

That this readiness to go anywhere or do anything was not mere words will appear from the following letter to Dr. Anderson, written a month previous: "In the present state of things, what shall we do? The Nestorians cam no longer protect us. Under God, the missionary must throw himself on the inerey of the Kûrds, counting not his life dear unto himself. At the risk, perhaps, of being deemed insane, I have already suggested seeking the protection of the emir, as the only feasible means of safety in further labors in the mountains, though that is not altogether safe. Since that time he has written to me, and invites me to return to the mountains, promising to provide me a residence wherever I desire it. I have trusted him, and perhaps may still trust him. But, when I remember how he has plotted against me, while professing to be my friend, I feel it is better to trust in the Lord than to put confidence in princes. This trust has never failed me in the darkest hour. And, after so many and so signal interpositions of God for my deliverance, I sometimes feel an almost invincible confidence in the greatest perils. But I may not hope the hand of violence will always be restrained. And, should my blood stain the dagger of the assassin, what would then be the verdict of those who sent me forth? That I have fallen as their messenger, for Christ's sake, in the faithful discharge of the trust committed to me, -- or the victim of my own unwarrantable rashuess? Will they sustain me in returning thus to the mountains? If so, I am ready to go, and superintend native helpers from Oroomiah, distribute books, 
establish schools, and labor as God shall give me opportunity. But, when I have already incurred the charge of ' courting death at every step,' it is proper I should hear the voice of the church before incurring new and greater dangers. I look to you, as their organ, for an answer." Still later, he wrote as follows :

"Iy privations in the mountains, many of them, were peculiar to a pioneer in such a field, and could not be detailed without an appearance of boasting that ill beeomes a follower of Him who laid down his life for the sheep. To return there is in no ways inviting to fich and blood. All the romance of that field - if there crer were any - is now sober reality. There is no poetry in winding your. weary way over rocks and cliffs, drifted snows or dasing torrents. Neither is there any in appeasing hunger firm their dirty wooden bowls or still fouler goat-skins, while tormented with moke, insects, vermin, and a thousand nameless trials, among an impoverished and lawless people.

"Families cannot live in the existing insecurity. The work, if resumed, must be ' in journeyings oft, in perils of water's, in perils of robbers, in perils in the wilderness, in perils by false brethren, in weariness and painfulness, in hunger and thirst, in fastings often, in cold and nakedness.' There is no coloring in this. These nust be met, or the field abandoned. No half-way measure will meet the cace. I have no hope that the Porte will ever be able to shicid the missionary, even if so disposed. He must cast himself, under God, oil the Kûrdish chiefs themselves, and by his scrvices make them fcel that his life is more profitable to them than his death. Still, a physician would not always be able to save life; and the fate of the papal missionary in Jezira shows what he may expect, in that case. But must we shun danger when in the path of duty? Did Christ intend we should, wher he sent forth his disciples, as sheep anid wolves, and charged them not to fear them who can kill the body?

"But you will tell me that, should we fall, the mission mill suffer in public sstimation. 1 kinw it may, and our nanes tos he 
cast out as evil. I have sometimes been ready to shrink from danger, feeling that the churches would condem me for exposing life. Not that I would expose it rashly - God forbid! Life is a solemn trust, given to be used for the glory of Christ on earth, and for that patiently employed, till God see fit to take our armor off and bid us rest. But is the church so truly conseerated to Christ as to make its voice a safe index of duty where peril is involved?

"I frankly confess that, when in peril, the thought that, should I fall, many will only say, 'I told you so', and hand down my dishonored memory as the only heritage of my childien, and an injury to the cause of Christ, has caused me much distress. But be it so. I had rather go to judgment with the approval of God, and the frown of the world, than, for the sake of a gook name among men, meet that Judge, conscious of having hetrayed my trust. There is meaning in those words of Christ, 'Whosoever shall save his life shall lose it.' There is such a thing as falling into danger when fleeing from it in the path of duty."

In a letter, dated November 20th, he pleaded that the mission might be made "a mission to Assyria and Mesopotamia, and not to any particular sect;" the very thing that has since been done, with so much suecess.

Though the mission was not at liberty to undertake any regular system of operations among the Jacobites, yet they conkl not refuse to give instruction when asked; for a higher authority bade them "do good as they had opportunity to all men." The pleasant impression left by Mr. Hinsdale, joined to the labors of Bishop Athanasius and the medical practice of Dr. Grant, brought us many visitors; and not a few came inquiring for the truth. This led Mr. L. to the sturly of the Arabic, and, for a time, he conversed with them through Mieha, as best he could. Never can he forget the first time he spoke with this man of the great love wherewith Christ hath loved us. It was 
on the Sabbath. They were seated alone in an npler room; and, as the missionary spoke of the fulness and freeness of redeeming love, his hearer eagerly devoured every word, diawing nearer as his interest increased, till, grasping him by the hand, he exclaimed, "Do come with me into the houses of the people and repeat these good words, and I will interpret them to all; for they never heard such things before." It was pleasant to witness the good will to man, so characteristic of the young convert at home; and fiom that time Micha took great delight in explaining the truth to all that came.

Finding the influence he was thus exerting, Mr. Badger sought to demive us of his services; and, to this end, represented us to him as out of the charch, without a ministry, or any requisite of discipleship. He plied him with ecrlesiastical history viewed from the high-church stand-point, and affectionately warmed him of the mischief that he, the nember of an apostolical church, was doing, in introducing heresy and schism within its pale. Micha had not read mach church history, but he had read the Bible, and read it to purpose; and nothing could shake his confidence in those who had pointed him to its blessed truths. Flattery was tried, but with no better success. Threats were next resorted to, and he was actually denounced to the bishop, then in Constantinople. The latter wrote, advising him to leave us; but, in reply, received such a faithiul cpistle, backed by such a formidable array of proof-texts, that he was glad to let him alone. At the same time, he was pointed out to the leading Jacobites in Mosul as a youth of pronise, who was ler astray by hereties, and likely to do much harm to the church. But this only gave him an opportunity for faithful personal conversation with them; and here too $\mathrm{Mr}$. Badger was baffled. He next tried a method few in that region eould have resisted. He offered him double wages. But Micha spumed the bribe, telling him he was with the Americans, not for their money, but secause he loved the truth they taught. Justice requires me to 
add, that this last mode of attack was never nentioned hy him, though the others were, and we only heard of it months after the occurreuce, through another party. When, owing to his increased proficiency in English, we raised his wages from one hundred piastres (four dollars and thirty-three cents) a month to one hundred and fifty, even then he was with difficulty induced to aceept it; asking, with tears, whether we doubted his attachment to the trith as it is in desus.

As regards the whole course of Mr. Badger, our instructions from the Prudential Committee had told us, "If the Episcopal churches of Lingland or America choose to open a friendly correspondence with the Nestorians, you will not interfere in any way. Mere diplomatic missions to the oriental churches will be of short continance. Let it be your aim to abstain from all ecclestastical or missionary diplomicy, and quietly pursue your grand spiritual object, - the revivil of the knowledge and power of the gospel among the people."

One of the excellent Secretaries of the Board - the Rev. D. Greene - wrote to us as follows: "As to the troubles your" neighbor occasions you, in your patience ye must possess your souls. Pity him - pray for him; and by your example show him a more extellent way. As these things must, some time or other, be known and judged of, - at the judgment-day, at latest, - we beg of you to aroid everything reproachful, or that, to any candid person, would ceem dishonorable to the spirit of Chint. Do not lose your good-nature or quictness of spirit. Expect little, and then you will not be disappointed if you get little. Determine that you will yourselves honestly serve God in the gospel, and let others serve their idol of a church, if they will. But do not let their errors, or trickery, or bad spirit, prevent your cherishing the meekness of Christ."

I cannot better describe the feelings or conduct of Dr. Grant, in the case, than by turing the imperative of these quotations into the historic past: 
His letter of October 16 to the New Jork Observer, on the causes of the war, though it, perhaps, makes the emir too subordinate, and ascribes the invasion too exchisely to the Turks, yet presents such a truthful picture of his whole conduct in the matter now before us, that it is here inserted nearly in full. It was written to defend Mr. Badger firm the unjust charges of members of his own church, when the man thus defendel had not only repelled with scom every effort of Dr. Grant to live in peace, but had not even entered the house for months. It was penned, too, as soon as M. Botta pointed ous the article in a French paper, and when he had to get anotler to translate it. Nor will the reader forget that this defence of his opposer was made when there was not the least necessi y for self-defence, as the article in question expressly stated that "the American missionaries were exempt from blame."

"The late war in Kurdistan, which has resulted in the subjugation of the Mountain Nestorians, appears to be rery imperfectly understood.

"In the Journal des Debats of September 8 , we find a letter from the Constantinople correspondent of the London Globe, charging the whole affair to "the religious quarrels of the independent Americans, the English Puseyites, and the French Catholics.' This is too grave a charge to pass unnoticed; and I feel less reluctant to state the facts in the case, since the writer has frankly arowed that 'justice requires it to be stated that, in this affair, the American missionaries are exempt from blame.' Perhaps I cannot better do justice to the whole subject than by presenting a brief account of the origin and progress of the late calamities of the unfortunate Nestorians. From the watch-word of Islam — 'The Koran, tribute, or the sword' - it may well be inferred that the existence of a body of nominal Christians, who have for centuries resisted each of these demands, has been a reproach which 'the faithful' wewe eager to wipe away. But 
this was difficult to effect, as their victims were defended by the double rampart of almost impassable mountains and unsubdued tribes of Kûrds, - these last too much divided among themselves to attempt the conquest of their neighbors. At length, Reschid Pasha so far subdued the Kûrds that the Turks hoped to make them efficient agents in the work; and, on my first visit to this city, in 1839, I found the pasha eager to go against the Nestorians, having extendent his sway to the very borders of their country. And on ny return to Julamerk, in 18t0, Nûrûllah Bey had gone to form an alliance with the Pasha of Frzrum, his principal object being the subjugation of the independent Nestorians, living. as they did, within the nominal bounds of that pashalic.

"On my way to Constantinople, I met this chief at $\mathrm{Van}$, with a new pasha of that place, who had been sent with immediate reference to this end, of which, indeed, he male no seeret.

"At the same time, the Pasha of Mosul had marcher to Ama. dia, with ultimate reference to the Nestorians. Mr. Ainsworth, writing from that place, on the very day that I left Van, says: 'This day he pitched his tents within a mile of the town; and greatly did the officers rejoice at what they deemed certain, the immediate subjugation of the Nestorian mountaineers.' - Ainsworth, vol. II. p. 203.

"Thus the matter stood when I went to Anerica; and hence it was not without reason that I said, "The Nestorians were, perhaps, never in more danger than now of being subdued by the Turks, who have pushed their conquests to the very borders of their mountain-home; and into that, I have good reason to believe, they intend to penetrate.' - Nestorians, \&.c. p. 321.

"On ny retuin to the East, in 1841, I found that these plans had been delayed by the removal of Hafiz Pasha from Erzrûm, the death of the Waly of $\mathrm{Van}$, and the sudden recall of the Pasha of Mosul, to drive back the Persians from Sulimanieh. Yet the plan was not abandoned; and the Hakkary chief had already gone to obtain assistance from Badir Khan Bey, who 
proved the most efficient agent in the late invasion. The united forces of these chiefs made a descent upon Diss, burned the Patriarch's house, and retired without molesting the more powerful tribes. The blow, however, was one from which the Nestorians never recovered, and, hy weakening their courage and dividing their counsels, did much to prepare the way for their final downfall. Indeel, from that time, the Hakkary chief claimed their whole country as his own.

"Late in the autumn of 1841, the Pasha of Mosul sent an army against them, which returned, however, without effecting anything, owing to the severity of the weather. The Nesturians then took their revenge, by ravaging the neighboring villages of the pasha, while the latter consoled himself with forming more efficient plans for the ensuing spring. These again were frustrated by a revolt of the Kûrds, and the temporary loss of .Amadia. The Pasha of Erzrûm was, at the same time, engaged in the threatened war with Persia; so that no progress was made last year towards the desired result. During this per.od I reëntered the mountains from Persia, and obtained the official permission of the emir to build houses in Ashitha, where, in September last, I commenced the erection of a house, in the judgment of myself and associates barely sufficient to accommodate the mission families and a school. It was built by native workmen, in the style of their own dwellings, with rough stones, picked up from the surface of the ground, and laid in mud; and the walls were neither higher nor thicker than many of the native dwellings.

"In October a missionary associate arrived in the mountains; and, shortly after, a Roman Catholic missionary visited the Patriarch, with whom we were then staying; but he soon returned, without an unpleasant word passing between us. Since that time he has been more than once under my professional care in this city, as well as some of his associates, and I may safely say that all our intercourse has heen in strict accordance 
with the apostolic injunction, 'Be courteous,' however widely we differ in religious opinion; while the worthy consul of France, whose protection they enjoy, we are happy to number among our best personal friends. If such has not been, in all respects, the character of our relations with 'the English Puseyites,' it is a solitary exception to the most friendly relations which we have sustained with all other English gentlemen whose acquaintance we have had the pleasure of making in the East; and the fault must rest where the correspondent of the Globe has laid it. I have attended upon them in sickness; and both I and my associate have sought, by every proper means, to cultivate a firiendly relation - conscientiously a voiding to speak against them, under any prorocation. If we have failed, the responsibility must rest with Mr. Badger for any evil arising from his opposition to us. But, certainly the late disasters of the Nestorians had no connection with such a cause.

"These facts clearly show that no act of either English, French or Americans, could have been the occasion of the late invasion. The origin of that lies in other events, of a much earlier date. The testimony of Mr. Ainsworth dates more than two years prior to the entrance of either the English or French, or the commencement of our building in the mountains. The burning of the Patriarch's house, in 1841 , was a year previous to these erents; and the representatives of the British government at Constantinople, Erzrûm, Mosul, Bagdad and the court of Persia, can furnish evidence of the danger to which the Nestorians have been exposed, from that day to the present.

"It is well known that, in these countries, it is never difficult to get up a report, however incredible, and support it with the most barefaced effrontery. A case is at hand precisely parallel to the rumor of our own castle-building. M. Botta built a small house, of sun-dried brick, to shelter himself while prosecuting his researches at Khorsabad, and our pasha has complained that he has built a large castle, - making representations as 
extravagant and unfounded as in our own case. In both instanees there was written permission to build; and the document giving permission, in our own case, may be seen in the U.S. Legation, Constantinople, bearing the official seal of the Hakkary chief, and endorsed and sealed by Mar Shimon. Besides this, I have lately received a private letter from the same chief, inviting me to return and reside in the mountains, pledging me his aid and protection, with assurances of unaltered confidence. Similar professions were made by Badir Khan Bey, on ny visit to him at Dergûleh. And the Pasha of Mosul, after sending his complaints to the capital, so far from opposing, gave us his official protection on our return to the mountains for the present year. These are not the acts of men who believe their own evil reports, the true object of which this is not the time nor place to investigate."

Well might the editor write, in forwarding the above: "The letter itself is a noble one; but, when you contemplate a man pausing in the midst of pressing duties to defend the enemies of his mission against attacks made on them thousands of miles off, I think you will see a trait of character as rare as it is beautiful and Christ-like.

"I have always regarded Dr. Grant as an extraordinary man; and, in a long editorial life, in which it has been my constant duty to observe the progress of error and truth in the world, I have never met with an instance that equals this, in true Christian prineiple and magnanimity. I therefore shall feel a peculiar pleasure in seeing it recorded, making true the words of the poet,

\section{'Only the actions of the just}

Smell sweet, and blossom in the dust.' ",

Mar Shimon now expected to realize at once the bright visions of political help held up before him by his new friends. But weeks and months passed away, and his impatience deepened 
into a settled melancholy. Accustomed to the bracing air of the mountuins, he pined away in one of the hottest cities of Mesopotamia, distressed by the past, and despairing for the future. But all this time Dr. Grant never alluded to the failure of the plins already mentioned. Not a word did he utter to the detriment of his opposer; he rather encouraged the drooping spirits of the Patriarch, and bade him still hope on. Above all, he sought to. have him look mp to God, who permitted these trials for the gool of His people, and wait for his deliverance. Often, as they talked together, his voice would falter, and tears mingle with his consolations.

The getting the Patriarch away from Dr. Grant, as already related, relieved the mission of a considerable expenditure it would otherwise have been dificult to avcid, as he remained in Mosul till after the defeat and capture of Badir Khan Bey and the emir by the Turks; and, besides convincing Mar Shimon himself of the truth of Dr. Grant's repeated assertions, that he had neither political aims nor infuence, it satisfied the Turkish anthorities of our neutrality in politics, and so impressed even the Moslems with the strictly religious nature of our mission, that, in the following summer, when a mob tore down the papal church, then in process of erection, and wounded one of the padres, we were the only Franks that could walk the streets without insult, and were treated with more than usual attention, even though Dr. Smith was then in attendance on the wounded priest.

Dr. Grant now devoted his time to doing good in Mosul, as well as to efforts for the benefit of the suffering Nestorians. These last were not confined to strictly missionary operations. As soon as he heard that the only sister of Mar Shimon, and one of his brothers, were captives at Julamerk, he sent his servant to negotiate their ransom. Fortunately, they had just made their escape before the messenger arrived; and the emi: was 
profuse in declarations of what he would have done fir his friend when it was out of his power to do it.

Meanwhile, owing to the extreme heat, and other intermptions, the progress of Mr. L. in Arabic was but slow; yet, no sooner was he known to be thus engaged, than numbers of the Jacobites came, earnestly desiring religious instruction. What could he do? He was not at liberty to do anything that involved expenditure. But it refuired no outlity to instruct a few young men in the Bible; and they were therefore requested to meet him at a given hour on the Subbath. Thus commenced a Bibleelass, which was maintained, with few interruptions, till the mission was broken up. The work was very difficult at first, as he had only given some three months to the study of the language; but, believing that scripture is its own best interpreter, the text in hand was explained by a copious quotation of parallel passages, and questions were answered by referring the inquirer to some verse that expressed the thing he sought. Thus, by the aid of Micha, and their own interest in the matter, he succeeded fur beyond his hopes. The attendance gradually increased, though it never rose much above twenty. More questions were asked. The exercise became more interesting; aud, from the necessity of the case, the Bible was the standard of appeal, and the decision of each question was in the language of the Holy Ghost.

Presented even in this imperfect way, the tearful eye often witnessed to the yower of the truth; and nothing moved the hearts of that little company more than the views of Christ presented in the gospel. They had been taught to look on him as a being enthroned at an infinite distance, and accessible only through other intercessors; and therefore, when they heard him say "Whosoever shall do the will of my Father which is in heaven, the same is my brother and sister and mother," they seemed to enter into a new world. Words cannot express the delight of unfolding truth like this to such hearers, and eternity 
alone will diselose the results. The plainest practical remarks seemed to fall on their ears as if fresh from heaven. One young man, who gave twenty piastres for a Syriac Bible, before our coning, when he found that le was too late one Sabbath for the Bible-elass, declared he had rather spend the night in the house than lose it again; and next Sabbath saw him there an hour or two before the time. Another, who was reading the Bible to one of the females of his family, was frightened, and lesisted, as she burst into tears, saying, "If that be true, our ways are crooked ways. What shall we do?" It was a result of the truth he had not looked for. The sister of one of the young men learned to read, and used to read the gospel to her neighbors when they called. She also longed to be able to teach a school for girls.

Thus much the writer may be allowed to say, that no portion of his life ever yielded such happiness as the hours spent with that little Bible-class on the banks of the Tigris; and nowhere does memory revert with such unalloyed delight as to that loved scene of labor for his Redeemer.

There were other things not so pleasant, - opposition amounting sometimes even to perseention, accusations before the kadi, and spies set to watch, and report those who attended. There was one deacon, too, more learned than most, who loved nothing so much as to dispute. He was hot and hasty withal, and generally was no sooner seated than he plunged into some "questio vexata" of his church. The effort to lead to more practical riews of truth was soon abandoned, in despair. A torrent of Arabic terms in theology, utterly unintelligible to the missionary, swept away every endeavor to reply, and left no other resource bat silence, or a confession of ignorance as to his meaning, that was set down as ignorance of the point in debate.

In December the mission was again afficted, in the death of Mrs. L. She was a pupil of Miss Grant and Miss Lyon, at Ips- 
wich; and, after leaving the seminary, her lore of doing good would not allow hor to be inactive, and she taught a private school of young ladies, loving and belove? by all who knew her. Her class in Sabbeth-school hat no reason to complain of her absence, or of want of interest in the leson as explained by their teacher. She delighted in the seriptures, and never was hapier than when, alone in her rom, for hours she communed with God through the pages of his work. And yet, a deeply did she feel for those who had not yet learned the truth as it is in Jesus, that she once expresced to a friend her fears lest such enjoyment was selfich while o much was to be done for others. And when, in May, she was asked whether she was willing to return with Mr. L. to the mountains, the prospect of gathering a few of her own sex, and teaching them the way of salvation through Christ, seemed to cover up all the privation and peril of the attempt. A home, even in a border-village of the mountains, where she might engage in active missionary work, had for her greater attractions than the comparative comfort and safety of Mosul, where we were so shut out from labor. In September she expressed a sense of unusual enjoyment in spiritual things. Little did we think it was the Master preparing her to depart. Even she herself may not have understood the meaning of those clear views of the loveliness of Christ, and that child-like fiath in the riches of his grace. But does the Good Shepherd ever call a believer home whom he does not prepare for the change?

During October and Norember she gradually grew weak, under a distressing disorder, with symptoms, writes Dr. Grant, strongly resembling " quick consumption," till, at last, after fifty hours of agony such as her physician pronounced the most painful and protracter he bad witnessed in a practice of fifteen years, she sweetly fell asleep in Jesus. During all that sore distress we could only look on and adore the grace of God. In her severest sufferings she manifested the utmost patience. Sho 
spoke with difficulty, every sentence cut short by pain; yet she never addressed one of us without using the terms "dear," "kind," "sweet," or similar expressions. During her greatest distress one of us sat constantly at the bed-side, holding her hand in ours. The day before she died she repeated frequently, and with evident delight, the words, "He knows the end from the beginning." She said that, much as she had admired the faith of the woman who touched the border of Christ's garment before, now it seemed more lorely than ever. several times she remarked, looking gratefully at Dr. Grant, "How good it is to have a physician that confides in God, and looks to him for success!" Once, when she said, "I am so unworthy!" it was remarked, "But unworthiness glorifies grace." -- "Yes, yes!" she eagerly replied; " $O$, what a blessed thought!" At her request, several passiges of scripture were quoted, and she repeated over again, with evident joy, "Yes, "Call upon me in the day of trouble. I will deliver thee, and thou shalt glorify me.' 'I go to prepare a place for you ; and if I go and prepare a place for you, I will come again and receive you unto myself, that where I am there ye may be also.', 'This last was one of many passages in her well-worn Bible that were marked, as having previously afforded her much enjoyment. Once, when in great distress, she exclaimed, twice over, " $O$, how much more mercy than I deserve!" As the night advancer, she lay in quiet unconscionsness, - her eyes fixed, her face and hands cold and clammy. The had despraired of any further recognition. Yet, once more, in answer to the inquiry, "Are you able to rest on Christ?" she anwered "Yes." But the "I am" that followed was rendered indi-tinct by the rattling in her throat; and, at a quarter before wre o'dock, on the morning of Deceniber 16, she entered into rest. She was buried the same day, in the court of the Jacobite church. Mar Shimon read select portions of seripture, and pronounced the benediction at the grave. Jacubite and Testorian priests stood side by side, mingling with 
tears for the dead, kind words of smpathy for the living. Her remains lie beside those of Mr. Hinsiale, awaiting the resurrection of the just.

In communicating this fresh berearent to the committee at home, Dr. Grant says: " Hers was at life that neeled no deathbed testimony; though this was not winting. Her work was done. A noble testimony of Christian devoteduess had been given in her consecration to one of the most difficult and trying fields in modern missions, and she neels not our poor culogy to embahm her memory."

Two days after her death, he wrote to Mrs. Jones, at Oroomiah : "You will sympathize with us in the los of dear Sister L., who left us in the full enjoyment of the Christian hope. We all feet her loss very deeply. It seems to each of us a personal bereavement. We were all one family, and all one in heart. May the Lord, in merey, sanctify to us this affliction! How frequent our admonitions to live wholly for Christ! A lively sense of the nearness of eternity would increase our firelity to the perishing, and impart tenderness to all our intercourse with those who mat soon perform the last sad offices to our lifeless remains, or we to theirs, - with those in whose society we hope to spend eternity, where the sin and suffering that annoy us here shall be known no more."

Sereral Jacobite priests came to sympathize with us, the Sabbath after the funeral; and, as it was near the regular hour for the Bible-class, they remained to attend it. But, for this they were shaiply rebuked, by one whose name need not be repeated.

About a month after the death of Mrs. L., ocenred another, of a different character. Mohammed Pasha, who had imbibed a love of strong drink with his other European tastes, was seized, on the 13th of January, with inflammation of the heart, and died, after an illness of only five days. His intemperate habits rendered recovery almost hopeless, from the first; and when the news of his death spread through the eity, it was the sigual for 
general rejoicing among the Most ms, - for his exactions har been more impartial than they had found agreeable. Men kissed each other in the streets; and so marked was the popular indignation that for a long time not even a stone was set up to mark his grave. The Christiuns also felt a momentary relief, yet rejoiced with trem? ing, lct his successor should increase, rather than diminish, their bukens. Dr. Grant was summoned to him as he lay on the divan of his ieception room, surrounded by the mercenaries of the palace, instead of his family, thongh they were under the sune roof. But, with his usual prudence, he gare no medicine, and only advireil with the Armenian physicim, lest he should be charged with bringing ahont the result he saw was inevitable.

A day or two after, Dr. Grant wrote to Mrs, Jones, at Oroomiah :

"Two weeks ago, I received a letter from niy eldest son, beg" ging me to return, 'for the salie of his younger brothers.' I do hope yet to be allowed to stay till I see a work of grace among the dear Nestorians. Whon will the work of the Lord be revived at your station? When will obstacles be removed out of our way? I :ee not what can be done to relieve the distracted state of the mountans. Our horizon looks darker and darker. In one direction alone is light. It is upwards! towards the eternal throne! There all is light and all is love. O, precious truth! 'The Lord roigneth, let the earth rejoice' Our plans may fail, but God's never! All the commotions that try our faith are wrying out his plans. Greater judgments may yet be poured upon these guilty lands; but they prepare the way of the Lord. The day of merey is at hand, when "Israel shatl bud and blosson, and fill the fice of the world with frut.' I an no prophet; but, if I have not been a dull scholar, both of prophecy and providence, we shall, within a few years, see yet greatei changes in these land, and all concentring in Crod's infuite plans of merey to a dying world." 
One camnot read any of his letters witten about this time, and not be struck with the pensive yet heavenly spirit breathed through them all. Weseen to eateh the notes of a plaintive but deep-toned music, firon the horders of another world; to stand in the presence of a great heart, and see ciol cut off, one by one, the stiong tics that homm it to carth, and fisten them on himsolf.

So it was with his attelenent to his children; so it was with his affection for his frient:; and so also with his love to the people for whose sake he had left them all. Wrery earthly bond of interest in that people seemed to fade away, and give place to others, exclusirely associated with God and hearen.

But, to return again to the Nestorians. Their independence was gone, beyond recovery. Nothing remainel to any of the tribes hat the most abject submison to their oppressors. Those who were not slain were ground to the rery dust. Fet some were too proud to confess this; and especially a few who had fled to Oroomiah, aware of our anxiety to labor in the mountains, and hoping; by our means, yet to humble the Kurds, hinted that our operations there had ocensioned their disasters, by way of enforcing a claim on us to return and undo the evil.

But to the refugees in Turkey their utter overthrow was too palpable to be deniel. Winter drew near, and thousands, houseless and destitute, left the snows of Tyary for the villages near Mosul. They were without money or fool, and almost without clothing. The widow was still weeping for her slaughtered husband, and the orihan comprehended his luss too elearly in that sore distress. In such extremity they fell into the hands of the Chaildans ; and forty thotisnd piastres of French gold were sabl to have ailled the arguments employed to conrince them of the itentity of that chach with ther own. Poor people! they had never been tanght the truth; and, hangry and bioken-hearted, what could their innorance proves to the craft of their wily benefactors? To counteract the insuce, Mr. 
Badger took a number of them into a house he happened to have unoccupied at the time. Dr. Grant hesitated to spend missionary funds in relieving mere temporal distress, when, to do anything adequate to the emergency, reciured so large an ontlay. But, one morning, fifty of his old acquaintunese, healded by ono of the priests of Ashithat, cntered the conit-yard and threw themselves oin his hospitality. Mis plans were formed at once. He hired a house, selected the orphans and widows with children, hesides some of the more helpless and infum, fed them, dothed them, and formed the children into a school. Not contents with this, he sought ercry apportunity to point them to is better Friend, who gave his life for their salvation, - - to a heavenly Father, who, with his own Son, was ready to give all other things. On subbath he regularly met with them, and, in his kind and familial way, mfolded the consolations of the word of God, and sought to lead them to the Saviour. Thus the winter was gliling away, when a low typhus fever broke out among the bapless fugitives. It attacked them in the villages; it found them out in Mosul; it raged among the Turkish soldiers in the barracks; and so fatal were its attacks, that out of the ninety Nestorians under the care of Dr. Grant, as many as twelve followed each other rapidly to the grave.

The Chaldeans now refused them burial in the cemeteries that had but lately belonged to Nestorian churches. Mr. Bidger made a vigorous attemp, to induce the pashat to compel them to this act of humanity. For, to do him justice, he spared no effort for their political good; and if Mar Shimon is not now the civil had of the Nestorians, and the dust of his followers reposing quitty in their ancestral grave-yards at Mosul, it is throngh no lack of labor on his part. But his efforts were in vaiu; and the sacobites kindly opened their church-yards to their theologica opponents. Hitherto, a few had been allowed to resile in courts of the Chaldean churches, as is the custom of beggars who subsist on the alme of those going in to worship 
(Acts 3: 2). But now the disease extended to them also; and whoever fell sick was forthwith driven out, lest the question of burial should conc up in a new form. One poor man, thus cast out, dragged himself to Dr. Grant, and, after receiving medicine, could only throw himself down among those already under his care. These were so crowded, in a small house it was inpossible to rentilate, that their recovery was very slow. But they had just begun to improve, when another victim of papal mercy was thrown down among them in the agonies of death, without a word suil to Dr. Grant. The poor wretch was beyond relief, and the presence of another corpse would only endanger the survirors. So he ordered the man who brought him to carry him back. Instead of that, he laid him down in a Mohammedan grave-yard, where he miserably perished.

Mr. Badger had a larger number of the Nestorians under his care than Dr. Grant; but, as soon as the diseuse appeared among them, he saved himself any further troublehy dismissing them all at once.

On the 29th of Yarch, we were cheered by the arrival of $D_{P}$. Smith. He had obtained the firman refused hefore the war, with only Julamerk left out of the list of places he was authorized to risit. He arrived not only in safery, but with his health actually improved by the journey; thus showing that the sad results of the journey of Messis. Hinsdale and Mitchell, over the same route, were entirely owing to the lateness of the season. He left Beirût in a Britich schooner, for Iscanderûn, Fobruary 24; commenced the land journey to Aleppo on the 29th, and arrived there March 4 . Setting out again on the 9th, with a new muleteer, he passed through Bir on the 11th, Orfah on the 13th, and on the 19th reached Diarbekr. Thence he went by post-horses, one day, to Marlin; and, starting from that place on Monday the 25th, he arrived at Mosul on Friday morning.

In a letter to the writer, dated October 13th, 1852, Dr. Lay- 
ard says: "As you are writing of Dr. Cirant, I trust you will not forget the mention of another man, early remored from his career of usefulness, but who has done as much as any man to promote the great work going on in the Last, and who was connected with several of your missions. I mean the late Dr. Smith, with whom I enjoyed friendy intercourse on several occasions." * It would be pleatrant to accele to this request, and speak of that good man more at length; but this volume has already exceeded its limits, and I can only say that the first impression he made deepened to the very last.

With characteristic precision, he had written fiom Mardin, to say when we might expect him; and, as Dl. Grant was indisposed, Mr. L. rork out to condret him into the city. It was a beautiful morning in sring, the air was exhilarating, and his errand ro less so. Anticipating the deight of welcoming another brother to the little band, so often bereaved, he rode rapidly along; and when he deseried him in the distance, could not resist the impulse to give the reins to his horse, and rush to meet him. But his eager welcome was met in such a sober, matter-of-fact way, as, for a moment, disconcerted him ; but only for a moment. They were soon as familiar as children of the same mother; and the stranger, intent on only one object, how he could do the greatest possible amount of good, - was at once a brother beloved. Such as he was then, so was he always. Never exeited, never depressed, - doing nothing in a hury, and never allowing a moment to pass unimproved. He pursued the chief end of man with a steadiness that rebuked the inconstancy of others, and an energy that was best understood by those who stood between him and that end. Ease or difficulty, obstacle or aid, seemed alike to that unwavering will.

* Compare "Babylon and Nineveh," p. 406, where Mr. Layard not only speaks of "the late excellent and enterprising Dr. Smith, and the estimable Dr. Grant," hut also makes honorable mention of other missionaries of the American Boarll in western Asia. 
And yet there was nothing harsh, nothing repulsive. If he ever appeared so, it was only to those who did not know him.

I see him now, conversing with a visitor. He has turned the conversation into a religious channel, and lays aride his spectacles as he listens patiently to some long onjection. Then, with a "Pek ae-ee. Umma banma bay" (" very good, but listen to me," - literally, "look at me"), he amihilates ihe ojection as quetly as thongh he only spoke about the weather ; or clears ul the difnenty so thesing that the in quirer is a thaned that he alled it such.

If he lat wot ail of Di. Crant's enthusism, he wais equally fearlesis in bing whaterer would promote the glory of God. And if not posicssed of the ready tact that made a good impression at the first, in the end it was not less favorable or abiding. Dr. Grant won you before you dreamed of being won; Dr. Smith quietly took your weapons out of your hand, as you raised them in self-defence, telling you there was no occasion for them; and in neither case did you ever regret that you were taken captive.

In another thing Dr. Smith differed from the subject of this memoir; and that was, in the prudent provision he made for his own wants. While Dr. Grant traversed the mountains with very little provision for his own necessities, Dr. Smith, when first met by his associate, was wapped in an Indiarubber cloak, that had sheltered him from the showers on the way. His legs were cased in felt, that answered the same purpose; ant a pair of holsters on his saddle, well filled with bread, seved alike for provender and protection. Still, we must not forgt that Dr. Grant was a pioneer in an unlnowi and dangerous region, and care about such things might have interfered with his success.

The work at Aintab owes no little of its unusual suceess to the labors of Dr. Smith. As an evidence of this, I will make a tingle extact from a letter dated Aintab, Oct. 8, 1850: 
"Yesterday our first property-tax, as a distinct people, was paid. It amounted to three thousind five hundred alid sixtyseren piastres; and the registry upon which it was made reports two hundred and eighty-six males in our Protestant community. The governor and council agreed that three hundred piastres of this might be paid perweek; and that sum was paid accordingly for eight weeks, when the pasha came with soldiers, and demanded of all sects their tax at once. The Protestant, therefore, paid their remaining dues; and, while all other sects are imprisoned by scores, not one of them is troubled. All this was'done without one para (tenth of a cent) of aid from us; though, in all the details of business, - levying the tax and securing its collection, - I ' go ahead,' and tell them what to do and how to do it.

"By the way, - excuse my suggesting it, - may you not be personally deficient in leading forward your people in this particular? organizing them into missionary societies, appointing collectors, talking with them of their duties, \&c. \&c. You know we are to organize, is well as lead on the hosts of God's elect. Not one-tenth of what we do would have been done, if I had not put my shoulder to the work of organization; and I suggest the thought, hoping that you will appreciate the spirit in which it is made."

If every minister would carry out this "suggestion" of our departed brother, the cause of Christ need never be straitened. Is this thing thought of as it should be? 


\section{CHAPTER XIX.}

PLAN TO RETURN TO ANERICA - LETTERS - SICKNESS AND I EATH - FUNER.L - TROUBLE'ABOUT TOMB-STONE - POSTHUMOU'S USEFULAES - LETTERS FRON MR. PERKINS AND DR. WRIGHT - ADDRESS OF NESTORIAN PUPILTESTIMONY OF MR. BADGER - LETTERS FROM HON. MR. LAYARD AND RET. D. W. MARSH - NOTICE OF MIISSION AFTER DEATH OF IR. GRANT DEATH OF CHILD OF MRS. HINSDALE - LETTFRS OF MICHA - SICCESSORS OF DR. GRANT AT MOSEL, AND IN TIE MOUNTAIS - FATE OF OPPOSERS - CONClusion.

While Dr. Grant mourned over the disasters of the Nestorians, he was yet further aflicted with news from home. His children again needed a father's care. Some of their guardians had died; and he thus writes, March 1, to his eldest son :

"My Tery Dens Box: When I received your fitror of September 9, I wrote to Dr. Anderson, then at Constantinople, who says, in reply, 'I think you had better go home and look after your children, after you shall have had the necessary conferences with Mr. L. and Dr. Siniti, at Mosul.' On reading this my heart was full, and I passed almost a sleepless night, though the opinion wals not unlooked for. The prospect, though distant, of seeing you and my other dear sons once more, affeeted me more deeply than I can express. I had long been weighed down with anxiety, particularly for your brothers, from whose guardi:ms I had received accounts awakening all the anxious feelings of a father's heart; while, on the other hand, the untold wants and woes of thousands ready to perish appealed to those tender chords that should ever vibrate in the Christian's heart. What should I do? An answer to this oft-repeated question had now eome. Strong as were the claims of the perishing, of widows 
and orphans around me, there are others who have a stronger claim on their father's care. The claim of my children has not been forgotten, nor can it ever be.

"It would be pleasant to look forward to a quiet home in America, with my children about me; but, though the thought that $I$ have none detracts from the pleasure of the prospect, it does not from my desire to return."

March 2:2, 184t, he wrote to the Rev. Mr. Girilley, then the guardian of his son Edwin, but who has since gone to his reward:

"You will doubtless have learned from Dr. Anderson that he has advised me to return to look after my children. "It is quite evident,' he says, 'that they all need their father's presence for a time.' You will not wonder at his advice, as I know it is also your own opinion. The thought of learing here is more trying than I had anticipated; for, even now, I have attentive assemblies, on the Sabbath, of from fifty to one hundred, and many opportunities for doing good during the week. But, perhaps I can be better spared now than at any other time; at least, I must go for a season."

The day a her, he wrote to his mother as follows:

"Mir Precrous Motuer: I write, not knowing where a letter may find you; but, wherever you are, to assure you of the warm affection with which you are ever regarded by your absent son, and the pleasure I feel in the thought of arain beholding the fuce of my mother. Yes, my dear mother, your son will soon return, if the Lord will, to cheer you in the decline of life. How long I may remain, should I live to see my dear native land, Providence must decide. But, if I can in any way comfort my dearest mother, it will go far to make amends for the pain of our long separation. May He who styles himself the widow's God watch over and bless you! My heart is too full, when I think of my lone mother, to allow me to say much of myself. 
But you will not be uninterested to know that, while my health is not at any time good, and while I feel the need of a respite from care, I am now in comparative comfort, and free from any great botily pain. I feol at times the weight of past trials, and the deep afflictions of my dear Nestorians. You have heard of their dreadful suffering, and rinyed, perhaps wept, over them. Poor, aflicted people! it fains me to think of leaving them. But my cwn children must receive a father's care, and be made to feel a fither's love. Sor is this altogether unexpected. When I consented to return so soon to these lands, it was with the expres understanding that my children would perhals render a mbsequent visit necesary. Should I, therefore, he permitted, in the divenarge of my paramount duty to them, to see you agin before we rass orer the Jordan of death, this will be a privilege I hare rather longed for than hoped to enjoy. But the prospect now is that I maly once more enjoy it, in the conise of the coming antum. Till then, my dear mother, farewell."

Little did he think that the meeting he so ardently desiren would be a meeting hefore the throne of God and the Lamb. Mrs. Ilinsdale, with her little boy, born Feb. 6, 1\&43, needed to return to America; and, after Dr. Smith had arrived, and we had consultel together about future operations, his plan was to return with her to his native land.

With these nospects befre him, he was watching over the sick, and preaching the gospel to all, - little dreaming that he was doing his law work for the people he loved as missionary hat seldom loved the strangers for whom he labored. Many of them confered that he ared for them more than they did for one another. Few sorrowed orer their own berearements more than he dir orer the mireries of a people who had conferred on him but one faror -- the opyortunity of doing them good.

The same dicease that had proved so fatal among them now seized npon him, and his constitution was too much enfeebled to 
resist its power. The malady from which he suffered so much at Oromiah had never wholly left him; and his hardships in the mountains, joined to his strong sympathy with the distresses of the Nestorians, had so aggravated the disease that scarce a week passed without its day of sickness. If it did, the attack was only more severe in prepertion to the delay. It such times, after his stomach had rejected all food, he could only lie lown and rest till exhausted nature gathered strength enough to carry him through another interval of comparative health. And so commeneed his last sickness, four or five days after the arrival of Dr. Smith, whom God seemed to have sent on purpose to minister to his dying servant. He who had been so often alone in the mountains was brought among friends, and provided with the kind nursing of Mrs. Hinsdale, and the excellent professional services of Dr. Smith, in his hour of necd. On Friday, April 5, he complained of heing unwell, and went to the bath; but without finding relief. Sick as he was, he wrote that day to his son Edwin, as follows:

"My Ever Dear Son: I am happy to hear that so many feel a lively interest in your welfire. But, while truly grateful for this, I cannot forget the stronger ties that bind us together. Nor could you, my son, doubt for a moment the warm love I ceel, dirl you know the yearnings of my heart towards you, and now greatly I long to see you. That strong desire I now hop will be gratified; and I trust the gratification will not be an transient as in my former visit. We then saw each other so little, that it was tantalizing rather than satisfactory. I was such a stranger that you hardly knew me; and then my visit was so huried that you must have felt, when we parted, that I was still almost a stranger.

"I am glad to hear that both you and Hastings are making such proficiency in your studies; but I feel most solicitous that you should both learn the one important lesson of love to God. 
"The wars that have laid waste the homes of the poor Nestorians are still starcely hushed. Even in the inclemency of their mountain-winter a village has been sacked and burned. About twenty were killerl, and many were taken prisoners. But, in the midst of all these commotions, we are safe under the protecting power of trod. 'His arm has been our shield through every danger, and we trust Him still and ever."

These are the last worls he wrote; and the letter, in some places, gives evidence, in its disjointer style and frequent cmissions, of the effort it cost to write it.

Sabbath morning he sat at the table with us for the last time; and on Monlay resorted to active measures to break up the fever that hat alrearly commenced. This he found impossible; and, three days after, resigned himelf entirely to the nerdical care of $\mathrm{Di}$. Smith. On the $11 \mathrm{th}$, the post brought additional letters from the gaardians of his children; and, perhaps owing to the excitement of this, next day he became worse; and so continued, growing rieaker, till, Saturday night, diarrhced set in, and reduced him still more. The following babath he seemed to hare a deep sense of our need of strong confidence in God in this time of trial, and, calling Dr. Smith to his bel-side, requested him to pray in behalf of the mission and the poor Nestorians. He then offered prayer himself, as he lay; - nothing uncommon in the blessings sought, nothing strange in expression, but uttered with such a holy ferror as gave new force to the most familiar words. He began, saying, "Lord, we are not worthy to ask anything" firm thee; but thou hast invited us to come," and closed with "All these things we ask in the name of the Lord Jesus Christ." Dr. Smith said, afterwark, "It seemed as thomgh I had never" known the depth of meaning containcd in these expressions before."

Surely that fervent, effectual prayer of the dying missionary was not unheard; and blessings may yet descend in answer to 
it, as dubtless they have descented atready, mon those fatherless children and that ancient church. As yet, no one apprehended danger; but Monday came, and reason had fled. Ile knew not that he was learing earthly friends till he foum himself, as we trust, among the redeemed ahore. He was kindly spared the knowledge of danger and death till they were all pasced, and passed forercr. Disconnected sentences, halfutterer thonghts, shut ont his associates from intercourse with their dying brother. True, a smile greeter their entrance into the room: bat strange thoughts brote in upon his words of welcome. The hand was stretched out, hut, ere it was graped in theirs, the mind had lost all recollection of the act. And yet there was no wildness oi excitement, but a quiet and kindly incoherence. A smile was ever on the face; and, if your question was unanswered, you had insteat the utterance of the hapyy thought that moment in his mind. At times he was studying the comfort of his widowed companion, on her loug jouncy to the coast; and once, mistaking the languor of clisease for the weariness of a day's travel, he asked how long he might remain and rest. "Just as long as you wish," replied his attendant, -.. for one, if not both of us, was genera'ly at his side. "No," said he; "I wish jut as the lord pleases,- no more. Ah ! these days! I don't know - don't know! - these days!"

His chillien were often in his thoughts. "My dear children! Gon will take care of them. God wrL take care of them, and the cause in which their father is embarked!" Then he would call them by name, and, as if his call was answered, invite us near, and embrace us, rejoicing in a reünion not to be realized on earth. Next to the cause of Christ they were uppermost in his thoughts. The last letter he ever wrote was to them. And one whose grave he now shares used to say that, during his frequent ilhesses, she could nerer comfort him so much as when she expressed an interest in them, and let the kind father speak of thoss he loved. 
Sumetimes 'se was pleading the cause of his Master bef re the chures at home. But oftener he was agin in the nountain, telling the Nestorians of a eompassionate Saviour and hearenly comforter. Or, addressing the desolate few in Mo:ul, daily thimned by death, and longing for the mountain home matry. were never to see again ; "fiee grace," "a Father's hand," and "mansions rrepared for those that love him," told of the thenes he had been accustomed to present before them.

When he thought himself alone in the closet, "Jesus, ny siviour, - my only Saviour! Yes, there is my Saviour! I hope, in infinite merey, through Christ, ny only Saviour," were the words that revealed the basis of his hope. Not death oft liraved Por Jesus' sake, no worthiness of his own, but a precions atonement, revealing infuite mercy for the lost, was his favorite theme.

And so he lay seventeen long days, the same smile on his wasting features, the same utter absence of complaint. He, who had loved to do good to all, knew not how all classes sympathized with him. And, when he died, though we looked anxiou ly for a moment of reason, none came; and we knew not whether that last sinile was still unmeaning, or told of the entrance into the joy of his Lord.

Thus he died, on Weanesday, April 24th. Death had often lifted his hand to strike, and as often had he pressed on caimly, "enduring as seeing Him who is invisible." God honored the con. filence of his servant; an now from a quiet resting-place lie took him to Mimself in a tinie of perce. He was not cut off in the mountains, lest any should think that God forsakes the soul thet trusts in his protection, or some future missionary le arait, when called, like him, to fear not them that kill the body. We may be comforted, also, that he did not die at home. For the grief of his aged mother and his children could not have 3 crm: such a testimony to the power of a holy life as did the tents the Turkish governor, and the multitude, who could restrian no ther their sobs nor their commendations round his grare sui 
devout men alone made great lamentation orer him. Some of the people rebuked us, berause, they said, while all Mosul was in tears, we alone did not weep. All ranks and religions watched the progress of his disease with affectionate anxicty. The French consul visited him daily; the Kaimakam, then acting governor of the eity, came also in person to inquire for him. On hearing of his death, Mar Shimon said, "My comtry ant my people are gone! Now my firiend is gone also, and nothing remains to me hut God!"

Let us thank Gorl that his borly lies in the fied of his lathors, to remint the peonle of his life, and the Mesced Saviour, who was the roune of all that made it lorely! Let no one repine becaure he was not allowed to give us his views of the nissionary work, as he ricwed it from the gate of heaven. Let ws rather thank God that, as he said of another, his life did not leave us dependent on the comfort of a death-bed testimony.

And yet he disl leave a testimony more than usually precious. We expect the dying believer will speak of Jesus, and of heaven. But when reason is dethroned, and piritual desires still shine out upon us from the departing spirit; when the wandering thoughts wanler to the cross; when the inquiry, "What do you want?" brings back the reply, "Pardon, through Christ. Thou, O Sariour, art my only hope;" what greater comfort can we ask? Such worls come unstudied. The soul did not mean to ntter them; but its deep emotions more the lips by their own intensity, and we listen to words not designed to make an impression, hut revealing the true character of the unconscions spirit. We may grieve that we were not recognized; but we rejoice that the pang of separation was unknown, and love to think of the heaven that broke suddenly on the ransomed spirit; opening its eyes on the glory round about the throne, and wondering how it entered that abode of bliss.

One fact in his protracted delirium deserves to be recorded. Though speaking almost constantly on many topics, in three dif- 
ferent languages, - that is, English, Turkish and Syriae, - he did not utter a single word he would have been ashamed of afterwards. His associates listened to those disclosures of his secret heart, and wondered that nothing appeared they woula have wished to conceal.

The day after his death, his funeral was attended by all the Franks in the city. The Jacobite priests and bishops, and the Nestorian Patriarch, with his priests, read portions of scripture at the church, and his bereaved associates offered prayer at the house and at the grave. The mountaineers mourned as for their dearest earthly friend. Some of the people wept aloud, is the proeession passed along the streets; and at the grave a large concourse assembled, to pay him their last tribute of respect. There, it night have been said, as truly as at the grave of the Scottish Reformer: "Here lies one who never feared the face of man." His body was laid in the same tomb with that of Rev. Mr. Hinsdale and Mrs. J. The place is marked by a tombstone, erected by him to the memory of Mr. Hinsdale, partly by the labor of his own hands. Those afterwards prepared for him and Mrs. L. were not allowed to be set up. The ieason assigned was apprehension lest their erection should gire the Americans some right of possession in the ehurch; but the real reason was probably very different.

I shall not attempt a fomal delineation of the character of Dr. Grant, as a man or a missionary. That is best learned from the preceding record of his life. Thus much I will say, he did not live in vain. His hand is withdrawn, but the inprlse it imparted still remains. Not one of his sufferings was endured for naught, and no danger braved for Jesus' sake but still glorifies his Saviour.

The Kurds will never forget the man who kept his word, and went about doing good to friend and foe; and when future mission wies seek to lead them also to Jesus, his memory wil? pre$\mathrm{lar}$ : the way before them, and lend force to each exposition of 
the glorious gospel of the blessed Goul. His kind feelings towards them were thus expressed, in a letter to Dr. Anderson, a few weeks before his death: "For the por benighted Kûrds, whom God has employed as his chastening rod, let our prayers arise, 'for they know not what they do.' Like persecuting Saul, they think, in their delusion, that they are doing God service."

The Nestorians will never forget him. For his sake they have welcomed other missionaries, notwithstanding the rage of their own Patriarch. His name will not soon perish from their traditions. The story of what Dr. Grant dared and endured in their mountain home shall nerve Nestorian missionaries, in future ages, to be faithful unto death. The sands and snows of Tartary did not intimidate their ancestors. From China to Abyssinia, and from Siberia to Malabar, they were in labors abundant. They roved with wandering tribes, and settled down in the cities. All Asia witnessed their zeal; all classes enjoyed the benefits of their labors. Dr. Grant, in this generation, stands like a beacon on their own mountains, to point them to these worthy deeds of other days, and remind them that they too may emulate their ancestors, in more firorable circumstances, and with more permanent success.

From his advanced position, also, he beckoned to Christians at home to look at the broad fields to be won, and the means provided, in the providence of God, for winning them to Christ. The eye of the church still follows his direction; and the longer she looks, the more she sees to rouse her to effort. Things invisible to him on earth slowly evolve from the mists of the future; and, ever as the horizon enlarges, it is more full of hope. Beyond the battles to be fought, victories and triumphs beckon us onward.

That these are not mere empty words, will appear from the testimony of other missionaries and also of men disconnected with the missionary work. Says Mr. Perkins, in a letter already quoted more than once: "Nultitudes here, to this day, repeat his name, with gratitude and veneration, from impressions 
received almost twenty years ago. His deep picty and earnest zeal for their salvation also made a strong impression on hundreds of the Nestorians; though he was not permitted to see them saringly affeeted, as many have been during the revivals enjoyed since his death.

"In the prosecution of the arduous and perilous mountain enterprise, the strong traits of his character were most strikingly develoned. Among the ferocious Kûrds, and the hardly less wild Nestorians, his great personal courage, his calmness amil thickening dangers, his unyielding perseverance in the face of difficulties, his distinguished skill in the healing art, and his remarkable tact in winning confidence and respect, had ample scope, and commanded miversal admiration.

"No less interesting, if less conspicuous. were his lively faith under discouragements, and his untiring efforts to make known the way of salvation, by word and deed, at all times and in all situations, till laid upon the bed of death. But I did not intend to dwell on his heroic labors in the mountains. I would only record the sincere satisfaction which I have felt on hearing his name repeated with affectionate reneration long after his death, as I stood over his grave at Mosul, wandered among the ruins of Ninereh, and threaded the deep gorges or scaled the snowy heights of Kurdistan, as well as on the plains of Persia $A$ precious harrest is yet to rise from his grave. His body moulders on the banks of the Tigris, but his memory is fragrant in all these regions. Many, both in time and eternity, will rise up and call him blessed. The hard mountain field, which drew so largely on his ardent sympathies, his bodily energies, and his fervent prayers, will, we believe, in due time, bud and blossom as the rose, and not a tear he shed over it, nor an effort he there put forth, will be lost or forgotten.

'That life is long which answers life's great end.'

"I often wonder why I, who entered the field before him, an still 
spared, unprofitable servant as I am; unless it be that I have so much more tardily and imperfeetly fulfilled my stewardship."

His successor in Oroomiah - Dr. Wright - says, "He was held in very high estimation by all classes. In Persia, I have heard the prince and peasant speak his praice; and in Kôrdistan the Kurd and Nestorian ahike dwell upon his excellence. In the castle of the emir, in the mansion of Mar shimon, and in the hovel of the poor 'Tyarian, I have noticed their veneration for his character. His memory is very precious to us here. I occupy his house; much of my furniture was his; here his sainted wife closed her earthly career, and the room in which I now write was his. I am constantly reminded of him, and I love to cherish his memory."

That this feeling was not confined to the missionaries is tonchingly evincel in the following extract of an address delivered by Sinum, one of the pupils of the Female Seminary at Oroomiah, at its anniversary, in 1852. She is the danghter of a momtaineer, and is now a valuable helper of Mrs. Coan in the mission station at Gawar. After some beautiful remarks on parting, she thus proceeds:

"And now, before we give the right-hand of separation for this year, it is good that we renew the wings of our loving thoughts, send them to the years that are past, and see where rests the dust of some of the dear teacher's of this school. Listen! there comes a voice: "They are not to be found among the living.' Yes, the place of one is empty here, and of another there. Then, where are they? An! thou, $O$ comntry, art a witness that they have pressed thy soil. Teblessed winds, l hear you answer, They have parted! Anl ye, green leaves of time, are true witnesses that they are to be found among the numbered dead. But where shall we find them? A wide distance is put between them. We must visit one * that first put her hand upon the 
head of some of us to bless us ; and though we remember her not, she many times embraced lis in the arms of love, and carried us before a throne of grace. Yes; she was one of the first that left all her friends behind, and ploughed the mighty waves of ocean, that she might come to Oroomiah's dark border. Though the fierce tempests and heavy waves raised themselves above the ship, her prayers, mingled with love for the Nestorians, ascended higher still, and overcame all. At the foot of Mount Ararat she doubtless remembered the bow of promise; and the consolations of her heart were renewed, when she thought of it as a prophecy, that a company of the fallen daughters of Chaldea should rise up and become heirs of glory. She so labored that the Lord is rewarding her, even to the third and fourth generation.

"But, though with such holy zeal she engaged in her work, her journey was short. Some of us had not seen our eighth summer when those lips, on which was written wisdom, were still, and that tongue, on which dwelt the law of kindness, was silent in death. Now she rests in this church-yard. She sleeps with our dead, and her dust is mingled with the dust of our fathers, till that day when she shall rise to glory, and a company of ransomed Nestorians with her.

"But where is that other dear friend of our school,* who was the beautiful staff of her support? Yes, he encouraged her to labor for us, while many of us were as yet unborn. His heart was large enough to love every son and daughter of our people. $\mathrm{He}$ sowed with many tears, and gave himself for the Nestorians. Shall we not believe that the fruits of his labors have sprung up among us? Then let us search, - where is he? Let us go silently, silently, and stand above that ancient city, Nineveh, and ask it, Where is he? It will direct us : ' Lo, he rests on the bank's of the noble Tigris.' Would that our whisper might reach the ear of the wild Arab and cruel 'Turk, that they walk gently by that stranger grave, and tread not on its dust! Then shall we 
think no more of it? No! with a firm hope, we expect that those mountains on which his beautiful feet rested shall answer nis name, in echoes, one to the other; and the persons who saw his faithful example there shall mingle in the floek of his Saviour.

"No, ye are not lost, ye spirits made holy; but, as it was necessary that some should come here to labor from a distant lind, so ye were necessary in heaven, to do a greater work. We believe that ye are doing more than ye could have done here. Yes, that ye are a part of that great company of witnesses that encompass us to-day. Then, loved ones, we would not call you thence; - cling closely, and more closely, to the bosom of your Saviour, till we too, through free grace, shall share in your glory!"

Mar Yohanna had written, in June, 1844: "When we heard of the death of Dr. Grant we felt very sorry, - not for his death, for he built his house upon the rock; it will not fill ; it will not move. But, alas! he left his work unfinishing."

On hearing of the death of Dr. Grant, Dr. Anderson wrote : "The mournful event awakens much feeling in the churches, and well it may. Let us pray that it may work for good to the cause so near the heart of our departed brother!"

But there is one testimony to the piety of Dr. Grant that must not be passed over in silence. Just before Mr. Badger left Mosul, he gave a beautiful copy of Bagster's Sabbath-school Treasury to Dr. Smith, who had attended on his dying mother; and in a note accompanying it wrote as follows: "I had left it out for Dr. Grant; but the Lord whom he served has seen fit to call him to Himself, where none of the least of his good works will remain unrequited."

The Hon. Mr. Layard, whose eonnection with Assyria is ton well known to need to be repeated, thus writes, Oct. 13, 1852: "I am glad to hear that you are preparing a memoir of Dr. Grant, whose memory, as a sineere and devoted Christian, a zealous and enterprising missionary, and a most amiable man, ought, by all 
means, ts be perpetuated among his countrymen. It would be difficult for me, at this distance of time, to note the actual expressions used, with reference to him, by those who knew him in the East. I have heard Hissuluans hear witness to his charitable and truly liberal dharater, which led him to extend the benefit of lis skill to all, whithont reference to sect, or prospect of reward; ant I have fresuently heard hin designated, both by Kûrds of the wild districts of the mountains, and by Mohammedans of Mosul, as ' the good doctor.' You know, fal' better than I do, his unrenitting attentions to the poor Nestorians during their misfortunes. It would be truly extraordinary if, notwithstanding the general absence of gratitude in the East, they were ungrateful to him. I have ahays heard him spoken of by the Christians of Tyary, as well as by those of Mosul, in the most affectionate terms. B!t, perhaps the best evidence that could be aldued of his high and amiable qualities is the general respect with which he was regarded by Europeans of all classes and religions opinions, during a time when, as you are well aware, there was, unfortunately, no very Christian or charitable feeling abroad. M. Botta, with whom I was all that time in constant correspondence, continually wrote of Dr. Grant as of a man who, by his liberal and truly Christian conduct, was an honor to the Redeener. Eren those gentlemen who were most opposed to his mission, and did their utmost to thwart his success, - using, it must be confessed, not very scrupulous means, - were glad to arail themselves of his aid and experience, and have borne a high testimony to his character."

The Rer. D. W. Marsh, of Mosul, writes as follows, October 7,1852 :

"Mr. Rassam, the English vice-consul, told me that he was often asked by Moslems, who knew Dr. Grant, When will another be sent to take his place? Indeed, I hardly ever saw Mr. R., during my first year in Mosul, without his making some allusion to his great lisefulness, the high estimation in which ho 
was held by all classes, and the great importance of a physician to take his place. It was owing to my representations on this point, together with those of Dr. Bacon, that Dr. Lobdell was sent to join Mr. Williams and myself at Mosul.

"Mrs. Rassam, who is widely known to all who have visited the ruins of Nineveh as a lady of remarkable energy and influence, and possessing an untsual familiarity with public business, has often expressed her high sense of the noble character and great usefulness of Dr. Grant.

"Persons in plaees as widely separated as Telkeif, Jezira and Mardin, have spoken to me in extravagant terms of Dr. Grant; and, after making all due allowance for oriental hyperbole, enough remains to show that a man who excites such rapturous praise so long after his death must have had a character fitted to make a deep impression.

"When a captive, with Dr. Baeon and his son, among the Kûds, we found chiefs who had heard of his reputation ; and one remembered him as the only Frank he had ever seen.

"Mrs. Schneider has told me that a wealthy Armenian, of Broosa, whose life was once saved by Dr. Grant's professional skill, to this very day loves all Americans for his sake.

"I have never seen Dr. Grant myself; and, were I to give impressions received from missionaries who loved him, it might seem a biased eulogy; but I have an impression derived ficit the living words and tones of native Christians, Moslems and Kûrds, high and low, - an impression virid and well defined, - that he was a most remarkable man. The inage thus formed, to a rommanding figure, and great nohleness of namier, alils ns fiank and manly a life, a policy at once so coarteous, open, ant yet firm, that men conceived for him at once an enthusiastic jegand. Fearless, even to an extreme; full of firith, even to enthusiasm; shrinking from no hardshipr; at hone in the Kuadisb castle, the Nestorian hut, or the palace of the pasha; everywhere a Christian and a Christian teacher. Whether with 
the Patriarel. or his servant, inculeating the same universallyadapted truth. A man in advance of the slow pace of the church, with a faith to attempt all things, whose bones will be wept over, and his memorial set up, when the great army comes to the spot where he fell."

I will not weary the realer with the detail of occurrences after his death; and yet one scene may not be left umnoticed. Mrs. Hinsdale, owing to the death of Dr. Grant, had not returned to America as she expected, and the delay proved the occasion of a fresh affliction. Her little boy, who bore his father's name, pined away for months under the pitiless heat of summer. He had centred in himself all the affection that else had been bestowed on both; but neither affection nor unremitted attention could arail to save him. I shall not soon forget the night he died. It was in the middle of July, when the thermometer, every day, was above one hundred, Fahlr., and at night not far below it. Dr. Smith and the writer slept on a roof, on one side of the court; and, separated by the wall that smrounded it, Mrs. Ininsdale, her Arab maid, and little Abel, ocenpied another. It was, as it always is there in summer, a clear, cloudless night. The stars looked down on us as we slept. At midnight we heard the girl shriek, and, conjecturing the reason, - for we had long expected it, though not much hatd been said, - Dr. Smith hurried over. He felt for his pulse, but there was none. He put his hand on his little heart, and, when it ceased to beat, he told the mother. She heard, and, replying "The Lord can take better care of him than I can," turned to her companion, and quieted the wild outburst of oriental grief. The little stranger, who had numbered only seventeen brief months in a world of sorrow, was laid by the side of his sister, not far from the grave of his father and the rest; and his mother kept on the even tenor of her way, as if her child had not died, but only been taken out of her arms into the bosom of the heavenly Shepherd. 
After his death, all went to Sheikh Adi, and went a few days among its pleasant groves and fountains. Then, between the latter part of August and the midale of September, Dr. Smith and Mr. L. made a tour through the mountains as far as Berchulla ; and, after that, as there was no prospect of being able soon to resume libors in that field, and the missionaries at Oroomiah would be ready to enter as soon as the door was likely to be opened, they reluctantly turned away from what had been indeed a scene of trial, but endeared by the most sacred associations. Eight missionarics had gone there, and, of that number, only three lived to return. The mission had met with many reverses; - probably fer, in so short a time, ever experienced so many. Its beginning was full of promise; and yet, in little more than three years, it was suspended: but not long. Gol did not lead his servants there to toil and die in vain. The leaven still continued to leaven the lump, after those who had cast it in had been called away. Nicha, especially, though left alone, continued faithful. His light shone brightly in his own city; and his letters to young men of his acquaintance, full of Christian instruction and consolation, found their way even to Aleppo and Beirut. He maintained, also, a correspondence with one of the missionaries; and, as some may like to know the spirit of the converts in Mosul, a few extracts from his letters are here submitted to the reader.

In his first letter he says: "I try to throw off all fear; and I think I know something of that sweet saying of the beloved John, 'There is no feur in love;' and I know that nothing can separate me from His love. Though some persecute me, it is enough if I only have grace to do His will. I would be ready even to die for Him who died for me. It $\mathrm{i}$ Christ alone I onght to please; and he who builds his house on that rock is secure against all storms and floods. I try to urge all to repent, without any fear of nan. Some confess that I speak the truth; but, alas! they produce no finit. bitt I have 
hope that the grain of wheat, if it fall into the ground and die, will not remain alone."

The writer can ahmost see him as, after one of our bereavements, in Mosul, he stole gently into the room, and, in his quiet way, half afraid to renew grief, and yet longing to comfort, repeated that same thought, intimating that, just as the seed must die in order to produce the increase, so the body just lairl in the grave would not only rise again, but rise with others, brought to the enjoyment of eternal life through its death. He adds: " Pray for me, that God would keep me from sloth [he is fechle, and suffers exceedingly from the heat of summer]; remove from me entirely the love of the world; and enable me, in my loneliness, to be perfect in his service; for I am all alone. I long to impart to others that which God has giren me, and that is, the revelation of his dear Son, sent down from hearen, crucified in my stead, that he might save me from the wrath to come. How shall I describe the greatness of my obligation to praise him for this grace? One thing I know, and that is, that everything is from God, eren faith also. Salvation is from the mercy of God in Christ. All is from him, and by him, to whom be glory and blessing forever !

"Dear brother, the work is great, and we have no power to turn a single soul to God. The sorrow and grief of my heart does not cease while I see so many souls without the knowledge of the Lord Jesus, and every day some of them dying without turning to Christ. What Christian ean see or hear of such a sight, and not weep? Pray for me, that I may have grace to instruct, and that they may believe!"

I. : a letter dated sept. 30,1849 , he gives the following aecount of himself:

"I was born in the year 1816. My parents were poor; and, with the neglect of spiritual things so universal here, they taught me nothing except the way in which I was to earn my hread. 
In 1828 the plague raged in Mosul, and swept away near forty thousand souls, my father among the rest; and I, too, was seized by the same disease. But the most High God, blessed be his name! saved me from death; for he had designs of mercy toward me, - even to give me salvation, through his Son Jesus Christ, in his own chosen time.

"When I was fourteen years of age $I$ felt that $I$ was a sinner, and would soon die, and go to hell, - just as 'Christian' felt, in the beginning of the book of Bunyan, - and I knew not what to do; for I had no one to tell me of salvation in Jesus Christ. When I sought for justifieation through good works and religious bbservances, my conscience found no rest. I was directed to confess to the priest, and, like the rest, I did so; but it profited me nothing.

"Two years after, I sought to learn to read; and the people ?aughed at me, and mocked me, - repeating the proverb

'Baad ma sar shab, yereed yitaalim el Ketab'

(After he has become a young man he would learn to read); for my people think that if a man does not begin to learn when he is five years old, he never can succeed. And when they saw that I did learn, they were greatly astonished.

" Then I became exceedingly zealous, like Saul of Tarsus, for my sect; thinking that we only were sure of salvation, and all else were in error. And I disputed warmly about things I had no knowledge of. I had heard, indeed, of the Bible; but never could obtain one, till, when God willed it, the missionaries came to Mosul, and brought it with them. Then I, and many others, read it; and as, in the light of God's word, I saw my guilt, I told you very often how I feared on account of my sins, and you comforted my heart; - telling me, "Christ has died in your stead, and what more is wanting after that?' Then I cast myself wholly on Him; and my heart rested; and I desired that everybody should come to Him. And now I have no sadness, only at 
the sight of sinners who will not come to Him, that they may be saved.

"At that time you said many things to me I could not very well understand; but, after you had gone, and I continued to study the Bible, praying that God, for Christ's sake, would explain to me the things that were difficult, thanks to his great name, He heard my request; and the gospel caused me to recollect and understand the things you used to say to me. Then, your letters were a great help, and the Arabic and English books I have. Yet all would have availed nothing, but for the grace which is in Christ Jesus our Lord. Nor am I now anything; but, in his merey, he risited me, and prepared me for the gift of faith in his dear Son ; - me, the sinner, unworthy to receive anything at his hand. Indeed, I think in myself that, though I should bring the whole world to obey him, yet that, too, would be the work of His power and merey, and not mine, that I should deserve anything on account of it. Of Him and to Him be glory for ever and ever. Amen."

It would be pleasant to make other extracts, did space permit; but these are enough to show the spirit in which he held fast the beginning of his confidence, far from all Christian sympathy, and a stranger among his own people because of his attachment to the truth. He supported himself by his old trade till the gift of a set of watch-maker's tools, from a benevolent lady in Boston, enabled him to set up that business; at which, I believe, he still continues, though in failing health. In one of his last letters, he writes: "I do not expect to live long; but, I trust, I have a sure hope in Christ, and that I shall go where I shall rest from sin and suffering. I shall see the Lamb, slain for me, and meet those with whom is the testimony of Jesus; and them, also, who loved me, and prayed for me in this world, where [ could not see them."

This young man formed the connecting-link between the 
mission to the mountain Nestorians and the present mission to Assyria. The report of his piety and labors led Messs. Perkins and Stocking to visit Mosul in May, 1849. The Rev. . . F. Ford, of Aleppo, wais sent there in November of the sante year, and remained laboring, anid much eneouragement, till April 10, 1850. Before leaving, he purchasel a howise for a Protestant place of worship; and in this, and the prelininary steps for the formation of a l'rotestant community, he enjoyed the counsels of Rev. D. W. Marsh, who had just airlved in this scene of his future labors. Long may he be spared to prosecute them, and see his bright hopes of the coming harvest eren more than realized! He has since been joined by hev. W. F. Willians, and Rev. H. Lobdell, M.D., with their fimilies, - the former in May, 1851, and the latter a year afterward. The seed sown in tears is now being reaped in joy. A little church was formed Nor. 8,1851 ; and, if the spirits of the departed are ullowed to look down on the scene of fomer toils, they that sowed rejoice together with them thit reap, and often fall down before the Lamb to praise Him, not only for grace all-sufficient on earth, but for each new eridence that not the smallest effort put forth in the service of Christ has been in vain.

While these cheering events occur around the grave of Dr. Grant, others, no less encouraging, transpire in the mountains. Repeatedly have they been traversed by his former associates. Those valleys, that echoed the shrieks of the slaughtered Nestorians, have again listened to the announcement of salvation through the blood of the Lumb. The feet of then that bring good tidings are again beautiful on those mountains. Being dead, Dr. Grant yet speaketh, and shall speak, through all those scenes of his lonely toil.

In August, 1851, a station was established in Gawar, not far. firm the place where he first met Mar Shimon; and the little boy who assisted in carrying his baggage to the canal-boat, in Utica, in 1835, now preaches the gospel there to the Nestorians. 
While God is thus showing that the labors of his servant aic had in remembrance before the throne, those who opposed then have been dealt with in a manner no less worthy of our notice.

Nûrûllah Bey, instead of enjoying his bloody conquest, fled from castle to castle, after leaving his stronghold at Julamerk in the hands of the Turks, till he was taken captive by the very power whom he aided to destroy the Nestorians; and now pines in hopeless captivity, far from the scenes of his former power.

Badir Whan Bey, after failing in one of his favorite nightattacks on the Turkish army sent against him, was taken prisoner in his own castle of Dergûleh, and now despairs of deliverance from his island prison in the Grecian Archipelago.

Suleiman Bey, who professed friendship for Dr. Grant only to prerent his strengthening the emir, after cruelly persecuting some Nestorian evangelists, was driven off to a like captivity; but died on the road, with his latest breath calling on one of his followers to sing a favorite melody of his native hills.

It only remains to be said that, of the three who left Mosul, Oct. 22, 184t, Dr. Smith has since entered into rest from amil the wonderful displays of grace at Aintab; Mrs. Hinsdale is still in the missionary field, at Constantinople; and the writer, unworthy of that privilege, here ends his sad yet joyful reniniscences of beloved ones now before the throne of God.

May the Master whom they served accept this contribution to the blessed cause in which they died! 


\section{N D E X .}

Agapæ, 136.

Aikin, Dr. S. C., 21, 22.

ing and Sabbath-keeping, 199. Cliure: $\epsilon$ s and priests, 260. Patriareh and fitness for missionary station, 261. Desclated by Zeiner Bey, 361 .

Ainsworth, Mr. William. - His intercourse with Mar Shimon, 151-153. His map and river Berdizawi, 257, 255. Rope bridges, 264.

Aintab, 69, 388 .

Akra, 125, 126.

Alarm in Ashitha, 320 .

Albakh, 235, 236.

Amadia, 127, 296-300.

America, visit to, 166, 169.

Anderson, R., D.D., 403.- Letters to. - Dr. Grant offers himself to the Board, 27,33 . His medical practice, 64 . His proposal to enter the mountains, 92 . Ilis faith in disc: uragement, 346. His proposition to labor in mountains after the massacre, 367-369. Animals in Kûrdistan, 295.

Antique bust, 186.

Arabs, 191, 199.

Arbela, 219.

Ark, place of, 340 .

Arzaleh, 137, 185, 254. Assassinate, 1lot to, Dr. Grant, 281.

Athanasius, Bishop, 201, 214, 217, 219, 281. Aurah:m, Kasha, 136, 315,

1 valanches, $2+5,2+7$.

Baasheka, 121.

Badger, G. P., Rev. - Ilis "hypothesis," 244. Erroneous assertion, 201. A pocrypha, 281. His own account of his course, 232-235. How regarded by his own church, 235. Labors with Micha, 370. Dr. Grant's course toward him, 251, 371-375. Mode of his opposition, 281, 286, 370, 382. Testinony concerning Dr. Grant, 403.

Badir Khan Bey, 105. - Sends spies to Ashitha, 314, 328. Dr. Grant goes to visit him, 322. His oppression of Christians, 329. Dr. Grant spends ten days with him on Yount Jûli, 333-340. IIs massacre of the Nestorians, $353-356$. His own fate, 112 . Ashitha.-Population, \&c., 137. Peace-mak-| Bash Kala, 148, 15!', 16:3. 
Bastawa, 292.

Beadle, Rev. E. R., 195, 196.

Bebozy, 295.

Bell, church, in Jelû, 182.

Berchulla, 2\%.

Berkho Malek, 347,348 .

Berwer Shawina, 162.

Beth Garmae, 124.

Bible-class in Mosul, 378, 379.

Birth-place of Dr. Grant, 1.

Botta, Mons. P. E. - Testimuny concerning Turkish oppression, 209-211. His amiability and kindiness, 290. Persecuted by the pasha, 375 .

Braintrim, 18-:0.

Bridge at Mosul, 119.

"6 mountain, 253,264 .

Building in Tyary, 316.

Burdasoor Castle, 82.

Captives, treatment of, 357 .

Caravan fort, 44.

Causes which led to the massacre, 104, 105, $372-376$.

Celibacy among Nestorians, 139.

Charreh, 228, 232 .

Chesney, Colonel, 127, 209, 264.

Childhood of Dr. Grant, 15, 16.

Children of Dr. Grant, letters to, 78-80, $154,157,390,393$.

Children, missionary, 166.

China, Nestorians in, 51.

Cholera, 73, 74.

Christian character of Dr. Grant, 24, 95.

Chumba, Malek of. - First visit of Dr. Grant to, 138, 139. Second visit, 254. Losses in 1842, 321. Slain by Badir Khan Bey, 351.

Circumcision, Kûrdish, 328 . 6 of Yezidees, 121.

Climate of Mosul, 201, 202.
Climate of mountains, 229, 307.

Comuissariat of Dr. Grant, 327,341 .

Conolly, Capt., 115.

Constantinople, usefulness in, 37, 39.

Conversion of Pr. Grant, 17.

Cooking, Nesturian, $245,254$.

" Kûroish, 326.

Courtesy between missionary societies 366 .

Crane, Rev. E. II., 35, 411 .

Crops in Tyary, 134.

Curiosity of Nesturians, 246 .

Dahar, pass of, 44,107 .

Daurhters of Dr. Gaunt, death of, 155, 156.

Decision to be a missionary, 2t-26.

Deed of real estate, Syriac, 265-267.

Deir Zefran, 113, 206.

Dergûleh, 333,338 .

Derrek, Mount, $1+7$.

Dervishes, 171.

Deshtaly, 301.

Dey, 325.

Diarbekr, 111, 197.

Diet of montaineers, 182.

Diss, slaughter in, 348,349 .

Doctrines of Nestorians, 55,56 .

Dress of Nestorians, 134.

" " "Badir Khan Bey, 339.

Duree, Bishop of, 130, 350.

Easter in Ashitha, 311-314.

Education of Dr. Grant, 14-17.

Eldership of Dr. Grant, 18, 22.

Embarkation of Dr. Grant, 35.

Emir of Ilakkary. - Position, 104. First interview with Dr. Grant, 148. Alliance with Turkey, 164, 373. Alliance with Persia, 228. Expedition against Amadia, 238,240 . Life in camp, 243, 244. Jealousy of, 2:3, 262. Expelition fails, 263. 
In Bahtan with Badir Khan Bey, 333-336.

His agency in the massaere, 104, 105, 228, $335,336,372,373$. Ilis fate, 411 .

Entrance into 'Tyary, 131, 192.

Erbil, 219.

Eัzrùm, 108.

Wvening meetings in Oronmiah, s5.

Exactions in Mosul, 209.

Famine, 172.

Fasts, 189 .

Fearlessness of Dr. Frrant, 16, 93, 118, 17s, $192,249,271,368$.

Feast in Ashitha, 311-314.

Female readers among Nestrians, 189, 231. " seminary at Oroomial, $, \$ 4,140,401$.

" missionaries, 30,31 .

Fiereeness of Nestorians, 159, 317, 318, 324.

Firmans refused, 319, 335.

Ford, Rev. J. E., 411 .

Fountains in Ashitha, 261.

Fruits in Jelû, 182.

" " Kûidistan, 295.

Funeral of Dr. Grant, 398.

Furniture of Nestorians, 133.

Gawar, 411.

Geli Mazukah, 300.

Geography, Nestorian, 145.

" of mountains, $127,257$.

Georginn among the Kûrils, 338.

Grant, Mrs. E. L., 17-19.

" " J. S., education, 32, 33 .

" " " " labors in Oroomiah, 8t-86.

" " " death of, 97-101.

Greene, Rev. D., 371.

Gridley, Rev. W., letters to, $173, \mathbf{1 7 4}, \mathbf{1 7 9}$, 391.

Gugerehine Kala, 82.

Gûndûktha, 24 .

Health of Dr. Grant. - In Oroomiah, 94, 96.
At Mardin, 112. At Constantinople, in 1841, 168. In mountains, $271,277,319,337$, 346. In Mosul, 286.

Heat of Mosu1, 201, 202 .

Heiyo, 249,250 .

IFroine of Bastawa, 292.

Ilertush Ku ûrds, 162, 259, 260.

Hierarehy, Nestorian, 147 .

Hinsdale, Rev. A. K. -- Embarkation, $16 \%$. Trials on journey to Nosul, 195-200. Tour among villages, 214. Situation in Mosul, 215. Visit to Ashitha, 268. Sickness and death, 279-2s1.

Hinstale, Ars. S. C., 392.

" " " death of her son, 406.

Homes, Rev. H. A. - Appointed to go with Dr. Grant to Hesopotamia, 102. Detained at Constantinople, 108. Arrives at Diarbekr, 111. P'erils at Mârdin, 113. Returı to Constantinople, 114.

Ilouse in Oroomiah, 45.

" " Ashitha, 264-267, 306-308, 360.

Houses in Tyary, 133, 311.

" of rieh in Mosul, 293.

Interview with the emir, Dec. 1842, 274.

Intolerance, Moslem, 331, 332, 336.

“ papal, 385, 386.

Invasion, seeond, 360-362.

Ira Grant, letters to, $81,171,286$.

Ismael Pisha, 216, 276, 334, 336.

Jacobites, 203-205.

Jealousy of Nestorians, 182, 188, 262.

" " emir, 238, 262.

Jeln̂, mountains of, 180, 181,

Jews, 205, 212, 298-300, 328.

Jezira, 330, 331.

Jones, Rev. W., letters to, 168 .

“ Mrs., letters to, 318,383 
Iúli, Mou st, 332, 340.

.Tulamerk, 160, 273-277.

Kala el Llawa, 273.

" Kîmry, 325.

“ 'l Scringa, 146.

Kandi kileeseh, 236.

Kishat Mendo, I2s, 28.3.

“ Aurah:m, 136, 315.

Keli shin, 225.

Kesta, 32 t.

khan, 42.

“ Vialımût, 335.

Whorsibal, 210, 259.

Khosrova, :2:0.

Kindness in Kurrlistan, 161, I62.

Kuehannes, 23.

Kn̂rds, 103.

“ eneounter with, 175.

Kürdish repast, 243.

Labors in Oroomiah, 75.

Laurie, Mrs. M. F., 379-352.

Liayarl, Ilon. A. II. - His route of Xenophon, 333. Description of the death of the Malek of Chumba, 351. Deseription of scene of slaugliter at Lezan, 361. Commendation of Dr. Smith, 387. Letter coneerning Dr. Grant, 403, 404.

Leaky roofs, 316.

Leaving mountains, 350, 351.

Letter to New York Observer, 372-376.

Leviathan, 145.

Lezan, 136, 157, 304.

Lobdell, Rev. II., 6s, 411 .

Lorl's Supper among Nestorians, 135.

Lost Tribes, 58, 167.

DIaklûb Mount, 122-124, 291.

Malisgird, 174.

Malik Kassim Mirza, $7 \notin, 101$.

Manners of Nestorians, 260.
Manners, clerical among Nestorians, 263.

Iardin, sickness in, 112.

" sedition in, 113.

Mar Mattai, 122-124.

"Sawa, 35t, 355.

Mar Shimon. - First interview with Dr Grant, 145, 146. His lodgings at Ashitha, 305,306 . Jealousies between him and his people, 344. Testimony to the benefits derived from the influence of Dr. Grant with Badir Khan Bey, 356. Flight to Mosul, 356. Residence there, $376,37 \%$. Attents funeral of Mrs. L., 381, and of Dr. Grant, 398.

Mar Yoosuf, 281, 240, 24t, 263, 270.

Mar Yohanna, 63, 25.5, 403.

Marsh, Rev. D. W. - Deseription of seenery in Kûrdistan, 222. Letter coneerning 1s. Grant, 404-406. In Hosul, $\$ 11$.

Massacre at Diss, 345-3\$9.

" " Cliumba, 351, 352.

" " Serspidho, 354, 355 .

" " Ashitha and Lezan, 361, 362.

" "Tehoma, 364.

Hedical praetice, 61-66, 148, 185, 339.

Melek Taûs, 218.

Merrick, Rev. J. L., 57.

" " " letters to, $63,99,100,118$.

Mieha el Nakkar. - Early life of, 204. Is connected with the nission, 214, 215. Religious history, 369, 409, 410. Put to the test by Ir. Balger, 370 . Letters of, $407-410$. Nill in Tyary, 258.

Mineral springs, 236 .

Missionaries, how made, 32.

Mlissions, Nestorian, 18-53.

Nitchell, Rev. C. C., embarkation of, $16 \boldsymbol{i}$. Sickness and death, 195-198.

Nitchell, Mrs., sickness and death of, 199200. 
Mob, Nestorian, 315.

Honopolies in Mosul, 208, 209.

Mlosul, 201, 202, 206-213.

Mother of Dr. Grant, 1t, 15, 19. - Letters to, $28,73,76,156,391$.

Yountains, reasons for mission in, 83 .

Mountaineers, chiracter of, 139.

Mud houses, 289.

Murder, Kûrdish, 237.

Nazee, 140.

Nestorians, origin of chureh, 47 .

"6 religious character of, $56,60,61$.

Night ja mey in Berwer, 193.

Night anong the mountains, 241.

Nineveh, 119.

Nomad K ilds, 2:26, 234 .

Oprression, $207-211$.

" in mountiaiss, 359.

Ornaments of women, 276.

Oroomiah. - Scenery of, 59, 60. Magi in, 60 .

As missionary station, 61. Arrival at, 62,

63. Visit to, 227-229. Lakle of, 229 .

Papists in Ashitla, 269.

Pasha, Mohammed, of Mosul. - Desirc to subdue the Nestorians, 105. Vigor of his arministration, 114, 116, 206, 207. Farly history, 206. His rapacity, 205-209. His severity, 212. Plots the assassination of Dr. Grant, 281. His intrigues with the Nestorians, 321, 358. His death, 352. His successors, 209-211.

Patriarchate, Nestori:tn, 49, 54, 55 .

l'atriarch, relations to Kûrds, 101, 105.

beace-making, 189, 243.

Perkins, J., D.D. - Letter from, 72, 399, 400.

Letters to, 39, 117.

Physicians, missionary, 67-73.

Pillar nea'Sidek, 225.
Plague at Mosul, 21', 213.

Polities of Kûrdistan, 104

" "Nestorians, 255, 258.

Polygamy, 275, 234.

Population of nountains, 364.

Puverty, 297, 299.

"6 of Nestorians, 355.

Precautions in travelling, 148.

Proposition of Dr. Grant, 367.

Providence, missionary, 201, 377.

Rakam, 101.

Ravandûz, 221, 224.

" Bey of, 221, 222.

Reading, habits of, 15 .

Reception in mountuits, 133.

Refugees, Nestorian, $38 t-386$.

Reminiscenee, 170 .

Responsibility, 81 .

Riach, Dr., 4t, 107, 16.5 .

6 "6 Ietter of, 91, 92.

Rieh, C. J., Escl., 103.

Rouds, 42.

" mountain, 144, 145, 243 .

Robbers, lìntish, 276.

Routine, daily of Kûrdish chief, 339.

Rum, New Englind, 44 .

Sabbath in Tyary, 136.

Saladin, $10: 3$.

Salmas, $119,15 \%$.

Sinum, adilress of, 401-403.

Siljnah, 296.

S.his ls, Nestorian, ancient, 56 .

Scenery along the \%ah, $143,272$.

Schultz, 93, 16i.

Serspillu, $354,355$.

Slaklt, 341.

Shaw, Rev. J. B., 21, 102.

Sheer, milk of, 184 . 
Sheikh, Ali, 292.

Sheil, Col., 90, 91, 165.

" " his aceount of Jezira, 331.

Sickness, last, of Dr. Grant, 392-397.

sidek, 224 .

Sister, letters to, $29,76,77$.

Smitl, Rev. A.- His narrow escape, 247.

llis impressions of the mountains, 855 .

Statistics of Nestorians, 364, 365. Journey

to Mosul, 386. Character, 387. Compar-

ison between him and Dr. Grant, 398

Usefulness in Aintab, 68, 389.

Soeial life in the mountains, 317,330 .

Sons, letters to, 78-80, 154, 157, 390, 393.

Spies, Kûrlish, 314.

Stocking, Rev. W. R., 227 . - Letters to, 95 . 159, 164, 179, 215, 278.

Suleinan Bey, 104, 160, 161.

" " his death, 411.

Sunday-school, Dr. Grant in, 22, 75.

Sunless winter, $2 \pi 2$.

Superstition of Nestorians, 18.3.

Synagogues of Amadia, 299.

Tall, district of, 239, 240.

Tamerlane, 5t, 102 .

Turtars, 52, 53.

Tehoma, 185, 364, 365.

Telegraph, mountain, 242.

Temperance anong kurds, 238 .

Temple, Rev. D., 36.

Tent, Kûrdish, 16z.

'Twwanish, s01.

Theodore of Mopsuestii, 262.

Tigris, the, 115, 116, 288 .

Tortures of Nestorians, 362,363 .
;Travelling in mountains, $239,248,253,262$, 305.

Travelling in the East, 173.

Treachery of guides, 178, 192.

Trebizond, 41.

Usefulness, posthumous, of Dr. Grant, 398, 399.

Cshnei, 226.

I tica, life in, 20-2?.

Van, town and lake, $164,176,177$.

Wages in Tyary, 269, 270.

Waly Khan, 230.

Weather in Aslitha, 307.

Williams, Rev. W. F., 411.

Wine in the mountains, 186.

Winter without sun, 272 .

Woman as a missionary, $30,31$.

Women in Tyary, 134. - Able to read, 139,

231. Kûrdish, 275. In Mlosul, 294.

Wright, Dr. A. II., 165. - Letter from, 227,

401. Letters to, $165,190,213$.

Xenophon, 102, 107, 332.

Yahya Khan, 91, 101, 106, 225, 232.

Yezidees, 119, 120.

Zab, or Ziwa, 127, 12s.

" Scenery of, 14:3, 2\%2.

Zacho, 32't.

Zarny, 262, 301.

Zeiner Bey, 277, 325. - In Ashitha, 360, 362.

Zozan, 137, 243, 255. 


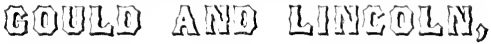

59 WASII N G TON STREET, BOSTON,

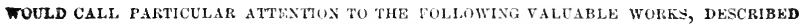
IN THEIR CATALOGLE OF PUBLICATIONS, VIz.:

THE ANNUAL OF SCIENTIFIC DIsCOVERY.

HUGII MILLER'S WORJS.

CHAMBERS' WORKS. HAKRIS' WORKS. NEWCOMB'S WORKS.

WAYLAND'S WORKS. AGASSIZ'S WORKS. GUYOT'S WORK3.

SHITH'S NATURAL HISTORY OF TIE SPECIES.

ANCIENT LITERITURE AND IRT, BY EDWARDS, SEARS, AND FELTON.

ARYINE'S CYCLOP.EDIA OF ANECDOTES.

BANV́ARD'S AMERICAN HISTORIES.

RITTO'S UYCLOPEDIA OF BIBLICAL LITERATURE. KITTO'S PALESTINE.

VALUABLE WORKS ON MISSIONS.

THE PSALMIST: A COFLECTON OF II MNS.

ELEGANT MINIATURE VOLUMES.

WILLIAMS' RELIGIOUS PROGRESS, AND LORD'S PRAYER.

CRUDEN'S CONDENSED CONCORDANCE.

RIPLEY'A SACRED RHETORIC, - NOTES ON GOSPELS AND ACTS.

VALUABLE SCIIOOL BOOJS. WORKS FOR SABBATH SCHOOLS.

WORKS ON CIIRISTIAN PAPTISM.

MAGOON'S REPUBLICAN CHRISTINITY, AND PLOYERBS FOR THE PEOHLE.

CROWELL'S CHURCII MEMBER'S MANUAL, AND HAND-BOOK.

JAMES' CILRCII MEMBER'S GUIDE, AXD CIIURCII IN EARNEST.

LIFE AND CORRESIONDFNGE OF .TOHN FOSTER.

WORKS IN

THE VARIOUS DEPARTAENTS OF LITERITURE, SCIENCE AND ARTG

REIIGIOUS WORKS.

VAIUABLE MISCELTANEOUS WORKS 


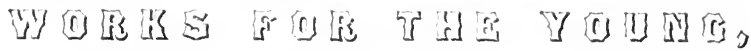 \\ PIBHISII E D B Y
}

GOULD \& LINCOLN, . IOSTON.

\section{PLYMOUTH AND TIE PILGRIMS ;}

9r, Ineidents of Adventure in the 1listury of the First Settlers, heing the first vulume of a series of American Histuries. By JosepH BAxvaRD. With Illus rations. $16 \mathrm{mo}$, cloth. Price $62 \mathrm{t}$ cents.

\section{NOVELTIES OF THE NEW WORLD;}

An account of the Adventures and Discoveries of the First Explorers of North Americi, being the second volume of Bdrvard's SERies of AMERICAN Histories. 16mo, cluth. Price 62 cents.

Other volumes of the series are in course of preparation. They will embrace the most interesting and important events which have oceurred in the United Stat ss since the first settlement of the country ; exhibiting, also, the trials and adrentures of the early colonists, their peculiarities of character aucl manners, their intercourse ani conflicts with the natives, the pardual development of their institutions, sketches of their prominent men in both the chmeh and the state, incidents in the Revoluion, etc. It is intended to be a NATIONAL SERIES $0 F$ AHERICAN HINTORY, adapted to the poyular mind, and es] cially to the youth of our country, illustrited with liumerons fine engravings; tach volume to be complete in itself; yet they will cogether form a regular consecutive series of twelve or more 16 mo volumes, of abont 300 pages each.

\section{YOUNG AMERICANS ABROAD;}

Or, Vacation in Europe; embodying the results of a tour through Great Britain, France, II olland, Belgium, Germany and Switzerland. With elegant Hllus rations. 16 mo, eloth.

THE ISLAND HOME.

With fllustrations. $16 \mathrm{mo}$, cloth. Price 75 cents.

THE GUIDING STAR;

Or, The Bible forl's Messare. Desinned to illustrate the second and third questions of the Westminster Catechism. By Locisa Parson Hopkixs. 1Smo.

05 An exceedingly interesting and instructive work for youth, on the eviciences of Christianity.

\section{IIOW TO BE A LADY.}

A Book for Girls, containing useful Hints on the Formation of Character. By Rev. $\mathbf{H}$. Newemb. Tenth thatinul. Cloth, gilt. Price 50 cents.

$$
\text { II O W TO BE A M A N . }
$$

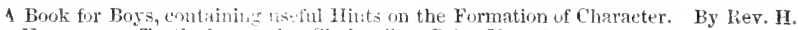
Newcosib. Tenth thouraml. CInth, cilt. Price 50 cents.

\section{ANECDOTES FOR THE FAMILY AND SOCIAL CIRCLE.}

$18 m o$, cloth. 63 cents.

\author{
LEARXIXG TO ACT-FEEL - THINK. \\ 15 mo, cloth, gilt. Fach 38 cents.
}

\section{ANECDOTES FOR BOYS.}

Entertaining Anecdotes and Narratives, illustrative of Principles and Character. By Rev. Harvey Newcomb. Sixth thousand. 19 mo, cloth, gilt, 42 cents.

\section{A NECDOTES FOR GIRLS.}

Entertaining Ancellotes and Narratives, illustrative of Principles and Charac $\mathrm{r}$. By Rev. 1Hariey Newcomb. Sixth thousand. $18 \mathrm{mo}$, cloth, gilt. 42 cents. 


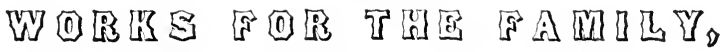

PUBLISHED BY

GOULD \& LINCOLN, . BOSTON.

\section{CHAMBER' CYClOPADIA OF ENGLISH LITERATURE.}

A Selection of the choicest productions of Eurglish authors, from the earliest to the present time. Connected by a Critical and Biographical IIistory. 'Two imperial oetavo volumes; with upwards of 300 elegant Illustrations. Edited by RoBekr Санамекs. Eubossed cloth. \$5.00.

Chambers' miscellany of USEFul and entertaining KNOWLEDGE.

Edited by Wirliam Chambers. With elegant Illustrative Engravings. 10 vols, cloth. $\$ 7,50$.

\section{KITTO'S POPULAR CYClOPADIA OF BIBLICAL LITERATURE.}

Condensed from the liurger work. By Jous Litro, 1). P., anthor of "The Pictorial Bible." With numerous Illustrations. Octavo, \$12 pl., cloth. \$3.00.

\section{CyClop}

Containing a copious and choice selection of Antedotes of the various forms of Literature, of the Arts, of Architeeture, Engravings, Insic, Poetry, Painting, Stulpture, and of the most cele!ritted Literary Charaters and Artists of different conntries and ages, ete. By KazitTt ARvine, A. M. With numerous Illustrations. Uetavo, cloth, 3.00. Also published in eight numbers, at 25 cents each.

\section{FIRST IMPRESSIONS OF ENGLAND AND ITS PEOPLE.}

By Hicg Mrilfis, author of "Old Red Sandstone," "Footprints of the Creator," etc., with a Likeness of the Author. 12mo, elotll. $\$ 1.00$.

\section{A WREATI AROUND THE CROSS ;}

Or, Seripture Truth Illustrated. By Rev. A. Morton Brown. With an Introdoction, by Rer. Junn Artiell James. With an elegant Frontispiece. 16mo, eloth. 60 cents.

\section{RELIGIOUS PROGRESS.}

Discourses on the Development of the Christian Character. By REv. William R. Williams, D. D. Second Edition. 12mo, cloth. 85 cents.

\section{LECTURES ON THE LORD'S PRAYER.}

By WM. R. Wilidaus, D. D., author of "Religious Progress." 12mo, cloth. 85 cents.

\section{TIIE CHRISTIN'S DAILY TREASURY.}

A Religious Exercise for every day in the year. By E. Temple. 12mo, cloth. $\$ 1.00$

THE EXCELLENT WOMAN,

As described in the Book of Proverbs. With splendid Illustrations, and an Introduction by WM. B. Spragee, D. D. An elegant Gift Book. 12mo, cluth, extra. $\$ 1.50$.

\section{MOTHERS OF THE WISE AND GOOD.}

By JABEz BCrns, D. D., author of "Pulpit Cyclopædia," etc. Cloth. 75 cents.

\section{THE IMITATION OF CHRIST.}

By Thovas ì Kemprs. Introductory Essay by T. Chalmers, D. D. New and Imgroved Edition. Edited by H. MaLCos, D. D. 13mo, cloth. 38 cents.

\section{THE MARRIAGE RING ;}

Or, How to make Ilome IIappy. From the writingrs of JoHN Axgell JA גes. Beauthfully Illustrated Edition. $16 \mathrm{mo}$, cluth, gilt. 75 cents. 


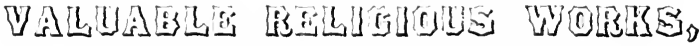

PUBLISIIED BY

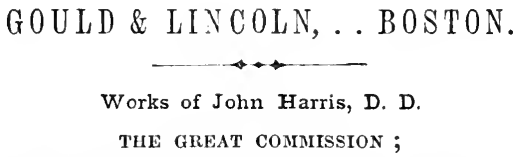

Or, the Caristian Church charged to convey the Gospel to the World. Introde etion by

Wr. R. Wilithits, D. D. $12 \mathrm{mo}$, cloth. 1.00 .

THE GREAT TEACHER;

Characteristics of our Lord's Ministry. Introduction by Dr. Husperey. 12mo. $85 \mathrm{c}$.

THE PRE-ADAMITE EARTH ;

A Contribution to Theological Science. 12mo, cloth. 1.00 .

\section{MAN PRIMEVAL;}

His Constitution and Primitive Condition. With Portrait of the Author. 12mo. 1.25.

$$
\text { MA H H ON-ZERULON-MISCELLA NIES. }
$$

Works for Church Members.

\section{PIILOSOPHY OF THE PLAN OF SALVATION ;}

A Book for the Times. Introduction by C. E. Stowe, D. D. $12 \mathrm{mo}$, cloth. $62 \frac{1}{\mathrm{c}}$.

THE PERSON AND WORK OF CURIST.

By Dr. Sartorius. From the German. By Rev. 0. S. Straras. 18mo, cloth. $42 \mathrm{c}$. COLEMAN'S PRIMITIVE CHURCH.

A postolical and Primitive Church. Introduction by Dr. NeAxper. 12mo, cloth. 1.25.

THE CHURCH IN EARNEST.

By Rev. Johx Axgell James. 18mo, cloth. 50 cents.

THE CHURCH MEMBER'S MANUAL.

By Rev. W. Crowell. Introduction by H. J. Ripley, D. D. 12mo, eloth. $90 \mathrm{c}$.

THE CHURCI MEMBER'S IIAND-BOOK.

By Rev. Williail Crowell. 18mo, cloth. 38 cents.

THE CHURCH MEMBER'S GUIDE.

By Rev. John A. James. Introduction by Rev. H. Wisslow. Cloth. 38 cents. REPUBLICAN CHRISTIANITY ;

In the Life, Precepts and Early Disciples of Christ. Ly L. L. MAGoox. 12mo. 1.25.

PROVERBS FOR THE PEOPLE;

Or, Illustrations of Godliness. By Rev. Elias L. Migoon. 12mo, eloth. $90 \mathrm{c}$. WAYLAND'S SERMONS;

Delivered in the Chapel of Brown University. By F. WAYLAND. 12mo, clotr. 1.00 .

TIE LIFE AND CORRESPONDENCE OF JOHN FOSTER.

Edited by J. E. Rruavo. Two volumes in one, 700 pages. 120 o, cloth. 1.25 . 


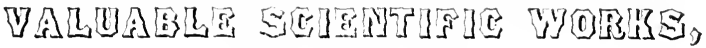

PU ILISIIEl) BY

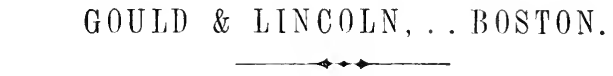

ANNUAL OF SCIENTIFIC DISCOVERY, (FOR 1850 AND FOR 1851;)

Or, Year-Book of Facts in Science and Art. Published annually; each volume containing entirely new matter. Elited by DAYID A. Whils and George Busss, Jr. With Portraits of Prof. Agassiz and Prof. Silliman. 12mo, cloth.

\section{THE FOOT-PRINTS OF TIIE CREATOR ;}

Or, the Asterolepis of Stromness, with numerous Illustrations. By IIUfH MuLLER, author of "The Old Red Sandstone," \&c. An elegant likeness of the author. With a Memoir of the author, by Lous Agassiz. 12mo, cloth. $\$ 1.00$.

\section{THE OLD RED SANDSTONE ;}

Or, New Walks in an Old Field. By Hegh Mulfer. Mlustrated with Plates and Geological Sections. $12 \mathrm{mo}$, cloth. $\$ 1.00$.

\section{THE POETRY OF SCIENCE;}

Or, the Physieal Phenomena of Nature. By RoBeri IIUNT, author of "Pauthea," "Researches of Light," \&c. 12mo, cloth. \$1.25.

\section{TIIE NATURAL HISTORY OF THE HUMAN SPECIES ;}

Its Typical Forms and Primeval Distribution. With elegant Illnstrations. By Chas. Hamilos surt. With an INTrodectios, containing an alstract of the views of the most distinguished witers on the subject. By Samuel KNELlayd, Jr., M. $\mathbf{D}$. $12 \mathrm{mo}$, cloth. $\$ 1.25$.

\section{LAKE SUPERIOR;}

Its Physical Character, Vegetation, and Animals. By L. AGassiz, and other eminent Scientilic Gentlemen. With a Narrative of the Expedition. By J. E. Cabot. Elegantly illustrated. svo, cloth. $\$ 3.00$.

\section{PRINCI PLES OF ZOOLOGY,}

Touching the Structure, Development, Distribution, and Natural Arrangement of the Races of Animals. With Illustrations. For Schools and College's. Part I., CoM parative Physlology. By Louis Agassiz and Acgestes A. Gould. Third thou sand. 1:mo, cloth. $\$ 1.00$.

\section{THE EARTH AND MAN;}

$\mathrm{Or}$, Comparative Physical Geography in its relation to the History of Mankind By ArNOLD GUYoT. With Illustrations. $12 \mathrm{mo}$, cloth. $\$ 1.25$.

\section{COMPARATIVE PHYSICAL AND HISTORICAL GEOGRAPHY ;}

Or, the Study of the Earth and its Inhabitants. A series of graduated courses for the use of Schools. By ARxold GUYoT, author of "Earth and Man," \&c.

\section{MURAI، MAPS.}

A series of elegant colored Maps, projected on a large scale, for the Recitation Room. consisting of a Map of the World, North and South America, Europe, Asia, Africa, etc., exhibiting the Physical Phenomena of the Globe. By Arvoly Guxot. 


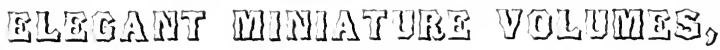

PUB LISII E J BY

\section{GOULD \& LINCOLN, . BOSTON.}

Gilt Edges and beautifully Ornamented Covers. Fourteen volumes. Price of each, 31$\}$ cents.

THE BIBLE AND TIF Closex. Edited by Rev. J. O. Chocles, D. D.

THE FAMLY ALTAR; or, the Duty, Benefits, and Hode of conducting Family Worship.

ThE FAMILY CIRClE; its Affections and Pleasures. By Rev. II. A. Graves.

THE MARRIAGE RLNG; or, How to Hake Ifome Happy. By Rev. J. A. Janes. THE CASKET OF JEWELS, for Young Christians. By JAMEs, Ldward.i, and Harras. THE ACTIVE CIRISTIAN ; from the writings of Jonn Harris, D. D.

DAILY MANNA, for Christian Pilgrims. By Rev. Barox Stow, D. D.

THE CYPRESS WREATII ; a Book of Consolation for those who Hourn. Elited by Rev. RuFus W. Griswold.

THE YOUNG COMHLXICANT; an Aid to the Right Understanding and Spiritual Improvement of the Loril's Supper.

LYRIC GEMS; a Collection of Original and Slect Sacred Poetry. Elited by Rev. S. F. SмITI.

THE HOURNER'S CHAPLET ; an Offering of Sympathy for Bereaved Friends. Selected from American Poets. Edited by Jorix KEese.

THE ATTRACTIONS OF HEAVEN. Edited by Rev. II. A. Graves.

Sets of the aboce, put up in neat boxes, convenient for packing and forming a beautiful "Miniature Library," of twelve volumes, s3.75.

THE SILENT COMforter; a Companion for the Sick Room. By Lousa Payson HoPKINS.

GOLDEN GEMS, for the Christiun. Selected from the writings of Rev. JoHn Flavel, with a Memoir "f the Author. By Rev. Joserh Barvard.

The above complete in fourteen volumes, in a neat box, $\$ 4.37 \frac{1}{2}$.

\section{ELEGANT DOCBLE MINIATCRES.}

Price of each 50 cents.

THE WEDDINC GIET ; or, the Duties and Pleasures of Domestic Life. Containing the "Marriage Ring" ant the "Family Circle." One rolume.

THE YOUNG CIIRISTIAN'S GUIDE to the Doctrines and Duties of a Religious Life. Containing "Casket of Jewels" and "Active Christian." One volume.

TIIE MOURNER COHFORTED; containing the "Cypress Wreath," by Rev. R. W. Griswold, and the "Nourner's Chaplet," by Jori KeEse. One volume.

DAILY DUTIES ; containing the "Bible and the Closet" and the "Family Altar." One volume.

THE CHRISTIAN'S PRIYATE COMPANION; containing the "Daily Manna" and the "Young Communicant." One volume.

CONSOLATION FOR THE AFFLICTED; containing the "Silent Comforter" and the "Attractions of Heaven." One volume.

Sets of the above in neat boxes, six volumes, $\$ 3.00$.

ORLANDINO : a Story of Self-Denial. By EngEworth. 15mo, eloth, gilt. 38 cents

TIE HEAVENLY FOOTMAN ; or, a Description of the Man that gets to Heaven, together with directions how to run so as to obtain. By JoHN Bexyan. 32mo, cloth, gilt. $31_{\ddagger}^{1}$ cents. 





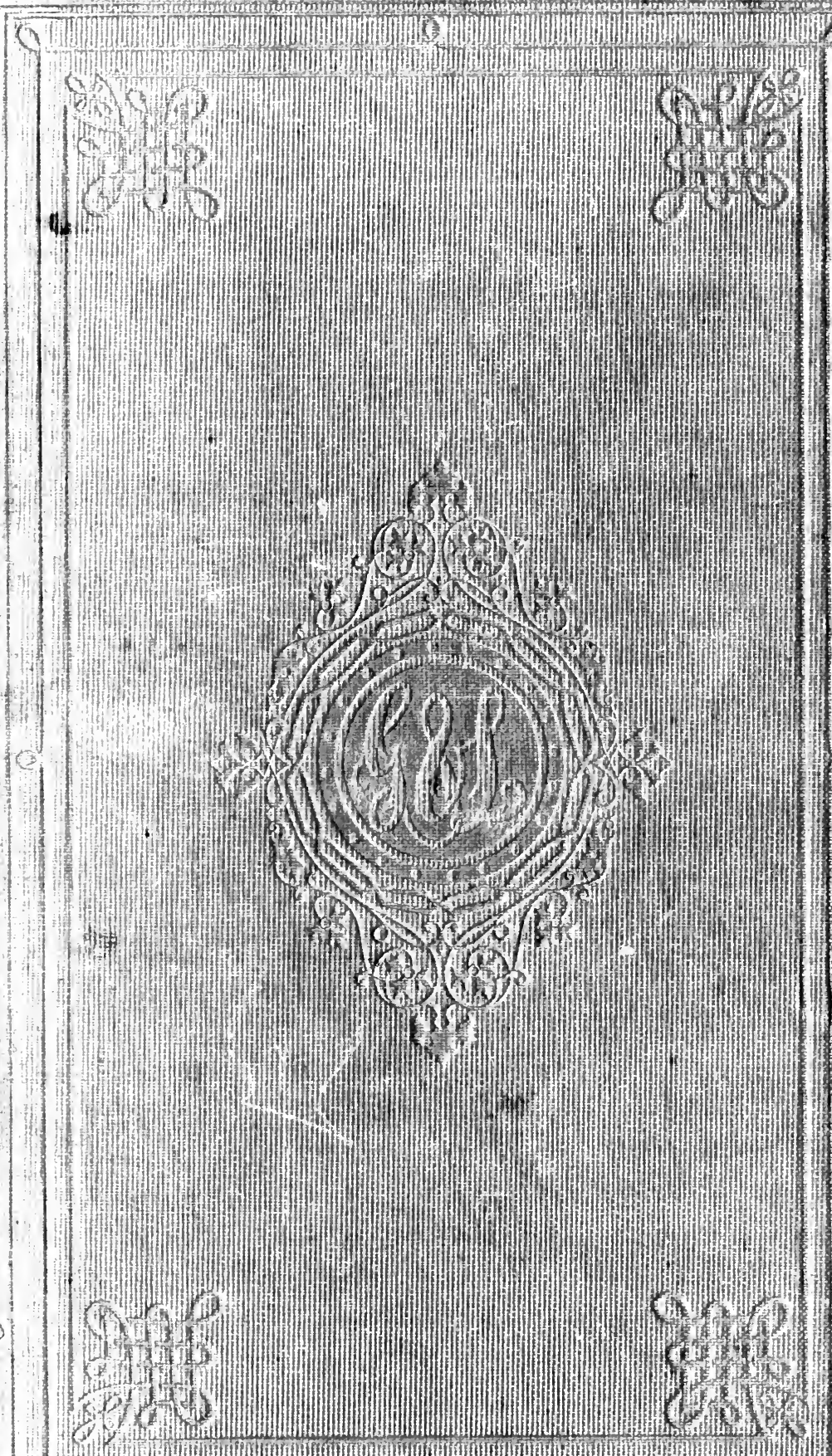

